\title{
1. CENOZOIC DIATOM BIOSTRATIGRAPHY OF THE EQUATORIAL AND SOUTHERN ATLANTIC OCEAN
}

\author{
J. Fenner, Geologisch-Paläontologisches Institut und Museum der Universität Kiel, \\ Kiel, Federal Republic of Germany
}

\section{INTRODUCTION}

During DSDP Leg 39 (October 6-December 17, 1974) seven sites were drilled in the equatorial and southern Atlantic Ocean (Figure 1, Table 1). The theme was to obtain basement data as well as sediment sequences for sedimentological and biostratigraphical studies, as a basis for an extension of the knowledge of paleomorphology and paleocirculation in the south Atlantic and paleoclimatology. Of the six sites examined for diatoms only Site 354 on the Ceará Rise, Site 356 on the southeastern São Paulo Plateau, and Site 358 in the northeastern part of the Argentine Basin did contain diatoms (Figure 2, Table 2).

Of Site 357, which seems to show continuous sedimentation from the Paleocene/Eocene boundary to Pleistocene, no samples for a diatom shore-lab study were taken because the smear-slide examination on board indicated these sediments to be barren of diatoms. This study is restricted to the late MiocenePleistocene section of Site 358, the early Oligocene section of Site 354 and the middle Eocene section of Site 356 (Figure 2). As relatively little information exists on species occurrence and their stratigraphical range, especially from Oligocene and Eocene locations, it was tried to describe all species found, to illustrate them, and to give their local stratigraphic range.

\section{METHODS}

The sediment samples collected on board during DSDP Leg 39 for a diatom shore-lab investigation were cleaned and concentrated, and the slides were prepared according to the method described in Schrader and Fenner (in press). The only difference was that the clay suspension was cleaned off six times during the concentration process.

All material was studied unfractionated. The slides were studied with a Leitz Orthoplan light microscope with apochromatic optics (objectives NPL 40×, 0,65, and NPL Oil $100 \times, 1.30$ ). All photomicrographs were made with an automatic Leitz Orthomat camera. Most specimens illustrated on the plates are shown at a magnification of $1500 \times$; for a few, a lesser magnification is indicated.

Estimates on the relative frequency of diatom species were made by using the abundance of these species observed while scanning the slides at a magnification of $1000 \times$ (objective: Oil $100 \times$. ocular $10 \times$ ):

$\mathrm{R}=$ rare occurrence, $<$ about $1 \%$ of the total diatom assemblage
$\mathrm{C}=$ common occurrence, about $1-20 \%$ of the total diatom assemblage

$F=$ frequent occurrence, about $20-40 \%$ of the total diatom assemblage

$A=$ abundant occurrence, $>$ about $40 \%$ of the total diatom assemblage

Estimates of the total abundance of diatoms, radiolarians, sponge spicules, and silicoflagellates are given in respect to the content of other siliceous fossils and clay particles in the cleaned and concentrated residue:

$\mathrm{N}=$ none found at thoroughly checking two slides

$\mathrm{R}=$ rare, $<$ about $1 \%$ of the residue

$\mathrm{C}=$ common, about $1-20 \%$ of the residue

$\mathrm{F}=$ frequent, about $20-40 \%$ of the residue

$\mathrm{A}=$ abundant, $>$ about $40 \%$ of the residue

Preservation estimates in the Eocene and Oligocene sediments were made using the relative abundance of heavily silicified diatom frustules, especially of species found from high to low latitudes, for example Coscinodiscus marginatus, Hemiaulus polycystinorum. Stephanopyxis turris, and Melosira architecturalis, combined with the relative abundance of radiolarian skeletons and sponge spicules, and with the presence of primarily weakly silicified diatom species, e.g., Hemiaulus klushnikovii. The abundance of the heavily silicified Nitzschia kerguelensis and Actinocyclus ingens helped to estimate the state of diatom preservation in the Argentine Basin sediments from late Miocene to Recent. A further criterion that can be used in nearshore-and also, as in the middle Eocene of DSDP Site 356 and the late Neogene of DSDP Site 358, even in offshore sediments, is the state of preservation of the common neritic species Melosira sulcata. This species has a long stratigraphic range: Late Cretaceous-Recent (Strelnikova, 1974; Hajós and Stradner, 1975; Schrader and Fenner, in press (a); Hustedt, 1930) and has a wide geographical distribution (Grunow, 1884; Schrader and Fenner, in press (a); Gleser and Jousé, 1974; Abbott, 1972; Simonsen, 1974).

$\mathrm{P}=$ poor preservation: many fragmented and partly dissolved frustules combined with an abundance of heavily silicified frustules.

$\mathrm{M}=$ moderate preservation: heavily silicified diatoms are not dominant. Melosira sulcata specimens show beginning dissolution at the margin.

$G=$ good preservation: presence of diatom frustules known as primarily weakly silicified. Only a few broken and partly dissolved frustules of Melosira sulcata. 
353 VEMA
FOCTURE
ZONE

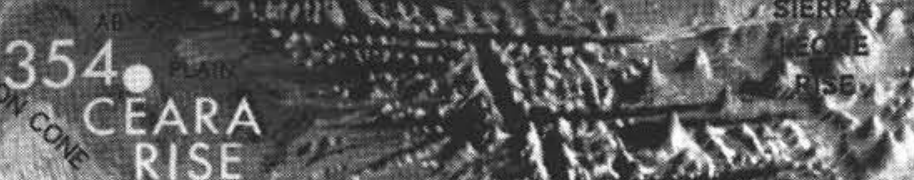

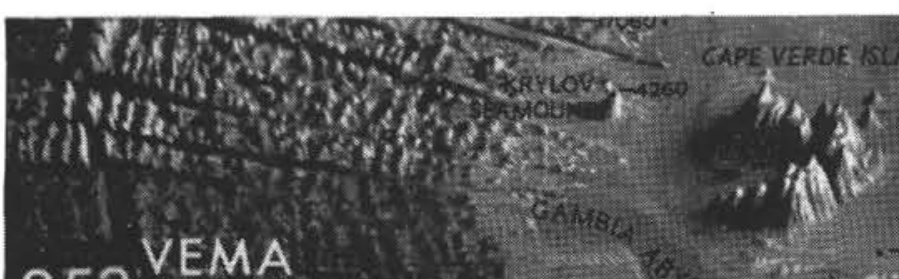

Figure 1. Physiographic chart of the South Atlantic (from Heezen and Tharp, 1961; copyright National Geographic) with the locations of the sites drilled and cored during DSDP Leg 39. 
TABLE 1

Site locations and Water Depths of Sites Containing Diatoms

\begin{tabular}{cccc} 
Site & Latitude & Longitude & $\begin{array}{c}\text { Water Depth } \\
(\mathrm{m})\end{array}$ \\
\hline 354 & $05^{\circ} 53.95^{\prime} \mathrm{N}$ & $44^{\circ} 11.78^{\prime} \mathrm{W}$ & 4052 \\
356 & $28^{\circ} 17.22^{\prime} \mathrm{S}$ & $41^{\circ} 05.28^{\prime} \mathrm{W}$ & 3203 \\
358 & $37^{\circ} 39.31^{\prime} \mathrm{S}$ & $35^{\circ} 57.82^{\prime} \mathrm{W}$ & 5000 \\
\hline
\end{tabular}

\section{LATE NEOGENE DIATOM STRATIGRAPHY OF THE SOUTHERN OCEAN}

For the Neogene of the south Pacific Ocean a diatom stratigraphy from Late Oligocene-Pleistocene was established by McCollum (1975). He correlated the upper part: late Miocene-Pleistocene (Magnetic Epoch 5-Brunhes) to paleomagnetically dated piston cores collected by U.S.N.S. Elantin (USARP). This late Neogene diatom zonation was adopted by Gombos (in press) for the sediments of the south Atlantic and was also used by Schrader (1976) for the southeastern Pacific. This Neogene diatom zonation of McCollum (1975) is applicable to both the Atlantic and the Pacific sector of the Southern Ocean, because of the Circumantarctic Current, which existed since early Oligocene and has caused a homogeneous plankton population (Baker, 1954; Mackintosh, 1964). In the Argentine Basin this same zonation (Figures 3,4) can be used (compare Gombos, in press; and this study).

A tentative correlation to earlier diatom-biostratigraphic works (Jousé et al., 1963; Donahue, 1970; Abbott, 1972; Jousé and Petrushevskaya, 1974) in the Southern Ocean (Figure 4) was compiled from McCollum (1975), Jousé and Petrushevskaya (1974), and Abbott (1972). A correlation to equatorial and north Pacific Neogene diatom zones can be found in McCollum (1975, p. 534, fig. 12). According to Saito (1969), Kennett and Watkins (1972), and Berggren (1972) the Miocene/Pliocene boundary was placed at the top of Magnetic Epoch 5 at 5.0 m.y.B.P. (Theyer and Hammond, 1974b), and thus falls into the upper part of the Denticula hustedtii Partial Range Zone of McCollum (1975). The Pliocene/Pleistocene boundary was placed in the lower part of the Olduvai Event of the Matuyama Reversed Epoch (1.85 m.y.B.P.) by Theyer and Hammond (1974b), in accordance with Burckle (1972), Cita (1972), and Hays and Berggren (1971), that is within the Rhizosolenia barboi-Nitzschia kerguelensis Zone of McCollum (1975). Both boundaries have not yet been defined by diatoms.

The ranges of the diatoms observed are consistent with those reported by former stratigraphic works in the Neogene (Burckle, 1972; Muhina, 1969; Kanaya, 1971; McCollum, 1975; Gombos, in press; Schrader, in press), except for single occurrences of Denticula hustedtii in Pleistocene sediments, which species should be extinct at the end of Miocene or at earliest Pliocene (McCollum, 1975; Schrader, in press). Single specimens of Hemidiscus karstenii were found in Pleistocene sediments, probably reworked from the early Miocene (compare Schrader, 1976). But besides these single findings, reworking from older sediments seems to have no severe influence to the examined sediments, as none of the Denticula species typical for and common during the middle Miocene (compare Schrader, 1976) were found, nor older species.

\section{PALEOGENE DIATOM STRATIGRAPHY}

\section{Previous Work}

Paleogene diatoms have been described from wellknown land sections: as Mors, Denmark (early Eocene) by Heiberg (1863), Grunow (1866, 1884), Kitton (1870/71), Prinz (1881), Prinz and Van Ermengem (1883), Van Ermengem (1885), Van Heurck (18801885), Stolley (1899), Tsumura (1963), and Benda (1972); from localities in north Germany, early Eocene sediments (Schulz, 1927) and Hustedt in Wetzel (1935) described diatoms from a section near Heiligenhafen (late Eocene) and Benda (1965) from the Tarras of Fehmarn (upper early Eocene); from middle Eocene localities in the Soviet Union, in west Siberia and west Kazakstan and late Eocene localities in west Siberia and the Ukraine Proschkina-Lavrenko (1949-1951), Jousé (1951a, 1955), Rudkevic et al. (1957), Krotov and Shibkova (1959, 1961), Rubina and Drosnes (1961), Sheshukova-Poretzkaya and Gleser (1964), Paramonova (1965), Gleser (1966, 1968, 1969, 1970), and Jousé and Gleser (1974). The late Eocene diatoms of the Kreyenhagen shale were described by Hanna (1931). The famous Oamaru diatomite (late Eocene) was studied by many diatomists: Greville (1861-1866), Grove and Sturt (1886-1889), Brun (1890-1896), Forti (1913), Tsumura (1963), Hanna and Brigger (1964). Most of these scientists also dealt with the Barbados deposits (late Eocene-early Oligocene). All these studies furnished valuable taxonomic information.

Emphasis was put on stratigraphical work only later on, as in Benda (1972) and in the study of Kanaya (1957), who gave the observed ranges of diatoms found in the early late Eocene sedimentary sequence of the Kellogg and "Sidney" shales, near Mt. Diablo, California, and who also made a semi-quantitative diatom analysis. The late Eocene Californian diatom shales were correlated to the planktonic foraminiferal zones of Blow (1969) and the planktonic foraminiferal datum planes of Berggren (1969) by Kanaya and Koizumi (1970). The Kellogg and Sidney shales fall into the lower part of P15 of Blow (1969) and the Kreyenhagen shale is practically identical with P16 of Blow (1969).

Hajós (1976) gave a detailed record of the late Eocene-early Oligocene diatoms of the southwest Pacific: DSDP Leg 29, Sites 281, 280A, and 283 can be correlated to the calcareous nannofossil zones of Edwards and Perch-Nielsen (1975, tables 7 and 10) and the silicoflagellate zonation of Perch-Nielsen (1975, tables 5, 7, and 8).

Gombos (in press) made a study on late Eocene, early and late Oligocene diatoms of the Falkland Plateau (DSDP Leg 36, Site 327; Site 328, Core 4; and Site 328B, Cores 3-5). As no calcareous nannofossils were observed in these cores only a correlation of the zones of Gombos (in press) to the silicoflagellate- and radiolarian zonation was possible. 


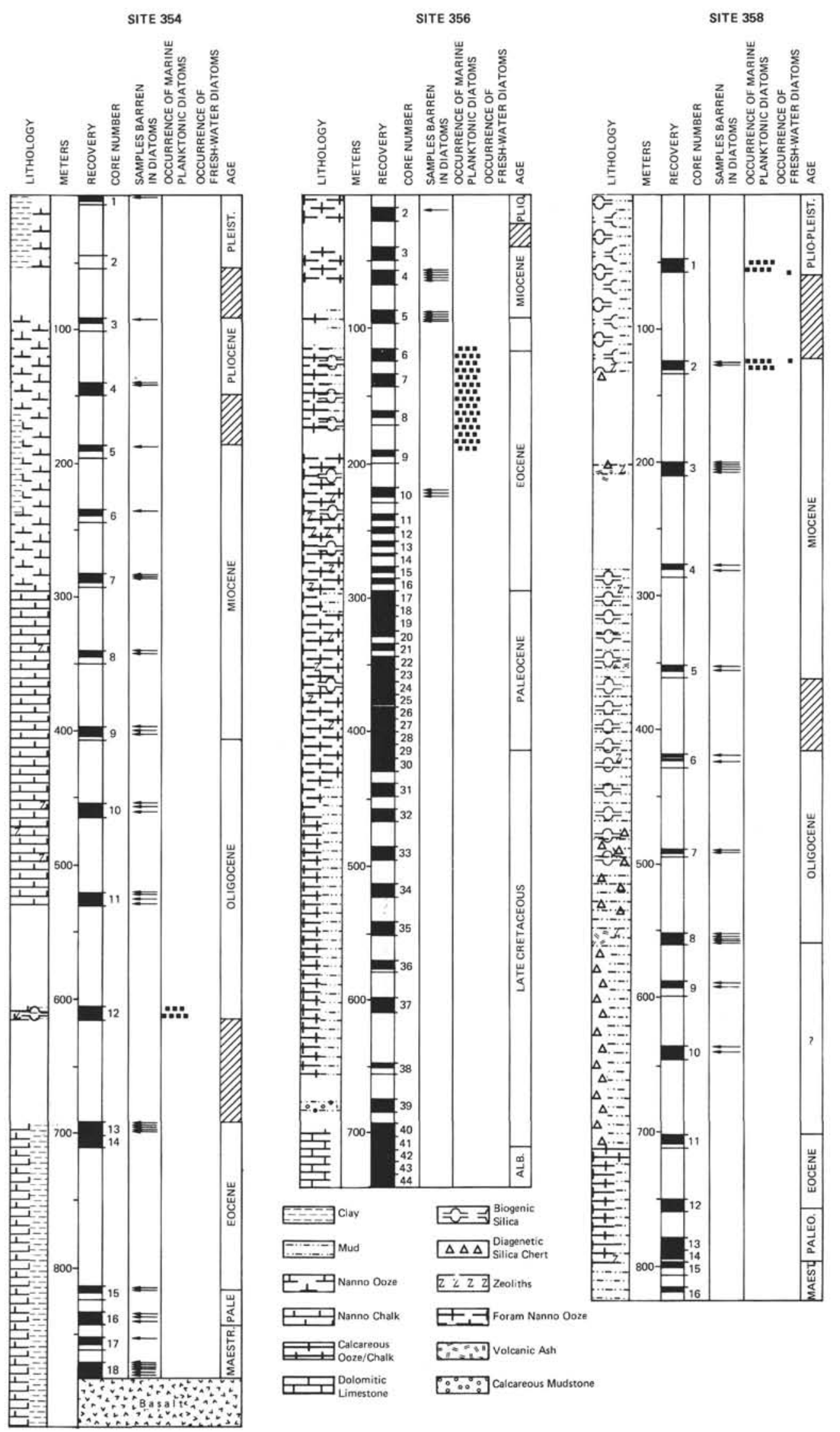

Figure 2. Cored intervals of the Sites 354, 356, and 358 and their diatom content. Ages taken from the report of the shipboard scientific party, DSDP Leg 39 (this volume). 
TABLE 2

List of Samples (Interval in $\mathrm{cm}$ )

Barren of Diatoms

Hole 353

2-2 30-31

$3-2 \quad 30-31$

3-5 30-31

Hole 353A

$1-2 \quad 60-61$

Site 354

1-2 30-31

3-2 30-31

3-2 30-31

4-1 30-31

4-2 30-31

5-2 30-31

6-2 40-41

$7-1 \quad 94-95$

$7-2 \quad 32-33$

$7-3 \quad 29-29$

$7-4 \quad 30-31$

$7-\mathrm{CC}$

8-1 30-31

8-3 22-23

9-1 38-39

9-3 25-26

9-5 24-25

10-1 5-6

$10-3 \quad 15-16$

$10-5 \quad 59-60$

11-1 33-34

11-2 71-72

11-3 23-24

11-4 30-31

11-5 5-6

11-6 11-12

13-1 36-37

13-2 20-21

13-3 29-30

13-4 22-23

13-5 31-32

13-6 30-31

14-1 20-21

14-2 67-68

14-3 44-45

14-4 26-27

14-5 22-23

14-6 52-53

$15-2 \quad 42-43$

15-3 30-31

$16-2$ 10-11

16-3 39-40

$16-5 \quad 19-20$

17-2 10-11

18-1 20-21

18-2 33-34

$18-3 \quad 67-68$

18-4 6-7

18-5 104-105

18-6 112-113

Site 355

\begin{tabular}{ll}
$1-1$ & $30-31$ \\
$1-5$ & $30-31$ \\
$2-2$ & $34-35$ \\
$2-5$ & $30-31$ \\
$3-2$ & $30-31$ \\
$5-1$ & $45-46$ \\
\hline
\end{tabular}

TABLE 2 - Continued

$\begin{array}{ll}5-2 & 50-51 \\ 5-3 & 30-31\end{array}$

Hole 356

2-2 30-31

4-1 40-41

4-2 30-31

4-3 30-31

4-4 30-31

4-5 30-31

4-6 30-31

5-2 10-11

5-3 30-31

5-4 30-31

5-5 30-31

5-6 30-31

$10-2 \quad 30-31$

10-3 26-27

$10-4 \quad 30-31$

Hole 356A

$\begin{array}{ll}1-4 & 138-139 \\ 1-5 & 120-121 \\ 1-6 & 120-121 \\ 2-2 & 120-121 \\ 2-6 & 93-94^{\mathrm{a}}\end{array}$

Site 358

2-2 30-31

2-3 30-31

3-2 40-41

3-3 40-41

3-4 40-41

3-5 40-42

3-6 40-41

4-2 80-81

4-4 30-31

5-1 66-67

5-2 120-121

6-1 $\quad 15-16$

6-3 92-93

$7-1 \quad 80-81$

7-2 85-86

8-1 105-106

8-2 67-68

$8-3 \quad 16-17$

8-4 128-129

8-5 128-129

$8-6 \quad 87-88$

9-2 107-108

9-3 72-73

10-1 56-57

10-3 105-106

Site 359

$\begin{array}{ll}1-4 & 110-111 \\ 2-1 & 110-111 \\ 2-6 & 143-144 \\ 3-1 & 110-111^{a} \\ 3-2 & 110-111 \\ 3-3 & 18-19 \\ 3-4 & 71-72 \\ 3-5 & 38-39 \\ 4-1 & 117-118\end{array}$

${ }^{a}$ Rare occurrence of diatom fragments, of non age-diagnostic species. 


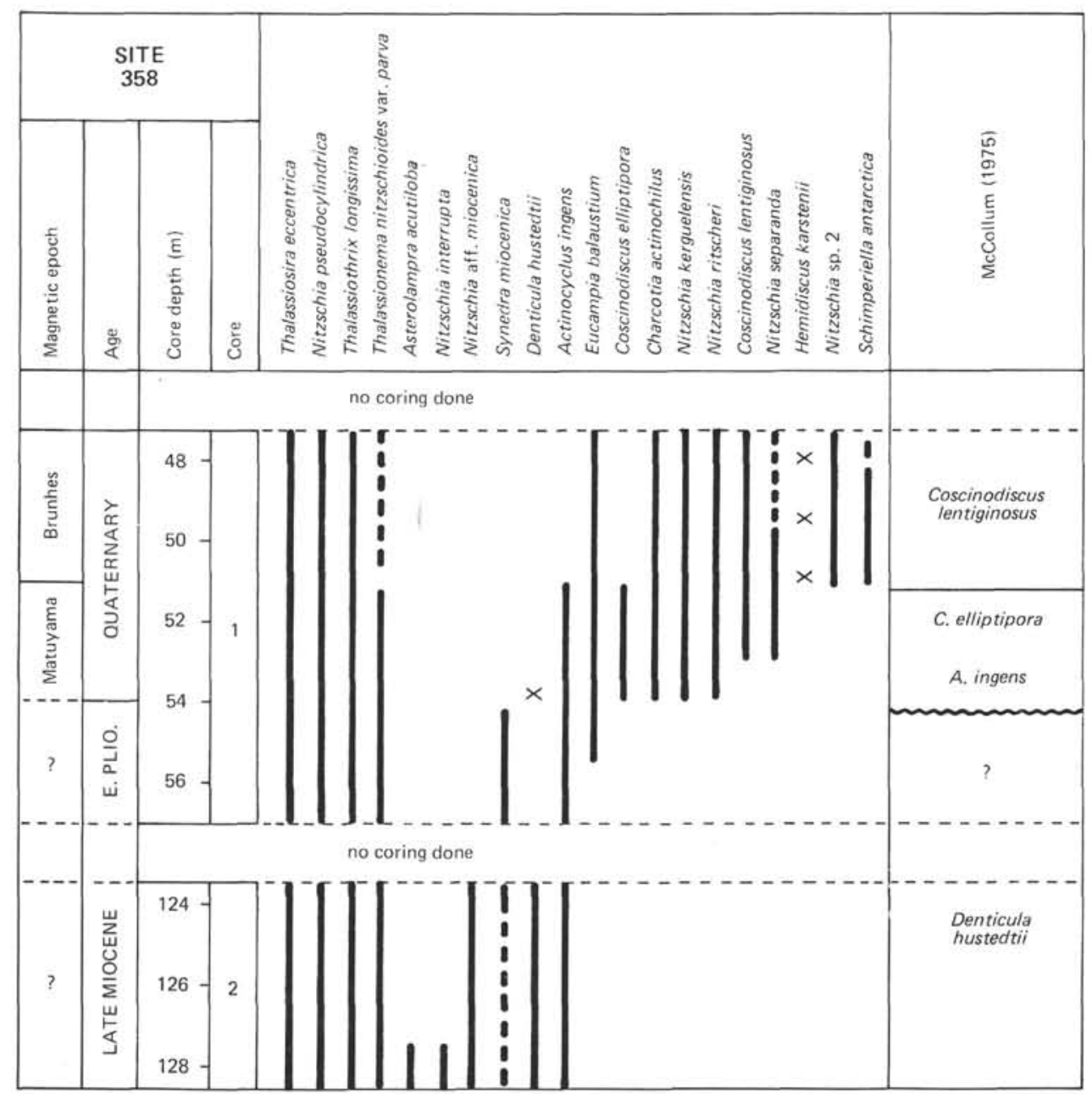

$\mathrm{X}$ rare occurrence of species, interpreted to be reworked

Figure 3. Ranges of Neogene diatoms of Site 358.

Jousé (1973) gave a preliminary Paleogene diatom zonation for the tropical Pacific and Atlantic Ocean from late Eocene to late Oligocene, in which she has included the Oceanic Formation of Barbados, piston cores, and DSDP drill cores.

A late Oligocene, local diatom zone was established in Site 278 of DSDP Leg 29 by Schrader (1976) for the Southern Ocean, which he tied to the calcareous nannofossil zonation. Schrader defined the Oligocene/Miocene boundary (22.5 m.y.B.P., Berggren, 1972) by the top of his Pyxilla species zone, where all Pyrgupyxis species disappear. That is the top of the Pyxilla prolongata Partial Range Zone of Gombos (in press), and falls into the uppermost part of the Coscinodiscus vigilans-Craspedodiscus coscinodiscus Zone of Jousé (1973). The late Oligocene Pyxilla species Zone established on Site 278 (DSDP Leg 29) by Schrader (1976) is not correlative to the Pyrgupyxis prolongata Zone of DSDP Leg 28, Site 274 (McCollum, 1975), for which also the other microfossil groups give an early Oligocene age (Ciesielski, 1975, p. 645; Gombos, in press). A late Eocene-late Oligocene diatom zonation was established by Schrader and Fenner (in press [a]), but with a hiatus from the top of the Coscinodiscus oblongus Partial Range Zone (upper late Eocene) to the Sceptroneis pupa Partial Range Zone (lower late Oligocene). This zonation was tied to the silicoflagellate zonation (Müller, in press) and the nannofossil zonation given by Martini (in press).

The late Eocene-Oligocene zonation for the tropical areas of Jousé (1973) was adopted in this study. Further investigations on more complete sections will certainly make possible a more detailed zonation.

The middle Eocene age of Sections 356-6-1 to 356-9-2 has been drawn from other microfossil groups: calcareous nannofossils (Perch-Nielsen, this volume) and planktonic foraminifera (Boersma, this volume).

\section{Early Oligocene and Middle Eocene Diatom Zones}

\section{Early Oligocene}

According to the frequent to common occurrence of Coscinodiscus superbus (Synonym: Cestodiscus pulchellus) the sediments of Site 354, Core 12 represent a part of the early Oligocene Cestodiscus pulchellus Zone of Jousé (1973), established for the equatorial Atlantic and Pacific. No subzones were defined. The early Oligocene age is in good accordance with the 


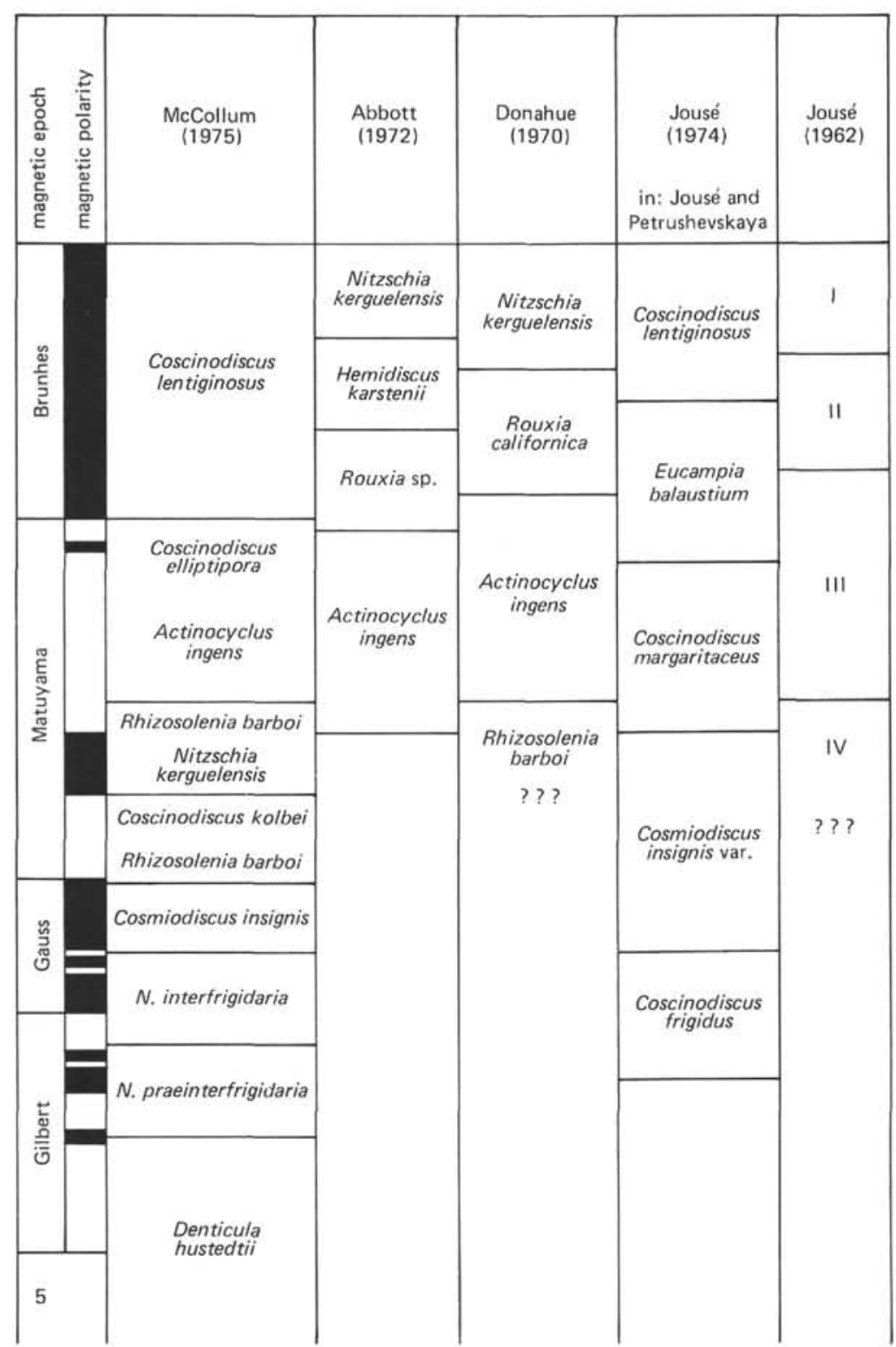

Figure 4. Correlation of the locally established late Neogene diatom zonations within the Southern Ocean; taken from McCollum (1975), Jouse and Petrushevskaya (1974), Abbott (1972).

results from the calcareous nannofossils: Ericsonia subdisticha Zone, planktonic foraminifera, and radiolarians (Perch-Nielsen, Boersma, Dinkelman, this volume).

The found diatom assemblage is characterized by the common occurrence of: Coscinodiscus superbus, $C$. oligocenicus, Asterolampra marylandica, C. excavatus var. quadriocellata, $C$. excavatus var. semilunaris, $C$. excavatus var. tuberosa, A. aff. grevillei, Xanthiopyxis structuralis, Podosira polita, C. marginatus, C. radiatus, and Synedra miocenica. Besides these dominant elements further characteristic species occurred: Asteromphalus oligocenicus, Brightwellia hyperborea, Campyloneis grevillei, Campylosira sp., Coscinodiscus bulliens, $C$. sellatus, Hemiaulus subacutus, $H$. klushnikovii, $H$. polycystinorum, $H$. polymorphus var. frigida, Kozloviella sp., Melosira architecturalis, $M$. sulcata, Raphoneis sp., Rhizosolenia hebetata var. subacuta, Sceptoneis tenue, Thalassiothrix longissima, Triceratium condecorum, Trinacria subcapitata, Xanthiopyxis acrolophora, and $X$. ovalis. Species of the genera Pterotheca, Pyxilla, and Pyrgupyxis are completely missing.

These described floral characteristics show much similarity to the early Oligocene sedimentary sequence of the upper section of the Oceanic Formation of Barbados. Especially the dominance of Coscinodiscus superbus, and $C$. excavatus with its varieties, which all are only reported from low latitudes, characterizes this assemblage as tropical. 
Middle Eocene

The middle Eocene age for Cores 6-9 of Site 356 is given by calcareous nannofossils, radiolarians, and planktonic foraminifers (Perch-Nielsen, Dinkelman, Boersma, this volume).

As this 79-meter mighty middle Eocene sedimentary sequence was not continuously c red, no zones could be defined. The characteristic floral changes, which were found, just separate the cores so that the boundaries will lie somewhere in the coring gap. Because of this the last and new occurrences of species of diatoms are described separately for Cores $6,7,8$, and 9. It was not tried to establish zones.

Core 6: (age: P11/P12; Boersma, this volume). This core is characterized by the common occurrence of Hemiaulus polycystinorum, Riedelia alata, $R$. sublevata, and by the presence of Hemiaulus proteus, Triceratium davidsonianum, Coscinodiscus bulliens and Monobranchia unicornuta. T. schulzii var. quadrilobata is completely missing and $T$. schulzii is found only in single specimens. Both are characteristic for the sediments of Cores 7, 8, and 9.

Core 7: (age: P10/P11; Boersma, this volume). This core is characterized by a dominance of Triceratium schulzii, $T$. inconspicuum, $T$. barbadense, and the occurrence of $T$. labyrinthaeum.

Cores 8 and 9: (ages: P10-P11 and P8-P10; Boersma, this volume). Within these two cores the same species of Triceratium are dominant as in Core 7, but Hemiaulus klushnikovii, Pterotheca gracillima, Riedelia claviger, $R$. tenuicornis, Brightwellia hyperborea, Coscinodiscus tuberculatus var. atlantica, and Melosira westii, which are present in Cores 6 and 7 are missing. New species, Craspedodiscus aff. elegans, Hemiaulus incisus, and Triceratium acutangulum, and further, Rylandsia biradiata and Rutilaria sp. are present.

The whole middle Eocene sequence from Core 9, Section 2 to the top of Core 6 is characterized by the common occurrence of Hemiaulus polycystinorum var. mesolepta, Ethmodiscus sp., Melosira architecturalis, Pseudopodosira bella, and Coscinodiscus oblongus.

Further species occurring in all these cores are Coscinodiscus praenitidus, Xanthiopyxis structuralis, Sceptroneis tenue, $S$. pesplanus, $S$. ligulatus, Riedelia altar, $R$. borealis, Pyrgupyxis caput avis, P. johnsoniana, $P$. gracilis, Pterotheca aculeifera, Pseudorutilaria monomembranacea, Hemiaulus weissii, Eunotogramma weissii var. producta, and Brightwellia coronata.

Only a few other middle Eocene diatom-containing sequences have been described: DSDP Site 13, Core 3 from the equatorial Atlantic (Gleser and Jousé, 1974) and localities in West Siberia and West Kazakstan (Gleser and Jousé, 1974; Gleser, 1969; Paramonova, 1964; Rubina and Drosnes, 1961). A comparison with these localities and with early Eocene localities: Mors (Grunow, 1884; Benda, 1972); Northern Germany (Benda, 1965); the London Clay (Shrubsole and Kitton, 1881); the Volga district and west Siberia (Gleser, 1966; Krotov and Shibkova, 1961; Paramonova, 1964; Gleser and Jousé, 1974); and with late Eocene localities: California (Hanna, 1931; Kanaya, 1957); Barbados
(Greville, 1861-1866; Grunow, 1884; Hanna and Brigger, 1964, 1965; Jousé, 1974); equatorial Pacific near Tuamotu Islands (Jousé, 1968); Southwest Pacific (Hajós, 1976); Falkland Plateau (Gombos, in press); Oamaru (Grove and Sturt, 1886-1889; Brun, 1891, 1890-1896; Schmidt, 1874-; Forti, 1909; Tsumura, 1963); Ukraine (Gleser et al., 1965; Gleser and Sheshukova-Poretzkaya, 1968, 1969; Gleser, 1970; West Kazakstan (Gleser, 196y); west Siberia (Gleser, 1966; Gleser, 1970; Krotov and Shibkova, 1961; Paramonova, 1964); east Slope of the Ural (Krotov and Shibkova, 1961); Norwegian Sea (Schrader and Fenner, in press $\mathrm{a}, \mathrm{b})$ was done. This comparison shows that most species found have a wide geographical distribution. For example: Pterotheca aculeifera, Pyrgupyxis johnsoniana, P. gracilis, Melosira architecturalis, Coscinodiscus tuberculatus var. atlantica, Hemiaulus polycystinorum were uprooted from the extreme high to the low latitudes. Whereas the commonly occurring Hemiaulus polycystinorum var. mesolepta, Triceratium schulzii, Coscinodiscus oblongus, and Triceratium barbadense seem to be confined to the tropical/subtropical regions (Fenner, in press). From the admittedly still fragmentary knowledge this assemblage is interpreted to indicate tropical/subtropical surface waters.

\section{DIATOMS AT EACH SITE}

All samples, routinely taken for diatom analysis from the cored sections of all sites of DSDP Leg 39, were looked through. But only in Paleogene samples of Sites 354 and 356 and in Neogene samples of Site 358 were diatoms found; compare list of diatom-barren samples (Table 2). Only these three sites will be described and discussed here concerning their diatom-content. The different length of the tables listing the occurrence of diatoms is not due to more or less intense observation but represents the different diversity found.

\section{Site 354 (Figure 5, Tables 2, 3)}

This Site is located at a basement high, the Ceará Rise, which is overlain by about 1 kilometer of sediments. It lies 150 miles (about $240 \mathrm{~km}$ ) east of the Amazon Cone in the western equatorial Atlantic (Figure 1, Table 1). Diatoms were found only in the Core 12 early Oligocene, where they constitute $30-40 \%$ of the sediment (zeolithic diatomaceous nannochalk). No diatoms occur below the hiatus found in Core 12, CC.

In all samples the preservation of diatoms was moderately good to poor. In Sample 354-12-4, 13-14 $\mathrm{cm}$, which has a poorly preserved diatom flora, single specimens of Liostephania stages were found. Diatom abundance was common to frequent.

Distinctive of this core are finely laminated bands (1$2 \mathrm{~cm}$ thick), with fine black pyrite containing layers alternating with white laminae ( $\sim \mathrm{mm}$ thick). These dark laminated bands have an overall composition similar to the surrounding greenish gray, zeolithic, diatomaceous chalk, except for the presence of pyrite. The pyrite together with the high diatom content and 


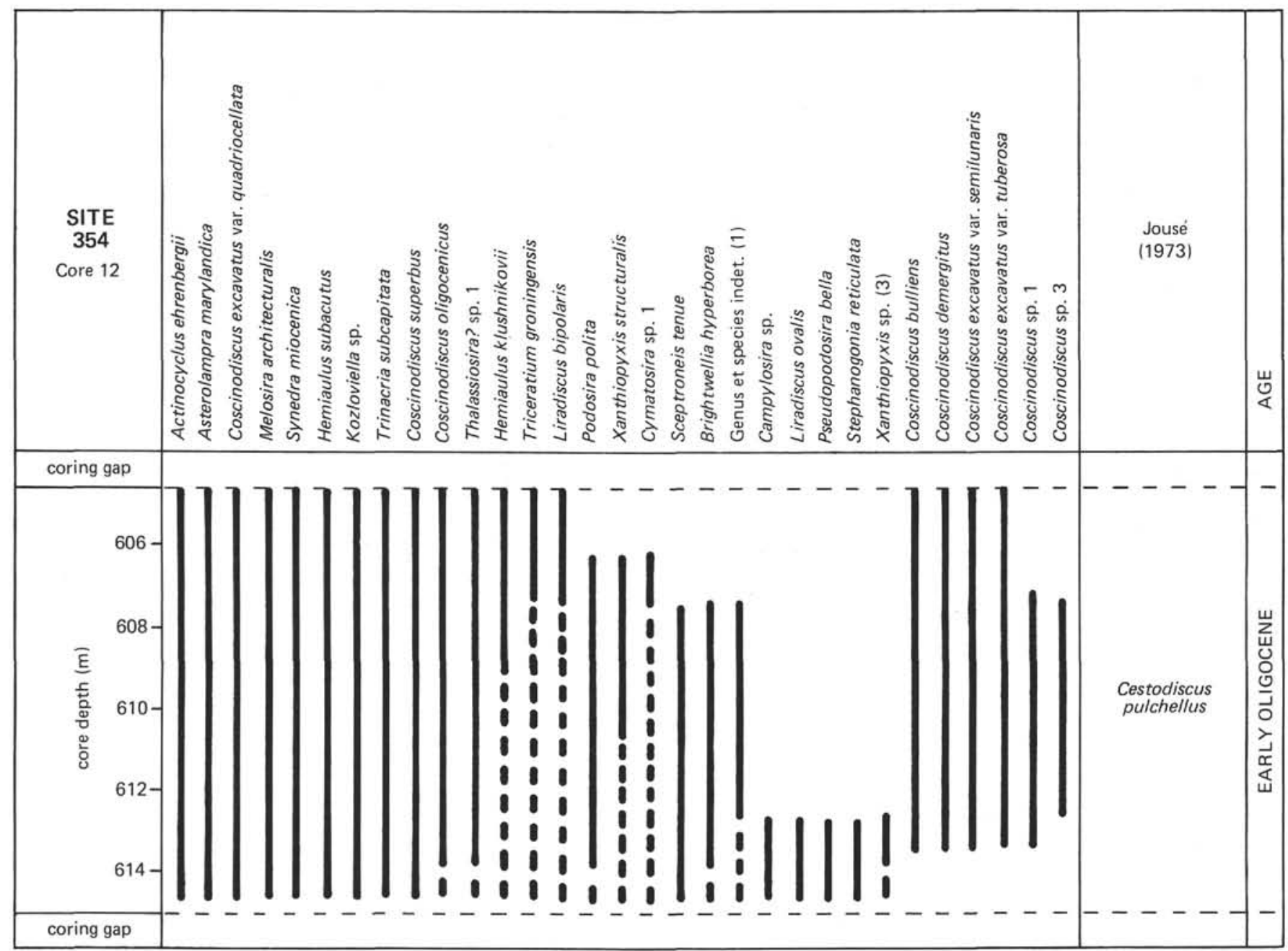

Figure 5. Ranges of early Oligocene diatoms of Site 354.

the fish teeth, found in these sediments by Boersma (this volume) might indicate an increased primary production. Just beneath these laminated bands intensely burrowed dark green-brown zones are often present.

Samples as well from the laminated bands (Samples $354-12-1$, 49-50 cm; 354-12-4, 13-14 cm), from the intensely burrowed zones (Sample 354-12-5, 82-83 cm), as also from the surrounding moderately burrowed, diatomaceous chalk (Samples 354-12-2, 14-15 cm; 354$12-3,2-3 \mathrm{~cm} ; 354-12-6,40-41 \mathrm{~cm}$; and 354-12-6, 137-138 $\mathrm{cm})$ were looked through. But they all did show no distinctive differences in the dominance, diversity, or species composition of planktonic marine diatoms which would indicate an alteration in the surface water characteristics. So, maybe, changes in the deeper water (circulation and CCD level or rate of sedimentation) could be responsible for these lithologic changes.

The common occurrence of the index-species Coscinodiscus superbus and $C$. excavatus var. quadriocellata places the whole section between Samples 354-12-1, 49-50 cm, and 354-12-6, 137-138 cm, into the early Oligocene Cestodiscus pulchellus Zone of Jousé (1973), according to the diatom zonation given by her for the tropical areas of the Pacific and Atlantic
Oceans (Jousé, 1973). Further, this flora seems to represent offshore habitat, as species of the genera Diploneis and Mastogloia, which were interpreted as benthic, occurred only extremely rarely, and other species, known as benthic, were completely missing.

\section{Site 356 (Figure 6, Tables 2, 4)}

Site 356 is located on the southwestern edge of the São Paulo Plateau (Figure 1, Table 1), 3175 meters below sea level, between the east-west basement ridge as its southern margin and the zone of diapirs starting northward (see Leyden and Nunes, 1974; Leyden et al., 1976).

Diatoms were only found in Cores 5 through $9(0-93$ $\mathrm{m}$ core depth) an orange gray-bluish to gray-greenish gray, foram and nanno ooze, zeolithic in the marly ooze horizons. They are extremely rare and very poorly preserved in Core 5 due to diagenesis. The few diatoms observed do not allow an age-assignment. Radiolaria, foraminifers, and calcareous nannofossils date this core and the uppermost part of Core 6 as early Miocene (this volume).

Below a hiatus in Core 6, Section 1, Cores 6 through 10 consist of greenish gray, siliceous-calcareous ooze, containing a few dark layers, which are composed of 
TABLE 3

Early Oligocene Diatom Species of Site 354

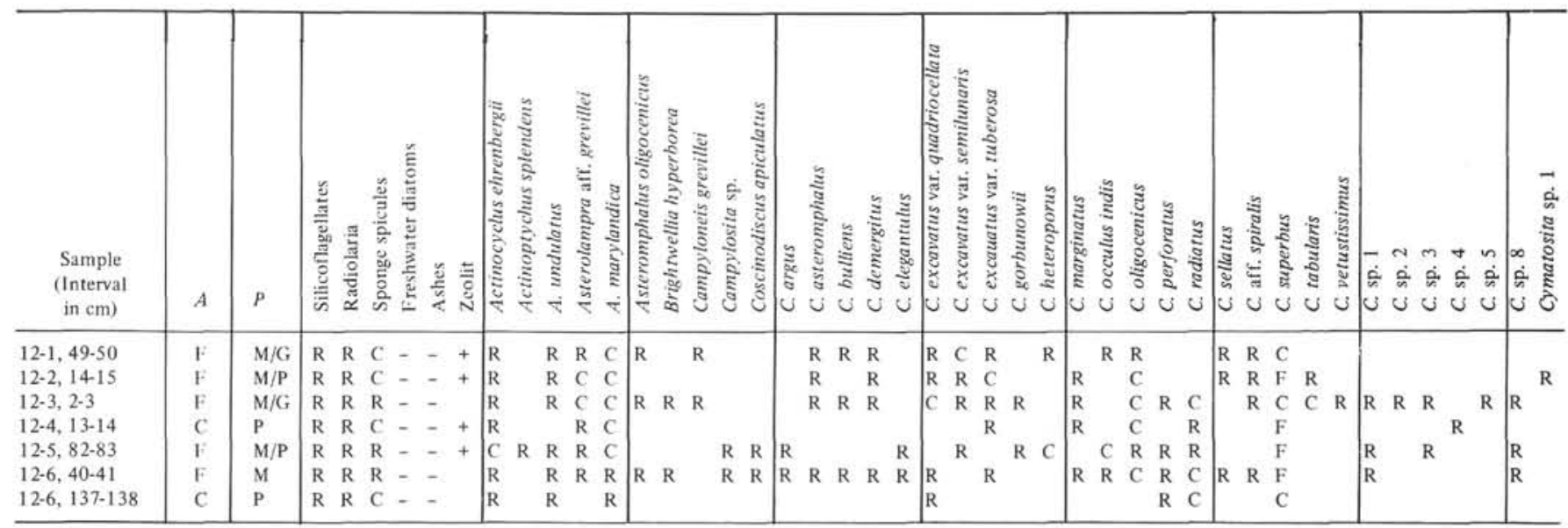

predominantly siliceous biogenic material. Zeoliths occur as a minor constituent. Diatoms were observed from Core 6, Section 2 to Core 9, Section 2, commonfrequent with a moderate to poor preservation.

For the sediments between Samples 356-6-2, 30-31 $\mathrm{cm}$, and $356-9-2,30-31 \mathrm{~cm}$, a middle Eocene age is given by calcareous nannofossils (Perch-Nielsen, this volume) and planktonic foraminifers (Boersma, this volume) and was adopted in this study. The diatoms observed in this sequence made a differentiation of Core 6 from Core 7 and from Cores 8 and 9, 10 possible separated from each other by coring gaps.

In the lower part of Core 9 and from Core 10 down, diatoms are lacking because of diagenetic solution. The dissolution of diatom shells is accompanied by an increased occurrence of zeoliths. Liostephania-stages of Asteromphalus spp., Asterolampra spp., Coscinodiscus tabularis?, and unknown species occur rarely throughout the diatom-containing middle Eocene section. These internal molds indicate starting diagenesis. As this assemblage was dominated by cosmopolitan- and low-latitude diatom species, this assemblage was interpreted as tropical-subtropical.

The diatom flora represents typical offshore conditions, as species which might be interpreted as benthic: as some species of the genera Auliscus, Arachnoidiscus, Raphoneis and perhaps Eunotogramma, occur only with extreme scarcity (less than $0.5 \%$ of the total diatom assemblage), and certainly are allochthonous. A suggestion for the middle Eocene water depth is given by the nannofossils. Their great diversity and the presence of Zygrhablithus bijugatus, which dissolves at a water depth greater than 1000 meters, indicates, according to Perch-Nielsen (this volume), a water depth of not greater than 1000 meters.

\section{Site 358, Northeastern Argentine Basin}

(Figure 3, Tables 2, 5)

Eogene diatoms were found in only one of the sites drilled and cored during DSDP Leg 39 , Site 358. It is located in the northeastern Argentine Basin at a water depth of 4962 meters, about 160 kilometers east of Site 331 (DSDP Leg 36). Diatoms were found between
Sample 1-1, 30-31 cm, and Sample 2-4, 30-31 cm. For number and location of samples barren in diatoms, see Table 2. Radiolaria were also found in Cores 4-6 and 8. Cores 1 and 2 consist of a low consolidated, greenish gray mud, rich in pyrite, with a large biogenic siliceous component (50-60\% clay, $25-50 \%$ siliceous fossils) indicating a deposition below the CCD. The high amount of clay might be explained by a deposition out of a bottom nepheloid suspension, which can be assumed because of the location of this site under the diffused eastern (south flowing) arm of the Argentine Bottom Gyre (Wüst, 1957; Le Pichon et al., 1971), while the surface core of Site 331 consists of silty mud (Barker and Dalziel, in press) according to the more vigorous current regime expected further to the west. At the base of Core 2 at 152 meters, core depth, a minor subbottom reflector was found. Below this depth the diatom skeletons are dissolved and a slight decrease in salinity from $35.2 \%$ to $34 \%$ and a slight increase of the $p \mathrm{H}$ from 7.5 to 7.7 (values interpolated) is found.

Diatoms occurring in Cores 1 and 2 are generally rare and moderately to poorly preserved. Only in Core 1 , Sections 1-3, where the diatoms were found commonly to frequently, was the preservation moderate to good. Sample $358-1-1,30-31 \mathrm{~cm}$, to Sample $358-1-2,30-31 \mathrm{~cm}$, has been placed into the Pleistocene Coscinodiscus lentiginosus Zone of McCollum (1975), the base of which is defined by the last occurrence of Coscinodiscus elliptipora and Actinocyclus ingens.

Sample 358-1-3, 30-31 cm, to Sample 358-1-5, 30-31 $\mathrm{cm}$, was determined as Coscinodiscus elliptiporaActinocyclus ingens Zone of Pleistocene age according to McCollum (1975). Sample $358-1-6,30-31 \mathrm{~cm}$ is characterized by Eucampia balaustium and Actinocyclus ingens as well as the Miocene species Synedra miocenica. An exact age determination of this part is not possible. It is supposed to be of early Pliocene age as the typical late Miocene Denticula species are missing and the typical Pleistocene and late Pliocene species Coscinodiscus lentiginosus and Nitzschia kerguelensis (McCollum, 1975) appear only in the samples above. But the typical species of the early 


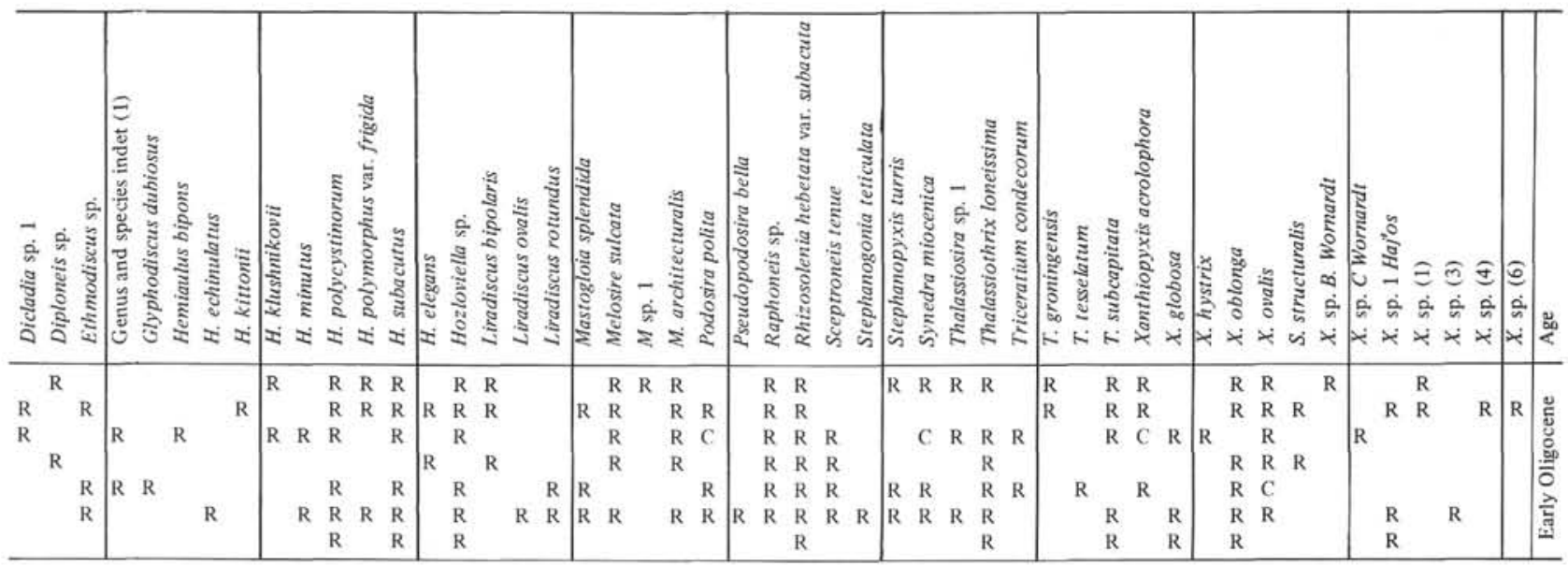

Pliocene Nitzschia praeinterfrigidaria or $N$. interfrigidaria Zones of McCollum (1975) (compare McCollum, 1975; Schrader, 1976) were not found. So this age suggestion is very tentative.

The unconformity between early Pliocene and Pleistocene (between Samples 358-1-6, 30-31 cm, and $358-1-5,30-31 \mathrm{~cm}$, might be due to more active Antarctic Bottom Water flow at the end of Pliocene or during early Pleistocene, eroding at this part of the Argentine Basin or at least hindering sedimentation. This unconformity covers a time range within which submarine erosion is reported from the Ross Sea (hiatus above early Pliocene: Fillon, 1972; Houtz and Davey, 1973; Hays, Frakes et al., 1975) and within which major cooling occurs (Hays and Opdyke, 1967) at the Gauss/Matuyama boundary and at a worldwide scale at 1.2-1.3 m.y. reported by Kennett (1970), Ruddiman (1971), Kent et al. (1971), Keany and Kennett (1973), and Briskin and Berggren (1974). As one of the major objectives of this site was to reach basement, the upper part was spot cored at a fairly wide spacing. Core 2 was cut at 123.5 meters, core depth. All diatom-containing samples of Core 2 between Samples $358-2-1,30-31 \mathrm{~cm}$, and $358-2-4,30-31 \mathrm{~cm}$ were included into the Denticula hustedtii Zone of McCollum (1975). These late Miocene sediments have as characteristic floral elements besides the cosmopolitan Denticula hustedtii: Asterolampra acutiloba, Actinocyclus ehrenbergii, and $A$. ingens species characteristic for temperate waters, and Nitzschia interrupta and Synedra miocenica, which are high-latitude elements and make up only less than $5 \%$ of the total diatom assemblage. In the Pliocene sediments (Core 1, Section 6) besides abundant Synedra miocenica, Eucampia balaustium, a typical Antarctic species, occurs as a new element. The percentage of endemic Antarctic species strongly increases during Pleistocene in the Coscinodiscus elliptipora-Actinocyclus ingens Zone of McCollum (1975) as further new Antarctic and subantarctic species occur: Charcotia actinochilus, Coscinodiscus elliptipora, Nitzschia kerguelensis, N. separanda, Coscinodiscus tabularis, C. lentiginosus. Further cosmopolitan species as Thalassiothrix longissima,
Thalassiosira eccentrica, Actinoptychus undulatus, Coscinodiscus asteromphalus and $C$. lineatus are present. Whereas the species characteristic for the equatorial regions of the Pacific (Burckle, 1972; Muhina, 1971; Schrader, 1973a; Koizumi, 1973a) and Atlantic Ocean (Schrader, in preparation) as Pseudoeunotia doliolus, Asteromphalus imbricatus, Coscinodiscus africanus, C. nodulifer, Nitzschia marina, and Rhizosolenia bergonii are missing in the investigated samples from the Argentine Basin (compare also Gombos, in press). This tendency to an increased percentage of cold water species continues into the Coscinodiscus lentiginosus Zone of McCollum (1975), where besides the cosmopolitan species Thalassiosira oestrupii and Hemidiscus cuneiformis, a further new cold element, Schimperiella antarctica, occurs. In the Pleistocene sediments the Antarctic/subantarctic component represents $50-70 \%$ of the total diatom assemblage.

Today Nitzschia kerguelensis is found in the southwestern Atlantic Ocean at about $35^{\circ}$ longitude with a common occurrence only south of $45^{\circ}$ latitude (compare Hendey, 1937; Hasle, 1975). Other Antarctic and subantarctic species as Eucampia balaustium and Nitzschia angulata are found north of the AAC only very rarely. Whereas Coscinodiscus lentiginosus, $C$. tabularis, and Asteromphalus hookeri are still and not uncommonly found in the subtropical waters of the South Atlantic, besides the there common cosmopolitan and tropical species such as Thalassiothrix longissima, Nitzschia marina, Pseudoeunotia doliolus, Coscinodiscus radiatus, $C$. curvatulus, C. africanus, C. nodulifer, and Hemidiscus cuneiformis (compare Castracane, 1886; Comber in Thompson and Murray, 1895; Karsten, 1906; Heiden und Kolbe, 1928; Hart, 1935; Hendey, 1937; and Hustedt, 1958). Thus if a northward shift of the AAC during Pleistocene of $8^{\circ}-10^{\circ}$ of latitude is accepted, as is indicated by Goodell (1966), Williams (1976), and Hays et al. (1976) most of the observed species in the late Neogene of Site $358\left(37^{\circ} 39^{\prime} \mathrm{S}, 35^{\circ} 58^{\prime} \mathrm{W}\right)$ can be interpreted as autochthonous. But the occurrence of Charcotia actinochilus, today restricted to the Antarctic 


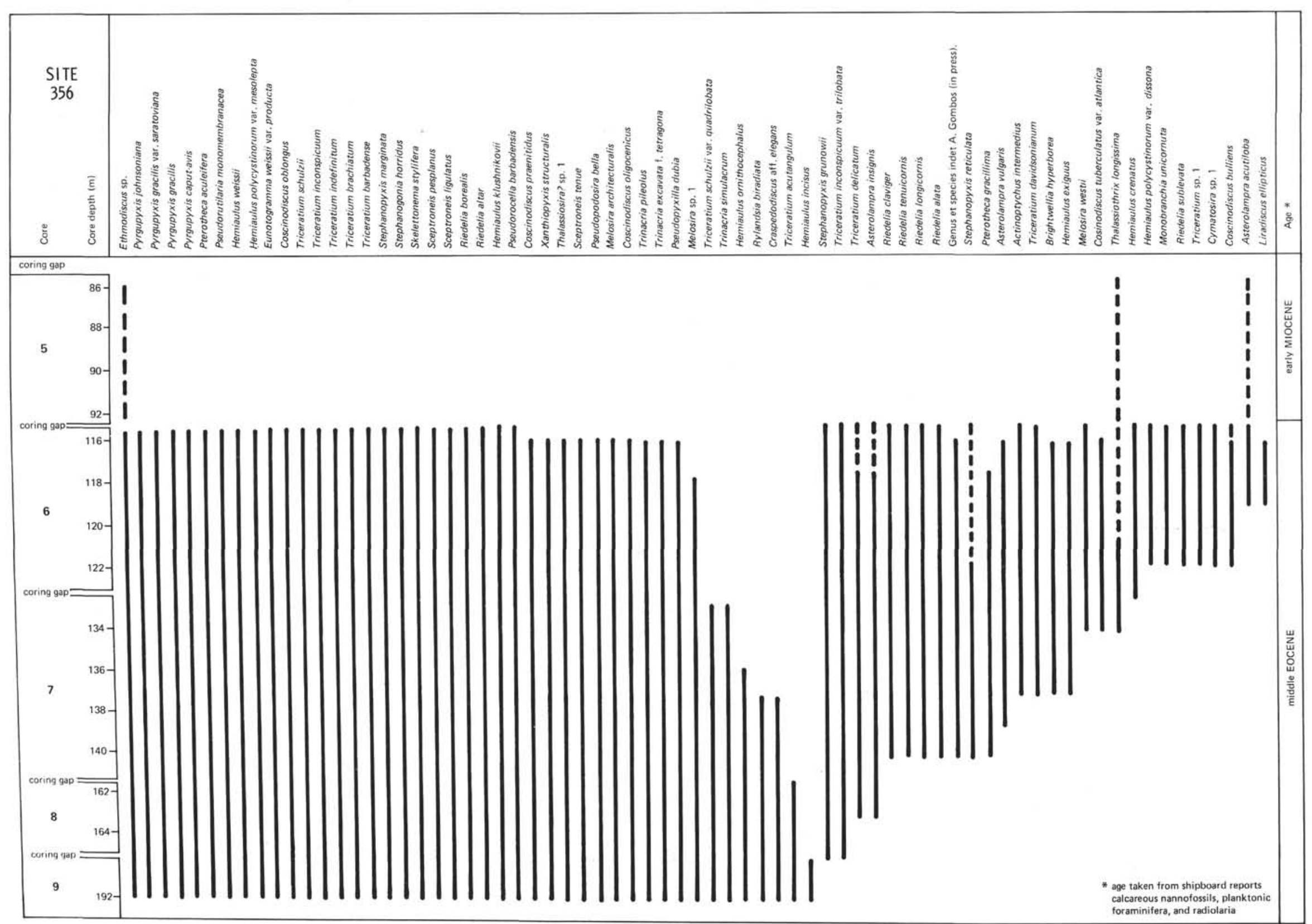


TABLE 4

Middle Eocene Diatoms at Site 356

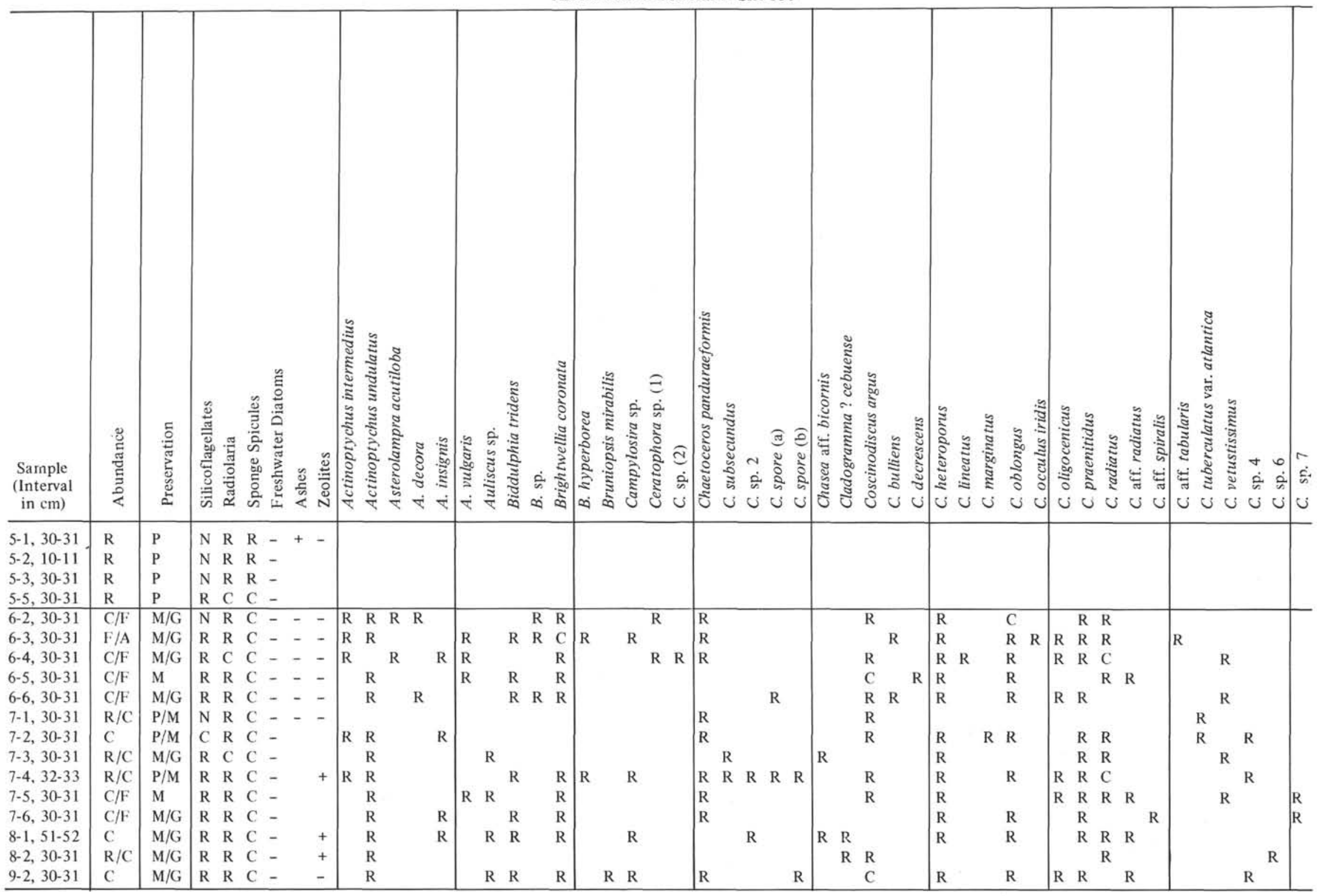




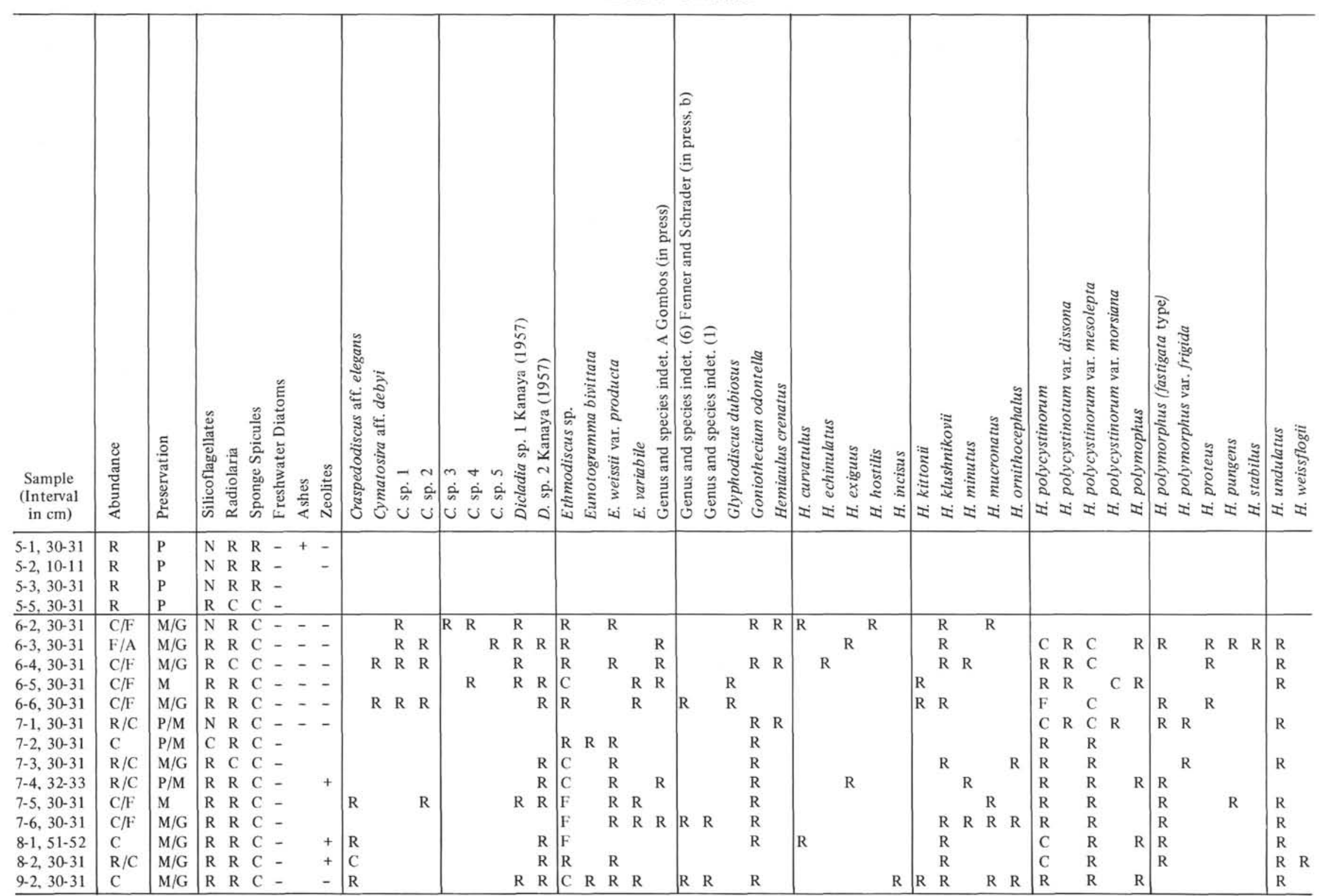


TABLE 4 - Continued

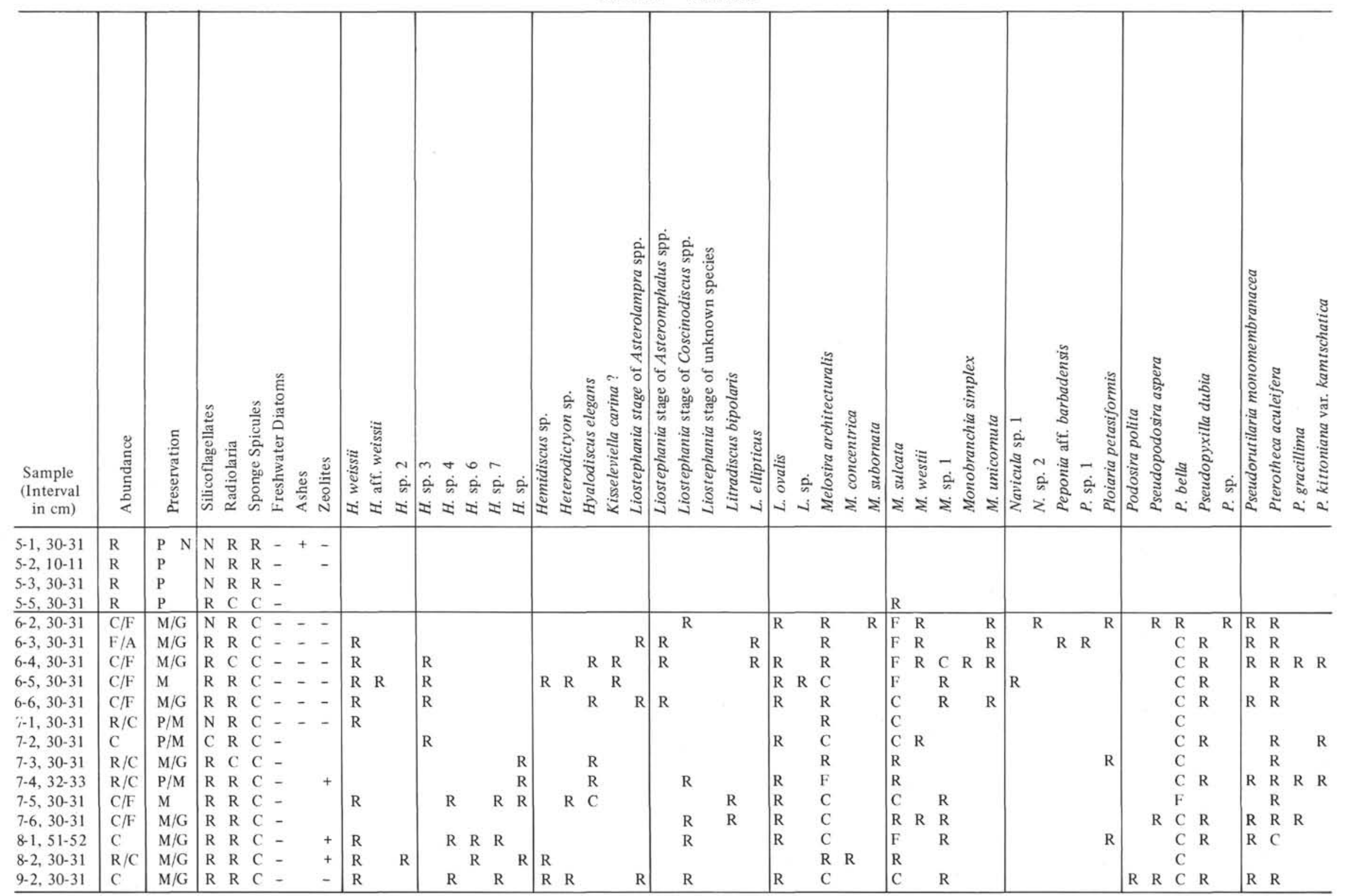


TABLE 4 - Continued

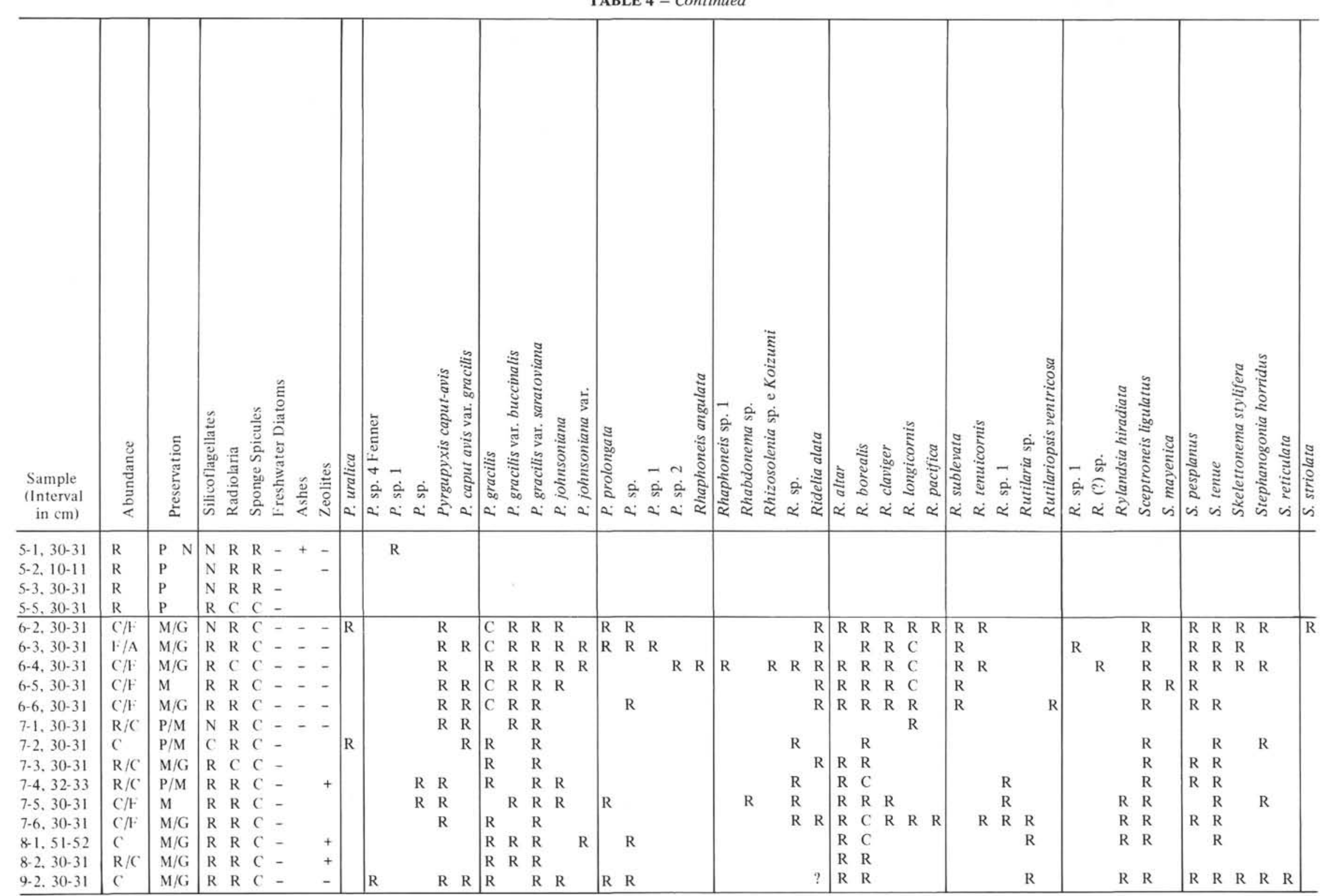


TABLE 4 - Continued

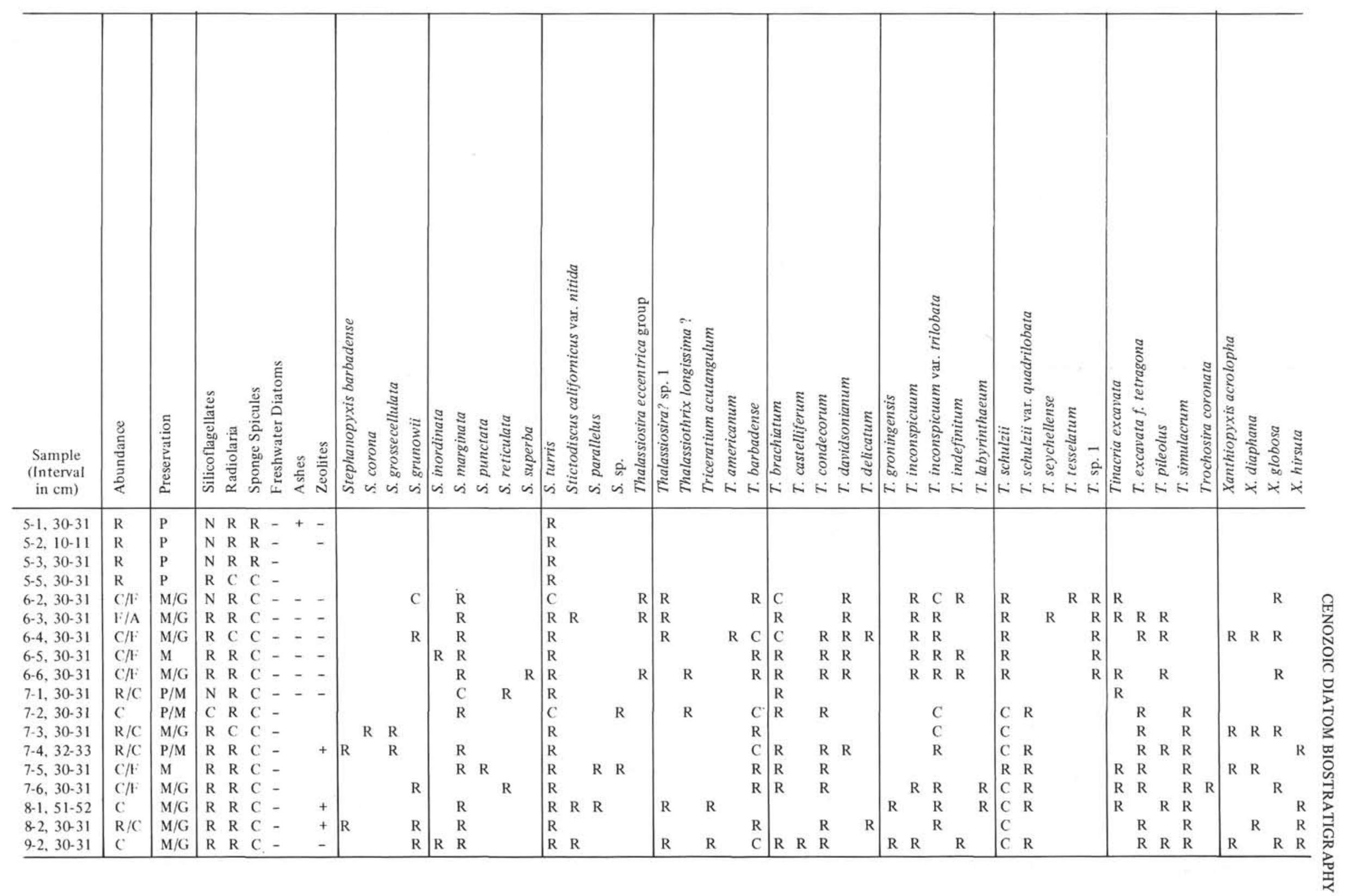


TABLE 4 - Continued

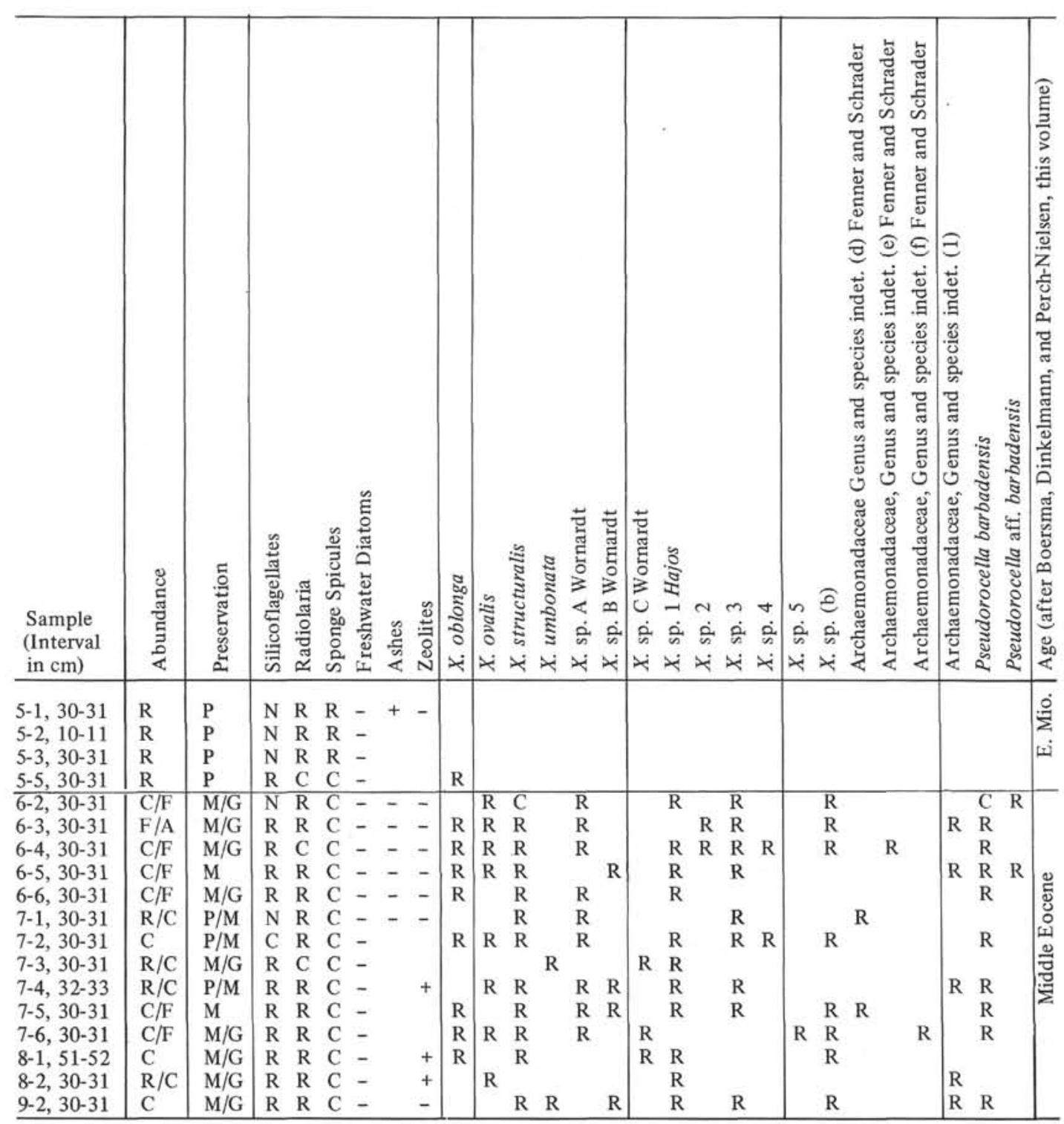


Zone (van Heurck, 1909; Heiden and Kolbe, 1928; Hendey, 1937; Hustedt, 1958; Kozlova, 1964; Manguin, 1960; Hargraves, 1968; Hasle, 1969; Donahue, 1970; and Abbott, 1972), and also the common presence of Eucampia balaustium are astonishing. Their occurrence so far north may partly be explained by a northward transport by icebergs, and partly by a northward transport by the Antarctic Bottom Water (AABW), through the Falkland gap into the Argentine Basin. Such a northward transport of Antarctic diatoms by the AABW has been demonstrated in several papers (Burckle and Biscaye, 1971; Burckle et al., 1973, 1974; Connary and Ewing, 1974; Burckle and Stanton, 1975).

As DSDP Site 358 is positioned in the northeastern Argentine Basin at the southward turning branch of the AABW gyre (Ewing, Le Pichon, and Ewing, 1966) the relatively high quantity of Antarctic species in the PlioPleistocene sediments of DSDP Site 358 could be interpreted as sedimentation out of suspension of the slowing AABW current branch. But the phenomenon in the late Neogene section studied here is, that although a high percentage of the observed diatoms probably is allochthonous, nevertheless and partly just because of these allochthonous diatoms, dating and correlation to the late Neogene diatom stratigraphy established in the Antarctic sector of the Pacific Ocean by McCollum (1975) is possible. This and the fact that older reworked diatoms were found only with extreme scarcity seem to indicate that the AABW was hardly capable of transporting diatoms and not capable of eroding older sediments. Booth and Burckle (in press) also suggest from their findings in the southwestern and central Pacific, that most diatoms are not resuspended by the AABW once they are deposited.

If the hydraulic quartz-equivalent grain diameters are considered this is understandable: for diatom valves with a diameter between $3 \mu$ and $400 \mu$ the sinking rates lie (according to Smayda, 1970) between $0.2 \mathrm{~m} / \mathrm{d}$ and $125 \mathrm{~m} / \mathrm{d}$. This means in seawater of $0^{\circ}-1^{\circ} \mathrm{C}$ a quartzequivalent grain diameter of $1 \mu$ to $27 \mu$ (law of Stokes used). And at these equivalent grain diameters the velocities needed for erosion are of more than $10^{3}$ higher than those at which sedimentation starts (compare Hjulstr $\phi \mathrm{m}, 1936$; Bagnold, 1954; Sundborg, 1956; Unsōld, in preparation). Turbulence and influence of already suspended material was not considered in this calculation. This difference between the minimum velocity, at which erosion occurs and the velocity at which still material is transported in suspension can explain the probably high percentage of allochthonous Antarctic diatoms and the only very scarce occurrence of older reworked diatoms. A further factor that certainly has modified the described assemblages is the solution of diatom frustules. But no calculations are possible to what extent this solution lead to an enrichment of frustules of Antarctic diatoms.

Single freshwater diatoms of the genus Nitzschia were found in Samples 358-1-4, 90-91 cm and 358-2-2, 30-31 cm; single benthic diatoms (Nitzschia aff. panduraeformis and Diploneis sp.) were found in the Samples 538-1-1, 30-31 cm, 358-1-3, 30-31 cm, 358-1-6, $30-31 \mathrm{~cm}$, and $358-2-1,30-31 \mathrm{~cm}$. So this assemblage characterizes full pelagic conditions.

\section{SUMMARY}

The oldest sediments drilled on DSDP Leg 39 containing diatoms were of middle Eocene age, at Site 356 (age is given by calcareous nannofossils and planktonic foraminifers, Perch-Nielsen, Boersma, this volume). The mid Eocene diatom flora is interpreted to represent tropical/subtropical water conditions as cosmopolitan diatoms and warm-water species as Hemiaulus polycystinorum var. mesolepta and Triceratium schulzii dominate. Further, this middle Eocene diatom assemblage of Site 356 characterizes typical offshore conditions, as only an extremely low percentage $(0.5 \%)$ of diatoms which might be interpreted as benthic was found.

Site 354 did contain an early Oligocene section of diatomaceous chalk, which belongs into the Cestodiscus pulchellus Zone of Jousé (1973). Only single benthic diatoms were found in this tropical assemblage, indicating pelagic conditions. The high diatom content and the contemporary occurrence of pyrite and fish teeth at Site 354 , Core 12 (Boersma, this volume) represent an increase in productivity combined with a probably reduced deposition of carbonate biogenic material due to dissolution.

At Site 358 in the northeastern Argentine Basin sediments from late Miocene-Pleistocene did contain diatoms. A hiatus at the Plio-Pleistocene boundary was observed. The gradual cooling from late Miocene to Pleistocene could be traced by the number of endemic Antarctic/subantarctic species and their relative abundance. The increase of Antarctic species is probably predominantly due to the intensification of the generation of Antarctic Bottom Water which transports Antarctic floral elements northward, but is hardly or not capable of eroding. So, in spite of the high percentage of probably allochthonous diatoms, dating was still possible.

\section{FLORAL REFERENCES AND TAXONOMIC NOTES}

The genera are arranged alphabetically, as are the species within each genus. Species and varieties are treated according to the classifications in Hustedt $(1930,1959)$ and Hendey $(1937,1964)$. In addition references are given to publications providing a comprehensive description and illustrations, which were used for identifying the species. Synonyms were only mentioned in case they are still used. For a comprehensive list of synonyms see Mills (18161932) and Van Landingham (1967-). As emphasis in this study is lain on the Eocene and Oligocene diatoms, which are still insufficiently known, especially the diatoms $<40 \mu$, which are of stratigraphical value, it was tried to catalogue all species observed and to give data concerning their stratigraphic range. New species have been described and their holotypes and paratypes have been designated. The type material will be maintained at the sample collection of DSDP samples of Dr. H.-J. Schrader, address at present: School of Oceanography, Oregon State University, Corvallis, Oregon. New descriptions and additional observations were also given for species and genera insufficiently treated in the literature. In the species descriptions the terminology proposed in: Anonymous, working party on terminology (1975), Fryxell and Hasle (1973), Hasle (1973), Ross and Sims (1973) and Hendey (1964) was followed. Undetermined species were numbered in order to differentiate them and introduce them into the lists of occurrence. Other undetermined species, which were found in only one specimen, were only illustrated, without having got an index-number. The stratigraphical occurrence of such species can be taken from the sample, in which this species was observed, cited on the explanations to the plates. The author is fully aware that the numerical taxonomy used is against the nomenclature rules, but in 


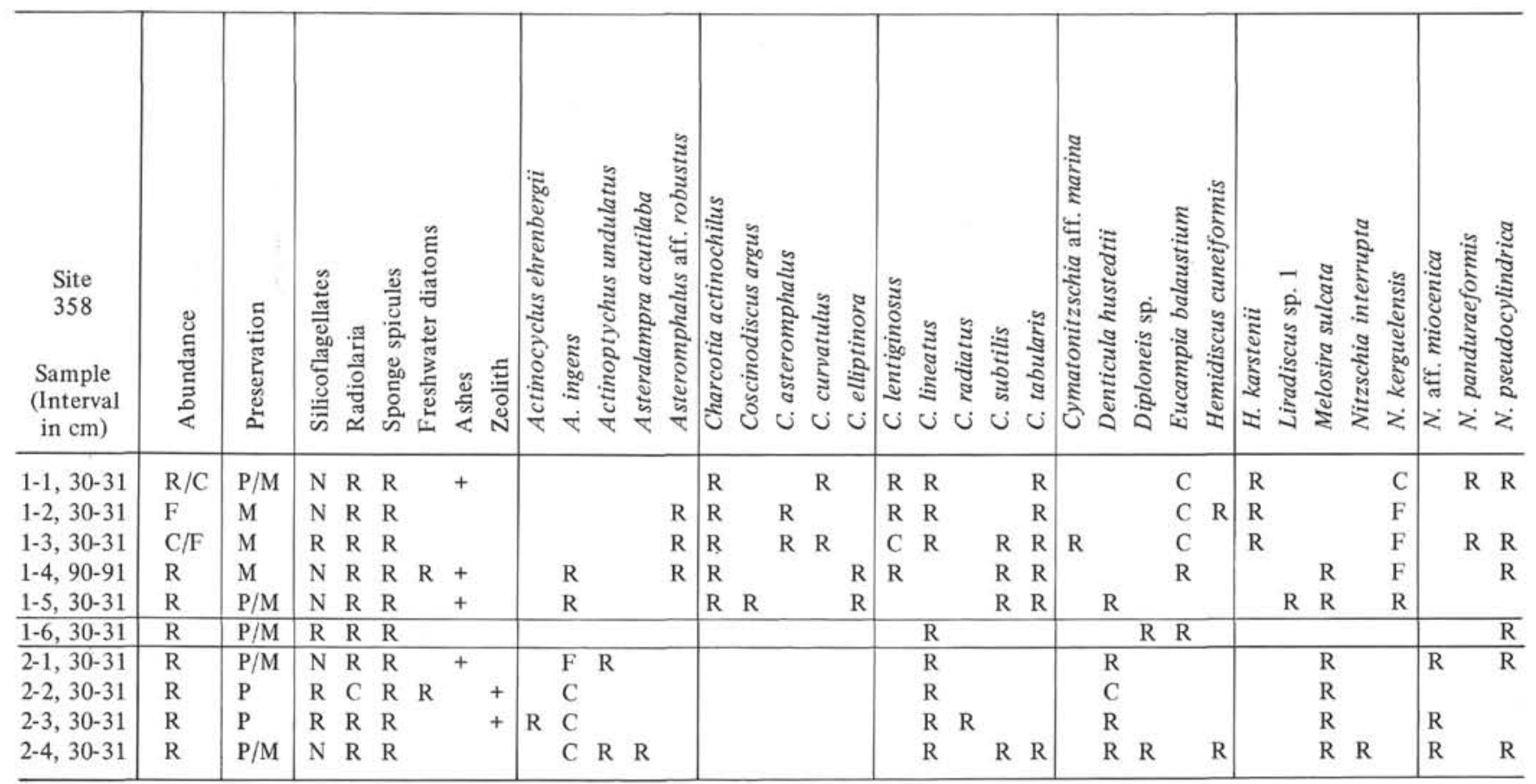

order to include all observed species of importance this system was used. A review of these species must be done, but was not possible within the limited time allotted for this paper. A taxonomic treatment of these species was especially difficult because some of the undetermined species probably belong to the "spore-genera" (as for example: Xanthiopyxis, Dicladia, Chasea, Cladogramma, Stephanogonia, and Liradiscus), which are "form-genera," their ontogenetic connection to diatom genera being unknown in most cases. For those "spore species," which belong to a known species as proven in literature, this species was transferred from the spore-genus to the actual genus, e.g., Xanthiopyxis panduriformis is listed as Chaetoceros panduriformis.

It was tried to give a complete survey on the stratigraphic record to make possible an evaluation of the stratigraphical and also geographical occurrence of the described species. If a comprehensive compilation existed already, this was cited and only additional findings listed.

\section{Genus ACTINOCYCLUS Ehrenberg (1837)}

\section{Actinocyclus ehrenbergii Ralfs in Pritchard (1861)} (No illustration)

Description: Hustedt (1930), p. 525-528, fig. 298.

Age: Not diagnostic.

\section{Actinocyclus ehrenbergii Ralfs var. sparsa (Greg.) Hustedt (1930) (No illustration)}

Description: Hustedt (1930), p. 528-529, fig. 300.

\section{Actinocyclus ingens Rattray (1890)}

(Plate 15, Figure 4)

Description: Kanaya (1959), p. 97-99, pl. 8, fig. 1-4; Kanaya (1971), p. 554, pl. 40, fig. 1-8; Koizumi (1968), p. 207-208, pl. 32, fig. 5-6; Schrader (1973), p. 701, pl. 18, fig. 1-4, 7; Cavallero (1974), App. p. 1, pl. 1, fig. 2; Donahue (1970a), p. 200, pl. 9, fig. a-i.

Remarks: Varies from only slightly undulated valves to those deeply depressed in the center.

Stratigraphic Record: Miocene (Kanaya 1959, 1971; Koizumi, 1968, early to middle Miocene; Schrader, 1973, middle Miocene to lower Pliocene) of the North Pacific and Japan; Miocene of California (Kanaya, 1959). Donahue (1970a) reported this species from the Pleistocene of the South Pacific but it is probably reworked.
Actinocyclus sp.

(Plate 10, Figure 1)

Remarks: This species was found in Sample 358-1-2, 30-31 cm. It shows some resemblance to Actinocyclus miocenicus Jousé (1973), p. 353 , pl. 4 , fig. 25,26 , whose occurrence she described from middle to late Miocene sediments of the tropical Pacific Ocean.

\section{Genus ACTINOPTYCHUS Ehrenberg (1841)}

Actinoptychus intermedius Schmidt (1886)

(Plate 16, Figures 1, 2)

Description: Schmidt et al. (1886), pl. 109, fig. 12; pl. 91, fig. 3.

Remarks: Although Mann (1907) and Kanaya (1957) believe this species to be synonymous with Actinoptychus punctulatus Pantocsek I still separate both as all specimens observed did not show the characteristic hyaline line running from the marginal process toward the center. The species Actinoptychus intermedius from Szent Peter, Hungary (Miocene) and Szakal (leg. Truan) illustrated by Schmidt does not show such hyaline lines. In this study it was found in the middle Eocene sediments of Site 356.

Age: Middle Eocene-Miocene.

\section{Actinoptychus splendens (Shadb.) Ralfs in Pritchard (1861) (Plate 15, Figure 1)}

Description: Hustedt (1930), p. 478, 479, fig. 265.

Remarks: As only a few specimens of this species were found, I followed Schrader (1973) in including all Actinoptychus spp., which possess more than 6 alternatively raised and depressed sectors, as Actinoptychus splendens. This group needs revision, but this was not possible within this study because of lack of material and time.

Age: Not diagnostic.

\section{Actinoptychus undulatus (Bailey) Ralfs in Pritchard (1861)}

$$
\text { (Plate 6, Figure 9) }
$$

Description: Hustedt (1930), p. 475-478, fig. 264.

Remarks: It was not attempted to divide all the "undulatus-like" species of Actinoptychus. All six-rayed specimens of the genus Actinoptychus were listed under this name, unless they are easily distinguishable by e.g. hyaline rays, or as e.g. in Actinoptychus intermedius by a hyaline marginal ring of the elevated segments, which broadens at the corners between neighboring segments.

Age: Not diagnostic. 
TABLE 5 - Continued

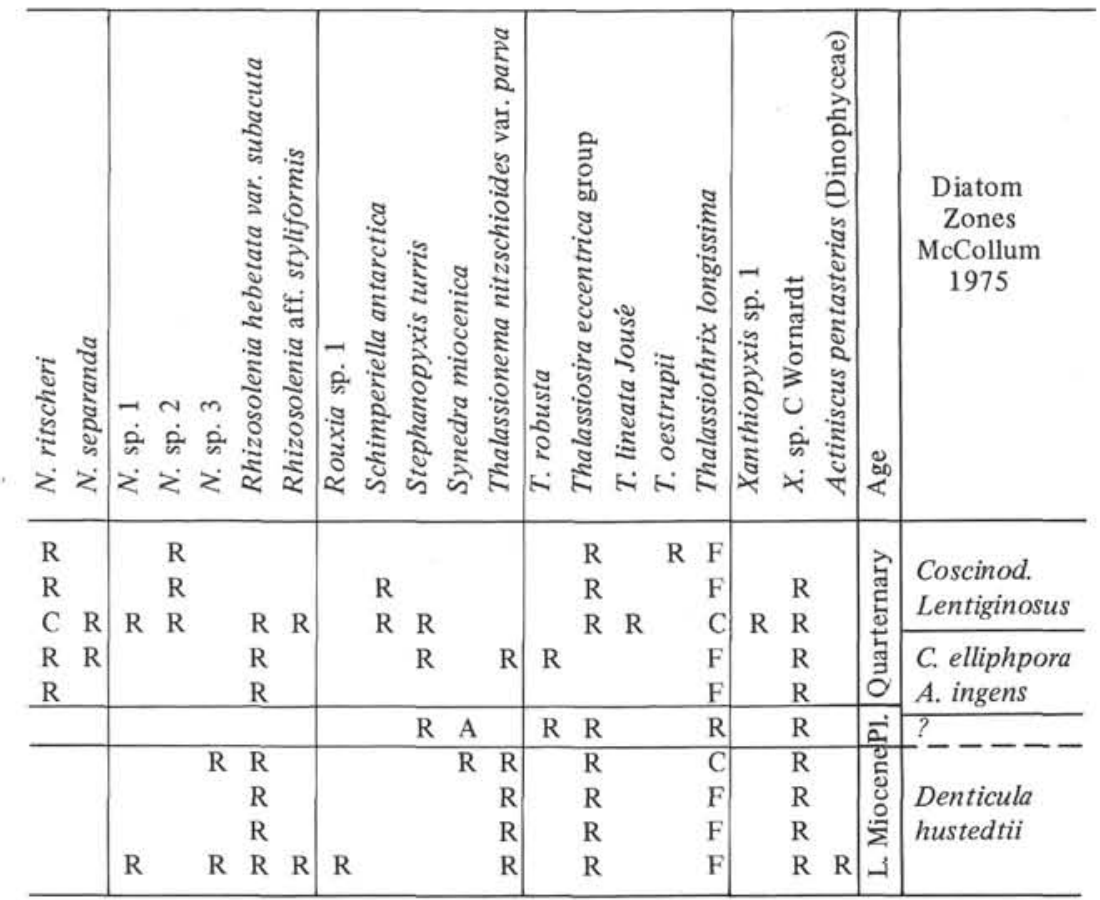

Genus ARACHNOIDISCUS Deane ex Pritchard (1852)

Arachnoidiscus decorus Brown (1933) (No illustration)

Synonym: Arachnoidiscus grevilleanus in Schmidt et al., 1874, pl. 73/3. Arachnoidiscus evanescens in Wornardt (1967), p. 40, fig. 61 .

Description: Brown (1933), p. 71, pl. 6, fig. 3.

Remarks: This species was found in the middle Eocene sediments of Site 356. The genus is known to inhabit the littoral region (Hustedt, 1930).

Stratigraphic Record: Miocene of California (Monterey), as reported by Schmidt et al. (1874-) and Wornardt (1967). Middle Eocene in this paper.

\section{Genus ASTEROLAMPRA Ehrenberg (1844)}

Asterolampra acutiloba Forti in Tempère and Peragallo (1912) (Plate 16, Figure 6)

Description: Schmidt et al. (1874-), pl. 137, fig. 19 (unnamed); Forti in Tempère and Peragallo (1912), p. 337, fig. 696-698; Forti (1913), p. 1564 (30), pl. 3, fig. 1, 5, 6, 9.

Stratigraphic Record: Middle Eocene, this paper (contamination?). Miocene of Licata, Grotte (Italy) and Moron (Spain) (Schmidt et al., 1874; Forti, 1912, 1913; Hendey, 1970), late Miocene (this paper), Pliocene (Burckle, 1973).

\section{Asterolampra decora Greville (1862) (No illustration)}

Synonym: Asterolampra sp. nov. in Schmidt et al., pl. 137, fig. 6 . Description: Greville (1862), p. 45, pl. 7, fig. 4-6; Jousé (1973), pl. 2, fig. 11.

Stratigraphic Record: Middle Eocene (this paper), late Eocene (Oamaru) in Schmidt et al. (1874-), and Oligocene of the tropical Pacific Ocean (Jousé, 1973).

\section{Asterolampra aff. grevillei (Wallich) Greville (1860)} (Plate 18, Figure 3)

Description: Hustedt (1930), p. 489, fig. 274.

Remarks: The observed specimens differ from the species by their larger areolae.
Stratigraphic Record: Early Oligocene of Site 354 (this paper); middle Oligocene of the tropical Pacific (Jousé, 1973); and MiocenePliocene of the tropical Indian Ocean (Schrader, 1974).

\section{Asterolampra insignis Schmidt (1889)}

$$
\text { (No illustration) }
$$

Description: Schmidt et al. (1889), pl. 137, fig. 1-3.

Stratigraphic Record: Eocene-Oligocene. Middle Eocene (this paper), late Eocene of Oamaru (Schmidt et al., 1886), late Eocene-late Oligocene of the Norwegian Sea (Schrader and Fenner, in press), and late Eocene-late Oligocene (Gombos, in press). Late Eocene of west Kazakstan, middle Oligocene of the tropical Pacific Ocean (Jousé, 1973). Late Eocene of the equatorial Atlantic Ocean, DSDP Site 13, Core 3 (Gleser and Jousé, 1974).

\section{Asterolampra marylandica Ehrenberg (1844)} (No illustration)

Description: Hustedt (1930), p. 485-487, fig. 271.

Stratigraphic Range: Early Oligocene-Recent; early Oligocene (this paper). Early and middle Oligocene of the tropical Pacific Ocean (Jousé, 1973). Miocene of Mexico (Hanna and Grant, 1926). Middle Miocene of Trinidad (Lohman, 1973). Miocene deposit of Nottingham, Maryland (Ehrenberg, 1844). Middle MiocenePleistocene of the northeast Pacific Ocean and the tropical Indian Ocean (Schrader, 1973, 1974).

\section{Asterolampra praemarylandica Jousé (1973) (No illustration)}

Illustration: Jousé (1973), pl. 2, fig. 7.

Remarks: All specimens differing from $A$. marylandica by its slightly elevated, starlike central meeting point of the hyaline, radial ribs were determined as $A$. praemarylandica. This species occurred rarely within a large quantity of $A$. marylandica in the early Oligocene of DSDP Site 354.

Stratigraphic Record: Early and middle Oligocene of the tropical Pacific Ocean (Jousé, 1973); early Oligocene of DSDP Site 354 (this paper).

\section{Asterolampra punctifera (Grove) Hanna (1927a)} (No illustration)

Synonym: Asterolampra affinis var. punctifera Grove in Schmidt et al. (1874-). 
Description: Hanna (1927a), p. 109, pl. 17, fig. 3.

Remarks: The specimen illustrated by Hanna (loc. cit.) from the Miocene of California has 14-15 areolae in $10 \mu$. Hanna (loc. cit.) also includes the specimen illustrated from Oamaru in Schmidt et al. (1874), pl. 202 and named Asterolampra affinis var. punctifera, which is much coarser. In the early Oligocene sediments from Site 354 both types: the fine areolated ones (14-16 areolae in 10 $\mu$ ) and the coarser areolated ones $(9-11$ areolae in $10 \mu)$ were found, and both listed under this name. The specimens observed in the Miocene of the Norwegian Sea (Schrader and Fenner, in press a, b) had all 14-16 areolae in $10 \mu$.

\section{Asterolampra vulgaris Greville (1862) \\ (No illustration)}

Description: Greville (1862), p. 47, pl. 7, fig. 17-20; Schmidt et al. (1874), pl. 137, fig. 10-12; pl. 202, fig. 14-16.

Stratigraphic Record: Middle Eocene (this paper); late Eoceneearly Oligocene? of Barbados (Schmidt et al., 1874-); early Oligocene of the Norwegian Sea (Schrader and Fenner, in press), and early Oligocene of the Southern Ocean (McCollum, 1975), early Oligocene, this paper.

\section{Asterolampra sp. \\ (Plate 16, Figure 5)}

Remarks: This species is very closely related to Asterolampra acutiloba, but differs from it by missing the acute lobes at the inner edge of the areolated segments. Only one segment showed this acute lobe. Aside from this, this species is more coarsely areolate than Asterolampra acutiloba.

Age: Middle Eocene.

\section{Genus ASTEROMPHALUS Ehrenberg (1845)}

Asteromphalus oligocenicus Schrader and Fenner (in press [b]) (No illustration)

Deseription: Schrader and Fenner (in press [b]), pl. 21, fig. 8,13, 14; pl. 28, fig. 1 .

Age: Early Oligocene-late Oligocene (Schrader and Fenner, in press [a], this paper).

\section{Asteromphalus aff. robustus Castracane (1875)}

(Plate 17, Figure 24)

Description: Hustedt (1930), p. 496-498, fig. 278.

Genus AULACODISCUS Ehrenberg (1844)

Aulacodiscus sp. 1

(Plate 15, Figure 5)

Genus AULISCUS Ehrenberg (1843)

Auliscus sp.

(Plate 15, Figure 9)

Remarks: The specimen found shows resemblance to Auliscus pulvinatus Cleve, but differs from this species in not having the elevated rings surrounding the center. It is also closely related to Auliscus trioculatus Long, Fuge, and Smith (1946), from which it differs only by its finer punctation.

Age: Middle Eocene.

Genus BAXTERIA Van Heurck (1893)

Baxteria formosa Brun (1896)

(Plate 32, Figure 9)

Description: Brun (1896), p. 234, pl. 20, fig. 1-2.

\section{Genus BIDDULPHIA Gray (1821)}

Biddulphia tridens Ehrenberg (1840)

(Plate 31, Figures 3-5, 11, 12)

Synonym: Biddulphia tuomeyi (Bailey) Roper (1859), p. 8, pl. 1, fig. 1, 2 .

Description: Hustedt (1930), p. 834-836, fig. 491; SheshukovaPoretzkaya (1967), p. 215-217, pl. 37, fig. 1.
Stratigraphic Record: Late Cretaceous-Recent. (For a comprehensive list see Sheshukova-Poretzkaya [1967]). Further reports of this species were given by Schmidt et al. (1874-) from Campeche Bay (Recent or Holocene, Hendey, 1972), by Schrader and Fenner (in press) from the Miocene of the Norwegian Sea, by Hajós (1968) from Hasznos Bohrung 4, Probe No. 24 (Torton). In this study this species was found in middle Eocene sediments. Wornardt (1967) reports this species from the Miocene and Pliocene of California, and Lohman (1973) from the lower middle Miocene of Trinidad.

Biddulphia weissflogii Janisch in "Table Alphabetique" Van Heurck (1884)

(Plate 32, Figure 1)

Description: Grunow in Van Heurck (1882), pl. 100, fig. 1, 2; Schmidt et al. (1874-), pl. 141, fig. 12-23; Castracane (1886), p. 104 pl. 26, fig. 2 .

Remarks: The illustrated specimens were found in the middle Eocene sediments of Site 356.

\section{Genus BRIGHTWELLIA Ralfs in Pritchard (1861)}

\section{Brightwellia coronata (Brightwell) Ralfs in Pritchard (1861)} (Plate 2, Figure 5; Plate 3, Figure 1)

Synonym: Brightwellia pulchra Grunow in Van Heurck (1883), pl. 128 , fig. 9 .

Description: Ralfs in Pritchard (1861), p. 940; Hanna and Brigger (1964), p. 8, pl. 2, fig. 2.

Remarks: The size of this species, quite common in the Eocene samples of Site 356, was highly variable, ranging from $75 \mu$ to $220 \mu$ in diameter. The central part within the ring of elongated, large, hexagonal to rounded areolae (2-3 in $10 \mu)$ is flat. The characteristic feature is the spiral arrangement of areolae within the "coronal ring." A central area may or may not be present. If a central area is present, one single pore (labiate? process) close to the edge of the irregularly, more or less circular, central area can be observed. The number of areolae inside the "coronal ring" is very constant on each valve and varies between 3-5 in $10 \mu$. Outside the "corona" the valve becomes convex and the size of the areolae decreases gradually towards the margin (5-6 areolae in $10 \mu$ ). These areolae are arranged in narrowly spaced radiating lines. Directly at the hyaline margin is a circle of fine areolae (10 in $10 \mu$ ) and a circle of marginal labiate processes. All areolae are punctate with $13-15$ punctae in $10 \mu$.

Stratigraphic Record: This species was reported from the late Eocene of Barbados (Brightwell, 1860, p. 95; Grunow in Van Heurck, pl. 128; Hanna and Brigger, 1964, p. 8; Ross and Sims, 1973); from the late Eocene of DSDP Site 328B (Gombos, in press).

\section{Brightwellia hyperborea Grunow in Van Heurck (1883)} (Plate 2, Figure 4)

Description: Grunow in Van Heurck (1883), pl. 128, fig. 8; Schmidt et al. (1874-), pl. 138, fig. 22

Remarks: The observed diameter of this species varied between $38 \mu$ and $80 \mu$. The areolae were finely punctate with $16-20$ punctae in $10 \mu$.

Stratigraphic Record: Eocene-Oligocene. This species was also described by Jousé (1955), Gleser et al. (1965), and Gleser and Sheshukova-Poretzkaya (1969) from the late Eocene of the Ukraine, west Siberia, and west Kazakstan; by Gleser and Jousé (1974) from middle Eocene sediments of the equatorial Atlantic. It was also found in the dredgings of fossil sediments at Franz-Josef Land (Grunow in Van Heurck, 1883, pl. 128). In this study it was found in the early Oligocene sediments of Site 354 and the middle Eocene samples of DSDP Site 356.

Genus BRUNIOPSIS (Tempère) Karsten (1928)

\section{Bruniopsis mirabilis (Brun) Karsten (1928)} (No illustration)

Description: Brun in Brun and Tempère (1889), p. 27, pl. 8, fig. 1 (as Brightwellia? mirabilis); Kolbe (1954), p. 24, pl. 4, fig. 44; Kanaya (1971), p. 555.

Remarks: Only fragments of this species were found in the middle Eocene sediments of Site 356. 
Stratigraphic Record: Neogene of the southern Atlantic (Gombos, in press; Schrader, 1976); Miocene of the Norwegian Sea (Schrader and Fenner, in press a); the tropical Indian Ocean (Schrader, 1974); northeast Pacific (Schrader, 1973); and Miocene of the equatorial core 76 of the Swedish Deep-Sea Expedition (Kanaya, 1971)

\section{Genus CAMPYLONEIS Grunow (1862)}

\section{Campyloneis grevillei (Wm. Smith) Grunow (1867)}

(Plate 33, Figure 4)

Description: Brun (1891), p. 174, pl. 24, fig. 11 (as Campyloneis notabilis); Hendey (1964), p. 184, pl. 27, fig. 9-11.

\section{Genus CAMPYLOSIRA Van Heurck (1881)}

Campylosira sp.

(Plate 26, Figures 13-14)

Description: Valve semi-lanceolate in outline. At the acute apices, which are slightly bent toward the shorter side of the valve, is a small, round elevated area. The valve face is covered by fine irregularly distributed areolae $(12-16$ in $10 \mu)$. The areolae surround an irregularly shaped hyaline central area, which has an elevated central circular platform.

Discussion: This species was included into the genus Campylosira because of its asymmetrical shape, the lack of a central process, its type of areolation, and the marginal circle of spines. This species differs from Campylosira cymbelliformis by its form: the ventral margin is always slightly convex; and by its hyaline central area.

Genus CERATOPHORA De Toni (1894)

The genus description in Van Heurck (1896, p. 478) was used.

Ceratophora sp. 1

(Plate 34, Figures 3-5)

Ceratophora sp. 2

(Plate 34, Figure 6)

\section{Genus CHAETOCEROS Ehrenberg (1844)}

Chaetoceros panduraeformis (Pantocsek), Gombos (in press) (Plate 36, Figures 7, 8, 12)

Synonym: Xanthiopyxis panduraeformis Pantocsek (1886), vol. I, p. 43 , pl. 29 , fig. 297 .

Description: Forti (1908), p. 133 (as Xanthiopyxis panduraeformis). Gombos (in press), pl. 24, fig. 1-6.

Remarks: Gombos (in press) has proved this species to belong to the genus Chaetoceros.

Stratigraphic Record: Middle Eocene-Miocene. Late Eocene of the southwestern Pacific (Hajós, 1976), early Oligocene of the Southern Ocean (McCollum, 1975), late Oligocene of the South Atlantic (Gombos, in press), Miocene from Szakal, Hungary (Pantocsek, 1886), and Miocene of Italy (Forti, 1908, 1913). In this study, this species was found in the middle Eocene of Site 356. In the Norwegian Sea (Schrader and Fenner, in press [a]) this species occurred in the middle-late Oligocene sediments.

\section{Chaetoceros subsecundus (Grunow) Hustedt sensu Wornardt (1967)} (No illustration)

Description: Wornardt (1967), p. 69, fig. 136

Remarks: This species was found by Wornardt (1967) in the early Pliocene of California. It was found here in the middle Eocene of Site 356.

Chaetoceros spore (a)

(Plate 34, Figure 26) 356.

Remarks: This species was found in the middle Eocene of Site
Genus COCCONEIS Ehrenberg (1838)

Cocconeis various species

(No illustration)

\section{Genus COSCINODISCUS Ehrenberg (1838)}

\section{Coscinodiscus apiculatus Ehrenberg (1844)} (Plate 7, Figure 3)

Description: Hustedt (1930), p. 449-452, fig. 248. Age: Early Oligocene-Recent.

\section{Coscinodiscus argus Ehrenberg (1838)} (No illustration)

Description: Hustedt (1930), p. 422-424, fig. 226.

Remarks: The early Oligocene specimens observed, in general had smaller areolae (3-4 areolae in $10 \mu)$ between the center and 
margin than the living species. The size of the areolae decreases towards the center to $4-5$ areolae in $10 \mu$ and towards the margin to 7 areolae in $10 \mu$. Therefore these specimens are identical in areolation to Coscinodiscus heteroporus found in the early Oligocene and middle Eocene samples of Site 356 but lack the ringlike elevation of the latter species. Because of the last criterion the Coscinodiscus heteroporus specimens were listed separately in this study. For discussion see $C$. heteroporus.

\section{Coscinodiscus asteromphalus Ehrenberg (1844)} (No illustration)

Description: Hustedt (1930), p. 452-454, fig. 250.

Coscinodiscus bulliens A. Schmidt (1878) (Plate 2, Figures 2, 3)

Description: Schmidt (1878) in Schmidt et al. (1874-), pl. 61, fig. 11, 12; Pantocsek (1886), vol. I, p. 70, pl. 17, fig. 149.

Remarks: The observed specimens were 35 to $50 \mu$ in diameter, with 3 areolae in $10 \mu$ in the central part. Outside the irregular circle of enlarged areolae, the areolae decrease in size up to 10 areolae in $10 \mu$ near the margin.

Stratigraphic Record: Eocene-Miocene. This species was found in the middle Eocene sediments of Site 356 and in the early Oligocene sediments of Site 354 (this study). Schmidt (1878-) reported it from the late Eocene and early Oligocene of Barbados, Hajos (1976) found it in the late Eocene sediments of the southwestern Pacific, and Pantocsek (1886) described the species from the marine locality Sz. Peter (Miocene).

\section{Coscinodiscus curvatulus Grunow in Schmidt et al. (1878)} (Plate 9, Figure 9)

Description: Hustedt (1930), p. 406-410, fig. 214; Grunow (1884), p. $82-83$, pl. 4 , fig. $13,14$.

\section{Coscinodiscus decrescens Grunow in Schmidt et al. (1878)} (Plate 7, Figure 4)

Description: Hustedt (1930), p. 430, fig. 233.

Stratigraphic Record: Jousé (1974): late Eocene of Siberia, EastUral, Kazakstan, tropical Pacific and Atlantic Ocean; middle Eocene-early Oligocene (this paper); Grunow (1884) Franz-Josef Land; Springfield, Barbados (Tempère et Peragallo, 1889-1895). Hendey (1964) reports this species as frequent from the North Sea.

\section{Coscinodiscus demergitus n. sp. \\ (Plate 4, Figures 1-3)}

Description: Valve circular, slightly convex with a depressed central part. A central, hyaline, irregularly shaped area may or may not be present. The observed valve diameter was $29-40 \mu$. The areolae are arranged in close radiating rows. The size of the areolae on each valve respectively is rather constant: $9-10$ in $10 \mu$, with an abrupt change in size at the margin, where $14-16$ areolae fall into $10 \mu$. At the marginal end of the longest rays, running from the center to the margin, a structural element is positioned, which might be a labiate process, but which also might be a pseudonodule. To clear this, electron microscopical studies are necessary.

Discussion: Because of the uncertainty concerning the character of the discussed marginal structure the placement of this species into the genus Coscinodiscus just follows the convention, but has to be regarded as tentative. This species differs from the Eocene Coscinodiscus mossianus Greville (1865, p. 25) by its depressed central part, and the size of the areolae, and its finely punctate margin. The Eocene C. griseus Greville (1861, p. 230) also has a depressed center like $C$. demergitus and a similar arrangement of radial rays. It differs by having a prominent hyaline margin with a row of extremely minute puncta on its inner boundary and a finer areolation. Those specimens from Barbados which Gleser and Jousé (1974) illustrate under the name $C$. griseus Grev, seem to have a more or less central nodule and to have a distinct hyaline submarginal ring, bounded in an irregular line with the outer ends of the rows of areolae, which places this species in my opinion close to C. oligocenicus Jousé, especially since specimens identical to those illustrated by Gleser and Jousé (1974) occurred together with $C$. oligocenicus in the lower Oligocene samples of Site 354 , and are listed in this study as C. oligocenicus.
Holotype: Plate 4, Figure 1 from DSDP Leg 39, Sample 354-12-1, 49-50 cm.

Paratype: Plate 4, Figure 2 from DSDP Leg 39, Sample 354-12-1, 49-50 cm.

Age: Early Oligocene.

Coscinodiscus elegantulus Greville (1861a) (No illustration)

Description: Greville (1861a), p. 42-43, pl. 4, fig. 8 .

Remarks: Greville (1861a) describes this species as a rare form of Barbados (late Eocene-early Oligocene). Single specimens of this species were found in the early Oligocene sediments of Site 354.

Age: Late Eocene(?)-early Oligocene.

\section{Coscinodiscus elliptipora Donahue (1970a) \\ (No illustration)}

Description: Donahue (1970a), p. 201, pl. 4, fig. e, i-m.

Stratigraphic Record: This species was found to be restricted to the early and upper Pleistocene of the Antarctic region, with its uppermost occurrences just above the Brunhes/Matuyama boundary (Donahue, 1970a; Abbott, 1970; McCollum, 1975, this paper). The findings of this species in the late Pleistocene (Nitzschia kerguelensis Zone of Donahue, 1970) by Schrader, 1976, probably are due to reworking.

\section{Coscinodiscus excavatus Greville var. semilunaris Grunow (1884) (Plate 10, Figures 13, 14)}

Synonym: Craspedodiscus coscinodiscus Ehr. var.? Jousé, 1973, pl. 2, fig. 1; not Craspedodiscus coscinodiscus Ehr.

Description: Grunow (1884), p. 73.

Remarks: Areolae radiating from the center toward the margin only slightly increasing in size from 4 areolae in $10 \mu$ to 3 areolae in $10 \mu$.

Stratigraphic Record: Late Eocene(?)-early Oligocene of Newcastle Estate, Barbados (Grunow, 1884); and Oligocene of the tropical Pacific Ocean (Jousé, 1973). In this study it was found in the early Oligocene sediments of Site 354 .

Coscinodiscus excavatus Greville var. tuberosa n. var. (Plate 10, Figures 11-12; Plate 11, Figures 1-3)

Description: Valve circular, slightly convex with 2-4 large subcentric excavations lying opposite each other, one forming a hump, the other a groove. The dimension of the excavations is about $1 / 3-1 / 4$ of the valve diameter. The areolae are arranged in radial rows slightly curved towards an eccentric point of departure, which lies at the edge of a groove-excavation. The size of areolae decreases from the margin towards the center from 3-4 areolae in $10 \mu$ to 6-7 areolae in $10 \mu$. The grooves and humps show a different areolae arrangement: on the hump the areolae are the same size as on most part of the valve, but on the groove they are much finer, and also show radial arrangement. Margin striate (6-10 striae in $10 \mu)$. Valve diameter, 80$130 \mu$.

Discussion: This variation of Coscinodiscus excavatus differs from C. excavatus var. quadriocellata by its two excavations lying opposite to each other, the one being a hump, the other one being a groove, and the eccentric meeting point of the rows of areolae.

Holotype: Plate 11, Figure 2 from DSDP Leg 39, Sample 354-12$5,82-83 \mathrm{~cm}$.

Paratype: Plate 10, Figure 12 from DSDP Leg 39, Sample 354-12$3,2-3 \mathrm{~cm}$

Age: Early Oligocene.

Coscinodiscus excavatus Greville var. quadriocellata Grunow (1884) (Plate 11, Figure 4; Plate 37, Figure 16)

Description: Greville in Ralfs in Pritchard (1861), p. 829, pl. 8, fig. 26; Grunow (1884), p. 73.

Stratigraphic Record: Late Eocene?-Miocene. Late Eocene?-early Oligocene of Barbados (Grunow, 1884, p. 73). Jousé (1973) describes this species from lower and middle Oligocene sediments of the tropical Pacific and Miocene sediments from this area (Jousé, 1974). Greville reported this species from the middle Miocene of Virginia; Reinhold (1937) from the middle Miocene of Java; and Lohman 
(1973) from the middle Miocene of Trinidad. The number of excavations seems to show no clear evolutionary trend. From Miocene sediments, specimens with 4 (Jousé, 1974), 6 (Reinhold, 1937), or even 8 excavations (Lohman, 1973) have been illustrated. Further studies must be made in order to define more clearly evolutionary trends and taxonomy.

\section{Coscinodiscus gorbunovii? Sheshukova-Poretzkaya \\ in Sheshukova-Poretzkaya and Moissejeva (1964)} (Plate 6, Figure 5)

Description: Proshkina-Lavrenko et al. (ed.) (1974), pl. 69, fig. 13.; Jousé (1966), pl. 1, fig. 20,21; Sheshukova-Poretzkaya and Moissejeva (1964), p. 94, pl. 2, fig. 1-5.

Remarks: This species is described by Jousé (1966) from early Pliocene freshwater deposits in West Siberia and the Far East. The specimen illustrated was found in lower Oligocene sediments of Site 354.

\section{Coscinodiscus heteroporus (working name)}

(Plate 7, Figures 1, 2; Plate 8, Figure 1)

Description: Ehrenberg (1844), p. 265; Grunow (1884), p. 74-75; Hustedt (1930), p. 423-424.

Remarks: This species was distinguished by Grunow (1884) from Coscinodiscus argus Ehr. by its smaller areolation and a ringlike elevation halfway between margin and center, on which the areolae are the largest, decreasing in size toward the center and towards the margin. A hyaline central space was not always present in his specimens, which he described from fossil locations near Nottingham and Monterey. He also observed living specimens near Elephant Point in Bengalen. Hustedt (1930) rejected $C$. heteroporus as an independent species and included it into $C$. argus Ehr. because he believed the distinctive markings to be of highly variable character. use the species $C$. heteroporus as a working name because I found that in the middle Eocene and early Oligocene material of Sites 356 and 354 most specimens are of the "heteroporus-type," but none of this type occurs in the late Miocene-Recent. This group requires further investigation. Kanaya (1957), in the Eocene Kellogg and Sidney shales, found all gradations from flat to concave forms, and from forms with no hyaline central area to those with a clearly open central area. For stratigraphic records see Kanaya (1957, p. 85), and Kanaya (1959, p. 73-74). The measurements of the specimens found here were: valve diameter, 55-65 $\mu$; size of areolae on the elevated ring, 3-4 areolae in $10 \mu$, decreasing in size towards the depressed center to 4-5 areolae in $10 \mu$, and towards the margin to $6-7$ areolae in $10 \mu$. An irregularly shaped, hyaline central area was present in all observed specimens.

\section{Coscinodiscus lentiginosus Janisch (1878) in Schmidt et al. (1878)} (Plate 1, Figures 8, 11-13)

Description: Hustedt (1958), p. 116, pl. 4, fig. 22-25; Fenner et al. (1976), pl. 7, fig. 4-6.

Remarks: This very common species of the southern ocean (Hustedt, 1958, p. 116) with a single recent occurrence from the subtropical region (listed in Fenner et al., 1976) was also found fossil in upper Pliocene sediments of the southern ocean by McCollum (1975), Schrader (1976), and Gombos (in press, Leg 36). Also in the samples here examined this species was not found deeper than late Pliocene (Sections 358-1-3 to 358-1-2). The valve is circular, flat to slightly convex. In some specimens the center was depressed. Also the structure of this species is highly variable: from loosely, irregularly scattered areolae to a clear radial arrangement, to an "eccentrica"arrangement, or even to a close-set fasciculate arrangement. Independent of the "large-scale" arrangement of areolae on the valve face, there are always clusters of somewhat more close-set areolae irregularly distributed over the valve face. These clusters consist of one special, central "pore," which is surrounded by six areolae. The character of this central "pore" could not be cleared sufficiently by light-microscopical study. But the "pores" have the appearance of strutted tubuli. If this would be the case, the position of this species in the genus Coscinodiscus would be wrong and would have to be changed into Thalassiosira. To clear the character of these special "pores" electron microscopical studies are necessary. At smaller magnifications and smaller apertures of the objective $(<0.40)$ these clusters of slightly closer set areolae with the special "pore" in their center appear as darker spots (Plate 9, Figure 8). An earlier illustration of a C. lentiginosus showing these clusters was given in A. Schmidt et al. (1874-), pl. 58, fig. 11a, from the Tafelbai. The observed valve diameter varied from $26-45 \mu$. The margin was finely striate: $12-14$ striae in $10 \mu$. The single prominent marginal "apiculus" is the typical character of this species.

Age: Late Pliocene-Recent.

\section{Coscinodiscus lineatus group Ehrenberg (1838} (No illustration)

Description: Hustedt (1930), p. 392-394, fig. 204; Hendey (1937), p. 248 .

\section{Coscinodiscus marginatus Ehrenberg (1841}

(Plate 8, Figures 3, 7)

Description: Hustedt (1930), p. 416-418, fig. 223.

Remarks: This species was found in the Eocene and lower Oligocene sediments of Site 356 and 354. It varies greatly in size; diameters of $33-96 \mu$ were observed. The size of areolae varies depending on the valve size. In the small specimens $4-5$ areolae in $10 \mu$ were found in the central part decreasing in size towards the margin to 6-7 areolae in $10 \mu$. In the large specimens $2-3$ areolae in $10 \mu$ were found in the central part of the valve decreasing to $4-5$ areolae in $10 \mu$ at the margin.

Stratigraphic Record: For Upper Cretaceous-Recent stratigraphic record see Kanaya (1957, p. 88-89), and Kanaya (1959, p. 81). New reports of this species can be found in Schrader (1973); McCollum (1975); Koizumi (1973); Hajós (1976); and Jousé (1973).

\section{Coscinodiscus occulus iridis Ehrenberg (1839) (No illustration)}

Description: Hustedt (1930), vol. I, p. 454-459, fig. 252.

Remarks: This species was found in the middle Eocene and early Oligocene samples of Sites 354 and 356.

\section{Coscinodiscus oblongus Greville (1866} (No illustration)

Description: Greville (1866), p. 4, pl. 1, fig. 9, 10

Age: Eocene-middle Oligocene. Eocene of California (Hanna, 1931; Kanaya, 1957); late Eocene-early Oligocene? of Barbados (Greville, 1866); late Eocene-middle Oligocene of the Norwegian Sea (Schrader and Fenner, in press a); late Eocene of Site 356 (this study); and late Eocene of Oamaru (Grove and Sturt, 1889), late Eocene of the North-Donez Basin (Gleser et al., 1965).

\section{Coscinodiscus oligocenicus Jousé (1973)} (Plate 4, Figures 5-10)

Synonym: Coscinodiscus griseus sensu Gleser and Jousé (1974), p. 56, pl. 1, fig. 10 not Coscinodiscus griseus Greville (1863)

Description: Jousé (1973), p. 348, pl. 1, fig. 6-8, 16.

Remarks:Typical for this species is an isolated, eccentrically standing labiate? process. The arrangement of the rows of areolae is highly variable. A simple radial arrangement, but also a fasciculate arrangement with the following rows within a fascicle being shorter and parallel to the first and longest row of each fascicle, was observed as well as a "curvatulus-like" or even "africanus-like" eccentric arrangement. But all had the characteristic hyaline ring between the margin and the flat part of the valve face. The center can be loosely or closely areolated with an irregular more or less developed hyaline ring around it. The diameter of specimens observed in this study varies from $21-53 \mu$. The size of areolae varies from 4-8 areolae in $10 \mu$. Within one specimen the size of areolae varies only slightly. Extremes of the observed total variation in the size of areolae can be seen in one sample. Jousé distinguishes between the species, which she found common in the middle Oligocene and the upper Oligocene, and Coscinodiscus oligocenicus var. nodosus, which shall differ from this species in having an "eccentric nodule." But as this "eccentric nodule" can also be seen in the illustrations of the species, the only mark of distinction might be the size of areolae. 
In the material examined this species was randomly found in the Eocene samples of Site 356. These Eocene specimens seemed to be characterized by a slightly coarser areolated margin, 10 areolae in $10 \mu$, than 13-15 areolae in $10 \mu$ as in the Oligocene specimens of Site 354.

Stratigraphic Record: Eocene (Gleser and Jousé, 1974; this paper); Oligocene (Jousé, 1973; this paper).

\section{Coscinodiscus perforatus Ehrenberg (1844)} (Plate 9, Figures 1, 6)

Synonym: Coscinodiscus perforatus Ehr. var. cellulosa in Lohman (1973), pl. 2, fig. 4; not Coscinodiscus perforatus Ehr. var. cellulosa Grunow (1884). Coscinodiscus obscurus Ehr. var. minor in Gleser and Jousé (1974), p. 55, fig. 13; not Coscinodiscus obscurus Ehr. var. minor Rattray (1890).

Description: Hustedt (1930), p. 445-446, fig. 245 .

Remarks: This species was found commonly in the early Oligocene samples of Site 354. Flat valves and convex valves both occurred in the same sample. The convex valves had the ring of largest areolae closer towards the center but the central areolae again were smaller. No complete frustule was found, thus it remains still uncertain whether these two types belong together as a hetero-valvar frustule, characteristic of the Paleogene members of this species.

Age: Eocene-Recent.

\section{Coscinodiscus praenitidus Fenner and Schrader (in press)}

(Plate 1, Figures 6, 9, 15; Plate 3, Figure 3)

Description: Schrader and Fenner (in press [b]), pl. 14, fig. 7-9; pl. 27 , fig. 8 ; pl. 35 , fig. 24 ; pl. 36 , fig. 5 ,

Stratigraphic Record: Late Oligocene of Site 338 (Schrader and Fenner, in press, a, b) and middle Eocene of Site 356 (this paper).

\section{Coscinodiscus radiatus Ehrenberg (1839}

(Plate 7, Figure 6)

Description: Hustedt (1930), p. 420-421, fig. 225; Hanna and Grant (1926), p. 142, pl. 15, fig. 12.

\section{Coscinodiscus aff. radiatus Ehr. (1839)}

(Plate 8, Figure 2)

Description: Hustedt (1930), p. 420-421, fig. 225.

Remarks: The observed specimens of this type (Eocene of Site 356 ) seem to be identical with the Coscinodiscus radiatus illustrated by Jousé (1971b), p. 417, fig. 1 from the Pleistocene of the northern Pacific.

\section{Coscinodiscus sellatus Jousé (1973)}

(Plate 10, Figure 10)

Description: Jousé (1973), p. 348-349, pl. 2, fig. 2-4.

Stratigraphic Record: Middle Oligocene-lower Miocene (Jousé, 1973); early Oligocene (this paper).

\section{Coscinodiscus aff. spiralis Hajos (1976)}

(No illustration)

Description: Hajós (1976) p. 826, pl. 7, fig. 1-3.

Remarks: This name is used as a working name under which the large lower Oligocene and middle Eocene species of Coscinodiscus which show spiral curved radiating rays of areolae are listed. A definite identification was not possible as only broken specimens were found. Size of areolae is 12 areolae in $10 \mu$. In the central part clusters of fine pores (about 20 pores in $10 \mu$ ) are separated by thickenings. Very fine pores also occur at the central end of the secondary rows of areolae. The valves are convex.

\section{Coscinodiscus subtilis Ehrenberg (1841)}

(Plate 8, Figures 4-6)

Description: Van Landingham (1967), p. 16, pl. 5, fig. 2, 3 , $7,8,10-12$; pl. 6 , all fig.; pl. 7, all fig.; pl. 8, fig. 2-6; pl. 9, fig. 3-5; pl. 10, fig. 1, 2, 4 .

Remarks: This species was found in marine as well as in brackish and fresh water deposits (Van Landingham, 1967).

Stratigraphic range: Miocene-Recent.

\section{Coscinodiscus superbus Hardmann in Rattray (1889)}

(Plate 13, Figures 1-5; Plate 14, Figures 1-4) fig. 5 .

Synonym: Cestodiscus pulchellus Greville (1866a), p. 123, pl. 11,

Description: Rattray (1889), p. 458. Valve circular with a broad submarginal part descending towards the broad margin $(2-5 \mu)$. The valve diameter is highly variable $(30-85 \mu)$ as is the valve structure. Convex and concave valves were observed in approximately the same quantity in the same samples. Therefore it appears probable that this species has dimorphic valves. The central convex or concave part is separated from the submarginal part of the valve by a hyaline ring, seen only with difficulty in the small specimens. In the submarginal part of the valve just below the hyaline ring a ring of large labiate processes can easily be seen. A pseudonodulus could not be seen. The areolae of the central convex or concave part of the valve are always larger than the submarginal areolae. The areolae of the central part can be loosely scattered or densely packed in which case they are arranged in radial lines, which might show a secondary spiral arrangement of areolae. The number of areolae in the central part is, dependent upon arrangement, 3-6 in $10 \mu$. A central hyaline area is present in most specimens but can also be missing. The hyaline central area is often finely punctate. In the submarginal part of the valve the areolae are arranged in dense radiating rows. The number of areolae is $8-11$ in $10 \mu$. The margin is distinctly striated with $11-19$ striae in $10 \mu$. This species was very common at Site 354 .

\section{Coscinodiscus tabularis Grunow (1884)} (No illustration)

Synonym: Coscinodiscus endoi Kanaya (1959), p. 76-77, pl. 3 , fig. 8-11. Coscinodiscus nodulifer sensu McCollum (1975), p. 527 , pl. 5, fig. 7-8; not Coscinodiscus nodulifer Schmidt (1878),

Description: Hustedt (1958), p. 119-120, fig. 48-56; Fenner et al. (1976), p. 774, pl. 7, fig. 10-13.

Remarks: The revised description of this species in Husted (1958) and Fenner et al. (1976) shows the high variability of this species, which also encompasses Kanaya's Miocene Coscinodiscus endoi. In his description Kanaya differentiates $C$. tabularis from $C$. endoi by describing $C$. endo $i$ as having a distinct nodule in the center, and a fascicular arrangement of areolae. However, these two criteria are also the characteristic features of $C$. tabularis. The central or slightly eccentric pores of Hustedt (1958) or "areola" of Fenner et al. (1976) is identical with the central nodule of Kanaya (1959). Also the size of the areolae is identical in the Miocene " $C$. endot": (7-8 areolae in $10 \mu$ ) (Kanaya, 1959), and in the Recent $C$. tabularis (5-10 areolae in 10 $\mu$ ) (Hustedt, 1958; Fenner et al., 1976). Gombos (in press) found both $C$. tabularis and $C$. endoi in sediments from Recent to late Miocene. He did not define his criteria for distinction. Schrader (1976) distinguished between the coarser areolated types (5-7 areolae in $10 \mu, C$. endoi) and the finer areolated type (7-9 areolae in $10 \mu, C$. tabularis). He found $C$. endoi to occur from Miocene to early Pliocene and $C$. tabularis from lower Pliocene to Pleistocene and Recent. Further investigations must be made to determine whether this is only a local evolutionary trend or of general significance. In this study $C$. endo $i$ is considered to be synonymous to $C$ tabularis. McCollum (1975) found C. tabularis of the "endoi" type which he described as Coscinodiscus nodulifer, to occur in the Denticula nicobarica Diatom Zone (early Miocene of the Southern Ocean)

Age: Early Oligocene? Miocene-Recent.

\section{Coscinodiscus aff. tabularis}

$$
\text { (Plate 4, Figure 4) }
$$

Remarks: Only one specimen was found in the Eocene samples of Site 356 which differs from Coscinodiscus tabularis by its curved radial rows and eccentrically positioned center. The areolae decrease in size from the center toward the margin.

Coscinodiscus tuberculatus Grev. var. atlantica Gleser and Jousé (1974) (No illustration)

Description: Gleser and Jousé (1974), p. 56, pl. 1, fig. 14-18; pl. 2, fig. 1

Stratigraphic Record: Late Eocene (Gleser and Jousé, 1974); middle Eocene (Site 356, this paper); late Oligocene (Schrader and Fenner, in press, a, b). 


\section{Coscinodiscus vetustissimus Pantocsek (1886)}

(Plate 5, Figure 7)

Description: Hustedt (1930), p. 412-414, fig. 220. Valve circular, flat and with a slightly bent margin. Valve diameter $55-65 \mu$. Valve surface densely areolated with the areolae arranged in radial lines forming fascicles in which the radial rays are all parallel to the first and longest ray of the fascicle. These long rays of each fascicle end at the margin with a labiate process. The size of the areolae increases slightly from the center outward up to 7 areolae in $10 \mu$ and from halfway between center and margin it decreases slightly again toward the margin where 10 areolae occur in $10 \mu$. This size distribution of areolae on the valve face distinguishes this species from all other species with a hyaline marginal ring and a slightly eccentrical process, as $C$. tabularis, and $C$. oligocenicus.

The margin is finely areolated $(16-18$ in $10 \mu$ ), with $2-3$ circles of areolae, which stand in quincunx arrangement. The margin is more or less distinctly set off from the flat part of the valve by an irregular hyaline ring. Within the first marginal ring of areolae are some widely spaced areolae between the labiate processes which are larger than the other marginal areolae.

A typical feature of this species is the slightly eccentric process within the irregularly areolated central part.

Age: Middle Eocene (this paper), late Eocene (Gleser and Jousé, 1974)-Recent.

Coscinodiscus sp. 1

(Plate 6, Figures 7, 8)

Description: Valve discoid, flat; diameter $20-50 \mu$. The areolae decrease in size from the center toward the margin from 8-9 areolae in $10 \mu$ to $10-12$ areolae in $10 \mu$. The areolae are arranged in radial lines forming at least marginally recognizable fascicles. These are easily recognizable on the submarginal part, while the central part of the valve is more or less irregularly areolated. Interstitial mashes are present. In the center there is a small process. The margin is distinct and finely striate (18-20 striae in $10 \mu$. There are 2-3 marginal processes in $10 \mu$. This species is common in the lower Oligocene sediments of Site 354

Discussion: This species differs from Coscinodiscus tuberculatus Grev, var. atlantica Jousé by the irregular arrangement of the areolae in the central part of the valve and its interstitial mash, and from Coscinodiscus sp. 5 by its coarser areolae in the central part.

Coscinodiscus sp. 2

(Plate 6, Figures 1, 2)

Remarks: This species is closely related to Coscinodiscus apiculatus Ehr., but differs from it by its convex valves and the densely areolated submarginal part of the valve. Valve diameter is 85 $110 \mu$. Areolae decrease in size from the center (3-4 areolae in $10 \mu$ ) toward the margin (5-6 areolae in $10 \mu)$. Margin width is $2-3 \mu$ and is coarsely striate (10-13 striae in $10 \mu)$. Marginal processes were not observed. Single specimens of this species were found in the early Oligocene sediments of Site 354. Coscinodiscus apiculatus was described from Miocene deposits of Maryland, Virginia, and Sharktooth Hill (Hanna, 1932, p. 179).

\section{Coscinodiscus sp. 3
(Plate 5, Figure 2)}

Description: Valve circular, convex with an irregularly shaped, hyaline, central area. The areolae are arranged in radial lines forming fascicles. The size of the areolae decreases slightly from the center to the margin from 12 areolae in $10 \mu$ to 18 areolae in $10 \mu$. The margin is finely striate: 24 striae in $10 \mu$. This Oligocene species is very similar to an unnamed species from Mors (Denmark) illustrated in Schmidt et al. (1874-, pl. 58, fig. 31).

\section{Coscinodiscus sp. 4 \\ (Plate 5, Figure 6)}

Description: Valve circular, flat, with a diameter of $35-40 \mu$. Valve face densely areolated. The areolae are arranged in straight lines as in Coscinodiscus lineatus $\mathrm{Ehr}$. The size of the areolae increases slightly from the center toward the margin from 8 areolae in $10 \mu$ to 7 areolae in $10 \mu$. The areolae of the marginal part are large (8-9 areolae in $10 \mu)$ with small punctae at the outer rim. This marginal part is distinctly offset from the flat part of the valve by an irregular hyaline ring, which is the criterion that distinguishes this species from all other species with a "lineatuslike" areolation. The margin is finely striate (16 striae in $10 \mu$ ).

Age: Middle Eocene-early Oligocene.

Coscinodiscus sp. 5

(Plate 6, Figure 6)

Description: Valve circular, convex. The areolae are arranged in radial rows forming fascicles, in which the first row of each fascicle is the longest, the following rows being shorter and parallel to the first one. The size of the areolae is the greatest halfway between center and margin (7-8 areolae in $10 \mu)$, decreasing in size toward the margin (1214 areolae in $10 \mu$ ), and also decreasing towards the center where 12 areolae occur in $10 \mu$. The radial and fascicular arrangement of areolae is lost in the central part of the valve inside the circle, in which the areolae are the largest. In this central part they are densely but irregularly distributed. Irregularly scattered over the valve are "interstitial mashes." At the marginal end of the longest row of each fascicle is a labiate? process. The margin is distinct, approximately $2 \mu$ wide and finely striate (24-26 striae in $10 \mu)$. This Oligocene species differs from Coscinodiscus sp. 1, which was also described from Oligocene sediments, by the decreasing size of areolae toward the center.

\section{Coscinodiscus sp. 6}

(Plate 3, Figure 2)

Description: Valve circular, convex. The areolae are of constant size (8-9 in $10 \mu)$, but become smaller closer to the margin. The areolae are arranged in fascicles, in which the rows of areolae are parallel to the middle and longest row of the fascicle. In the center are some irregularly scattered small processes. Such small processes or spines are also found between center and margin forming 2 rings around the center. The margin is finely striated $(17-19$ in $10 \mu)$. Valve diameter is $35-40 \mu$. This species was found in the middle Eocene sediments of Site 356.

\section{Coscinodiscus sp. 7}

(Plate 3, Figures 6, 9)

Description: Valve circular, convex with an irregularly starlike hyaline central area. The areolae are of constant size on the whole valve (8-9 in 10 $\mu$ ) and arranged in radial rows which form more or less distinct fascicles in which the rows of each fascicle are parallel to the first and longest row of the fascicle and become gradually shorter. Margin is distinct and finely striate, 14-16 striae in $10 \mu$. Valve diameter is $25-40 \mu$. This species was observed in the middle Eocene sediments of Site 356 .

\section{Coscinodiscus sp. 8}

(Plate 5, Figures 3, 4)

Description: The valve is circular, convex. The areolae decrease in size from the center toward the margin, varying from 14 areolae in $10 \mu$ to $18-21$ in $10 \mu$. The areolae are arranged in radial rows forming fascicles, the first row of the fascicle being the longest and having a labiate(?) process at its marginal end. The following rows become shorter. The margin is striate: 20 striae in $10 \mu$.

Age: Early Oligocene.

Coscinodiscus sp.

(Plate 7, Figure 5)

\section{Genus COSMIODISCUS Greville (1866a)}

Although this genus is recommended by Van Landingham (1968) to be combined with the genera Coscinodiscus e.p. and Stephanodiscus e.p., and although this genus in fact needs drastic revision, I retain this genus until a revision is completed.

\section{Cosmiodiscus insignis Jousé (1961) (No illustration)}

Description: Jousé (1961), p. 67-68, pl. 2, fig. 8; Koizumi (1973a), p. 832, pl. 4, fig. 7-11; Sheshukova-Poretzkaya (1967), p. $175-176$, pl. 2 , fig. 1 ; pl. 25 , fig. 2 .

Stratigraphic Record: This species was found in the late Pliocene sediments of Site 358. It is also reported from the Antarctic Pliocene (Schrader, 1976); the Pliocene of the Norwegian Sea (Schrader and Fenner, in press, a, b); Pliocene of Iturup Island (Sheshukova- 
Poretzkaya and Gleser (1962), early Pliocene of the west coast of the Schmidt Peninsula, Kamchatka (Jousé, 1961, 1962), and the Marine Neogene of Kamchatka, North and South Sachalin (SheshukovaPoretzkaya, 1967).

\section{Genus CRASPEDODISCUS Ehrenberg 1844}

\section{Craspedodiscus aff. elegans Ehrenberg (1844)}

(Plate 9, Figure 3; Plate 37, Figure 6)

Description: Schmidt et al. (1874-), pl. 66, fig. 1.

Remarks: The observed middle Eocene specimens were $60-90 \mu$ in diameter. The areolae of the outer part of the valve were arranged in distinct, straight radial rows with intermittent secondary rows. Areolae size is 4-5 areolae in $10 \mu$. In the inner part the areolae are also arranged in radial rows in continuation of the long radial rows of the outer part. The areolae decrease in size from 5-6 to 8-9 areolae in $10 \mu$ toward the center. The margin is finely striate having 8-9 striae in $10 \mu$. These specimens are more finely areolate than the specimen illustrated by A. Schmidt and also differ from this by their distinct radial rows. Further material is necessary to elucidate the taxonomy of the observed specimens.

\section{Genus CYMATONITZSCHIA Simonsen (1974)}

\section{Cymatonitzschia aff. marina (Lewis) Simonsen (1974) (Plate 32, Figure 7)}

Description: Simonsen (1974), p. 56, pl. 41, fig. 5-9.

Remarks: Only one specimen of this benthic species was found in the Pleistocene sediments of Site 358 from the northeastern Argentine Basin. It differs from the tropical species illustrated by Simonsen (1974) by the smaller distance of its hyaline transapical zones which separate the irregularly granulated bands in between. The observed distance in the central part was $3.5 \mu$ and near the apical ends $1.5 \mu$. While in the specimens illustrated by Simonsen (1974) and Meister (1935, as Denticula antillarum) the distance was $5-6 \mu$ in the central part and $2-3 \mu$ in the apical part of the valve.

\section{Genus CYMATOSIRA Grunow (1862)}

The genus description in Hustedt $(1959$, p. 126) and Hendey (1964, p. 160) was followed strictly. Frustules linear in girdle view inflated in the middle and at the ends. Cells usually united in small packets valve to valve (Hendey, 1964), by means of a marginal ring of spines and the inflated central part and the apical ends (Hustedt, 1959). Valve is lanceolate and areolated in regular quincunxarrangement or irregularly scattered. No hyaline axial area is present, but in some forms a central area (see Hustedt, 1959) is present.

Van Heurck (1896) distinguished a genus Rutilariopsis from the genus Pseudo-Rutilaria (Grove and Sturt, 1886) and the genus Cymatosira. This genus is characterized as well by a marginal ring of spines uniting the frustules and by raised apical ends and a convex central part. It differs from the genus Cymatosira by its strong spines in the median portion of the valve, and from the genus PseudoRutilaria by its unique cell (Van Heurck, 1896). SheshukovaPoretzkaya and Gleser (1962, p. 207) introduced a new genus: Kisseleviella, very closely related to the two discussed genera, but distinguished from them by the missing marginal ring of spines and characterized by one to three bulges in the central part equipped with annular tubercules, which link the cells to columns (SheshukovaPoretzkaya, 1967). Another genus closely related to Cymatosira, Rutilariopsis and Kisseleviella is Campylosira Grunow (1882), which is characterized and distinguished from the three other genera by a heteropolarity: its frustule having one convex and one concave valve, and by its asymmetry in respect to the apical axis. Further, this species is characterized by having neither a central area nor a central axis. It is a question of personal valuation whether these additional strong spines in the median position are a criterion sufficient enough to create a new genus.

I have observed in the DSDP Leg 39 material as well as in the DSDP Leg 38 material from the Norwegian Sea (Schrader and Fenner, in press, b) specimens of the same valve shape and the same type of areolation. Some have a marginal circle of spines, others a submarginal circle, or a central circle, or a central plus a marginal circle. Electron microscope studies are necessary to observe the nature of the strong central spines and the apical elevations and define the taxonomic relation among these four genera. Until such studies are done, I will use, with reservation, the given genus descriptions and the names given to species already described. Specimens which represent only different species are now attributed to different genera.

\section{Cymatosira? compacta Schrader and Fenner (in press [b])} (No illustration)

Description: Schrader and Fenner (in press [b]), p. 137, pl. 8, fig. 22,$25 ;$ pl. 25 , fig. 30-32.

Stratigraphic Record: Middle-late Oligocene of the Norwegian Sea (Schrader and Fenner, in press, a, b); middle Eocene of Site 356 (this paper).

\section{Cymatosira aff. debyi Tempère and Brun in Brun and Tempère (1889)} (Plate 32, Figure 11)

Description: Tempère and Brun in Brun and Tempère (1889), p. 36, pl. 7, fig. 18; Sheshukova-Poretzkaya (1967), p. 238, pl. 60, fig. 7 .

Remarks: The species $C$. debyi was found in the Neogene of Japan, Sendai (Tempère and Brun, 1889); Neogene of the Far East, Kamchatka, Sachalin (Sheshukova-Poretzkaya, 1967). Koizumi (1973a) reports this species from the late Miocene of the Northern Pacific. Further studies have to show the relation between the species found in the middle Eocene of Site 356 and those reported from the Neogene.

\section{Cymatosira sp. 1}

(Plate 32, Figures 2-5)

Description: Valve narrow and elongate with a ventricose, inflated, central part. Since only broken specimens were found, no data concerning the valve length can be given. The width at the middle is $7-9 \mu$ and at the narrow elongated parts of the valve, $2.5-3 \mu$. The central, ventricose part of the valve is covered with irregularly distributed areolae varying in size from 10-12 areolae in $10 \mu$. At the narrow, elongated parts of the valve only one row of coarse spines or processes is present. There are 5 such "spines" in $10 \mu$. This row of spines bifurcates, when reaching the ventricose, central part forming a ring of marginal spines around the inflated central part.

This species was quite characteristic for the middle Eocene and early Oligocene sediments studied. The middle Eocene specimens were more coarsely areolated while the early Oligocene specimens were more finely areolated. No similar species was found in the literature.

Cymatosira sp. 2

(Plate 32, Figure 10)

Description: Valve lanceolate with thin, elongated ends, which terminated in a small elevation. Valve length, $45 \mu$; width at the middle, $6 \mu$; and $0.5-0.75 \mu$ at the narrower portions. The central part is surrounded by small, marginal spines which continue as one row of spines into the narrow part of the valve. The valve face is finely areolated. The areolae are widely spaced, leaving free a hyaline, circular, elevated or depressed central area. This species was observed in the middle Eocene of Site 356. It shows some resemblance to Rutilaria areolata Sheshuk in Sheshukova-Poretzkaya and Gleser (1964), but has not the marginal ring of short spines in the central part.

Cymatosira sp. 3

(Plate 32, Figure 14)

Description: Valve narrowly lanceolate with broadly rounded apices, which terminate into a small elevated process. The whole valve face has widely spaced areolae and a ring of marginal spines. Valve length, $35-40 \mu$; width in the middle of the valve, $5 \mu$.

Age: Middle Eocene.

\section{Cymatosira sp. 4}

(Plate 32, Figures 13, 17)

Description: Valve lanceolate with a rhombic central part and elongated, attenuating lateral projections terminating in a narrow apical elevation. A marginal ring of spines is present. The valve face is densely and finely areolated with an irregular arrangement. There are 16 areolae in $10 \mu$. This species was observed in the middle Eocene of Site 356 . 
Cymatosira sp. 5

(Plate 32, Figure 18)

Description: Valves rectangular to quadrangular in shape with narrow attenuating apices terminating in a small elevation. Valve finely and irregularly punctate with a ring of large spines at the margin; valve slightly convex; $14-18$ areolae in $10 \mu$. Valve length, 20$23 \mu$, width at the middle, $10-11 \mu$. This species was found in the middle Eocene of Site 356 (this paper). But it was also found in the middle Oligocene of Site 338, Norwegian Sea (Schrader and Fenner, in press, a, b).

\section{Genus DENTICULA Kützing (1844)}

\section{Denticula hustedtii Simonsen and Kanaya (1961)}

$$
\text { (Plate 32, Figure 21) }
$$

Description: Simonsen and Kanaya (1961), p. 501, pl. 1, fig. 1925 ; pl. 2, fig. 36-47; Schrader (1973), p. 418, pl. 1, fig. 12, 13.

Age: Middle Miocene-earliest Pliocene. Late Pliocene or even Pleistocene occurrences (Gombos, in press; this study; Kanaya and Koizumi, 1970) are probably due to reworking.

\section{Genus DICLADIA Ehrenberg (1845)}

\section{Dicladia sp. 1 Kanaya (1957)}

(Plate 34, Figure 22)

Description: Kanaya (1957), p. 119, pl. 8, fig. 18, 19.

Stratigraphic Record: Eocene (Kanaya, 1957), middle Eoceneearly Oligocene (this study).

\section{Dicladia sp. 2 Kanaya (1957)}

(Plate 34, Figures 20, 21)

Description: Kanaya (1957), p. 119, pl. 8, fig. 20, 21.

Stratigraphic Record: Kanaya (1957) describes this species from the Eocene Kellogg and "Sidney" Shales of California. This species was observed in the middle Eocene of Site 356 (this study).

\section{Genus DIPLONEIS Ehrenberg (1814)}

Only extremely rare occurrences of specimens belonging to this genus were observed. No determination was done. One species is illustrated on Plate 33, Figure 3.

\section{Genus ETHMODISCUS Castracane (1886)}

Ethmodiscus sp.
(No illustration)

Remarks: Only fragments of specimens interpreted as Ethmodiscus were found, but these in great quantities in the middle Eocene samples. All fragments of Ethmodiscus have been placed into this species following the convention of Schrader (1976).

Stratigraphic Record: Middle Eocene-Recent. Middle MiocenePleistocene of the northeast Pacific (Schrader, 1973); tropical Indian Ocean (Schrader, 1974); Norwegian Sea (Schrader and Fenner, in press, a, b); late Eocene-Pleistocene of the south Atlantic (Gombos, in press); and up to Recent in the Pacific Ocean (Wiseman and Hendey, 1953).

\section{Genus EUCAMPIA Ehrenberg (1839)}

\section{Eucampia balaustium Castracane (1886)} (Plate 27, Figures 12-15)

Description: Hendey (1937), p. 285-286, pl. 13, fig. 8-10; Hustedt (1958), p. 136-137, pl. 5, fig. 40-43.

Stratigraphic Record: Middle Miocene to Recent in southeast Pacific (Schrader, 1976; Fenner et al., 1976); McCollum (1975). Pleistocene (Donahue, 1970a; Gombos, in press; and this paper).

\section{Genus EUNOTOGRAMMA Weisse (1854)}

\section{Eunotogramma bivittata Grunow and Pantocsek in Pantocsek (1886)} (No illustration)

Description: Pantocsek (1886), vol. I, p. 48, pl. 26, fig. 247 ; Grove and Sturt (1887), p. 77, pl. 6, fig. 24; Sheshukova-Poretzkaya (1964), p. 76, fig. 4.
Stratigraphic Record: Middle Eocene-Miocene. Late Eoceneearly Oligocene of the Ukraine and the Far East, Sachalin and Kamchatka (Gleser and Sheshukova-Poretzkaya, 1962, 1969; Gleser et al., 1965); late Eocene of Oamaru (Grove and Sturt, 1887); Miocene of Szent Peter, Hungary (Pantocsek, 1886). In this study this species was found in the middle Eocene sediments of DSDP Site 356. The specimens reported by Heiden and Kolbe (1928) from the marine plankton of the Subantarctic zone certainly are stirred up specimens from a Tertiary submarine outcrop.

\section{Eunotogramma productum Grunow in Van Heurck (1883)} (Plate 29, Figure 8)

Description: Van Heurck (1883), pl. 126, fig. 5; Schmidt et al. (1874-), pl. 144, fig. 12-14.

Stratigraphic Record: Grunow in Van Heurck (1883) and Schmidt et al. (1874-) reported this species from Simbirsk (Paleocene). In this study it was found in the middle Eocene of Site 356.

\section{Eunotogramma variabile Grunow in Van Heurck (1883)}

(Plate 31, Figures 7, 15, 16; Plate 33, Figure 7)

Description: Grunow in Van Heurck (1883), pl. 126, fig. 10-12; Grunow in Schmidt et al. (1874-), pl. 144, fig. 7-9, 15-18, 22-25; Grunow (1884), p. 59; Proschkina-Lavrenko (1974), vol. I, pl. 33, fig. 1 .

Stratigraphic Record: Grunow in Van Heurck (1883) and in Schmidt et al. (1874-) describes this species from Archangelsk (Age?) and Simbirsk (Paleocene) and the early Eocene of Mors Juttland (Benda, 1972; Grunow, 1884). In this study it was found in the middle Eocene of Site 356.

Eunotogramma weissei Ehrenberg var. producta Grove and Sturt (1887) (Plate 27, Figures 3-5)

Description: Grove and Sturt (1887), p. 8, pl. 2, fig. 6, 7; Schmidt et al. (1874-), pl. 144, fig. 39-41; Pantocsek (1892), vol. III, pl. 22, fig. 323; Grunow (1884), p. 59, pl. 2(B), fig. 21, 22.

Remarks: The specimens with two long pronounced angles dominated. The distance between the two elongated angles varied from $50-110 \mu$. Only one very small specimen was found with a $30 \mu$ space between the two elongated angles. The elongated angles end with a horn; they are separated from the central part by pseudoseptae; and are themselves also segmented by pseudoseptae. The number of segments observed in one elongated angle ranged from 2 to 8 . The valve surface is finely but irregularly punctated with $10-12$ punctae in $10 \mu$. There is a large, labiate(?) process projecting outward near the third, shorter angle, the end of which is also slightly bent upward. The center of the central part is free of punctae and surrounded by a ring of short ribs. At the valve margin an undulating hyaline fringe surrounds the entire valve.

Stratigraphic Record: Grove and Sturt (1887) described this species from the late Eocene of Oamaru (also Schmidt et al., 1874-, pl. 144). Pantocsek (1892) reports this species from Kusnetzk (Paleocene? Reinhold, 1945). In this study it was found in the middle Eocene of Site 356.

\section{Genus and Species indet. (A) Gombos (in press)} (Plate 25, Figures 1, 4, 10)

Remarks: This species was found in the middle Eocene of Site 356. Gombos (in press) reports this species only from intervals which were otherwise barren of diatoms.

Genus and species indet. (6) Fenner in Schrader and Fenner (in press [b])

(Plate 36, Figures 14-16)

Description: Fenner in Schrader and Fenner (in press, b), pl. 45, fig. $5,11,14$.

Remarks: This species or species group was found in the middle Eocene sediments of Site 356 .

Genus and Species indet. 1

(Plate 34, Figures 16-18)

Genus and Species indet. 2

(Plate 4, Figure 11)

Description: Valve circular, flat, segmented. In the only specimen found there are 7 densely areolated segments ending toward the 
center with one large pore. There is also one marginal process in each hyaline ray separating the segments. The large central part is structureless. This middle Eocene specimen is identical with an unnamed specimen from Oamaru illustrated in Schmidt et al. (1874-, pl. 138, fig. 10). It might also be identical with a specimen illustrated in Proschkina-Lavrenko (1974, pl. 35, fig. 4), which was determined as Stictodiscus kossuthii Pant., but which shows marginal "pores" between the areolated segments as it is in the specimen here described Also closely related is Coscinodiscus normannicus Greville (see also, Grove and Sturt, 1887, pl. VI, fig. 21).

Genus and Species indet. 3

(Plate 34, Figure 19)

Genus and Species indet. (Plate 18, Figure 6)

Genus and Species indet. (Plate 25, Figure 7)

Genus and Species indet. (Plate 32, Figure 12)

Genus and Species indet. (Plate 33, Figure 8)

Genus and Species indet. (Plate 36, Figure 13)

Genus and Species indet. (Plate 34, Figure 31)

Genus and Species indet. (Plate 1, Figure 2)

Description: The valve shape is hemidiscus-like, convex and asymmetrically elliptical, with the dorsal margin convex and the ventral margin nearly straight and only curved at the ends. The ends are rounded and not produced. Neither a pseudonodulus nor marginal processes could be recognized. The valve is covered with close-set areolae, arranged into radial rows, which are slightly curved near the ends toward the ventral and dorsal side. The size of the areolae decreases slightly from the center toward the margin, with 1618 areolae in $10 \mu$ near the center to 22 areolae in $10 \mu$ near the margin. Valve length, $22 \mu$; breadth, $12.5 \mu$. This species differs from species of the genus Hemidiscus by the lack of a pseudonodulus and the marginal processes.

\section{Genus and Species indet.}

$$
\text { (Plate 5, Figure 5) }
$$

Description: Valve circular, convex, densely areolated. The areolae decrease in size from the center to the margin: from 8-10 areolae in $10 \mu$ to $12-14$ areolae in $10 \mu$. The areolae are arranged in radial rows. At the marginal end of the primary rows a labiate? process is positioned. Typical are two processes: one close to the center, the other halfway between center and margin. This species differs from Thalassiosira oestrupii (Ostenfeld) Proshkina-Lavrenko by its distinct marginal labiate? processes.

Age: Middle Eocene?-early Oligocene.

\section{Genus GLYPHODESMIS Greville (1862)}

\section{Glyphodesmis marginata Grove and Sturt (1886)} (No illustration)

Description: Grove and Sturt (1886), p. 323, pl. 18, fig. 3.

Stratigraphic Record: Late Eocene of Oamaru (Grove and Sturt, 1886), middle Eocene of Site 356 (this paper).

\section{Genus GLYPHODISCUS Greville (1862)}

\section{Glyphodiscus dubiosus Hanna and Brigger (1964)}

(Plate 15, Figures 2, 3)

Description: Hanna and Brigger (1964), p. 13, pl. 3, fig. 8, 9.

Remarks: This species was found by Hanna and Brigger (1964) in the Barbados deposits, late Eocene-early Oligocene. In this study it occurred rarely in the middle Eocene to early Oligocene sediments of Sites 354 and 356 .

\section{Glyphodiscus sp.}

(Plate 3, Figure 4)

\section{Genus GONIOTHECIUM Ehrenberg (1841)}

Description: Tsumura (1959).

Goniothecium odontella Ehrenberg (1844)

(Plate 26, Figure 7; Plate 27, Figure 1)

Description: Karsten (1928), p. 301, fig. 419A; Jousé (1951b), p. 60 , pl. 5 , fig. $1-7$.

Stratigraphic Record: Late Cretaceous-Miocene. Late Cretaceous of the Southwestern Pacific (Hajós and Stradner, 1975); middle Eocene of Site 356 (this study); late Eocene-early Oligocene of the southwestern Pacific (Hajos, 1976); late Oligocene of the southeastern Pacific (Schrader, 1976); late Eocene of the South Atlantic (Gombos, in press); late Eocene-Oligocene of the Norwegian Sea (Schrader and Fenner, in press a, b).

\section{Goniothecium rogersii Ehrenberg (1841)}

(No illustration)

Description: Hanna (1932), p. 192, pl. 11, fig. 4-6.

Age: Late Miocene of Site 358.

\section{Genus HEMIAULUS Ehrenberg (1844)}

Hemiaulus altus in Hajós and Stradner (1975) (Plate 24, Figure 15)

Description: Hajós in Hajós and Stradner (1975), p. 931, pl. 5, fig. 17-19.

Stratigraphic Record: From the Upper Cretaceous of the southwestern Pacific (Campbell Plateau), Hajós and Stradner (1975); late Paleocene of Site 327 (Falkland Plateau) by Gombos (in press); and middle Eocene of Site 356 (this study).

Remarks: The species described as Hemiaulus sp. 5 in Schrader (1976), pl. 14, fig. 8) can probably be included into this species.

\section{Hemiaulus bipons (Ehrenberg 1844?) Grunow in Van Heurck (1882)} (Plate 21, Figure 1)

Description: Grunow in Van Heurck (1882), pl. 103, fig. 6-9; Van Heurck (1896), p. 456, fig. 182; Grunow (1884), p. 65.

Stratigraphic Record: This species was reported from the fossil deposit of Nottingham by Grunow $(1882,1884)$, which is of middle Miocene age (Hendey, 1972). In this study this species was found in the early Oligocene sediments of Site 354.

\section{Hemiaulus crenatus Greville (1865d)}

(Plate 22, Figures 11-12)

Description: Greville (1865d), p. 101, pl. 8, fig. 12; Grunow (1884), p. 65 .

Remarks: This species differs from Hemiaulus rossicus Pantocsek (1889) illustrated in Strelnikova (1974) and Proschkina-Lavrenko et al. (1974, pl. 11, fig. 6) by its transapical ribs, which do not reach the mantle of the valve base, while in Hemiaulus rossicus the valve mantle is also segmented by pseudoseptae.

Stratigraphic Record: Barbados (Greville, 1865d; Grunow, 1884) and middle Eocene (this paper).

\section{Hemiaulus curvatulus Strelnikova (1971) (No illustration)}

Description: Strelnikova (1974), p. 96-97, pl. 47, fig. 14-16.

Stratigraphic Record: Late Cretaceous of Western Siberia (Strelnikova, 1974); late Eocene of the Norwegian Sea (Schrader and Fenner, in press, a, b), and middle Eocene of Site 356 (this study).

\section{Hemiaulus echinulatus Jousé (1949)} (Plate 20, Figure 4)

Description: Strelnikova (1974), p. 100, pl. 46, fig. 15-23; Jousé (1951b), p. 53, pl. 3, fig. 3a-c. 
Remarks: Only small specimens of this species were found in the middle Eocene sediments of Site 356.

Stratigraphic Record: Late Cretaceous of the western Ural (Jousé, 1951) and Siberia (Strelnikova, 1974); middle Eocene-early Oligocene (this paper).

\section{Hemiaulus exiguus Greville (1865b) (Plate 20, Figure 5)}

Description: Greville (1865), p. 29, pl. 4, fig. 20.

Stratigraphic Record: Cambridge Estate of Barbados, late Eocene-early Oligocene?(Greville, 1865b), and middle Eocene of Site 356 (this study).

\section{Hemiaulus aff. hostilis Heiberg (1863)}

(Plate 21, Figures 16-17)

Description: Heiberg (1863), p. 48, pl. 1, fig. 11; Strelnikova (1974), p. 99, pl. 47, fig. 10-13.

Remarks: This small species was found in single specimens in the middle Eocene of Site 356. It was also found in the Eocene of the Norwegian Sea (Schrader and Fenner, in press, a, b).

\section{Hemiaulus incisus (Hajós, 1976)}

(Plate 25, Figures 6, 8)

Synonym: Hemiaulus kittonii Schmidt et al. (1874-), pl. 142, fig. 11; not Hemiaulus kittonii Grunow (1883).

Description: Hajós (1976), p. 829, pl. 23, fig. 4-9.

Remarks: A very typical characteristic of this species is the lateral, small spine at the outer side of the long horns. This lateral spine is situated $1 / 4$ to $1 / 5$ way from the apical end of the horn towards its base, a feature typical for the genus Pyrgupyxis.

Stratigraphic Record: Early Eocene of Mors (Schmidt et al., 1874), early Oligocene of the southwestern Pacific Ocean (Hajós, 1976) and lower part of the middle Eocene of Site 356 (this study). Late Paleocene-late Oligocene of the South Atlantic (Gombos, in press).

\section{Hemiaulus kittonii Grunow in Van Heurck (1883)}

(No illustration)

Description: Van Heurck (1883), pl. 106, fig. 6-9; Grunow (1884), p. 61; Schmidt et al. (1874-), pl. 142, fig. 2-8; Strelnikova (1974), p. 96, pl. 42, fig. 12-24.

Stratigraphic Record: Upper Cretaceous-Oligocene. Upper Cretaceous of western Siberia (Strelnikova, 1974); early Eocene of Mors, Jütland (Grunow, 1884; Schmidt et al., 1874); Grunow in Van Heurck, 1883; Benda, 1972), early Oligocene of Site 354 and middle Eocene of Site 356 (this study).

Hemiaulus klushnikovii Gleser in Sheshukova-Poretzkaya and Gleser (1964)

(Plate 25, Figures 12, 14, 15)

Description: Sheshukova-Poretzkaya and Gleser (1964), p. 87 , pl. 3, fig. 8; Proschkina-Lavrenko (1974), pl. 36, fig. 8.

Remarks: This fragile, thin-walled species has an elliptical valve with two long and slender horns ending at their apex in a long spine at the inner side. These long horns are constant in diameter and ornamented with a straight line of areolae $(5-7$ in $10 \mu)$ alternating with small punctae. This seems to be a very characteristic feature of this species. The valve mantle is sparsely and irregularly punctate. Only at its base, just above the hyaline marginal seam, is there a ring of areolae irregularly alternating with small punctae. The keel, surrounding the central part of the valve on both sides runs from horn to horn. The central part of the valves is depressed, its structure is unknown as no specimen in valve-view was observed. The valve diameter is highly variable $(10-60 \mu)$. The length of the lateral, apical projections varies from 43 to $140 \mu$. Pseudoseptae and a central conical projection are not present. This species is easily missed because of its delicate valves.

Age: Middle Eocene-early Oligocene (this paper).

\section{Hemiaulus minutus Greville (1865)} (No illustration)

Description: Greville (1865d), p. 101, pl. 8, fig. 5 .

Stratigraphic Record: Cambridge Estate of Barbados (Greville, 1865 ) and in this study specimens fitting to the description of Grunow were found from middle Eocene to early Oligocene.
Hemiaulus mucronatus Greville (1865a)

(Plate 22, Figure 6; Plate 24, Figure 13)

Description: Greville (1865a), p. 28, pl. 3, fig. 6; Grunow (1884), p. 61 .

Stratigraphic Record: Barbados (Greville, 1865a; Grunow, 1884); and middle Eocene of Site 356 (this study).

Hemiaulus ornithocephalus Greville var. Schmidt in Schmidt et al. (1889)

Illustration: Schmidt et al. (1874-), pl. 142, fig. 26-29.

Remarks: The specimens observed have a circle of spines around a spine in the center of the central segment. This species was reported from Archangelsk and Simbirsk in Schmidt et al. (1874-). In this study it was found in the middle Eocene of Site 356.

Hemiaulus polycystinorum Ehrenberg (1854)

(Plate 21, Figures 13, 14; Plate 22, Figures 4, 5, 7-10; Plate 23, Figures 1-4)

Description: Grunow (1884), p. 65; Schmidt et al. (1874-), pl. 143, fig. 23-29.

Remarks: In the upper part (Core 6) of the middle Eocene section of Site 356 those types of Hemiaulus polycystinorum, which are illustrated on Plate 21, Figures 13, 14, and Plate 22, Figures 4, 5, were especially common. The central segment of these specimens is quadratic to rectangular in lateral view. The horns also have a relatively rectangular shape only slightly broadening towards their base. This type of $H$. polycystinorum was also illustrated in Schmidt et al. (1874-, pl. 143, fig. 24, 28) from Barbados.

\section{Hemiaulus polycystinorum Ehr. var. dissona n. var.}

(Plate 22, Figures 14-16)

Description: This variation differs from the species by its asymmetrical shape. The valve outline is not exactly lanceolate, but one end is broad while the other is more tapered. This characteristic is combined with an asymmetrical central part, which is placed near the broad end, and a difference in the length and width of the two horns. The horn at the broader side is correspondingly wider and is also longer than the horn at the other end of the valve. The central part has in its center a circle of spines. Observed length of the shorter horn from the base to the apical spine is $30-35 \mu$, and of the longer horn, $50 \mu$. Valve length at the base is $58-63 \mu$.

Holotype: Plate 22, Figure 15, from DSDP Leg 39, Sample 356-62, $30-31 \mathrm{~cm}$.

Paratype: Plate 22, Figure 14, from DSDP Leg 39, Sample 356-6$3,30-31 \mathrm{~cm}$.

Age: Middle Eocene.

Hemiaulus polycystinorum Ehr. var. mesolepta Grunow (1884) (Plate 23, Figures 5-9; Plate 24, Figure 7)

Description: Grunow (1884), p. 65, pl. 2(B), fig. 43.

Remarks: The typical feature of this variation is the depressed central part bounded by two transapical furrows against the neighboring raised areas. Valves are lanceolate in outline with long horns, which have a spine at their inner apical end. A further characteristic also described by Grunow (1884) and Kanaya (1957) is the very coarse $(2-2.5$ areolae in $10 \mu)$ subangular areolae on the valve mantle, which decrease in size towards the apical ends of the horns. This characteristic seems to be highly variable. The typical specimens which are coarsely areolated on their mantle are found to occur with specimens which had a finer areolation (3-5 areolae in $10 \mu)$, as well as transitional types occurring between the two extremes. The finer areolate specimens also have a characteristic central, depressed transapical section. In valve-view a labiate(?) process surrounded by a ring of smaller areolae is always found in the center of the central, depressed section. This is also very characteristic for this variety. In the length/height ratio a correlation between long specimens with shorter horns to shorter specimens with longer horns was found. The observed valve diameter at the base varied from $15-80 \mu$ and the height of the horns from $25-80 \mu$.

Stratigraphic Record: This variation was described first from Barbados (Grunow, 1884) and also reported as a characteristic element from the Eocene of the Mt. Diablo Area, California (Kanaya, 1957). In this study it was commonly found in the middle Eocene sediments of Site 356, and Jousé (1968) reported this species from the late Eocene of the Tuamoto Islands. 
Hemiaulus polycystinorum Ehr. var. morsiana Grunow (1884) (No illustration)

Description: Grunow (1884), p. 66, pl. 5(E), fig. 53; Benda 1972 , p. 255 , pl. 4 , fig. $34-35$.

Stratigraphic Record: Early Eocene of Mors, Jütland (Benda, 1972; Grunow, 1884) and of Barbados, Cambridge Estate (Grunow, 1884). In this study this species was found in the middle Eocene of Site 356 .

\section{Hemiaulus polymorphus Grunow (1884)}

(Plate 21, Figure 11; Plate 23, Figures 10, 11; Plate 22, Figure 13)

Description: Grunow (1884), p. 66; Schmidt et al. (1874-), pl. 143, fig. 11-13; Kanaya (1957), p. 105-107, pl. 7, fig. 10, 11 ; Hanna (1927a), p. 114, pl. 18, fig. 9, 10.

Remarks: In nearly all samples of the middle Eocene section of Site 356 asymmetrical specimens of this species were found, which were listed separately as Hemiaulus polymorphus fastigata-type (working name). In these specimens the two horns are bent to the same side. The horn at that side to which both horns are bent is considerably shorter than the other one.

For a stratigraphic record see Kanaya (1957). In this study this species was found in the middle Eocene of Site 356 and the early Oligocene of Site 354.

\section{Hemiaulus polymorphus Grunow var. frigida Grunow (1884) (No illustration)}

Description: Grunow (1884), p. 66, pl. II(B), fig. 47-49.

\section{Hemiaulus proteus Heiberg (1863)} (Plate 21, Figures 3, 4, 2?)

Description: Heiberg (1863), p. 47, pl. 1, fig. 1-11; Grunow (1884), p. 64; Schmidt et al. (1874-), pl. 143, fig. 31.

Valve lanceolate in outline with two relatively short horns, which gradually narrow from the base to the top, at which a spine is splayed to the inner part of the valve. The valve is segmented by pseudoseptae, separating concave segments, which rise to the same level. The segments are densely areolated with an irregular arrangement on the valve mantle. The size of the areolae at the valve mantle is 6-8 areolae in $10 \mu$. The size of the areolae decreases from the mantle toward the center 8-9 areolae in $10 \mu$, where they are arranged in circles around one or two central spines. On the horns, the areolae decrease more considerably in size from the base toward their apical ends, where 14-16 areolae occur in $10 \mu$. Typical for this species, besides the characteristic segmentation, is a row of relatively large areolae parallel to the valve base (4-7 areolae in $10 \mu)$. Observed valve length is $20-53 \mu$, valve height from the base to the end of the spines is $21-31 \mu$.

Stratigraphic Record: Late Eocene-early Oligocene? of Barbados (Schmidt et al., 1874-); early Eocene of Mors, Jütland (Grunow, 1884; Benda, 1972), and middle Eocene of Site 356 (this study).

\section{Hemiaulus pungens Grunow (1884)}

\section{(No illustration)}

Description: Grunow (1884), p. 63, pl. 5, fig. 56; Cleve-Euler (1951), p. 125 , fig. 274.

Remarks: This species was found in the late Oligocene sediments of the Norwegian Sea (Schrader and Fenner, in press, a); the early Eocene of Mors, Jutland (Grunow, 1884; Benda, 1972). In this study it was found in the middle Eocene of Site 356.

\section{Hemiaulus stabilus n. sp.}

(Plate 26, Figure 17)

Description: This very robust species has broad horns, which are slightly straddled toward the apex, and which are ventricosely broadened in their lower part (1/3 of their length). At the apical end the horns bear a long robust spine, at the top of which the hyaline outer keel ends. The central conical projection reaches the same height as the basal thickening of the large horns and has small spines on its top. The mantle is densely but irregularly areolated. There are 8-10 areolae in $10 \mu$. Clusters of areolae are separated by irregularly running ribs.

Discussion: No similar species was found in the literature.
Holotype: Plate 26, Figure 17 from DSDP Leg 39, Sample 356-62, 30-31 cm.

Age: Middle Eocene.

\section{Hemiaulus subacutus Grunow (1884)}

(Plate 24, Figures 8, 14)

Description: Grunow (1884), p. 61, pl. 5(E), fig. 55.

Remarks: The valve has no transapical incisions. The long horns are only slightly broadening at their base and terminate in a broad spine. The middle part of the valve face is slightly elevated. The valve is densely but irregularly punctated, $6-8$ punctae in $10 \mu$, becoming more regularly arranged, in straight lines, at the horns. A narrow hyaline keel at the inner and outer side of the horns is present. This keel is broadening considerably while running along the marginal part of the valve between the horns. Observed valve diameter: $16-42 \mu$, valve height from the base to the terminal spine of the horn: $43-75 \mu$.

Although Grunow (1884) does not illustrate nor describe the small central elevation, which was observed in all specimens found in the early Oligocene sediments of DSDP Site 354, Core 12, the found specimens were included into this species because all other criteria fit.

\section{Hemiaulus undulatus Jousé (1951a)}

(No illustration)

Description: Jousé (1951a), p. 38, pl. 6, fig. 1; Strelnikova (1974), p. 98, pl. 47, fig. 7-9; Proschkina-Lavrenko et al. (1974), pl. 12 , fig. 12 .

Stratigraphic Record: Late Cretaceous of West Siberia (Strelnikova, 1974), and of the Ural (Jousé, 1951). In this study this species was observed in the middle Eocene of Site 356

\section{Hemiaulus weissflogii? Pantocsek (1889)}

(Plate 26, Figure 11)

Description: Pantocsek (1889), pl. 27, fig. 401, 402.

Remarks: This species was reported by Pantocsek (1889) from the fossil deposits of Kusnetzk (age unknown).

Age: Middle Eocene (this study).

\section{Hemiaulus weissii Grunow (1884)}

(Plate 21, Figures 6-8, 9?

Synonym: Hemiaulus subacutus Proschkina-Lavrenko et al. (1974), pl. 36, fig. 10; not Hemiaulus subacutus Grunow (1884).

Description: Grunow (1884), p. 63, pl. 5(E), fig. 52; Schmidt et al. (1874-), pl. 143, fig. 37 (not 38-41)

Remarks: The specimens observed had the typical oval valve outline with horns gradually narrowing from a broad base $5-10 \mu$ wide, towards a narrow apical end $1-3 \mu$ wide, which bears a spine bent towards the inner side. The areolae are arranged in typical radial arrangement on the valve mantle. While the specimen illustrated and described by Grunow had 8 areolae in $10 \mu$, the specimens observed in this study showed a much higher variation in the size of areolae at the central part of the mantle (from 8-4.5 areolae in $10 \mu$ ) with the finer areolated ones occurring in the lower middle Eocene and the coarser areolated ones in the upper middle Eocene. The central "swelling" bears on its center a labiate? process

Stratigraphic Record: Grunow (1884) described this species from Simbirsk (Paleocene? [Reinhold, 1945]). In this study this species was found in the middle Eocene of Site 356. Benda (1972) describes this species from the early Eocene of Mors (Denmark).

\section{Hemiaulus aff. weissii Grunow (1884)}

(Plate 21, Figure 15)

Illustration: Schmidt et al. (1874-), pl. 143, fig. 38

Remarks: This species was included by Witt (Schmidt et al., 1874-, pl. 143) into the species Hemiaulus weissii. But the high mantle and the straight, practically untapered horns and the straight apical spine on each horn differentiate this species distinctly from Hemiaulus weissii. As only rare specimens of this species were found in the middle Eocene sediments of Site 356, not enough material was available for study to define a new species.

Hemiaulus sp. 1

(Plate 23, Figure 12) 
Hemiaulus sp. 2

(Plate 25, Figure 5)

Hemiaulus sp. 3

(Plate 24, Figure 6)

\section{Hemiaulus sp. 4}

(No illustration)

Remarks: This species found in the lower middle Eocene is closely related to Hemiaulus pungens, but differs from the latter in not having the prominent long spines at the end of the horns.

Hemiaulus sp. 5

(Plate 37, Figure 15)

Hemiaulus sp. 6

(Plate 24, Figure 12)

Description: Valve oval in outline with a high mantle and short horns terminating in a robust spine on the inner side. The valve between the two horns is segmented by pseudoseptae. A hyaline keel at the margin-edge connects the horns and surrounds the slightly undulated valve face. The valve mantle is irregularly and more or less densely areolated $(6-8$ areolae in $10 \mu)$. The central segment of the valve mantle bears few but larger areolae.

Age: Middle Eocene.

Hemiaulus sp. 7

(Plate 21, Figure 12; Plate 24, Figure 9)

Description: Valve oval to lanceolate in outline, with a flat mantle $3-4 \mu$ high. The valve between the two relatively broad horns $(5-7 \mu$ wide) is not segmented by pseudoseptae. There is also no central elevation. The horns are of different length and bent towards the side, at which the shorter horn is positioned. The horns are tipped by a spine at the inner side and a small spine at the outer side. The valve is densely areolated in straight lines. Only one row of areolae finds place on the valve mantle. The number of areolae in $10 \mu$ is $5-6$, slightly decreasing in size towards the apical end of the horns. Irregularly distributed between the areolae are fine punctae. Observed valve length at the base, $20-40 \mu$. For this species holds true, what seems to be a general characteristic also of other species of the genus Hemiaulus the ratio of valve length/length of the horns, in this case: the longer horn is $<1$ in the narrower and $>1$ in the wider specimens.

Hemiaulus sp. (a)

(Plate 20, Figure 6)

Remarks: This species was common in the middle Eocene sediments of Site 356 .

Hemiaulus sp.

(Plate 24, Figure 10)

Hemiaulus sp.

(Plate 21, Figure 5)

Description: Valve lanceolate in outline. The horns decrease gradually in width from their base to their top, which is tipped by a small spine. The valve between the horns is not segmented by pseudoseptae, but slightly convex. The areolae are densely but irregularly distributed on the valve mantle with 6-7 areolae in $10 \mu$, slightly decreasing in size towards the apical end of the horns. Irregularly distributed between the areolae are small punctae. Observed valve length at the base, $30-35 \mu$, height from the base to the apical end of the horns: $30 \mu$. This species differs from Hemiaulus heibergii Cleve (in Peragallo, pl. 94, fig. 3-5) by its fine punctae distributed between the areolae and its more sturdy figure and shorter horns.

\section{Genus HEMIDISCUS Wallich (1860)}

\section{Hemidiscus cuneiformis Wallich (1860)}

(Plate 1, Figure 1)

Description: Hustedt (1930), p. 904, fig. 542; Hendey (1964), p. 94 , pl. 22 , fig. 9 .

Remarks: Included in this highly variable species were specimens belonging to Hemidiscus simplicissimus Hanna and Grant (1926).
Intensive research on the variability of Hemidiscus cuneiformis is necessary to define this species more exactly and differentiate it from similar species.

\author{
Hemidiscus karstenii Jousé (1962) \\ (Plate 1, Figure 3)
}

Description: Abbott (1972), p. 110-112, pl. 1, fig. D-F; Schrader (1976), p. 632, pl. 14, fig. 2.

Remarks: The observed specimens were included in this species because of their asymmetrical valve shape, distinguishing them from the symmetrical Actinocyclus ellipticus. Further study, for example an examination of areolae type, is necessary to clarify the taxonomic position of these two species. The observed specimens were found in Core 358-1, Sections 4-1 (late Pliocene-Pleistocene).

Stratigraphic Record: Miocene of the Norwegian Sea (Schrader and Fenner, DSDP vol. 38, in press). Coscinodiscus elliptiporaCoscinodiscus lentiginosus Zones (McCollum, 1975); Pleistocene of the southwest Pacific (Schrader, 1976); late Miocene-Pleistocene of the South Atlantic (Gombos, in press).

Genus HETERODICTYON Greville (1863)

Heterodictyon sp.

(No illustration)

\section{Genus HYALODISCUS Ehrenberg (1845)}

Hyalodiscus elegans Strelnikova (1974)

(Plate 11, Figures 6, 7; Plate 14, Figure 5)

Description: Strelnikova (1974), p. 51, pl. 2, fig. 1, 2.

Remarks: The size of the observed specimens varied from 15 to $28 \mu$. The delicate structure of the valves of this species disappears with progressive diagenesis. Instead the valve surface becomes more and more coarsely reticulate. This change of the valve surface is shown in the selected specimen in plate 14, fig. 5. This species was found in the middle Eocene samples of Site 356 and the early Oligocene samples of Site 354 (this study).

Age: Cretaceous (Strelnikova, 1974)-early Oligocene (this study).

Genus KISSELEVIELLA Sheshukova-Poretzkaya (1962)

\section{Kisseleviella aff. carina Sheshukova-Poretzkaya in Sheshukova-Poretzkaya and Gleser (1962)} (Plate 32, Figure 20)

Description: Sheshukova-Poretzkaya and Gleser (1962), p. 207, fig. 1a-b, 2; Sheshukova-Poretzkaya (1967), p. 237, pl. 11, fig. 5ac; pl. 60 , fig. $6 a-c$.

Remarks: The specimens found in the middle Eocene of Site 356, are probably not identical with the species described from the Miocene of Japan (Sawamura, 1963), northwest Pacific (Koizumi, 1973a), and the Neogene of Sakhalin (Sheshukova-Poretzkaya, 1967). But too few specimens were found to clear their exact taxonomic position. Similar specimens were found by Hajos (1976) in the early Oligocene of the Southwest Pacific.

\section{Genus KOZLOVIELLA Jousé (1973)}

Kozloviella sp.

(Plate 2, Figure 1)

Description: Valve sickle-shaped and slightly convex, with the hyaline center offset towards the ventral side, stressing the asymmetry about the apical axis. The central area is irregularly shaped. The triangular to quadrangular poroid areolae are arranged in radial lines, submarginally and marginally slightly curved. The areolae are rather constant in size over most of the valve (7-10 in $10 \mu)$. Only within the submarginal zone do they become gradually smaller towards the margin, where there are $14-16$ areolae in $10 \mu$. Equidistant hyaline rows run from the margin towards the center fasciculating the marginal and submarginal rows of areolae and disintegrating in the submarginal zone, so that the central part of the valve is unfasciculated. At their marginal end these hyaline rays have a small labiate(?) process. The margin is distinct but narrow and without ribs. A pseudonodule was not found in the observed specimens. Transapical diameter of the valve is $50-140 \mu$. 
Discussion: This species, which was rare to common in the early Oligocene of Site 354, shows resemblance to the middle Miocene species Kozloviella pacifica (Jousé, 1973). But it differs from the latter in its shape and the size of areolae.

\section{Liostephania stage of Asterolampra spp., Asteromphalus spp.,}

Coscinodiscus tabularis and unknown species

(Plate 18, Figures 1, 2, 4, 5, 7, 8, 10, 12, 13)

The "Liostephania" individuals represent opal molds or casts of frustules of the genera Asterolampra, Asteromphalus, and Coscinodiscus tabularis (Payne, 1922; Hanna and Brigger, 1970; Schrader, 1974, p. 919). They occur in the upper part of the diatom bearing middle Eocene section of Site 356 (Core 6, Section 5 to Core 5 , Section 5) and also in one sample in the lower part of the section $(356-9-2,30-31 \mathrm{~cm})$. The specimen illustrated in Plate 18, Figure 8, is similar to Asterolampra aemulans Grev., illustrated in Schmidt et al. (1874-), pl. 137, fig. 13, which Schmidt interprets as an inner mold of Asterolampra vulgaris.

\section{Genus LIRADISCUS Greville (1865b)}

\section{Liradiscus bipolaris Lohman (1948)}

(Plate 35, Figures 23, 24)

Description: Lohman (1948), p. 165, pl. 8, fig. 5. Valve oblong with parallel to slightly concave sides and a fine ring of marginal spines. Valve face undulated in transapical direction with a central circular depression. Valve face rugated with an irregular, anastomosing arrangement on the convex parts of the valves, but all running toward the center in the surrounding of the central depression. Valve length, $40-50 \mu$; width in the middle, $11 \mu$.

Stratigraphic Record: Lohman (1948) described this species from the middle Miocene from Hammond Well. In this study this species was found in the early Oligocene sediments of Site 354 and the middle Eocene sediments of Site 356. Hajós (1968) found this species in the upper diatom-bearing section of Szurdokpüspöki.

\section{Liradiscus ellipticus Greville (1865d)}

(No illustration)

Description: Greville (1865d), p. 99, pl. 8, fig. 6 .

Remarks: This species was described from Cambridge Estate, Barbados by Greville (1865d). It was found in this study in the middle Eocene of Site 356.

\section{Liradiscus ovalis Greville (1865a)}

(Plate 34, Figures 24,

Description: Greville (1865a), p. 5, pl. 1, fig. 15, 16; Van Heurck (1896), p. 511, fig. 620; Hanna (1927a), p. 114, pl. 19, fig. 4-6.

Remarks: Strelnikova (1974) proved specimens very similar to Liradiscus ovalis to be resting spore(?) of Hemiaulus kittonii. In the middle Eocene of Site 356 heterovalvar specimens also occurred.

Stratigraphic Record: Late Cretaceous of California (Hanna, 1927a); Cambridge Estate of Barbados, late Eocene-early Oligocene (Greville, 1865); and Miocene of California (Hanna, 1927). In this study this species was observed in the middle Eocene of Site 356 and the early Oligocene of Site 354. McCollum (1975) reports it from the early Oligocene of the Southern Ocean.

\section{Liradiscus rotundus (Hajós 1968) (No illustration)}

Description: Hajós (1968), p. 113-114, pl. 28, fig. 7

Remarks: Hajos (1968) describes this species from Szurdokpuspöki. In this study it was found in the early Oligocene sediments of Site 354.

Liradiscus sp. 1

(Plate 37, Figure 12)

Liradiscus sp.

Genus MASTOGLOIA Thwaites in Wm. Smith (1856)

Mastogloia splendida (Gregory) Cleve and Müller (1879) (Plate 33, Figures 13, 14)

Description: Heistedt (1959, p. 463-464, fig. 883).
Genus MELOSIRA Agardh (1824)

Melosira architecturalis Brun (1892)

(Plate 16, Figures 7-12)

Synonym: Cyclotella hannae Kanaya, (1957), p. 82-84, pl. 3, fig. 1014.

Description: Brun in Schmidt et al. (1874-), pl. 177, fig. 45-50.

Remarks: In spite of the areolated valve structure I still keep this species within the genus Melosira until more taxonomic work is done on the definition of this genus. According to the genus description of Round (1970) for Cyclotella, this species cannot be included into the genus Cyclotella. Because what might be interpreted as "Schattenstriche" of Hustedt, in Melosira architecturalis are marginally lain, radial, elevated ribs and not marginal, internal chamber structures, as is characteristic for Cyclotella (Round, 1970; Gasse, 1976).

Melosira concentrica A. Schmidt (1887) in Schmidt et al. (1874) (Plate 4, Figure 12)

Illustration: Schmidt et al. (1887), pl. 176, fig. 47-49.

Description: Valve circular with at least two circular undulations and a central elevation. Elevated connecting bars run from the margin to the submarginal area, between which rings of punctae are visible. Valve diameter is $22 \mu$. Schmidt (1887) described this species from the early Eocene of Mors (Denmark). I found this species in the middle Eocene samples of Site 356.

Discussion: Schmidt proposed the name Paralia concentrica for this species, but also said that the distinction between the genera Melosira and Paralia is questionable and that he disliked the separation of these two genera. For this reason, I have left Schmidt as author for this species.

Age: Eocene.

\section{Melosira subornata A. Schmidt (1892) (Plate 16, Figure 18)}

Illustration: Schmidt et al. (1874-), pl. 178, fig. 50-57.

Remarks: These specimens were found in middle Eocene samples of Site 356. Schmidt's specimens came from Archangelsk and Simbirsk (age not given).

Melosira sulcata (Ehrenberg) Kützing (1844)

(Plate 3, Figure 10; Plate 6, Figures 10, 11; Plate 13, Figure 6; Plate 14, Figure 7; Plate 16, Figures 13-17)

Description: Hustedt (1930), p. 276-278, fig. 118-120.

Remarks: The variability of specimens listed under this name is shown in the illustrations.

Age: Not diagnostic.

Melosira westii W. Smith (1856)

(Plate 14, Figure 6; Plate 15, Figure 11; Plate 18, Figure 11)

Synonym: Hercotheca sp. a Kanaya (1957).

Pseudopodosira westii (W. Schmidt) in Sheshukova-Poretzkaya and Gleser (1964).

Description: Hustedt (1930), p. 268-269, fig. 113; Van Heurck (1881), pl. 91, fig. 11, 12; Proschkina-Lavrenko (1974), pl. 18, fig. 7; Hajós and Stradner (1975), p. 924-925, pl. 1, fig. 3, 4; pl. 19, fig. $1,2,4$.

Remarks: The observed specimens varied in size from $15-50 \mu$ in diameter and were found in the middle Eocene sediments of Site 356.

Stratigraphic Record: Cretaceous-Recent. Upper Cretaceous of the southwest Pacific (Hajos and Stradner, 1975); and Paleogene (Sheshukova-Poretzkaya and Gleser, 1964, 1969; Gleser et al., 1965).

Melosira sp. 1

(Plate 7, Figures 7-9)

Description: Valve circular with strongly silicified long submarginal processes, which bifurcate at the top. Valve mantle coarsely areolated (10-12 areolae in $10 \mu)$. These areolae are arranged in straight double-rows. At the base of the mantle there may be elongated structureless "pedal segments" (alveoles) formed by the continuing ribs separating the double rows of areolae in the upper part of the mantle. 
Discussion: Whether this species is identical with Skeletonema barbadense Greville (1865) from Barbados (see also Jousé, 1974) cannot be determined as the type material was not studied. Most of the specimens observed in the middle Eocene and early Oligocene sediments of Sites 356 and 354 do show areolation. It could not be determined whether missing areolation was due to diagenesis or primary structure, since only a few specimens were found.

Age: Middle Eocene-early Oligocene.

\section{Genus MONOBRANCHIA Schrader in Schrader and Fenner} (in press, b)

\section{Monobranchia simplex Schrader in Schrader and Fenner (in press)} (Plate 20, Figure 15)

Description: Schrader and Fenner (in press, b), p. 174, pl. 41, fig. $15,16,18,20$.

Stratigraphic Record: Middle Eocene-late Oligocene of the Norwegian Sea (Schrader and Fenner, in press, a) and middle Eocene (this paper).

\section{Monobranchia unicornuta (Brun) Schrader and Fenner (in press)} (Plate 20, Figure 16)

Basionym: Hemiaulus unicornutus Brun (1892), p. 175, 176, pl. 24, fig. 3 .

Description: Brun (1892), p. 175-176, pl. 24, fig. 3; Schrader and Fenner (DSDP vol. 38, in press), p. 175, pl. 42, fig. 13, 14.

Stratigraphic Record: Late Eocene-middle Oligocene of the Norwegian Sea (Schrader and Fenner, in press, a); late Eocene of Oamaru (Brun, 1890-1893), and middle Eocene of the South Atlantic (this paper).

\author{
Monobranchia sp. \\ (Plate 20, Figure 14) \\ Monobranchia sp. 1 \\ (Plate 20, Figure 19)
}

\section{Genus NAVICULA Bory (1822)}

\section{Navicula udintsevii Schrader and Fenner (in press, b)}

(No illustration)

Description: Schrader and Fenner (in press, b), pl. 22, fig. 33; pl. 24, fig. 2 .

Stratigraphic Record: Late Eocene of Site 337, Norwegian Sea (Schrader and Fenner, in press, a, b), and early Oligocene of Site 354 (this study).

Navicula sp. 1

(Plate 33, Figure 6)

Navicula sp. 2

(Plate 33, Figure 2)

Genus NITZSCHIA Hassall (1845)

\section{Nitzschia interrupta Heiden in Heiden and Kolbe (1927)} (No illustration)

Description: Heiden and Kolbe (1927), p. 665, pl. 7, fig. 150; Kolbe (1955), p. 174, pl. 2, fig. 25-27; Schrader (1974), p. 914, pl. 15, fig. 1-7. $(1974)$

Age: Late Miocene-Pleistocene of the Indian Ocean in Schrader

\section{Nitzschia kerguelensis O'Meara Hasle (1972)}

(No illustration)

Description: Hasle (1965), p. 14-18, pl. 4, fig. 11-18; pl. 7, fig. 9 (as Fragilariopsis kerguelensis O'Meara); Fenner et al. (1976), p. 764, pl. 2 , fig. $19-30$.

\section{Nitzschia aff. miocenica Burckle (1972)}

(Plate 32, Figures 22, 23)

Description: Burckle (1972), p. 240-241, pl. 2, fig. 10-15.

Remarks: The illustrated specimens were found in the late Miocene sediments of Site 358 .

\section{Nitzschia panduriformis Gregory (1857) \\ (Plate 32, Figures 27-29)}

Description: Peragallo and Peragallo (1897-1908), p. 268, pl. 70, fig. 3-5; Hendey, (1964), p. 279.

Remarks: Valve broadly elliptic with a narrowing central part and subrostrate apices. There are 12-14 areolae and transapical striae in $10 \mu$. The striae are curved near the apices. At the apices the areolae also become smaller. The sulcus is strongly marked. Keel punctae are present equivalent to the number of striae. Observed valve length is $42-52 \mu$, width, $17-18 \mu$. These Pleistocene specimens differ from the Recent, benthic species by their coarser areolation and the number of keel-punctae being equivalent to the number of striae.

Nitzschia pseudocylindrica Schrader in Schrader and Fenner (in press) (No illustration)

Description: Schrader and Fenner (in press, b), pl. 1, fig. 35, 12, 15-18.

Age: Late Miocene-Pleistocene. Schrader in Schrader and Fenner (in press, a) reports this species from the Pliocene of the Norwegian Sea.

\section{Nitzschia ritscheri (Hustedt) Hasle (1972a) \\ (No illustration)}

Description: Hasle (1965), p. 20-21, pl. 1, fig. 20; pl. 4, fig. 1-7; pl. 7, fig. 8; Fenner et al. (1976), p. 777, pl. 3, fig. 1-12.

\section{Nitzschia separanda (Hustedt) Hasle (1972a)}

(No illustration)

Description: Hasle (1965), p. 26-27, pl. 9, fig. $7-10$; pl. 10 fig. 1; Fenner et al. (1976), p. 777, pl. 1, fig. 1-16; pl. 2, fig. 23-29.

Age: Pliocene(?)-Pleistocene.

\section{Nitzschia sicula? (Castr.) Hustedt (1958)}

(No illustration)

Description: Valve lanceolate with slightly convex sides and broadly rounded apices. The apical part is elongated. The number of transapical striae is $14-15$ in $10 \mu$. The intercostal membranes have two transapical rows of punctae (about 26 punctae in $10 \mu$ ). The transapical striae are straight. Valve length, $60 \mu$; width, $7 \mu$. The observed specimens differ from the species by having finer punctation, finer transapical striation and elongated apical ends.

Age: Pliocene?-Pleistocene.

Nitzschia sp. 1

(Plate 32, Figure 25)

Description: Valve lanceolate with obtuse, slightly elongated apices. There are 15-16 transapical striae in $10 \mu$ and only one row of poroids in each intercostal membrane, with 28 poroids in $10 \mu$. The number of keel-punctae is identical with the number of transapical striae. At the one end the keel punctae turn from the margin towards the central part of the valve end.

Age: Late Miocene-Pleistocene.

Nitzschia sp. 2

(Plate 32, Figure 24)

Description: Valve sublinear with broadly rounded apices. The transapical costae are oblique and number 6-7 in $10 \mu$. The intercostal membranes show two rows of poroids. In some specimens an intercostal membrane with only one row of poroids may occur. There are 14-15 poroids in $10 \mu$. The transapical costae are curved at the apices, at both ends to the same side. Valve length, 30-55 $\mu$; width, 8 $10 \mu$. This species is close to Nitzschia peragalii Hasle, but differs from the latter by shorter but wider valves. It differs from Nitzschia cylindrica Burckle by its coarser transapical striation.

Age: Pleistocene.

Nitzschia sp.

(Plate 32, Figure 26)

Remarks: This species is very close to Nitzschia porteri in valve shape, but differs from the latter by its finer areolation, 16 areolae in $10 \mu$. 
Genus PEPONIA Greville (1863)

Peponia aff. barbadensis Greville (1863) (No illustration)

Description: The valve has a subcircular, convex central part and two conical, laterally and upward projecting elevations which are separated from the central part by a hyaline pseudoseptum and terminate in an open hole. The central part is widest in direction perpendicular to the axis of the two elevations. The areolation is the same on the central part of the valve and the elevation. The areolae are densely packed and arranged in irregularly radiating lines, 9-13 in $10 \mu$. In the center one small spine is present. Observed valve diameter without the laterally projecting elevations, $15-35 \mu$. The few specimens found in the middle Eocene of Site 356 harmonize in size and areolation with the specimens observed in the middle late Eocene of Site 339 (Schrader and Fenner, in press, a, b) and the specimens illustrated from the late Eocene of the Ukraine (Gleser and Sheshukova-Poretzkaya, 1967, 1969). But these specimens are much finer areolated than the specimen illustrated in the species description of Greville (1863), which is, according to him, not unfrequent in the Eocene of Barbados and has only 3-4 areolae in $10 \mu$.

Age: Middle-late Eocene.

Peponia sp. 1

(Plate 31, Figure 6)

Description: Valve subrounded in outline with the two laterally and upward projecting elevations at two opposing sides, set off by a hyaline pseudoseptum. The central part of the valve is broadest in the axis of the two elevations: $37 \mu$ measured without the elevations. The polygonal areolae are irregularly distributed with a circle of small spines in the center of the valve. There are 6-8 areolae in $10 \mu$. On the elevations the areolae show a tendency to linear arrangement and are much smaller, 12-14 areolae in $10 \mu$.

Age: Middle Eocene.

\section{Genus PLOIARIA Pantocsek (1889)}

Ploiaria petasiformis Pantocsek (1889) (Plate 26, Figure 9)

Synonym: Hemiaulus? petasiformis Pantocsek (1889), vol. I, p. 50 , pl. 29 , fig. 295 .

Description: Pantocsek (1889), vol. II, p. 83, pl. 28, fig. 403, 405; Van Heurck, Treatise (1896), p. 457, fig. 186.

Stratigraphic Record: Pantocsek $(1886,1889)$ describes this species from Szakal, Hungary; Miocene after Hendey (1972); middle Eocene of Site 356 (this study).

\section{Genus PODOSIRA Ehrenberg (1840)}

\section{Podosira polita Hanna and Grant (1926)} (Plate 25, Figures 7, 8)

Description: Hanna and Grant (1926), p. 164, pl. 20, fig. 5.

Remarks: The observed variation in diameter was $22-29 \mu$. There are 14-16 areolae in $10 \mu$. In addition to Hanna and Grant's description, all specimens had a marginal process (labiate process?) and also regularly arranged submarginal pores or spines (in most cases 3 ), lying half way between the central area and the margin, in the middle of the beads. This makes a systematic position within the genus Podosira questionable. It was nevertheless, but hesitatingly, included in the genus Podosira, because of the typical umbilicus and the segmentation. A revision of this genus is badly needed.

Stratigraphic Record: Eocene-Miocene. This species is quite common in the early Oligocene of Site 354, but single specimens were also found in the middle Eocene of Site 356. Hanna and Grant (1926) reported this species from the Miocene of Mexico.

Genus PSEUDODIMEROGRAMMA Schrader in Schrader and Fenner (in press, b)

Pseudodimerogramma sp. 1

(Plate 28, Figures 3, 4, 9, 10)

\section{Genus PSEUDOPODOSIRA Jousé}

Pseudopodosira aspéra Jousé, 1949

(Plate 10, Figures 4, 5)

Illustration: Proshkina-Lavrenko (1974), v. I, pl. 13, fig. 4

Remarks: Only a few badly preserved specimens were found in the middle Eocene samples of Site 356.

Age: Not yet determined.

Pseudopodosira bella Gleser and Posnova (1964)

(Plate 10, Figures 2, 3, 6-8)

Description: Gleser and Posnova (1964), p. 60, 61, pl. 1, fig. 2, text fig. 1 .

Remarks: The observed valve diameters varied between $10 \mu$ and $20 \mu$. The segments surrounding the central elevation vary from 7 to 18. Diagenesis reduces the relief of the specimens (see Plate 10, Figures 2, 3, 8), and enlarges and unites the subcentral segments (Plate 10, Figure 8). Pseudopodosira bella is very common in the middle Eocene sediments of Site 356. It was also found in the early Oligocene of Site 354 and is reported by Gleser and Posnova (1964) from the marine Eocene of west Kazakstan and from the Ukraine by Gleser et al. (1965) and Gleser and Sheshukova-Poretzkaya (1968). A very closely related specimen, but with a ring of round elevations around a central one, was found in the late Oligocene (Sceptroneis pupa Zone) of Site 338 (Norwegian Sea), where it was described as Melosira species (pl. 27, fig. 5).

Age: Eocene.

\section{Pseudopodosira elegans? Sheshukova-Poretzkaya and Gleser 1964} (Plate 18, Figure 9)

Description: Sheshukova-Poretzkaya (1967), p. 178, pl. 24 , fig. 3; pl. 25, fig. 4; Koizumi, J. (1972), p. 352, pl. 43, fig. 3, 4.

Remarks: The observed specimens were much larger: $45-50 \mu$, than the ones described by Koizumi (1972). This species was found in the middle Eocene samples of Site 356.

\section{Pseudopodosira sp.}

(Plate 10, Figure 9)

\section{Genus PSEUDOPYXILLA Forti (1909)}

Pseudopyxilla dubia (Grunow) Forti (1909)

(Plate 14, Figure 9; Plate 17, Figures 1-6)

Description: Forti (1909), p. 12, pl. 1, fig. 1-3; Kanaya (1957), p. 114 , pl. 8 , fig. 10 .

Stratigraphic Record: Cretaceous of California (Hanna, 1927); early Eocene of Mors, Jutland (Van Heurck, 1881; Forti, 1909; Tsumura, 1959); late Eocene of California (Kanaya, 1957); late Eocene of the Norwegian Sea (Schrader and Fenner, in press a, b); middle Eocene of Site 356 (this paper).

\section{Pseudopyxilla sp. \\ (Plate 17, Figure 7)}

Description: Valve cylindrical with a conical end. Valve surface covered with rugae in apical direction. Valve diameter $29-31 \mu$. This species is similar in shape to Pseudopyxilla rossica and Pseudopyxilla dubia, but differs from both by its rugated surface. This species was found in the middle Eocene at Site 356.

Genus PSEUDORUTILARIA Grove and Sturt (1886)

See also: Schrader and Fenner (in press b).

Pseudorutilaria monomembranacea Schrader in Schrader and Fenner (in press b)

(Plate 26, Figures 6, 8)

Description: Schrader in Schrader and Fenner (DSDP vol. 38, in press), pl. 22, fig. 1-6. wide.

Remarks: The observed specimens were $29-50 \mu$ long and $4-7 \mu$

Stratigraphic Record: Late Eocene of the Norwegian Sea (Schrader and Fenner, in press, a, b) and middle Eocene of Site 356 (this paper). 
Genus PSEUDOSTICTODISCUS Grunow in Van Heurck (1880. 1885)

Pseudostictodiscus picus Hanna

(Plate 1, Figure 10)

Synonym: Pseudostictodiscus angulatus Grunow var. in Schmidt et al. (1874-), pl. 74, fig. 24

Illustration: Proschkina-Lavrenko (1974), pl. 16, fig. 11.

Stratigraphic Record: Late Eocene of the Norwegian Sea (Schrader and Fenner, in press, a, b), Barbados (Schmidt et al., 1874-, pl. 74), and middle Eocene of Site 356 (this paper).

\section{Genus PTEROTHECA (Grunow) Forti (1909)}

Pterotheca aculeifera Grunow (1880)

(Plate 17, Figures 8-21)

Synonyms: Pterotheca sp. 2, McCollum (1975), p. 535, pl. 10, fig. 10. Pterotheca crucifera in Hajós and Stradner (1975), pl. 12, fig. 8, 22; not Pterotheca crucifera Hanna (1927) Pterotheca sp. A. Gombos (in press), p. 75, pl. 23, fig. 3, 4. Pterotheca sp. in Schrader and Fenner (in press, b), pl. 43, fig. 5-7.

Description: Van Heurck (1896), p. 430, fig. 151; Kanaya (1957), p. 109-110, pl. 8, fig. 1, 2 .

Remarks: The ratio of valve-diameter to pervalver axis is quite variable. The illustrated specimens were grouped as: the elongated type, Plate 17, Figures 13-15; the type with twisted ribs, Plate 17, Figure 20; the type without ribs, Plate 17, Figure 17; the type with pervalver axis only $1 / 3$ longer than the diameter at the base, Plate 17 , Figures 10,18; the type with a pervalver axis more than $1 / 3$ longer than the valve-diameter at the base, Plate 17, Figures 9, 21; and the type with only few, thick ribs, Plate 17, Figure 19. All these types were counted and listed separately, but they all occurred in the same samples. No evolutionary trend was visible, so they were all included into Pterotheca aculeifera. Some specimens had a very short pervalver axis in this characteristic approaching Pterotheca crucifera Hanna (1927). But also the types with an elongated pervalver axis, which were also found in the upper Eocene of the Norwegian Sea (Schrader and Fenner, in press, a, pl. 43, fig. 7) and the South Atlantic (Gombos, in press, Pterotheca sp. A.) could not be separated from the species.

The number and direction of the ribs is also highly variable, from $0-16$. They run from the margin to the apex in straight, or curved, or even in spiral lines, which are in some specimens interrupted; some specimens did not even have ribs. The distance of the insertion of the branches at the longspine from the apex is also quite variable.

Stratigraphic Record: Upper Cretaceous-early Oligocene. Upper Cretaceous of West Siberia (Strelnikova, 1974); upper Cretaceous of the southwest Pacific Ocean (Hajós and Stradner, 1975); Eocene of California (Kanaya, 1957); Eocene of the South Atlantic (Gombos, in press); early Eocene of Mors (Denmark) (Tsumura, 1963; Benda, 1972); early Oligocene of the southwest Pacific (Hajós, 1976; McCollum, 1975, as Pterotheca sp. 2). (For a more extensive list see Kanaya, 1957, p. 110.) Middle Eocene of Site 356 (this study).

\section{Pterotheca gracillima n. sp.}

(Plate 12, Figures 5, 6)

Description: Valves highly cylindrical, with a convex upper part and a circular outline. On top of the center is a long bifurcate spine. At the transition between convex and cylindrical part (mantle) of the valve is a ring of small spines. The mantle is very finely punctate (2022 punctae in $10 \mu$ ). The punctae are of constant size on the whole valve and are arranged in straight radial double-rows. At the base of the mantle there is a ring of relatively large pedal segments (14 "segments" in $10 \mu$ ). Valve diameter is $7-8 \mu$, height is $8-10 \mu$ without spine.

Discussion: This species was also observed in the late Eocene of Site 338 (Norwegian Sea) and was named Pterotheca sp. 3. But as the same species seems also to be characteristic of the middle Eocene of the southern Atlantic (Site 356) this species was established. The only similar form observed in the literature is the upper Cretaceous Stephanopyxis schulzii Steinecke (Strelnikova, 1974). But this species is much coarser areolated with many small scattered spines on the valve surface besides the two subcentral long spines.

Holotype: Plate 12, Figure 5 from DSDP Leg 39, Sample 356-7-6, $30-31 \mathrm{~cm}$.
Paratypes: Plate 12, Figure 6 from DSDP Leg 39, Sample 356-6$4,30-31 \mathrm{~cm}$; Plate 35, Figures 17 and 18 from DSDP Leg 38, Sample $338-27, \mathrm{CC}$

Age: Middle-late Eocene.

\section{Pterotheca kittoniana var. kamtschatika Gaponov (1927)}

(Plate 9, Figures 2, 5)

Illustration: Sheshukova-Poretzkaya (1967), pl. 39, fig. 3.

Description: Valve circular, convex. Inner part of the valve surrounded by a polygonal strong siliceous ring. In each inner corner of the polygonal ring is one large spine. Smaller spines (2-15) are scattered over the central part of the valve.

The taxonomical status of this species is unsolved. Its membership in the Diatomaceae is questionable.

\section{Pterotheca uralica Jousé (1949)}

(Plate 17, Figure 22)

Description: Strelnikova (1974), p. 115, pl. 57, fig. 27-30.

Stratigraphic Record: Upper Cretaceous (Strelnikova, 1974); middle Eocene (this paper).

Pterotheca sp. 4 Fenner in Fenner and Schrader (in press b) (Plate 12, Figure 4)

Description: This species is very similar in shape and size to the Pterotheca gracillima, but it differs from the latter in having slightly larger punctae (12-14 punctae in $10 \mu)$ that are arranged in simple radial rows. A circle of small spines at the transition between the cylindrical and convex part of the valve is missing. A central spine at the top is present. The segments at the base are larger (approx. 10 in $10 \mu$ ) than in the Pterotheca gracillima.

This species was also found in the late Eocene sediments of the Norwegian Sea.

Age: Middle-late Eocene.

Pterotheca sp. 1

(Plate 17, Figure 23)

Description: This very robust species has a very thick, spinous, curved long spine on its apex. Spine diameter is $3-4 \mu$. Valve diameter at the base, $11-12 \mu$. Pervalver axis, $23 \mu$. The mantle is relatively high, $5 \mu$, with irregularly distributed punctae on it and a knoppy upper rim with two spines on opposite sides. The cylindrical and convex part of the upper part of the valve is ornamented by short ribs arranged in the connecting direction from the margin to the apex.

Discussion: No similar species was observed in the literature.

Pterotheca sp.

(Plate 12, Figure 3)

Description: This species differs from Pterotheca gracillima by its elongated cylindrical mantle. Valve height is $13-15 \mu$, valve diameter, $8 \mu$. The punctae are arranged in straight lines on the valve mantle, approx. 24 in $10 \mu$. A ring of small spines between the cylindrical mantle and the convex part of the valve is present; a large central spine is located at the top. At the base the valve-diameter is constricted to approx. $5 \mu$. This part of the valve is irregularly punctate. The margin has normal valve diameter. Marginal segments could not be seen.

Age: Middle Eocene.

\section{Genus PYRGUPYXIS Hendey (1969)}

\section{Pyrgupyxis caput-avis (Brun) Hendey (1969)}

$$
\text { (Plate 20, Figures 2, 3) }
$$

Description: Brun in Forti (1909), p. 19-20, pl. 2, fig. 10; Tsumura (1959), p. 194, pl. 1, fig. 1, 2; Brun (1893-96), p. 242, pl. 19, fig. 11.

Stratigraphic Record: Late Eocene of Oamaru (Brun, 1893-96; Forti, 1909; Tsumura, 1963) and middle Eocene of this paper.

Pyrgupyxis caput-avis (Brun) Hendey var. gracilis Tempère in Forti (1909)

(Plate 20, Figure 17)

Description: Forti (1909), p. 12, 19, 20, pl. 2, fig. 9.

Stratigraphic Record: Late Eocene of Oamaru (Tempère in Forti, 1909) and middle Eocene (this paper). 


\section{Pyrgupyxis gracilis (Tempère and Forti) Hendey (1969)}

(Plate 19, Figures 1-3)

Description: Forti (1909), p. 26, pl. 2, fig. 5.

Remarks: Valve length variable, $95-135 \mu$; valve diameter from 7 $9 \mu$. The number of areolae is rather constant on each valve, but varies in the observed population (3-5 areolae in $10 \mu$. The areolae only decrease in size at the very end of the valve to 6-8 areolae in $10 \mu$. In some specimens a slight decrease in size was observed in the basal part of the valve, but is not associated with a broadening of the valve. The small lateral spine lies at the base of the narrowing apical part of the valve; the apical part of the valve is $1 / 5$ to $1 / 6$ of the valve length.

Stratigraphic Record: Middle Eocene of Site 356 (this paper), Eocene of the Volga district, late Eocene of west Siberia and west Kazakstan, the North-Donez Basin (Jousé, 1955; Gleser et al., 1965), Eocene of the equatorial Atlantic, DSDP Site 13, Core 3 (Gleser and Jousé, 1974), Barbados (Forti, 1909; Hanna and Brigger, 1964).

\section{Pyrgupyxis gracilis (Tempère and Forti) Hendey var. buccinalis Forti (1909) \\ (Plate 19, Figures 12, 13, 18)}

Description: Forti (1909), p. 19, 20, pl. 2, fig. 6.

Remarks: This variation differs from the species by its more or less gradually widening valve from the apex to the base and its having a larger diameter than the species. The length of the apical part of the valve upwards from the lateral spine is about $1 / 3$ of the valve length. The observed valve length is $90-137 \mu$; the valve diameter at its base is $12-20 \mu$. The number of areolae is constant on each valve decreasing only in the apical part from the lateral spine towards the apical end of the valve. In most specimens the areolae also slightly decrease in size near the base where short intercalated rows of areolae disturb the regular linear areolation pattern. Observed size of areolae is $2-4$ areolae in $10 \mu$, and 4-6 areolae in $10 \mu$ near its base and in the apical part between lateral spine and apical end of the valve.

Stratigraphic Record: Late Eocene of Barbados (Forti, 1909); late Eocene of the southwestern Pacific Ocean (Hajos, 1976); and middle Eocene of the South Atlantic (this paper).

\section{Pyrgupyxis gracilis (Tempère and Forti) Hendey var. saratoviana (Pantocsek) Hendey (1969)}

(Plate 19, Figures 4-7; Plate 37, Figures 19, 20)

Synonym: Hemiaulus? saratoviamus Pantocsek (1889), vol. 2, p. 83 , pl. 13, fig. 235 .

Description: Forti (1909), p. 19, 20, pl. 2, fig. 7, 8.

Remarks: This variation differs from the species only in a slightly broadened basal part of the valve, within which the loculi are somewhat denser packed than in the upper part of the valve and may also be slightly smaller. Transitional forms to Pyrgupyxis prolongata were observed. Further studies on the variability of these two forms are necessary to clarify the taxonomy. Observed valve length, 110$150 \mu$; valve diameter, $11-17 \mu$; size of areolae, $3-5$ in $10 \mu$.

Stratigraphic Record: Kusnetzk, USSR by Pantocsek (1889); Eocene of the South Atlantic, Hendey (1969); late Eocene of Oamaru, Forti (1909), late Eocene-early Oligocene of the southwestern Pacific Ocean, Hajós (1976); and middle Eocene (this paper).

\section{Pyrgupyxis johnsoniana (Forti) Hendey (1969)}

(Plate 19, Figure 11; Plate 20, Figure 1; Plate 37, Figure 18)

Synonym: Pyxilla johnsoniana Grev, in Grove and Sturt (1887), p. 71, pl. 5, fig. 10; not Pyxilla johnsoniana Greville (1865a) p. 2, pl. 1, fig. 6. Pyxilla johnsoniana Grev. var. corniculum Brun in Brun (1890-1893), p. 243, pl. 19, fig. 12, 13. Pyxilla reticulata Grove and Sturt (1887), p. 145, pl. 13, fig. 50.

Description: Forti (1909), p. 19, 20, pl. 2, fig. 2; Ross and Sims (1973), p. 100, pl. 1, fig. 7, 8; Grove and Sturt (1887), p. 71, pl. 5, fig. 10.

Remarks: Observed valve length is $65-90 \mu$. Valve diameter at its base is $17-19 \mu$. Number of areolae is 6-7 in $10 \mu$. Basal part of the valve is distinctly inflated. Excluding the smaller areolae at the apical end the areolae are of the same size over the whole valve and are arranged in straight lines. The areolae are finely punctate (compare pl. 19, fig. 11). The observed specimens harmonize in shape, size, and size of areolae with the specimens illustrated by Forti (1909) and Ross and Sims (1973). Under this species also valves, which were named Pyxilla reticulata by Grove and Sturt (1887) were listed and counted. Hajós (1976) could prove by findings of complete frustules that Pyxilla reticulata is just the lower valve of Pyrgupyxis johnsoniana. That these species are synonymous was already suggested by McCollum (1975).

Stratigraphic Record: Late Eocene of Oamaru (Grove and Sturt, 1887; Forti, 1909; Ross and Sims, 1973), late Eocene of the South Atlantic (Gombos, in press); late Eocene-early Oligocene of the southwestern Pacific Ocean (Hajós, 1976); middle Eocene of the South Atlantic Ocean (this paper); early Oligocene of the Southern Ocean (McCollum, 1975), and late Eocene of the North Donez Basin (Gleser et al., 1965).

\section{Pyrgupyxis johnsoniana (Forti) Hendey (1969) var. (Plate 20, Figure 18)}

Description: This variation differs from the species by its less broadly inflated basal part and the more curved apical part between the lateral spine and the apical end. Observed valve length is $95-124 \mu$; valve diameter at its base is $13-19 \mu$. The number of areolae is rather constant on each valve, but varied in the observed specimens from 4-6 in $10 \mu$, decreasing in size near the apical end.

\section{Pyrgupyxis prolongata (Brun) Hendey (1969) (Plate 19, Figure 8)}

Description: Brun (1890-93), p. 176, pl. 24, fig. 7.

Stratigraphic Record: Early Eocene-late Oligocene. This species was described first from Brun (1890-93) as a rare fossil form from New Zealand. It was also reported by Gombos (in press) from late Eocene to late Oligocene of the South Atlantic and by McCollum (1975) from the early Oligocene of the Southern Ocean. In this study it was found in the middle Eocene sediments of Site 356.

Remarks: This species is distinguished from Pyrgupyxis gracilis (Temp. and Forti) var. saratoviana by its broadly inflated basal part, which is also much finer areolated (5-6 areolae in 10 $\mu$ ) than the elongated apical part of the valve (only about 4 areolae in $10 \mu$ ). Only at the very apical end the areolae again decrease in size to 6-8 areolae in $10 \mu$. Another mark of distinction to Pyrgupyxis gracilis var. saratoviana is the position of the lateral spine, which is in Pyrgupyxis prolongata approximately $2 / 3$ way from the base towards the apex and is $3 / 4$ to $4 / 5$ way from the base towards the apex in Pyrgupyxis gracilis var. saratoviana.

\section{Pyrgupyxis sp. 1}

(Plate 19, Figures 14-16)

Pyrgupyxis sp. 2

(Plate 19, Figure 17)

Pyrgupyxis sp.

(Plate 19, Figure 9)

\section{Genus RHAPHONEIS Ehrenberg (1884)}

\section{Rhaphoneis angulata Fenner in Schrader and Fenner (in press, b)} (No illustration)

Description: Schrader and Fenner (in press, b), pl. 7, fig. 7; pl. 23, fig. 28-30.

Stratigraphic Record: Middle-late Oligocene of the Norwegian Sea (Schrader and Fenner, in press, a, b). Middle Eocene of Site 356 (this paper).

\section{Rhaphoneis angustata Pantocsek (1886)}

$$
\text { (Plate 29, Figure 6) }
$$

Description: Pantocsek (1886), v. I, p. 33, pl. 11, fig. 97; pl. 30, fig. 313; Lohman (1948), p. 180-181, pl. 11, fig. 11; Lohman (1974), p. 352 , pl. 5, fig. 14; Andrews (1975), p. 203-204, pl. 1, fig. 5, 6 .

Stratigraphic Record: Early-late Miocene. Pantocsek (1886) reported this species from the Torton of Hungary (localities Kekkö, Szakal), Lohman $(1948,1974)$ found this species in the Miocene of Maryland (Calvert Formation) and the lower middle Miocene of Trinidad (Cipero Formation). Andrews (1975) reports this species also from the Choptank Formation of the Calvert Cliffs Maryland. In this study this species was found in the early Oligocene sediments of Site 354 (displaced?). 
Rhaphoneis aff. surirella Grunow in Van Heurck (1880) (No illustration)

Description: Hustedt (1959), p. 173-174, fig. 679.

Remarks: These Pliocene specimens differ from the species by a much finer areolation and striation.

\section{Rhaphoneis sp. 1}

(Plate 29, Figure 3)

Description: Valve lanceolate with broadly rounded apices. Valve length, $20-25 \mu$; width, $6-7 \mu$. The hyaline axial area is about $1 \mu$ wide in the middle of the valve, narrowing toward the apices. The striae are consistent across the axial area. They are more or less straight in the middle of the valve and become slightly curved towards the apices. The number of transapical striae in $10 \mu$ is $9-10$. The number of areolae is $15-17$ in $10 \mu$.

Age: Middle Eocene.

Rhaphoneis sp.

(No illustration)

Remarks: Under this name unidentified specimens of the genus Rhaphoneis were listed.

Resting spores

Resting spore (1)

(Plate 34, Figure 33)

Resting spore

(Plate 37, Figures 4, 5, 9)

Resting spore

(Plate 34, Figure 23)

Resting spore

(Plate 34, Figure 27)

Resting spore

(Plate 34, Figure 32)

Genus RHIZOSOLENIA Ehrenberg (1841)

Rhizosolenia hebetata var. subacuta Grunow (1884)

(Plate 20, Figures 10, 11)

Description: Grunow (1884), p. 96, pl. 5, fig. 49, 50.

Age: Early Oligocene-Pliocene. Few specimens were found displaced? in the middle Eocene sediments of Site 356.

Rhizosolenia aff. styliformis Brightwell (1858)

(No illustration)

Description: Hustedt (1930), p. 584-588, fig. 333.

Remarks: The observed specimens differ in the form of the apical spine from the species. These specimens were found in the middle Eocene sediments of Site 356, displaced?

Rhizosolenia sp. e

(Plate 20, Figure 12)

Description: Koizumi (1968), p. 217, pl. 34, fig. 26; Koizumi (1973a), p. 833, pl. 5, fig. 39.

Remarks: Koizumi (1973a) found this species in the middle and upper Miocene of the North Pacific. In this study it was found in the middle Eocene sediments of Site 356. In the Norwegian Sea material I observed this species in the middle Oligocene sediments of Site 338.

\section{Rhizosolenia sp. 1}

(Plate 20, Figure 9)

Rhizosolenia sp. (Plate 20, Figure 13)

Genus RIEDELIA Jousé and Sheshukova-Poretzkaya (1971)

The definition of this genus given by Schrader and Fenner (in press, b) was used, but with the addition that a further criterion typical for this genus is the central conical projection which has an open hole (pseudonodulus?) on its top. Such a projection was observed in the material examined in this study and can also be seen in the older illustrations. Such a pseudonodulus? has not been observed in the specimens of the genus Hemiaulus.

\section{Riedelia alata (Greville) Schrader and Fenner (in press, b)}

(Plate 26, Figures 1, 2)

Description: Greville (1865b), p. 31, pl. 3, fig. 14; Grunow (1884), p. 62; Schmidt et al. (1874-), pl. 143, fig. 15, 20-22.

Remarks: This very characteristic species is quite variable in its length/width ratio as was already stated by Greville (1865b). The observed length from the valve base to the small spines at the end of the horns is $42-56 \mu$, the width at the valve base is $20-42 \mu$. The tendency in the length/width ratio tends from narrow specimens with long projections in the lower middle Eocene to broad specimens with short projections in the upper middle Eocene, thus supporting the observations of Greville (1865b). The narrower specimens show an irregular arrangement of areolae on their mantle, while the broader specimens show an arrangement of the areolae in straight lines. Specimens which are affected by beginning diagenesis show an irregular network of ribs interfingering with the areolae. The central conical projection has an open hole on its top (pseudonodulus?). An illustration of a species Hemiaulus szaboi Pantocsek, which is very similar to Hemiaulus alatus Greville was found in Pantocsek, 1889 , pl. 14, fig. 250. But to prove the identity of these two species, studies of the material from Bremia (age?), from which Hemiaulus szaboi was described, are necessary.

Stratigraphic Record: Greville (1865b) described this species from Barbados; from the early Eocene of Mors (Jutland) Greville (1865b) and Benda (1972) reported this species. It was found in the upper part of the middle Eocene of DSDP Site 356 in this study.

\section{Riedelia altar (Brun) Schrader and Fenner (in press, b)} (Plate 25, Figures 3, 13)

Description: Brun (1896), v. 2, p. 238, pl. 20, fig. 19, 20

Remarks: Brun described this species from the Chimborazo; Mount Hillaby (age?). In this study it was found in the lower parts of the middle Eocene sediments of Site 356. Gombos (in press) found this species in the late Paleocene of the South Atlantic.

\section{Riedelia borealis Sheshukova-Poretzkaya (1971)} (Plate 26, Figures 12, 18)

Description: Jousé and Sheshukova-Poretzkaya (1971). Proschkina-Lavrenko (1974), v. 1, pl. 39, fig. 5.

Remarks: This species was found commonly in the middle Eocene samples of Site 356.

\section{Riedelia claviger (A. Schmidt) Schrader and Fenner (in press, b)} (Plate, 25, Figure 11; Plate 37, Figure 17)

Description: Schmidt et al. (1874-), pl. 143, fig. 5, 6; Hanna (1927a), p. 113, pl. 18, fig. 8; Hanna (1931), pl. A, fig. 3 .

Stratigraphic Record: Middle Eocene of Site 356 (this study), late Eocene of Oamaru (A. Schmidt, 1889), late Eocene of the North Donez Basin (Gleser et al., 1965) and the northeastern margin of the Ukrainian Crystalline Massif (Gleser and Sheshukova-Poretzkaya, 1968, as Hemiaulus tenuis). Tertiary of the south Atlantic (Gombos, in press) and from the Kreyenhagen Shale and the Phoenix Canyon, California (Hanna, 1931, 1927a).

Riedelia longicornis (Greville) Schrader and Fenner (in press, b) (Plate 24, Figures 11, 18)

Synonym: Hemiaulus n. sp.(?) in Schmidt et al., pl. 143, fig. $45,46$.

Description: Valve rectangular to slightly elliptical with straight, long horns and a central, conical projection with an open hole (pseudonodulus?) on its top. The valve surface, mantle and central projection are finely punctate, 8-12 punctae in $10 \mu$, which are irregularly and densely distributed. A hyaline ring ( $4 \mu$ wide) just above the margin is free of punctae. On the long horns the punctae form one straight line and are of greater size, 8-9 in 10 $\mu$. At the top of these horns is a broad long spine at the inner side and a smaller spine at the outside. Observed valve diameter at the base, $45-80 \mu$. Observed valve height, $40-130 \mu$.

Stratigraphic Range: This species was described by Greville (1865) from Barbados and was found in this study in the middle Eocene sediments of Site 356 . 
Riedelia pacifica (Jousé in Jousé and Sheshukova-Poretzkaya, 1971) (No illustration)

Description: Jousé and Sheshukova-Poretzkaya (1971), p. 22, pl. 2, fig. 3, 4; Gleser and Jousé in Jousé et al. (1974), p. 60, pl. 3, fig. 11 .

Stratigraphic Record: This species was reported from late Eocene to early Oligocene sediments (Gleser and Jousé, 1974; Jousé and Sheshukova-Poretzkaya, 1971). It was observed in this study in the upper middle Eocene sediments of Site 356.

Riedelia sublevata n. sp.

(Plate 26, Figures 3-5, 15)

Synonym: Hemiaulus alatus Grev. sensu A. Schmidt (1888) ex parte Schmidt et al. (1874-), pl. 143, fig. 16-19, not fig. 15, 20-22.

Description: Valve elliptical. The upper parts of the long horns are bent inward, so that they meet in the middle. The broader the valve the earlier the projections are bent towards the meeting point. In the broadest valves observed, the flexion lies already half way between the base and the apical ends of the horns. The horns become narrower toward their end, $5-7 \mu$ width at their base, $2.5-3 \mu$ width at their apical end. At the inner side of the apical ends of these horns is a long spine (compare Plate 26, Figure 15), but which is lost already in most observed specimens. There is a central conical projection which is also areolated and has a large open hole at its top. The areolae on the horns and the mantle are more or less regularly arranged in straight lines, somewhat radiating at the mantle near the central part. The number of areolae is $10-12$ in $10 \mu$. Between the areolae an irregular network of ribs can be observed. The basal part of the valve just above the margin is free of areolae. A broad hyaline keel runs from the central conical projection towards the apex of the horns, becoming narrower upward from the point of flexion of the horns. Observed valve diameter, $15-46 \mu$. Observed valve height, $40-57 \mu$.

Discussion: Although a long, distinct, single spine at the inner end of each horn was observed, this species was included into the genus Riedelia because of the central conical projection with an open hole (pseudonodule?) on its top, which seems to be typical for this genus, besides its punctate, not polygonal, areolated valve and the absence of pseudoseptae. This species is very closely related to Riedelia alata, the horns of which are also bent inward in their upper part. But $R$. sublevata differs from the latter by its stronger flexion of the horns which resultingly meet in the center, never the case in $R$. alata. From $R$. claviger and $R$. tenuicornis it differs by its coarser areolation and its more robust long horns.

Holotype: Plate 26, Figure 5 from DSDP Leg 39, Sample 356-6-6, 30-31 cm.

Paratype: Plate 26, Figure 15 from DSDP Leg 39, Sample 356-62, $30-31 \mathrm{~cm}$.

Age: Middle Eocene.

Riedelia tenuicornis (Greville) Schrader and Fenner (in press, b) (Plate 25, Figures 2, 9)

Description: Greville (1865a), p. 29, pl. 3, fig. 10; Schmidt et al. (1874-), pl. 143, fig. 9, 10; Grove and Sturt (1887), p. 11, pl. 13, fig. 45 .

Stratigraphic Record: Greville (1865a) and Schmidt (1874-) reported this species from Barbados; Grove and Sturt (1887), from the late Eocene of Oamaru. It is further reported from the late Eocene of the Ukraine (Gleser and Sheshukova-Poretzkaya, 1969). In this study this species was found in the middle Eocene of DSDP Site 356.

Riedelia sp. 1

(Plate 26, Figure 10)

Description: Valve rectangular to slightly elliptical with a central, relatively low, conical projection. The two long horns are straight and are slightly bent inward. The valve, mantle, and horns are sparsely punctate, which is typical for this species, distinguishing it from Riedelia claviger. This species was also found in the late Eocene sediments of the Norwegian Sea (Schrader and Fenner, in press, a, b). Observed valve diameter at the base, $20-29 \mu$; valve height from the base to the apical ends of the lateral projections, 30$37 \mu$.

Riedelia sp.

(Plate 37, Figure 7)
Genus ROUXIA Brun and Heribaud (1893)

Rouxia sp. 1

(Plate 33, Figure 1)

Description: This very long species was only observed in fragments. Valve length, about $125 \mu$; width in the middle part, $6-7 \mu$. Number of striae in $10 \mu, 13-14$. This species was found in the Pliocene of Site 358 (this paper). This species might be identical with Rouxia heteropolara Gombos (in press), which he described from the Pliocene of Site 328.

\section{Genus RUTILARIA Greville (1863a)}

\section{Rutilaria sp. \\ (No illustration)}

Remarks: Only broken specimens of this species were found in the middle Eocene of Site 356 so that no exact determination was possible.

\section{Rutilaria? sp. \\ (Text Figure 7)}

Description: Valve linear in outline with a ventricose, inflated central part and broadly rounded apices. Valve length, $85-100 \mu$; width at the central part, $6-8 \mu$; width at the parallel-sided, narrow, elongated parts, $2.5-3 \mu$. The valve face is finely areolated, $11-15$ areolae in $10 \mu$. The areolae are densely but irregularly distributed, leaving free an irregularly shaped central area, in the center of which is one large process. The process might be the broken off remains of the central linking organ, the periplekton (Ross, personal communication), and therefore was tentatively placed into the genus Rutilaria. At the apices is a small ocellus. In the middle of the valve a hyaline keel-like rib runs from apex to apex, bifurcating at the central part, and by this surrounding it. This species was found extremely rarely in the middle Eocene of Site 356.

\section{Genus RUTILARIOPSIS Van Heurck (1894)}

See discussion under genus Cymatosira.

\section{Rutilariopsis ventricosa (Brun) n. comb.}

(Plate 32, Figures 30, 31)

Goniothecium prolungatum Grev. var. ventricosa Brun (1896), p. 238 , pl. 20, fig. 9-11.

Description: Valve elliptical with elongated apical ends. These elongated ends have also a slightly oval form and terminate in a small process. Valve length, $35-42 \mu$; width at the middle, $8-9 \mu$. The type of areolation is quite variable: in general it is sparsely and irregularly finely areolated. There is always a ring of marginal spines and the characteristic four large subcentral processes in rectangular arrangement.

Discussion: This species was transferred from the genus Goniothecium to the genus Rutilariopsis because of the marginal circle of spines and the strong spines? in the central part.

Age: Middle Eocene.

\section{Rutilariopsis sp. 1}

(Plate 32, Figure 16)

Description: Valve lanceolate with a marginal circle of spines and an oval ring of knots in the central part. An areolation was not observed. The apical ends of the valve terminate into a small elevation. Valve diameter in the middle, $5 \mu$; length, $21 \mu$. This species was observed in the middle Eocene of Site 356.

\section{Rutilariopsis sp. \\ (Plate 32, Figure 6)}

Rutilariopsis sp.

(Plate 32, Figure 15)

Rutilariopsis? sp.

(Plate 32, Figure 19)

Description: Valve rectangular to quadrangular in outline with narrow, attenuating apices, which end in a small elevation. Valve finely, but irregularly areolated with characteristic four strong knots 


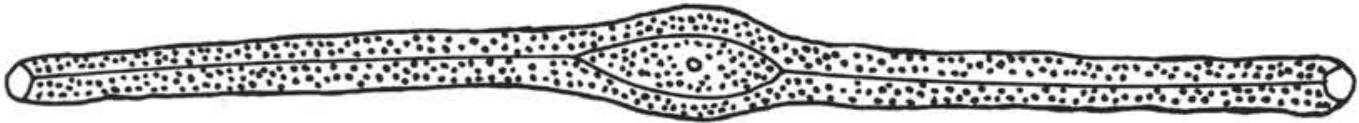

Figure 7. Rutilaria? sp., 1500X, Sample 356-7-6, 30-31 cm.

in the central part, arranged in trapezoid arrangement. Valve length, $21 \mu$; width at the middle, $11 \mu$. This species was observed in the middle Eocene of Site 356.

\section{Genus RYLANDSIA Greville and Ralfs in Greville (1861d)}

\section{Rylandsia biradiata Greville (1861d)}

(Plate 16, Figure 4)

Description: Greville (1861d), p. 68 , pl. 8, fig. 1; Schmidt et al. (1874-), pl. 137, fig. 23-25; Van Heurck (1896), p. 505.

Stratigraphic Record: Middle Eocene of DSDP Site 356 (this study), late Eocene of Oamaru (Greville, 1861d; Schmidt, 1874-). Robinson (1937) reported this species from the Paleogene of Barbados.

\section{Rylandsia sp.}

(Plate 16, Figure 3)

Age: Early Oligocene.

Genus SCEPTRONEIS Ehrenberg (1844)

\section{Sceptroneis ligulatus $\mathrm{n} . \mathbf{s p}$.}

(Plate 31, Figures 8-10)

Description: Valve narrowly lanceolate with a broad clavate headpole and a not broadened truncate footpole. Valve length, 90$160 \mu$; width in the middle, $7-8 \mu$. The valve face is finely striate: $9-11$ striae in $10 \mu$. A hyaline central axis narrows towards the apices and separates the straight facing striae at both sides. The striae are finely areolate. The inner half of the broadened headpole is striated and areolated in the same way as the rest of the valve face. Its outer half is hyaline and surrounded by a ring of areolae and has an eccentrically positioned larger pore (labiate process?) at its base. Further valves were found which had a well-preserved margin, but showed no structure. These hyaline valves were also listed as $S$. ligulatus.

Discussion: No similar species was found in the literature except one broken, badly preserved late Eocene specimen, illustrated as Genus and Species indet. by Gombos (in press, pl. 12, fig. 8), which might belong to the species described here. The described species was included into the genus Sceptroneis because of its heteropolarity within one valve and its arrangement of structure.

Holotype: Plate 31, Figure 10 from DSDP Leg 39, Sample 356-6$6,30-31 \mathrm{~cm}$.

Paratypes: Plate 31, Figure 9 from DSDP Leg 39, Sample 356-75, 30-31 cm; Plate 31, Figure 8 from DSDP Leg 39, Sample 356-6-2, $30-31 \mathrm{~cm}$.

Age: Middle Eocene.

Sceptroneis mayenica Fenner in Schrader and Fenner (in press, b) (No illustration)

Description: Fenner in Schrader and Fenner (in press, b), pl. 22, fig. $22-25$; pl. 23 , fig. $1-4$; pl. 25 , fig. 6,8 .

Stratigraphic Record: Late Eocene of the Norwegian Sea (Schrader and Fenner, in press, a), and middle Eocene of Site 356 (this paper).

\section{Sceptroneis pesplanus Fenner and Schrader in Schrader and Fenner (in press, b)}

(Plate 26, Figure 16; Plate 27, Figure 16)

Description: Schrader and Fenner (in press, b), pl. 22, fig. 30,$31 ;$ pl. 25 , fig. 10,11 .

Stratigraphic Record: Middle Eocene of Site 356 (this paper), middle Eocene-late Eocene of the Norwegian Sea (Schrader and Fenner, in press, a, b).

\section{Sceptroneis tenue Schrader and Fenner (in press, b)} (Plate 32, Figure 8)

Description: Valve narrow, slender, slightly widened in the middle, and with one subcapitate and one truncate-to-broadly rounded apical end. Valve length, $85-138 \mu$; width in the middle, 2 $3.5 \mu$. The number of transapical ribs of these middle Eocene specimens was $6.5-12$ in $10 \mu$, thus being much finer than the late Oligocene specimens from the Norwegian Sea (Schrader and Fenner, in press, a, b).

Stratigraphic Record: Middle Eocene-early Oligocene (this paper); late Eocene-late Oligocene of the Norwegian Sea (Schrader and Fenner, in press, a, b).

\section{Sceptroneis sp. 1 \\ (Plate 29, Figure 4)}

\section{Genus SCHIMPERIELLA Karsten (1905)}

\section{Schimperiella antarctica Karsten (1905)} (Plate 11, Figure 5)

Description: Hendey (1937), p. 256; Fenner (1976), p.779, pl. 14, fig. $1-5$.

Stratigraphic Record: Base of Rhizosolenia curvirostris var. inermis zone to Recent (Donahue, 1970, p. 191; but as Micropodiscus oliveranus), Pleistocene to Recent (Abbott, 1972). In this study it was found in the Pleistocene of Site 358 (Sample 358-1-3, 30$31 \mathrm{~cm}$, upward).

\section{Genus SKELETTONEMA Greville (1865)}

\section{Skelettonema stylifera Brun (1891)}

(Plate 14, Figure 8)

Synonym: Zygoceros antiquus Pantocsek, Vol. II, pl. 25, fig. 377; Vol. III, fig. 391.

Description: Brun (1891), p. 44, pl. 21, fig. 7; Schmidt et al. (1874-), pl. 180, fig. 46. Valve cylindrical with a conical top, at the base of which a ring of $2-5$ broadly based short spines is situated which distinguishes this species from Pseudopyxilla dubia. Besides the ring of spines the valve is structureless. The valve diameter varies from $6-13 \mu$. This species was quite common in the Eocene sediments of Site 356.

Age: Middle Eocene.

Genus STEPHANOGONIA Ehrenberg (1844)

Remarks: This genus is ill defined and the species included in it are only associated to it with hesitation.

\section{Stephanogonia horridus Schrader and Fenner (in press, b)} (Plate 13, Figures 7-9) 6-8.

Description: Schrader and Fenner (in press, b), pl. 12, fig. 4,

Stratigraphic Record: Late Miocene of the Norwegian Sea (Schrader and Fenner, in press, a, b) and middle Eocene of Site 356 (this paper).

\section{Stephanogonia reticulata Forti $(1913$}

(Plate 15, Figures 6, 10)

Description: Forti (1913), p. 1562-1563 (28-29), pl. 3, fig. 8.

Remarks: Two aberrant specimens (Plate 15, Figure 10) were found together with the species in the middle Eocene sediments of Site 356. Forti (1913) reported this species from the Miocene Marmorito Formation.

Stephanogonia striolata Pantocsek (1889) (Plate 34, Figure 34)

Description: Pantocsek (1889), p. 76, pl. 18, fig. 292.

Remarks: This species was described by Pantocsek (1889) from the Miocene of Szakal, Hungary. It was found in the middle Eocene of Site 356 (this study). 
Genus STEPHANOPYXIS Ehrenberg (1844)

Stephanopyxis barbadensis (Greville) Grunow (1884) (No illustration) fig. 14 .

Description: Grunow (1884), p. 91; Hanna (1927), p. 120, pl. 20,

Stratigraphic Record: Middle Eocene (this study), late Eocenelate Oligocene of the Norwegian Sea (Schrader and Fenner, in press, a, b); early Miocene of California (Hanna, 1927).

Stephanopyxis corona (Ehrenberg) Grunow in Van Heurck Syn. (18801885)

(Plate 12, Figure 12)

Description: Grunow (1884), p. 90; Van Heurck (1880-1885), pl. $83 \mathrm{C}$, fig. 10, 11; Schmidt et al. (1874-), pl. 123, fig. 10-17; pl. 130, fig. 16, 17, 36; Van Heurck (1896), pl. 434, fig. 138; Hanna and Grant (1926), p. 166, pl. 20, fig. 11.

Stratigraphic Record: Miocene (Schmidt et al., 1874-; Hanna and Grant, 1926); middle Eocene in this study.

\section{Stephanopyxis grossecellulata Pantocsek (1886)} (No illustration)

Description: Pantocsek (1886), pl. 20, fig. 180.

Stratigraphic Record: Middle Eocene (this paper), late Oligocene of the Norwegian Sea (Schrader and Fenner, in press, a, b), Miocene at Szent Peter, Hungary (Pantocsek, 1886). It was further reported by Laporte and Lefébure (1929) from Monte foss. Casatico in Italy.

Stephanopyxis grunowii Grove and Sturt in A. Schmidt Atlas (1888) (Plate 12, Figures 10, 13)

Description: Schmidt et al. (1888), pl. 130, fig. 1-5.

Stratigraphic Record: Cretaceous-Miocene. Cretaceous of Moreno (Hanna, 1927). Late Eocene of Oamaru (Schmidt et al., 1888. Late Oligocene of Site 338, Norwegian Sea (Schrader and Fenner, in press, a, b). Monterey Miocene (Hanna; Schultze and Kain, 1896); DSDP Hole 328B (Gombos, in press, DSDP Leg 36). In this study it was found in the middle Eocene sediments of Site 356.

Remarks: Further study is necessary to clear whether Stephanopyxis schenkii Kanaya (1959) is a valid new species or has to be treated as a synonym to Stephanopyxis grunowii.

\section{Stephanopyxis inordinata Hajós (1976) (Plate 6, Figures 3, 4)}

Description: Hajós (1976), p. 825, pl. 20, fig. 4, 5 .

Stratigraphic Range: Early Oligocene of the southwestern Pacific (Hajós, 1976); middle Eocene (this paper).

\section{Stephanopyxis marginata Grunow (1884)}

(Plate 12, Figure 11)

Description: Grunow (1884), p. 90, pl. 5, fig. 17.

Remarks: This species was described by Grunow from his Franz Josef Land samples. It was found in the late Oligocene sediments of Site 338 of the Norwegian Sea (Schrader and Fenner, in press a, b) and occurs in the middle Eocene sediments of Site 356 (this study).

\section{Stephanopyxis punctatus Jousé (1955)}

(Plate 12, Figure 2)

Illustration: Sheshukova-Poretzkaya (1967), pl. 13, fig. 1.

Stratigraphic Range: Eocene-Oligocene. Middle Eocene of west Siberia and late Eocene of the east slope of the Urals and west Siberia (Strelnikova, 1960); Paleocene of the European USSR (Gleser, 1962) and west Siberia and north Kazakstan (Jousé, 1955); middle Eocene of DSDP Site 356 (this study).

\section{Stephanopyxis reticulata Long, Fuge and Smith (1946)}

(Plate 37, Figures 10, 11)

Description: Long, Fuge and Smith (1946), p. 111, pl. 19, fig. 8; Strelnikova (1974), p. 57, pl. 5, fig. 7-13.

Stratigraphic Record: Late Cretaceous of the Moreno Shale, California (Long et al., 1946) and Late Cretaceous of east Russia (Strelnikova, 1974). In this study this species was found in the middle Eocene sediments of Site 356 as well as in the early Oligocene sediments of Site 354 .
Stephanopyxis superba (Greville) Grunow (1884)

(Plate 12, Figure 1)

Description: Grunow (1884), p. 91. Greville (1865), p. 68, pl. 8, fig. 3-5. Schmidt et al. (1874-), pl. 123, fig. 3-8.

Stratigraphic Record: Eocene-early Miocene. Barbados (Greville, 1865; Grunow, 1884); Springfield (Schmidt et al., 1874-, pl. 123); late Eocene-early Miocene in DSDP Hole 328B (Gombos, in press, DSDP Leg 36); late Eocene of the southwestern Pacific sediments (Hajós, 1976); middle Eocene of Site 356 in this study.

Stephanopyxis turris (Greville and Arnott) Ralfs in Pritchard (1861) (Plate 12, Figure 7) p. 87 .

Description: Hustedt (1930), p. 304, fig. 140. Grunow (1884),

Stratigraphic Record: From Upper Cretaceous (Strelnikova, 1974 , p. 22-23) to Recent. Not diagnostic. Reported by Koizumi (1973) of the Miocene and Pliocene of the north Pacific; by Schrader (1974) from the Cenozoic of the tropical Indian Ocean. This species is very common in the Paleogene of the USSR (Wolgadistrict, Ural, west Siberia); of Jutland (Moler); South Sweden and the Norwegian Sea (Schrader and Fenner, in press, a, b). Presently Stephanopyxis turris seems to be confined to the tropical and subtropical neritic regions (Jousé, 1974).

\section{Stephanopyxis turris (Greville and Arnott) Ralfs in Pritchard var.} (Plate 12, Figures 8, 9)

Remarks: The specimens illustrated under this name were found in the Eocene sediments of Site 356. They are identical with the specimens illustrated in Schmidt et al. (1874-), pl. 130, fig. 43 as Stephanopyxis turris var. similar to var. subconstricta Grunow.

\section{Genus STICTODISCUS Greville (1861a)}

Stictodiscus sp.

(Plate 1, Figures 4, 5)

Description: Valve circular, convex with a highly elevated central part. The areolae are arranged in radial rows increasing in size toward the margin, 5-10 areolae in $10 \mu$ near the center, and 4-6 near the margin. The last marginal areola of each row is elongated. Between the rows are irregularly distributed interstitial meshes. In the center is one large areola? (process?). Valve diameter, 25-33 $\mu$. Margin width, $1 \mu$. This middle Eocene diatom is closely related to Stictodiscus californicus Greville (1861) because of its large areolae, arranged in radial rows. But it differs from the latter by its elevated central part and the interstitial meshes. In Schmidt et al. (1874-), pl. 444, fig. 1, 2 are Miocene specimens of Stictodiscus californicus illustrated, which also show interstitial meshes. But these specimens still differ from the here described by the non-elevated central area, their conspicuously broad margin and equal-sized areolae.

\section{Stictodiscus californicus var. nitida Grove and Sturt (1887)} (Plate 1, Figure 14; Plate 3, Figure 5)

Synonym: Stictodiscus nitidus Grove and Sturt (1888).

Description: Grove and Sturt (1886-1887), p. 66, pl. 5, fig. 7 .

Stratigraphic Record: Late Eocene-Oligocene of the southwestern Pacific, Hajós (1976); Grove and Sturt (1887) and Schmidt et al. (1874-), pl. 451, fig. 7, reported it from Oamaru (late Eocene); Gombos (DSDP Leg 36, in press), late Eocene-late Oligocene of the southern Atlantic. In this study it was observed in the middle Eocene sediments of Site 356.

\section{Stictodiscus parallelus (Ehrenb.) Grove and Sturt (Appendix, 1887) (Plate 28, Figure 6)}

Description: Schmidt et al. (1874-), pl. 75, fig. 13; pl. 76, fig. 1417; Greville (1865d), p. 104, pl. 9, fig. 22, 23; Grove and Sturt (Appendix, 1887), p. 138, pl. 14, fig. 28.

Remarks: Only triangular specimens were found.

Stratigraphic Record: Late Eocene of Oamaru (Grove and Sturt, 1887), middle Eocene of Site 356 (this study). The specimens illustrated in Schmidt et al. (1874-) come from sediment of Camp. Bay, which are of Recent age after Hendey (1972). 


\section{Stictodiscus sp. 1}

Remarks: Only one single specimen was found. It seems to be closely related to the Eocene Stictodiscus grovei A. Schmidt (Schmidt et al., 1874-, pl. 147, fig. 5,7 ) but differs from the latter in its large elongated areolae in the center, forming a triplet. This species was found in the middle Eocene sediments of DSDP Site 356.

\section{Genus SYNEDRA Ehrenberg (1830)}

\section{Synedra miocenica Schrader (1976)}

(Plate 33, Figure 23)

Description: Schrader (1976), p. 94, pl. 1, fig. 1.

Remarks: Also relatively short specimens $(48 \mu \mathrm{m}$ length) were found but being identical with the species in their number of marginal transapical striae.

Stratigraphic Record: Middle Oligocene-early Miocene of the Norwegian Sea (Schrader and Fenner, in press, a, b); middle Miocene of the South Pacific Ocean (Schrader, 1976); and early Oligocene-Pleistocene (this paper).

\section{Synedra sp. \\ (No illustration)}

Remarks: This middle Eocene species resembles the shorter forms of Synedra miocenica, but differs from the latter by its larger marginal transapical striae.

\section{Genus THALASSIONEMA Grunow (1881)}

Thalassionema hirosakiensis (Kanaya) Schrader (1973) (Plate 20, Figure 7)

Description: Kanaya (1959), p. 104-106, p. 9, fig. 11-15 (as Fragilaria hirosakiensis).

Remarks: For discussion see Thalassionema robusta Schrader.

Stratigraphic Range: Miocene of northeast Japan (Kanaya, 1959); early-middle Miocene of the Norwegian Sea (Schrader and Fenner, in press, a, b); Pliocene-early Pleistocene of the northeast Pacific (Schrader, 1973), Miocene of Hungary (Hajós, 1973); late Pliocene (this study).

Thalassionema nitzschioides Grunow in Van Heurck var. parva Heiden in Heiden and Kolbe (1928)

(Plate 19, Figure 10; Plate 20, Figure 8; Plate 33, Figure 5)

Description: Heiden and Kolbe (1928), p. 564, fig. 118.

Stratigraphic Record: Early Miocene of the tropical Pacific Ocean (Jousé, 1973) to Recent (Heiden and Kolbe, 1928; Fenner et al., 1976).

\section{Thalassionema robusta Sehrader (1973)}

(Plate 33, Figures 21, 22)

Description: Schrader (1973), p. 712, pl. 23, fi . 24, 35-37.

Remarks: The number of marginal punctae is $9-11$ in $10 \mu$, in this characteristic being intermediate between Thalassionema robusta and Thalassionema hirosakiensis. The valve shape of Thalassionema hirosakiensis is described to be highly variable from narrow lanceolate, to linear, to elongate-quadrate, but mostly weakly capitated. In the here investigated samples the variability reached from linear forms with nearly parallel margins, which were capitate, to lanceolate forms, which were slightly or not capitate. In this study the distinctly capitate forms were listed as Thalassionemo hirosakiensis and the noncapitate lanceolate forms as Thalassioneme robusta. But further study is necessary to clear the taxonomic relation between these two species.

Stratigraphic Range: Middle Miocene-Pliocene of the northeast Pacific (Schrader, 1973); Pliocene (this study).

\section{Genus THALASSIOSIRA Cleve (1873)}

\section{Thalassiosira eccentrica (group) (Ehr.) Cleve (1904)} (No illustration)

Description: Sheshukova-Poretzkaya (1967), p. 141-142, pl. 14, fig. 4. Fryxell and Hasle (1972), p. 302 ff. numerous figures.
Simonsen (1974), p. 9, pl. 2, fig. 1-3. Hustedt (1930), p. 388 , fig. 201 (as Coscinodiscus excentricus).

Thalassiosira eccentrica (Ehr.) Cleve var. leasareolatus Kanaya in Kanaya and Koizumi (1966)

(Plate 5, Figure 1)

Synonym: Thalassiosira pacifica Gran and Angst, Jousé (1962). Description: Kanaya and Koizumi (1966), p. 125, Koizumi (1973), p. 832 , pl. 3 , fig. 7-11.

\section{Thalassiosira lineata Jousé (1968)}

(No illustration)

Description: Jousé (1968), p. 13, pl. 1, fig. 1, 2.

Thalassiosira oestrupii (Ostenfeld) Proschkina-Lavrenko (1956) (No illustration)

Description: Hustedt (1930), p. 318, fig. 155 (as Coscinosira oestrupii).

Thalassiosira? sp. 1

(Plate 3, Figures 7, 8)

Description: Valves circular, flat with a slight concentric undulation. The areolae are increasing in size from the center, 16-20 areolae in $10 \mu$, toward the margin. The areolae are arranged in radial rows. The rows are not always straight, but slightly curved. In the center of the valve is a cluster of pores, surrounded by a hyaline ring. This species was found in the middle Eocene sediments of Site 356 and the early Oligocene sediments of Site 354 .

Discussion: As no complete specimen could be found an exact taxonomic adjoinment was not possible. This species is very similar to some specimens I found in late Eocene-late Oligocene sediments of the Norwegian Sea (Schrader and Fenner, in press, a, p. 33, fig. 6). A species similar to the here described is Coscinodiscus capensis Grunow (1884), which was described by him from the brackish water of the Baakens River (Capland, South Africa), and which has a distinct circle or even double-circle of marginal spines. There is also some resemblance to Coscinodiscus intumescens Pantocsek (1906, pl. 2, fig. 17) from the marine Tertiary of Felsö-Esztergály (Hungary), and to Thalassiosira aff. irregulata Schrader and Fenner (in press, a, b) found in the late Oligocene of the Norwegian Sea.

Thalassiosira sp.

(Plate 9, Figure 4)

Genus THALASSIOTHRIX Cleve and Grunow (1880)

Thalassiothrix longissima Cleve and Grunow (1880) (Plate 33, Figures 15-20)

Description: Hustedt (1959), p. 247, fig. 726. Hasle and Mendiola (1967), p. 114, fig. 20, 35-37, 45, 46, 53. Schrader (1976), p. 98, pl. 1, fig. 5, 6, 15-17.

Remarks: The specimens observed were highly variable. In the late Miocene-early Pleistocene sediment samples from DSDP Site 358 very large specimens (Plate 33, Figures 15-17) dominated besides the thinner specimens occurring from Oligocene to Recent. The diameter of the larger specimens varies from $5-7 \mu$. These specimens have a coarse marginal transapical striation, $10-12$ striae in $10 \mu$. These striae consist of fine punctae still recognizable at a magnification of $1000 \times$. At the swallow-tailed end the striae converge to the middle of the valve in some distance from the valve end. In the hyaline part between the converged striae and the end of the valve one large pore is positioned. Such large specimens were also observed by Schrader (1976).

Stratigraphic Record: Oligocene-Recent in the Norwegian Sea (Schrader and Fenner, in press); middle Miocene of Trinidad (Lohman, 1974); Miocene of northeast Japan (Kanaya, 1959); Miocene-Recent in the tropical Indian Ocean (Schrader, 1974); and the southeastern Pacific Ocean (Schrader, 1976); early OligocenePleistocene (this paper).

\section{Genus TRICERATIUM Ehrenberg (1841)}

\section{Triceratium acutangulum Strelnikova (1974)} (Plate 31, Figure 1)

Description: Strelnikova (1974), p. 83, pl. 32, fig. 1-10. 
Stratigraphic Record: Late Cretaceous of west Siberia (Strelnikova, 1974); late Eocene-middle Oligocene of the Norwegian Sea (Schrader and Fenner, in press, a, b). Greville (1864) reported 4angled specimens from Barbados. In this study it was found in the middle Eocene of DSDP Site 356.

\section{Triceratium americanum Ralfs in Pritchard (1861) (No illustration)}

Description: Schmidt et al. (1874-), p. 76 , fig. 28 ; pl. 159, fig. 5; Hanna (1927), p. 122, pl. 21, fig. 3.

Stratigraphic Record: Middle Eocene-middle Miocene. In this study it was found in the middle Eocene of Site 356. Further records come from: late Eocene of Oamaru (Schmidt et al., 1874-); early Miocene of Phoenix Canyon near Coalinga, California (Hanna, 1927); middle Miocene of Richmond, Virginia and Nottingham, Maryland (Schmidt et al., 1874-; and Hanna, 1927).

\section{Triceratium barbadense Greville (1861a)} (Plate 30, Figures 12-14)

Description: Greville (1861a), p. 44, pl. 4, fig. 12; Kanaya (1957), p. 100-101, pl. 7, fig. 1-4.

Remarks: The description and differential diagnoses of Kanaya (1957) was followed. But further investigations on the occurrence and variability of this species and Trinacria deciusi Hanna (1927) and Triceratium inconspicuum var. trilobata are necessary to exactly define this group of small Paleogene Triceratia.

Stratigraphic Record: Late Eocene of the Tuamoto Islands (Jousé, 1968); Barbados (Greville, 1861; Schmidt et al., 1874-); late Eocene of Oamaru (Grove and Sturt, 1889); Eocene of California, Kellogg and Sidney Shales (Kanaya, 1957); Eocene of the equatorial Atlantic, late Eocene of the Ukraine (Alminski-Stage), and of west Kasakhstan; late Eocene of the Pacific (Gleser and Jousé, 1974); late Eocene of the Norwegian Sea (Schrader and Fenner, in press, a, b); and middle Eocene of DSDP Site 356 (this study).

\section{Triceratium brachiatum Brightwell (1856)} (Plate 30, Figures 27-31)

Synonym: Trinacria deciusi Hanna ex parte Hanna (1927), p. 36, pl. 5, fig. 5, not fig. 3 .

Description: Brightwell (1856), p. 274, pl. 17, fig. 3, Schmidt et al. (1874-), pl. 77 , fig. 22-24.

Remarks: Besides the typical form with the elongated, bluntly truncated apices and the segmentation by pseudoseptae which separate a wide elevated hexagonal central area with sides almost equal in length from the angles, there is always one single spine in the central part eccentrically lain close to the middle of one of the pseudoseptae (see Plate 30, Figure 31). In the rectangular, elongated angles the areolae are sparse, but a horseshoe-like elevated siliceous ring is visible. The size of areolae is quite variable, 7-12 areolae in $10 \mu$.

Stratigraphic Record: Cretaceous of California, Hanna (1927). This species was described from Barbados (Brightwell, 1856; Schmidt et al., 1874-) and found in the middle Eocene of Site 356 (in this study).

\section{Triceratium castelliferum Grunow in Schmidt et al. (1874-)} (Plate 29, Figure 9)

Description: Schmidt et al. (1874-), pl. 128, fig. 17, 18; pl. 152, fig. 18. Brun (1893-1896), Vol. II, pl. 21, fig. 17.

Stratigraphic Record: Late Eocene of Oamaru (Schmidt et al., 1874-). In this study it was found in the middle Eocene of Site 356.

\section{Triceratium condecorum Brightwell (1853)}

(Plate 28, Figure 7; Plate 29, Figure 1)

Description: Brightwell in Q.I.M.S. (1853), p. 250, pl. 4, fig. 12; Schmidt et al. (1874-), pl. 76, fig. 27; Hanna (1932), p. 221, pl. 17, fig. 1,3 .

Stratigraphic Record: Late Eocene of Oamaru (Schmidt et al., 1874-; Grove and Sturt, 1889), late Eocene to early Oligocene (Gleser and Sheshukova-Poretzkaya, 1962, 1965, 1969; Gleser et al., 1965). This species is particularly common during the Miocene: Miocene of "Nottingham Maryland," (Brightwell, 1853; Schmidt et al.,1874-); Miocene of Sharktooth Hill (Hanna, 1932); middle Miocene of the east coast of North America (Boyer, 1904); Miocene of Maryland
(Cavallero, 1974); Miocene of Hungary: Szakal and Szent-Peter (Pantocsek, 1903-1905); upper Miocene of Szurdokpüspöki (Cheneviére, 1934); Miocene of Japan (Ichikawa, 1960; Kanaya, 1959) and middle-late Miocene of the northeast Pacific (Schrader, 1973). Kanaya and Koizumi (1970) report this species from the early to middle Miocene of the north Pacific. In this study it was found in the middle Eocene of DSDP Site 356 and the early Oligocene of DSDP Site 354.

\section{Triceratium davidsonianum Truan y Luard and Witt (1888)}

(No illustration)

Description: Truan y Luard and Witt (1888), p. 23, pl. 7, fig. 11. Valve with concave sides and broadly conical apices, valve pulvinate. The large elongated areolae, $3-4$ in $10 \mu$, decrease in size slightly towards the margin and are arranged in irregularly radiating lines, somewhat remote, with irregularly distributed small punctae between them. The angles are finely areolated with approximately 10-12 areolae in $10 \mu$. Observed distance between the angles, 23-40 $\mu$. This species differs from Triceratium inelegans Greville by its small punctae irregularly distributed over the valve surface and by its shape.

Stratigraphic Record: This species was described from the Miocene "Polycystinenkreide" from Jérémie in Haiti by Truan y Luard and Witt (1888). I have found this species in the middle Eocene of Site 356.

\section{Triceratium delicatum Greville (1861a)}

(Plate 27, Figure 6)

Description: Greville (1861d), p. 70, pl. 8, fig. 11.

Remarks: Only rare and smaller and finer areolated specimens than Greville (1861) describes from the Barbados deposit were found. Single specimens of this species were found in the middle Eocene of DSDP Site 356 (this study).

\section{Triceratium groningensis Reinhold (1937)} (Plate 28, Figures 1, 2)

Description: Reinhold (1937), p. 126, pl. 20, fig. 9.

Remarks: Observed length from angle to angle, $45-120 \mu$.

Stratigraphic Record: This species was described as common from the middle Miocene Wonosari-Series (Java). In this study it was found commonly in the early Oligocene of Site 354, but it occurred also in the middle Eocene of Site 356.

\section{Triceratium inconspicuum Greville (1861d)} (Plate 30, Figures 21, 22)

Description: Greville (1861d), p. 70, pl. 8, fig. 10.

Stratigraphic Record: Barbados (Greville, 1861); late Eocene of the Norwegian Sea (Schrader and Fenner, in press, a, b); late Eocene of California: Kellogg and Sidney Shales (Kanaya, 1957); late Eocene of the North Donez Basin (Gleser et al., 1965); and middle Eocene of DSDP Site 356 (this study).

Triceratium inconspicuum Greville var. trilobata n. var. (Plate 30, Figures 23-26)

Synonym: Triceratium inconspicuum Grev.? in Schmidt et al. (1874-), pl. 77, fig. 25-28 (not fig. 29).

Description: This variation differs from the species described by Greville from Barbados in having only three truncate to subtruncate apices. The central hexagonal part is separated from the apices by pseudoseptae. This six sides of the central part being equal in length. In the central part the areolae are more or less regularly arranged in circles around the center, where a central larger areola may or may not be present. On the apices the areolae are of the same size as in the central part and are arranged more or less regularly in straight lines. The observed length from the middle of one apex to the neighboring one is $10-20 \mu$. A tendency from finer areolated to coarser areolated specimens was observed between Samples 356-8-2, 30-31 cm, and 3566-2, 30-31 cm.

Discussion: This variation of Triceratium inconspicuum Grev. was included into Triceratium barbadense Greville by Kanaya (1957). But the here described specimens are clearly separated from Triceratium barbadense by their truncate or subtruncate apices.

Holotype: Plate 30, Figure 25 from DSDP Leg 39, Sample 356-7-6, $30-31 \mathrm{~cm}$. 
Paratype: Plate 30, Figure 23 from DSDP Leg 39, Sample 356-6-2, $30-31 \mathrm{~cm}$.

Age: Middle Eocene-late Eocene.

Triceratium indefinitum (Jousé) Strelnikova (1974)

(Plate 29, Figures 5, 7)

Description: Jousé (1951b), p. 50, pl. 2, fig. 5; Strelnikova (1974), p. 82 , pl. 30 , fog. $1-29$.

Stratigraphic Record: Late Cretaceous of west Siberia (Strelnikova, 1974) and middle Eocene of Site 356 (this study).

Remarks: This species is very closely related to Triceratium caudatum Witt (see Schmidt et al., 1874-, pl. 111, fig. 18-23). Studies of the type material are necessary to exactly define and distinguish both from each other.

\section{Triceratium? labyrinthaeum Greville (1861d)}

(No illustration)

Description: Greville (1861d), p. 70, pl. 8, fig. 12.

Stratigraphic Record: Barbados (Greville, 1861d) Van Heurck Synopsis; Schmidt et al., 1874-, pl. 151). This species was found in the middle Eocene of Site 356 (this study).

\section{Triceratium schulzii Jousé (1949)}

(Plate 30, Figures 1-11; Plate 37, Figure 3)

Synonyms: Triceratium inconspicuum Grev.? var.? Schmidt et al. (1874-), pl. 77, fig. 29 (this figure only); Triceratium insipiens Witt sensu Hanna, 1927(a), p. 123, pl. 21, fig. 7; Triceratium sp. Schulz (1935), p. 399; Triceratium sp. a Kanaya (1957), p. 102-103, pl. 7, fig. 5-7.

Description: Kanaya (1957), p. 102-103, pl. 7, fig. 5-7. Strelnikova (1974), p. 81, pl. 29, fig. 1-7.

Remarks: This highly variable species was very common in the middle Eocene sediments of Site 356. The apices-outlines vary from semicircles to quadrates. The apices become extremely broadly rounded or conical with rounded ends in the larger specimens. But all show the characteristic one or two siliceous ribs projecting inward from each apex. In the very broadly angled specimens there are also up to three such ribs. The valve surface is densely covered with punctae, $12-13$ punctae in $10 \mu$. The thickenings on the outside of the valve give the impression of large areolae. There were two types of arrangement of these "areolae" observed in the same samples: (1) The areolae are irregularly and loosely scattered over the valve surface with irregularly distributed smaller areolae between them. (2) The areolae form a circle around a wide areolae-free center or a central large areola with a wide areolae-free ring around it. Outside this ring the areolae are again irregularly distributed. It seems to be probable that this species is heteropolar and that these two types of valves belong together. But no complete frustule was found to prove this hypothesis. The ends of the angles may be sloping or may lie in the same level as the rest of the valve. The mantle is high, characterized by siliceous ribs separating elongated fields of areolae. Only the central part at the base is free of structure, but with two areolae in its middle. Observed length from one angle to the other, 12-38 $\mu$; height of the mantle in the middle part, 9-18 $\mu$.

Stratigraphic Record: Late Cretaceous of west Siberia (Strelnikova, 1974); the Danziger Bucht (Schulz, 1935); Cambridge Estate of Barbados (Schmidt et al., 1874-); Eocene of California, Kellogg and Sidney-Shale (Kanaya, 1957); early Oligocene(?) Refugian Stage of California (Hanna, 1927); middle Eocene of Site 356 (this study).

Triceratium schulzii Jousé var. quadriloba $\mathbf{n}$. var. (Plate 30, Figures 15-20)

Description: This variation differs from the species only by its four angles instead of three. Characteristic are the one or two ribs projecting inward from the end of each apex. As in the species too, two types of areolation were observed in the same samples: one type with a circular areolae-free wide central area and the other type with irregularly distributed areolae over the total valve surface. The angles are separated from the quadratic to octagonal central part of the valve by pseudoseptae. Observed length from one apex to the next, 15-30 $\mu$.

Discussion: Small specimens might be somewhat similar to Triceratium cruciforme, because their angles cover the whole margin of the central part, but they still are distinguished from the latter species by the rib projecting inward from the end of each angle and by the coarser and more loosely and irregular areolation. The same characteristic separates this species from Triceratium tesselatum (Krotov) Strelnikova (1974).

Holotype: Plate 30, Figure 19 from DSDP Leg 39, Sample 356-9-2, 30-31 cm.

Paratypes: Plate 30, Figure 15 from DSDP Leg 39, Sample 356-9$2,30-31 \mathrm{~cm}$. Plate 30, Figure 18 from DSDP Leg 39, Sample 356-8-1, $51-52 \mathrm{~cm}$.

Age: Middle Eocene.

Triceratium seychellense Grunow in Van Heurck (1883) (Plate 28, Figure 8)

Description: Van Heurck (1896), pl. 110, fig. 1; Schmidt et al. (1874-), pl. 81, fig. 15.

Age: Middle Eocene.

\section{Triceratium tesselatum Greville (1861)}

(No illustration)

Description: Greville (1861d), p. 71, pl. 8, fig. 14.

Stratigraphic Record: Miocene of Nottingham, Maryland (Bailey, 1844; Greville, 1861); late Paleocene of Site 327, South Atlantic (Gombos, in press); late Eocene-middle Miocene of the Norwegian Sea (Schrader and Fenner, in press, a, b); middle Eocene of Site 356 and early Oligocene of Site 354 (this study).

Triceratium sp. 1

(Plate 28, Figure 11)

Description: This large species is characterized by the convex sides and the strongly elongated angles with capitate, rounded ends. The top of the horns on the apices bear finer spines. The center of the valve is convex and covered densely with areolae, which are arranged in radial lines. Irregularly distributed between the areolae are small punctae. Observed length between two angles, 50-75 $\mu ; 7-8$ areolae in $10 \mu$.

Discussion: This species is similar to large specimens of Triceratium indefinitum. But it differs from the latter by its elongated narrower angles which are subcapitate to capitate. This species was included into the genus Triceratium because no spines could be seen at the top of the horns.

Age: Middle Eocene.

Triceratium sp.

(Plate 28, Figure 5)

\section{Genus TRINACRIA Heiberg (1863)}

\section{Trinacria excavata Heiberg (1863)}

(No illustration)

Description: Hustedt (1930), p. 887-888, fig. 532.

Remarks: The observed length from one angle to the neighboring one was $45-105 \mu$.

Stratigraphic Record: Late Cretaceous of the southwestern Pacific (Hajós and Stradner, 1975); Late Cretaceous of California (Hanna, 1927); early Eocene of Jutland, Moler Formation (Benda, 1972; Schmidt et al., 1874-); late Eocene-Miocene of the Norwegian Sea (Schrader and Fenner, in press, a, b); late Eocene of the Ukraine (Gleser et al., 1965; Gleser and Sheshukova-Poretzkaya, 1968); late Eocene-late Oligocene of the Southwest Atlantic (Gombos, in press); late Eocene of Barbados (Greville, 1864); late Eocene-early Oligocene of the Southwest Pacific (Hajós, 1976); middle Miocene? of the tropical Indian Ocean (Schrader, 1974); Miocene-early Pliocene of the southwest Pacific (Schrader, 1976); early Oligocene-early Pliocene of the Southern Ocean (McCollum, 1975); middle Eocene of the south Atlantic (DSDP Site 356, this study).

Trinacria excavata Heiberg forma tetragona A. Schmidt (1888) in Schmidt et al. (1874-)

(Plate 27, Figures 9, 10, 11)

Synonym: Solium exsculptum sensu Witt in Schmidt et al. (1874-), pl 152, fig. 24,25 .

Illustration: Schmidt et al. (1874-), pl. 152, fig. 26-28. 
Description: Valve tetragonal with straight to concave sides and a horn at each apex. The areolae are more or less loosely arranged in radial lines, slightly increasing in size towards the margin from 6-9 areolae in $10 \mu$ to 5-7 areolae in $10 \mu$. Between the areolae, irregularly distributed small punctae are present. The areolae leave free a central hyaline space with a central to subcentral spine. Observed side length: $21-50 \mu$.

Stratigraphic Record: A. Schmidt (1888) reported this species from the early Eocene of Mors, Jutland. In this study it was found in the middle Eocene of DSDP Site 356. This species I have also found as being characteristic for the late Eocene of the Norwegian Sea (Schrader and Fenner, in press, a, b).

\section{Trinacria pileolus (Ehrenberg) Grunow (1884)} (Plate 24, Figures 16, 17)

Description: Grunow (1884), p. 68, pl. B, fig. 59, 60; Schmidt et al. (1874-), pl. 97, fig. 11-14; pl. 111, fig. 6, 17; Hustedt (1930), p. 885 , fig. 529 .

Stratigraphic Record: Late Cretaceous of the southwest Pacific (Hajós and Stradner, 1975), Simbirsk (Schmidt et al., 1874-; Grunow, 1884), late Eocene of the Moler Formation (Jutland) and from the Franz Josef-Land samples (Grunow, 1884). In this study it was found in the middle Eocene sediments of Site 356. Gombos (in press) reports this species from the late Paleocene of Site 327A and late Oligocene of Site 328B. In the Norwegian Sea (Schrader and Fenner, in press, a, b) this species was found from late Eocene-middle Oligocene. In the southeast Pacific it occurred from late Oligocene to early Pliocene (Schrader, 1976). Early Oligocene-early Pliocene of the Southern Ocean (McCollum, 1975).

\section{Trinacria aff. pileolus}

(No illustration)

Description: Valve triangular in outline, with slightly concave sides. Valve densely areolated, 4 areolae in $10 \mu$. Areolae irregularly distributed over the valve surface with also irregularly distributed small punctae between them. This species resembles Trinacria pileolus var. jütlandica Grunow from Mors, Jütland (early Eocene). It was separated from the species because of the coarse, irregular areolation and the only very slightly concave sides. Valve length from apex to apex, $70 \mu$.

Age: Middle Eocene.

\section{Trinacrium simulacrum Grove and Sturt (1887)}

(Plate 29, Figure 2; Plate 31, Figure 2)

Synonym: Triceratium kinkeri A. Schmidt in Schmidt et al. (1874-), pl. 112, fig. 21. Trinacria simulacroides Pantocsek (1892), pl. 28 , fig. 417 .

Description: Grove and Sturt (1886-1887), p. 144, pl. 13, fig. 46 Schmidt et al. (1874-), pl. 127, fig. 14.

Stratigraphic Record: Eocene of the Volga district (Göke, 1972); late Eocene of Oamaru (Grove and Sturt, 1887); late Eocene of the southwest Pacific (Hajós, 1976); late Eocene and late Oligocene of the South Atlantic (Gombos, in press); middle Eocene of DSDP Site 356 (this study), and late Paleocene of DSDP Site 327A (Gombos, in press).

\section{Trinacria subcapitata (Greville) Grunow (1884)} (Plate 27, Figures 2, 7, 8)

Description: Greville (1863), p. 234 , pl. 10, fig. 20; Grunow (1884), p. 69.

Stratigraphic Record: Greville described this species from Cambridge Estate, Barbados. It was further reported from the late Eocene of the North Donez-Basin (Gleser et al., 1965), and the late Eocene of the northeastern margin of the Ukrainian Cristalline Massif (Gleser and Sheshukova-Poretzkaya, 1968).

\section{Genus TROCHOSIRA Kitton (1871)}

Trochosira coronata Fenner and Schrader in Schrader and Fenner (in press, b)

(No illustration)

Description: Schrader and Fenner (in press, b), pl. 29, fig. 9-11; pl. 35 , fig. $7-13,20,21$.

Age: Middle Eocene-middle Oligocene.
Trochosira spinosa Kitton (1870-1871) (No illustration)

Description: Kitton (1871), p. 170, pl. 14, fig. 6, 7. Schmidt et al. (1886), pl. 180, fig. 49.

Age: Middle Eocene-Oligocene.

\section{Genus XANTHIOPYXIS Ehrenberg (1844)}

Xanthiopyxis acrolopha Forti (1912)

(Plate 35, Figures 25, 26)

Description: Forti (1912), p. 84; Forti (1913), p. 15-56, pl. 2, fig. 22, 24, 27, 28, 30-37; Hanna (1927), p. 124, pl. 21, fig. 10; Hajós (1976), p. 826 , pl. 11, fig. 6; pl. 17, fig. 12.

Remarks: For "Stratigraphic Record" see Kanaya (1959), p. 121. In this study this species was found in the early Oligocene of Site 354 and in the middle Eocene of Site 356 .

\section{Xanthiopyxis diaphana Forti (1910)}

(Plate 35, Figures 4, 5)

Description: Forti (1913), p. 1554, pl. 2, fig. 13, 19, 26; Sheshukova-Poretzkaya (1967), p. 181, pl. 24, fig. 4, pl. 26, fig. 3 .

Stratigraphic Record: Miocene-Pliocene. For an extensive list see Sheshukova-Poretzkaya (1967). In this study this species was found in the middle Eocene sediments of Site 356 .

\section{Xanthiopyxis globosa Ehrenberg (1844)}

(Plate 37, Figures 1, 2)

Description: Hanna (1932), p. 224, pl. 18, fig. 3.

Stratigraphic Record: Miocene of Italy (Forti, 1913); Miocene of Sharktooth Hill, California (Hanna, 1932). In this study this species was observed in the middle Eocene of Site 356 and the early Oligocene of Site 354 .

\section{Xanthiopyxis hirsuta Hanna and Grant (1926)}

(Plate 35, Figures 7, 8)

Description: Hanna (1926), p. 170, pl. 21, fig. 10.

Xanthiopyxis hystrix Forti (1913)

(Plate 36, Figures 1, 2)

Description: Forti (1913), p. 1553, pl. 2, fig. 7-9.

\section{Xanthiopyxis oblonga Ehrenberg (1844)}

(Plate 35, Figure 9)

Description: Hanna and Grant (1926), p. 170, pl. 21, fig. 11; Hanna (1927), p. 124; Sheshukova-Poretzkaya (1967), p. 180.

Remarks: For "Stratigraphic Record" see Sheshukova-Poretzkaya (1967). In this study this species was found in the middle Eocene sediments of Site 356, and the early Oligocene sediments of Site 354 . It was found in the middle-late Oligocene of the Norwegian Sea (Schrader and Fenner, in press, a, b).

\section{Xanthiopyxis ovalis Lohman (1938)}

(Plate 35, Figures 20-22)

Synonym: Liradiscus rugulosus Forti (1913), p. 1559, pl. 12, fig. 23.

Description: Lohman (1938), p. 91, pl. 20, fig. 2; pl. 22, fig. 12; Lohman (1973), p. 25, pl. 5, fig. 11.

Stratigraphic Record: Miocene and Pliocene of California and Trinidad (Lohman, 1938, 1973), middle-late Oligocene of the Norwegian Sea (Schrader and Fenner, in press, a, b). Hajós (1968) reported this species from Szurdokpuspöki. In this study this species was found in the middle Eocene sediments of Site 356 and the early Oligocene sediments of Site 354 .

\section{Xanthiopyxis structuralis n. sp.} (Plate 24, Figures 1-5)

Description: Valve oval in outline with a marginal ring of coarse punctae, $8-10$ in $10 \mu$. The valve face shows a very characteristic faint striation: a broad undulated band of 5-8 striae in apical direction, which is broken in transapical direction several times, mostly three times: one break directly in the center, the two others symmetrically at both sides. This broad apical band is accompanied at its sides by 
short transapical striae: $18-22$ in $10 \mu$. Valve length, $13-20 \mu$; width in the middle, 7-11 $\mu$.

Discussion: No similar species was found in the literature. The including of this species into the genus Xanthiopyxis, which is made up principally, if not wholly, by resting spores of Chaetoceros, is problematic, but at the moment seemed to be the best solution because of the valve structure.

Holotype: Plate 24, Figure 3 from DSDP Leg 29, Sample 356-8-1, $51-52 \mathrm{~cm}$.

Paratype: Plate 24, Figure 2 from DSDP Leg 39, Sample 356-6-6, $30-31 \mathrm{~cm}$.

Age: Middle Eocene-early Oligocene.

\section{Xanthiopyxis umbonata Greville (1886)}

(Plate 34, Figure 15)

Description: Greville (1886), p. 2, pl. 1, fig. 5; SheshukovaPoretzkaya (1967), p. 182, pl. 36, fig. 5.

Stratigraphic Record: Late Miocene of Monterey, California (Greville, 1886); late Miocene of California (Wornardt, 1967; Hanna, 1928), Neogene of North Sachalin (Sheshukova-Poretzkaya, 1967) and middle Eocene of Site 356 (this study). The observed Eocene specimens are much smaller than those described from Miocene deposits.

\section{Xanthiopyxis sp. A. Wornardt (1967)}

(Plate 34, Figures 13, 14)

Synonyms: Chaetoceros sp. Reinhold (1947), p. 91, pl. 7, fig. 3, 4; Xanthiopyxis globosa sensu: Gleser and Jousé (1974), pl. 2, fig. 16; not Xanthiopyxis globosa Ehr.

Description: Wornardt (1967), p. 73, fig. 154, 154a

Stratigraphic Record: Early-middle Pliocene of California (Wornardt, 1967); middle-late Oligocene of the Norwegian Sea (Schrader and Fenner, in press, a, b); and middle Eocene of Site 356 (this paper). Reinhold (1937) reports this species from the Neogene of Java; Gleser and Jousé (1974) from the late Eocene of the Ukraine and west Kazakstan, and from the Miocene of the southern part of the west Soviet Union.

\section{Xanthiopyxis sp. B Wornardt (1967)}

(Plate 34, Figure 11; Plate 36, Figures 9, 10)

Description: Wornardt (1967), p. 73, fig. 156.

Stratigraphic Record: Early-middle Pliocene of California (Wornardt, 1967). In this study this species was found in the middle Eocene sediments of Site 356 and the early Oligocene sediments of Site 354 .

\section{Xanthiopyxis sp. C Wornardt (1967)}

(Plate 35, Figures 15, 16)

Description: Wornardt (1967), p. 73, fig. 157, 158.

Stratigraphic Record: Early Pliocene of California (Wornardt, 1967). In this study this species was found in the late Miocene sediments of Site 358, but also in the middle Eocene sediments of Site 356 and the early Oligocene sediments of Site 354.

\section{Xanthiopyxis sp. 1 Hajós in Hajós and Stradner (1975)}

$$
\text { (Plate 34, Figure 12) }
$$

Description: Hajós and Stradner (1975), p. 927, pl. 4, fig. 13

Stratigraphic Record: This species was described from the Late Cretaceous of the southwestern Pacific by Hajos and Stradner (1975); was observed in the middle and late Oligocene of the Norwegian Sea (Schrader and Fenner, in press, a, b); and found in this study in the early Oligocene of Site 354 and the middle Eocene of Site 356.

\section{Xanthiopyxis sp. 1}

(Plate 36, Figure 6)

\section{Xanthiopyxis sp. 2}

$$
\text { (Plate 35, Figures 2, 3) }
$$

Description: Valve outline elliptical with parallel margins. Valve face undulated in transapical direction with a central elevation followed in apical direction by a depression and a further elevation. The valve face is scarcely punctated. Valve length, $60 \mu$; width, $20 \mu$. This species was found in the middle Eocene sediments of Site 356.

\section{Xanthiopyxis sp. 3}

(Plate 35, Figures 10-14; Plate 36, Figure 11)

Description: This species is very close to Xanthiopyxis oblonga, but has a slight central depression. Valve face spinose. Spines irregularly scattered. Valve length, 28-71 $\mu$; width in the middle, 15-18 $\mu$. This species was observed in the middle Eocene sediments of Site 356 and early Oligocene of Site 354 (this study).

Xanthiopyxis sp. 4

(Plate 35, Figure 19; Plate 36, Figures 3, 4)

Xanthiopyxis sp. 5

(Plate 36, Figures 5, 6)

Xanthiopyxis sp. (b)

(Plate 37, Figures 13, 14)

Xanthiopyxis sp.

(Plate 35, Figure 17)

\section{ARCHAEMONADACEAE}

Genus and species indet. (d) Schrader and Fenner (in press, b) (Plate 33, Figure 10)

Description: Schrader and Fenner (in press, b), pl. 25, fig. 38.

Stratigraphic Record: Late Eocene of the Norwegian Sea (Schrader and Fenner, in press, a), middle Eocene of Site 356 (this paper).

\section{Genus and species indet. (e) Schrader and Fenner (in press, b)}

$$
\text { (Plate 33, Figure 12) }
$$

Description: Schrader and Fenner (in press, b), pl. 25, fig. 39.

Stratigraphic Record: Late Eocene of the Norwegian Sea (Schrader and Fenner, in press, a), middle Eocene of Site 356 (this paper).

\section{Genus and species indet. (f) Schrader and Fenner (in press, b)} (Plate 33, Figure 11)

Description: Schrader and Fenner (in press, b), pl. 25, fig. 40.

Stratigraphic Record: Late Eocene (Schrader and Fenner, in press, a), middle Eocene of Site 356 (this paper).

\section{Genus and species indet. (1)}

(Plate 33, Figure 9)

\section{DINOPHYCEAE}

\section{Actiniscus pentasterias Ehrenberg (1854)}

(No illustration)

Description: Dumitricá (1973b), p. 822 , pl. 2, fig. 2, 3, 6-10, 14; pl. 3 , fig. 13,14 ; pl. 5 , fig. $6-8$.

Remarks: Dumitricá (1973b) found wholly siliceous, star-like, endo-skeletal elements of this species (motile stages according to Harland et al., 1967) from late Oligocene to Quaternary in the southwestern Pacific sediments. In this study it was found in the late Miocene sediments of DSDP Site 358.

\section{Genus PSEUDOROCELLA}

Pseudorocella barbadensis Deflandre (1938) in Loeblich et al. (1968) (Plate 23, Figures 13-16; Plate 22, Figures 1-3)

Synonyms: Pseudorocella aff. barbadensis Defl. in Gleser and Jousé (1974), pl. 2, fig. 26, 27; Pseudorocella corona Deflandre (1946), p. 337 , fig. 4 .

Description: Loeblich et al. (1968), p. 207.

Remarks: As all transitions between Pseudorocella barbadensis as it is illustrated in Loeblich et al. (1968) and the species listed above as synonyms were observed in the Eocene and Oligocene samples, and as all have the same stratigraphic range: Eocene-Miocene, all were included into the species Pseudorocella barbadensis Defl. Whether Macrora stella (Azpeitia) Hanna has to be included into this species too, is still questionable. The type material has to be studied. Macrora 
stella was described from the Miocene of Sharktooth Hill, and by Azpeitia (1911) from the Miocene of Spain.

Stratigraphic Record: Gleser and Jousé (1974) report an occurrence of this species, the systematic position of which is not clear, from the Eocene of the equatorial Atlantic and from Barbados. It was found in the middle Eocene of DSDP Site 356 and the early Oligocene of DSDP Site 354 (this paper). Deflandre (1946) described this species from the Miocene of Hungary: Dumitricá (1972) reported it from the Miocene of the Mediterranean Sea. In the Norwegian Sea (Schrader and Fenner, in press, a, b) it was found in the early middle Miocene (described as Macrora stella).

\section{ACKNOWLEDGMENTS}

This investigation was supported by the "Deutsche Forschungsgemeinschaft" grant Schr. 17/5. A great help was that I was allowed to use the private library of Dr. Schrader. I thank Dr. Perch-Nielsen, Dr. Schrader and Dr. Supko for critically reviewing the manuscript. Helpful suggestions concerning taxonomic questions came from Dr. Ross (genus: Rutilaria) and Dr. Andrews (genus: Raphoneis). Technical help came from Mrs. Enke, who prepared the slides; geology student Schneider, who assisted in proofreading and in writing the tables; and from Mrs. Riefer and Mrs. Schmidtmann, who did all typing.

\section{REFERENCES}

Abbott, W.H., Jr., 1972. Vertical and lateral patterns of diatomaceous ooze found between Australia and Antarctica: Ph.D. thesis; Geol. Dept., Univ. of South Carolina, $138 \mathrm{p}$.

Agardh, C.A., 1829. Systema Algarum Adumbravit C.A. Agardh: Lundae Literis Berlingianis XXXVII, 312 p.

Andel, van, T.H. and Corliss, J.B., 1967. The intersection between the Mid-Atlantic Ridge and the Vema Fracture Zone in the North Atlantic: J. Mar. Res., v. 25, p. 343351 .

Andrews, G.W., 1972. Systematic position and stratigraphic significance of the marine Miocene diatom Raphidodiscus marylandicus Christian: 2nd Symp. Recent, Fossil Marine Diatoms, London, Beih. z. Nova Hedwigia, Heft 45, p. 231-250.

1975. Taxonomy and stratigraphic occurrence of the marine diatom Genus Rhaphoneis: 3rd Symp. Recent, Fossil Marine Diatoms, Kiel, Beih. z. Nova Hedwigia, Heft 53, p. 193-229.

Anon., 1975. Working party for a standardization of diatom terminology and diagnoses: 3rd Symp. Recent, Fossil Marine Diatoms, Kiel, 1974. Beihft. z. Nova Hedwigia, Heft 53, p. 323-355.

Azpeitia, D.F.M., 1911. La Diatomologia Española en los Comienzos del Siglo XX. Assoc. Esp. Prog. Ciencias, Congreso de Zaragoza, v. 4, Madrid, 320 p.

Baker, C. de, 1954. The circumpolar Continuity of Antarctic Plankton Species: Discovery Reports, v. 27, p. 201-218.

Barash, M.S. and Gromova, T.S., 1969. Paleotemperature analysis of cores by planktonic foraminifera. In Micropaleontology and organogenous sedimentation in the oceans: Moscow Publishing Office Nauka, p. 153-164.

Barker, P. and Dalziel, W.D., in press. Initial Reports of the Deep Sea Drilling Project, Volume 36: Washington (U.S. Government Printing Office).

Barrett, P.J., 1975. Textural characteristics of Cenozoic Preglacial and Glacial Sediments at Site 270, Ross Sea, Antarctica. In: Hayes, Frakes, et al., Initial Reports of the Deep Sea Drilling Project, Vol. 28, p. 757-768.

Belyaeva, N.V., 1969. The distribution of planktonic foraminifera in sediment cores and methods of their study. In: Micropaleontology and Organogenous Sedimentation in the Oceans, Moscow (Publishing Office Nauka), p. 165175 .
Benda, L., 1965. Diatomeen aus dem Eozän Norddeutschlands. Paläont. Zeitschr., v. 39, p. 165-187.

1972. The diatoms of the Moler Formation of Denmark (lower Eocene). A Preliminary Report: Beihft. z. Nova Hedwigia, Heft 39, 1st Symp. Recent Fossil Marine Diatoms. Bremerhaven, September 12-26, 1970, p. 251266.

Berggren, W.A., 1969. Cenozoic chronostratigraphy, planktonic foraminiferal zonation and the radiometric time scale: Nature, v. 224, p. 1072-1075. 1972. A Cenozoic time scale-some implications for regional geology and paleobiography: Lethaia, v. 5, p. 195-215.

Berggren, W.A. and van Couvering, J.A., 1974. The late Neogene biostratigraphy, geochronology and paleoclimatology of the last 15 million years in marine and continental sequences: Paleogeog., Paleoclim., Paleoecol., v. 16, p. 1-216.

Blow, W.H., 1969. Late middle Eocene to Recent planktonic foraminiferal biostratigraphy: Proc. 1st Int. Conf. Plankt. Microfos., v. I, p. 199-422.

Bory, de Saint Vincent, I.B.M., 1822-1831. Collaborator in: "Dictionaire classique d'Histoire Naturelle," 7 vols., Paris, (v. I, p. 79-80) (diatomaceae are scattered throughout the work; see also pl. 51, fig. 1, 2; pl. 54, fig. 1-3).

Boyer, C.S., 1904. Diatomaceae. In Miocene of Maryland. Maryland Geol. Surv., Miocene Volume, p. 487-507.

Brightwell, T., 1853. On the genus Triceratium with descriptions and figures of the species. Quart. J. Microscop. Sci., v. 1 , p. $245-252$.

1856. Further observations on the genus Triceratium with descripition and figures of new species: Quart. J. Microscop. Sci., v. 4, p. 272-276.

1858. Remarks on the Genus "Rhizosolenia" of Ehrenberg: Quart. J. Microscop. Sci., v. VI, p. 93-95.

Briskin, M. and Berggren, W.A., 1974. Pleistocene stratigraphy and quantitative paleooceanography of tropical North Atlantic Core V 17-205. In Saito and Burckle (ed.): Late Neogene epoch boundaries: Micropaleontology Press, Am. Mus. Nat. Hist., New York.

Brown, N.E., 1933. A rachnoidiscus: London (W. Watson and Sons, Ltd.), p. 88.

Brun, J., 1890-1893. Le Diatomiste, v. I: Journal spécial s'occupant exclusivement des Diatomees et de tout ce qui s'y rattache, several papers, 24 plates.

1893-1896. Le Diatomiste, v. 2: Journal spécial s'occupant exclusivement des Diatomées et de tout ce qui s'y rattache, 260 pages, 24 plates.

1891. Diatomées: Mémoires de la Société de Physique et D'histoire Naturelle de Genève, v. 31, Genève.

1882. Notes sur quelques espèces nouvelles de Diatomées: Le Diatomiste, v. 1, p. 173-177.

1896. Diatomées Miocène: Le Diatomiste, v. 2, p. $229-247$

Brun, J. and Tempère, J., 1889. Diatomées Fossiles du Japan. Espèces Marines et Nouvelles des Calcaires Argileux de Sendai et de Yendo. Mém. Soc. Phys. d'Hist. Nat. Genève, v. 30 , p. $1-75$.

Brun, J. and Heribaud, F.J., 1893. Espèces nouvelles: Le Diatomiste, v. 1, p. 173-177.

Bukry, D. and Foster, D.H., 1973. Silicoflagellate and diatom stratigraphy, Leg 16. In Van Andel, T.H., Heath, G.R., et al., 1973, Initial Reports of the Deep Sea Drilling Project, Volume 16: Washington (U.S. Government Printing Office), p. 815-871.

Burckle, L.H., 1972. Late Cenozoic planktonic diatom zones from the eastern Equatorial Pacific: 1st Symp. Recent, Fossil Marine Diatoms. Bremerhaven. Beihefte z. Nova Hedwigia, Heft 39 , p. 217-250. 
Burckle, L.H., in press. Use of diatoms as tracers of the northward flow of Antarctic Bottom Water: Physics.

Burckle, L.H., Abbott, W.H., and Maloney, J., 1973. Sediment transport by Antarctic bottom water in the southeast Indian Ocean: (Abstr.) Ann. Meet. Am. Geophys. Union, p. 336.

Burckle, L.H. and Biskaye, P., 1971. Sediment transport by Antarctic bottom water through the eastern Rio Grande Rise: (Abstr.) Ann. Meet. Geol. Soc. Am., p. 518.

Burckle, L.H., and Stanton, D., 1975. Distribution of displaced Antarctic diatoms in the Argentine Basin: 3rd Symp. Recent and Fossil Marine Diatoms, Kiel, 1974. Beihft. z. Nova Hedwigia, Heft 53, p. 283-293.

Burckle, L.H., Venkatarathnam, K., and Booth, J.D., 1974. Sediment transport by Antarctic bottom water in the western Indian Ocean: (Abstr.) Ann. Meet. Am. Geophys. Union, v. 55 , p. 312.

Burmistrova, I.I., 1969. Quantitative distribution of benthonic foraminifera in Recent sediments of north region of the Indian Ocean. In Micropaleontology and Organogeneous Sedimentation in the Oceans, Moscow (Publishing Office Nauka), p. 176-187.

Calef, G.W. and Grice, G.D., 1967. Influence of the Amazon River outflow on the ecology of the western tropical Atlantic-II. Zooplankton abundance, copepod distribution, with remarks on the fauna of low-salinity areas: J. Marine Res., v. 25, p. 84-91.

Castracane, Conte A.F. degli Antelminelli, 1875. Contribuzione alla florula delle Diatomee del Mediteraneo ossia esame del contenuto dello stomaco di una Salpa pinnata, pescata a Messina: Alti Accademia pontificia dei nuovi lincei, v. 28, p. 377-396.

, 1876. Die Diatomeen in der Kohlenperiode. In Pringsheim, N. (Ed.), Jahrbucher fur wissenschaftliche Botanik, Bd. 10, Leipzig, p. 1-6.

, 1886. Report on the scientific results of the voyage of H.M.S. Challenger during the years 1873-76: Botany, v. 2: London (H.M. Stationery Office), 178 p.

Cavallero, G., 1974. Diatom zonation in Miocene sediments from Maryland: Ph.D. Dissertation, 47 p., New York.

Cheneviére, E., 1934. Note sur le dépot de terre à Diatomées fossiles (Miocene supérieur) récemment de couvert près de Szurdokpüspöki. Bulletin de la Société Francaise de Microscopie, v. 3, facs. 1, p. 33-36, pl. 3-4. Also Földtani Közlony, Köt 53, p. 216-218.

, 1934. Sur un dépot fossile marin Diatomées situé à Kamischev (Russi centrale). Bulletin de la Société Francaise de Microscopie, v. 3, p. 103-107.

Church, C.C., 1931. Foraminifera of the Kreyenhagen Shale. In Mining in California: Calif. Dept. Nat. Res., Div. Mines, v. 27, p. 202-213.

Ciesielski, P.F., 1975. Biostratigraphy and paleoecology of Neogene and Oligocene silicoflagellates from cores recovered during Antarctic Leg 28, DSDP. In Hayes, D.E., Frakes, L.A., et al., Initial Reports of the Deep Sea Drilling Project, Volume 28: Washington (U.S. Government Printing Office), p. 625-692.

Cita, M.B., 1972. The Miocene/Pliocene Boundary, History and Definition. In Saito, T. and Burckle, L.H. (Eds.), Late Neogene Epoch boundaries (24th Int. Geol. Congr. Montreal, 1972, Symp. 109). Am. Mus. Nat. Hist. Micropal. Press, Spec. Publ. 1, p. 1-30.

Cleve, P.T., 1873. Examination of Diatoms found on the surface of the Sea of Java: Bihang Svenska Vetenskap, Akademiens Handlingar, v. 1, p. 1-13, Stockholm. , 1878. Diatoms from the West Indian Archipelago: Bihand till K. Svenska Vet. Akad. Handligar, v. 5, p. 122.
1885. On some fossil marine Diatoms found in the Moravian "Tegel," from Augarten, near Brün: J. Quekett Microscop. Club, 2nd Ser., v. II, London, p. 165-179.

1903-1904. Plankton table for the North Sea. Bull. Couns. Permanent Internat. l'Exploration de la Mer, 19031904 , p. 216.

Cleve, P.T. and Grunow, A., 1879 (1880). Beiträge zur Kenntnis der arctischen Diatomeen. Kongliga Svenska Vetenskaps-Akademiens Handlingar, v. 17, p. 1215, 7 Taf. (Referat, Botanisch. Centralblatt, v. 5, p. 65-69, 1881).

Cleve-Euler, A., 1941. Alttertiäre Diatomeen und Silicoflagellaten im Inneren Schwedens: Palaeontographica, v. 92 , p. $165-209$, Stuttgart.

1951. Die Diatomeen von Schweden und Finnland. Kungl. Svenska Vetenskapsakademiens Handligar. Fjärde Serien, v. 2, S. 1-163, fig. 1-294, 6 Taf. (Teil 1, Centricae, 1951); v. 4, S. 1-158, fig. 292-483 (Teil II Araphideae, Brachiraphideae, 1953), v. 4, S. 1-255, fig. 484-970 (Teil III, Monoraphideae, Biraphideae I, 1953) v. 5, S. 1-232, fig. 971-1306 (Teil IV, Biraphideae II, 1955); v. 3, S. 1-153, fig. 1318-1683, Taf. 7 (Teil V, Schluss, 1952). Stockholm.

Code of Stratigraphic Nomenclature 1961: Am. Assoc. Petrol. Geol. Bull., v. 45.

Conger, Paul S., 1942. Accumulation of diatomaceous deposits: J. Sed. Pet., v. 12, p. 55-66.

Cox, A., 1969. Geomagnetic Reversals: Science, v. 163, p. 237.

Damuth, J.E. and Kumar, N., 1975. Amazon Cone: morphology, sediments, age, and growth pattern: Geol. Soc. Amer. Bull., v. 86 , p. $863-878$.

David, P.M., 1958. The distribution of the Chaetognatha of the Southern Ocean: Discovery Reports, v. 15, p. 1-24.

Deflandre, G., 1946. Phyllodictyocha nov, gen., Silicoflagellidés et formes affines du Miocène de Hongrie. Bull. Soc. Bot. France, v. 93, p. 335.

Donahue, J.G., 1967. Diatoms as indicators of Pleistocene climatic fluctuations in the Pacific sector of the Southern Ocean. In Progress in Oceanography, v. 4, p. 133-140.

1970a. Diatoms as Quaternary biostratigraphic and paleoclimatic indicators in high latitudes of the Pacific Ocean: Ph.D. Dissertation, New York (Columbia Univ.), 230 p.

1970b. Pleistocene diatoms as climatic indicators in North Pacific sediments: Geol. Soc. Am., Memoir 126, p. 121-138.

Donkin, S.A. and Morpeth, M.B., 1858. On a species of Filamenteous Diatom new Britain. Quarterly J. Microscop. Sci., London, v. VI, p. 11-34.

Dumitricá, P., 1972a. Miocene and Quaternary Ebridians from the Mediterranean Sea, Deep Sea Drilling Project, Leg 13. In Ryan, W.B.F., Hsu, K.-J., et al., Initial Reports of the Deep Sea Drilling Project, Volume 13: Washington (U.S. Government Printing Office), p. 902-933.

1972b. Miocene and Quaternary silicoflagellates in sediments from the Mediterranean Sea. In Ryan, W.B.F., Hsü, K.-J., et al., Initial Reports of the Deep Sea Drilling Project, Volume 13: Washington (U.S. Government Printing Office), p. 837-883.

1973. Cenozoic endoskeletal dinoflagellates in southwestern Pacific sediments cored during Leg 21 of the DSDP. In Burus, R.E., Andrews, J.E., et al., Initial Reports of the Deep Sea Drilling Project, Volume 21: Washington (U.S. Government Printing Office), p. 819835. 
Edwards, A.R. and Perch-Nielsen, K., 1975. Calcareous Nannofossils from the Southern Southwest Pacific, DSDP, Leg 29. In Kennett, J.P., Houtz, R.E., et al., Initial Reports of the Deep Sea Drilling Project, Volume 29: Washington (U.S. Government Printing Office), p. 469540.

Ehrenberg, C.G., 1837. Die fossilen Infusorien und die lebendige Dammerde: Abhdlg. der Königl. Akad. d. Wissensch. zu Berlin.

, 1838. Uber die Bildung der u.s.w. - Kreidefelsen und des Kreidemergels durch unsichtbare Organismen. Abhdlg. d. Königl. Acad. d. Wissensch. zu Berlin, p. 59147.

1839. Uber noch jetzt zahlreich lebende Tierarten der Kreidebildung und den Organismen der Polythalamien: Abhdlg. d. Königl. Acad. d. Wissensch. zu Berlin, p. 81-174.

1840. Uber ausgezeichnete jetzt noch lebende peruanische und mexikanische Meeres-Infusorien, welche mit zur Erläuterung rätselhafter fossiler Formen der Kreidebildung dienen: Ber. über die zur Bekanntmachung geeigenten Verhdlg. d. Königl. preuss. Acad. d. Wissensch. zu Berlin, p. 157-162.

1841. Verbreitung und Einfluss des mikroskopischen Lebens in Süd- und Nordamerika: Abhdlg. d. Königl. Acad. d. Wissensch. zu Berlin. Theil 1, p. 291-445. 1843. Mitteilungen über 2 neue asiatische Lager fossiler Infusorien-Erden aus dem russischen TransKaukasien (Grusien) und Sibirien: Ber. über die zur Bekanntmachung geeigneten Verhdlg. der Königl. preuss. Acad. d. Wissensch. zu Berlin, p. 43-49.

1844. Mitteilung über 2 neue Lager von Gebirgsmassen aus Infusorien als Meeres-Absatz in Nordamerica und eine Vergleichung derselben mit den organischen Kreide-Gebilden in Europa und Afrika.-Ber. über die z. Bekanntmachung geeigneten Verhdlg. d. Königl. preuss Acad. d. Wissenschaften zu Berlin, p. 57-97. (Notice by J.W. Bailey, 1845. "Ehrenberg's Observations on the fossil Infusoria of Virginia and Maryland, and comparisons of the same with those found in the chalk formations of Europe and America": Amer. J. Sci., v. 48, p. 201-204).

1845. Nueu Untersuchungen über das kleinste Leben als geologisches Moment. Mit kurzer Charakteristik von 10 neuen Genera und 66 neuen Arten.-Ber. über die z. Bekanntmachung geeigneten Verhdlg. d. Königl. preuss. Acad. d. Wissensch. zu Berlin, p. 53-88.

1854. Mikrogeologie. Das Erden und Felsen schaffende Wirken des unsichtbar kleinen selbständigen Lebens auf der Erde.-Leopold Voss, Leipzig. Texte 374 S. (1854). Atlas, 40 Tafeln (1854) Forts. 885 (1856).

Fenner, J., in press. First results on the paleogeographic distribution of some selected late Eocene marine diatom species: Marine Micropaleontol.

Fenner, J., Schrader, H.-J., and Wienigk, H., 1976. Diatom phytoplankton studies in the southern Pacific Ocean. Composition, correlation to the Antarctic Convergence and its paleoecological significance. In Hollister, C.D., Craddock, C., et al., Initial Reports of the Deep Sea Drilling Project, Volume 35: Washington (U.S. Government Printing Office), p. 757-814.

Fillon, R.H., 1972. Evidence from the Ross Sea for widespread submarine erosion: Nature, Phys. Sci., v. 238, p. 40-42.

Forti, A., 1908. Primo elenco delle Diatomee fossili contenute nei depositi Miocenica di Bergonzano (Reggio d'Emilia). Nuova Notarisia, v. 19, p. 130-133, Luglio.

, 1909. Studi per una Monografia del genere Pyxilla
(Diatomee) e dei generi affini. In Nuova Notarisia, Serie XX, Padova, p. 5-24.

1910. Contribuzioni diatomologiche. IX. Cerataulus levis (H.L. Smith) Grun; Cerataulus polymorphus Grun. et V.H. e Cerataulus orbicularis n. sp., Loro revisione sistematica Cerataulus thermalis (Menegh.) Ralfs e sua vera natura.-Atti del Reale Inst. Veneto di Science, Lettere ed Arti, v. 69, p. 1249-1272.

1912. Primo elenco delle Diatomee fossili contenute nei calcari marnori biancastri di Monte Gibbio (Sassuolo-Emilia). Nuova Notarisia, ser. 23, p. 79-87. 1913. Contribuzioni diatomologiche. XIII. Diagnoses Diatomacearum quarumdam fossilium italiearum.-Atti del Reale Inst. Veneto di Scienze, Lettere ed Arti, v. 72, p. 1567-1700.

Foster, I. and Opdyke, N.D., 1970. Upper Miocene to Recent magnetic stratigraphy in deep-sea sediments: J. Geophys. Res., v. 75 , p. $4465-4474$.

Francheteau, I. and Le Pichon, X., 1972. Marginal fracture zones as structural framework of continental margins in south Atlantic Ocean: Am. Assoc. Petrol. Geol. Bull., v. 56, p. $991-1007$.

Frenguelli, I., 1949. Diatomeas fosiles de los yacimientos chilenos de iltil y Mejillones.-Darwiniana, v. 9, p. 97157.

Fryxell, G.G. and Hasle, G.R., 1972. Coscinodiscinae: some consistent patterns in diatom morphology. In Simonsen, R., ed.: Second Symposium on Recent and Fossil Marine Diatoms, London, Beihefte zur Nova Hedwigia, Heft. 45, p. 69-96.

Gaponov, 1927. Isokopaemie diatomovie vodorosli p.o. kamchatki. (Die fossilen Diatomeen der Halbinsel Kamschatka). Materialy po geologićeskij i polesn. iskop. Daln. Vost. v. 49, p. 5-28, Vladivostok.

Gasse, F., 1976. Ultrastructure de quelques Diatomées centriques fossiles d'Ethiopie, révélée par le Microscope électronique à balayage: Revue Algologique, Nouvelle Série, v. 11, p. 137-153.

Geizenauer, K.R., Margolis, S.V., and Edwards, D.S., 1968. Evidence consistent with Eocene glaciation in a South Pacific deep sea sedimentary core: Earth and Planet. Sci. Lett. 4, North-Holland Publ. Co., Amsterdam, p. 173177.

Girdler, R.W., 1963. Rift valleys, continental drift and convection in the earth mantle: Nature, No. 4885, p. 1037-1039.

Gleser, S.I., 1962. Species nova generis poretzkiae Jousé (Bacillariophyta) e depositionibus palaeoceni de clivitatis orientalis montium Uralensium. In Notulae systematicae e sectione cryptogamica Instituti botanici nomine V.L. Komarovii Acad. Scientiarum USSR, v. XV, p. 32-34.

1966. Silicoflagellatophyceae. Flora Plantarum cryptogamarum USSR, v. VII, p. 1-286.

1967. De Bacillariophytis, Sillicoflagellatis et Ebrideis in Aeocaeno Superiore Declivium Occidentalium Montium Mugodzharensium juventis. In Novitates systematicae Plantarum non Vascularium, Acad. Nauk, USSR, Moscow, p. 21-25.

1969. Posdueeozenowye kompleksy diatomowych kremnewych shgutikowych wodoroslej i ebriidej jugosapadnoj tschasti turgajskogo progiba. Biostratigrafitscheskij Sbornik Wyptschsk, v. 4, p. 67-84.

1970. The correlation of marine Eocene deposits of the eastern slope of the Urals, the western Siberia lowland and Turgai sag based on complexes of diatomic and silicoflagellate algae. Resolut. a. Transact. Interdepart. Confer. on Fishing and definition of unified and correlative stratigraphic schemes of the western Siberia lowland, Tyumen. 
1974. In Proschkina-Lavrenko (ed.), the diatoms of the USSR, Fossil and Recent, v. I, Leningrad, p. 109-146.

Gleser, S.I. and Jousé, A.P., 1974. Diatoms and silicoflagellates in the Eocene of the equatorial Atlantic. In Jousé, A.P. (ed.), Micropaleontology of oceans and seas. Acad. Nauk, USSR, Moscow, p. 49-62.

Gleser, S.I. and Posnova, A.N., 1964. Diatomeae novea marinae ex eoceno Kazachstaniae occidentalis. Nowosti sistematiki nisschich rastenij; Acad. Nauk, USSR, o delnyi ottisk, p. 59-66.

Gleser, S.I. and Rubina, N.W., 1968. Nowyi Paleogenowyja wid Diatomowoj wodorsli is Roda Coscinodiscus Ehr. In Trudy Tjumenskogo industrialuogo instituta, Wypusk I., p. $153-155$.

Gleser, S.I. and Sheshukova-Poretzkaya, V.S., 1967. De Speciebus Tertiariis Barbadossicis Ac Novozeelandicis in Aeoceno Superiore Ucrainae. In Novitates Systematicae Plantarum non Vascularium; Acad. Nauk, USSR, Moscow, p. 25-26.

1968. Late Eocene Bacillariophyta, Chrysophyta, Pyrrophyta and Ebriideae of the northeastern margin of the Ukrainian Crystalline Massif: Paleontologitscheskij Sbornik Wiptschsk Pjerwij No. 5, v. I, p. 117-123.

Gleser, S.I., Zosimovitch, V.U., and Klushnikov, M.N., 1965. Diatoms of Paleogene deposits in the North Donetz Basin and their stratigraphic position. Paleontol. Collec., Livov, v. 2, p. 73-82.

Göke, G., 1972. Das Vorkommen von Diatomeen im europaischen Paläogene: Der Aufschluss, 23 Jahrg, v. 11, p. 378-385.

Gombos, A.M., in press. Paleogene and Neogene diatoms from the Falkland Plateau and Malvinas Outer Basin. In Barker, P., Dalziel, I.W.D., et al., Initial Reports of the Deep Sea Drilling Project, Volume 36: Washington (U.S. Government Printing Office), p.

Gray, S.F., 1821. A natural arrangement of British plants according to their relations to each other as pointed out by Jussien, De Candolle, Brown, etc. including those cultivated for use; with an introduction to botany, in which the terms newly introduced are explained; illustrated by figures: Vol. 1, 824 p., 21 colored plates including frontis., and Vol. 2, 757 p.; Baldwin, Craddock, and Joy, London (Diatomaceae, p. 293-295).

Gregory, W., 1857. On new forms of marine Diatomaceae found in the Firth of Clyde and in Loch Fine: Trans. Roy. Soc. Edinburgh, v. 21, p. 473-542.

Greville, R.K., 1860. A monograph of the genus Asterolampra, including Asteromphalus and Spatangidium. Trans. Microscop. Soc. London, v. 8, new series, p. 102124.

1861a. Descriptions of new and rare diatoms, Series I. Trans. Microsc. Soc. London, v. 9, n.s., p. 39-47. $186 \mathrm{lb}$. Descriptions of new and rare diatoms, Series IV. Trans. Microsc. Soc. London, v. 9, n.s., p. 7887.

1861c. Descriptions of new and rare Diatoms. Series III. Trans. Microsc. Soc. London, v. 9, n.s., p. 7377.

1861d. Descriptions of new and rare diatoms, series

II. Trans. Microsc. Soc. London, v. 9, n.s., p. 67-73. 1862. Description of new and rare diatoms: Trans. Microsc. Soc. London, v. 10, ser. V, p. 18-29. 1862. Descriptions of new and rare diatoms: Trans. Microsc. Soc. London, v. 10, n.s., ser. VI, p. 89-96. 1862. Descriptions of new and rare diatoms: Quart. J. Microsc. Sci., v. 2, n.s., ser. VII, p. 231-237. 1863a. Descriptions of new and rare diatoms-Orig. Commun: In Quart. J. Microsc. Sci., v. 3, n.s., ser. X, p. 227-240. 1863b. Descriptions of new and rare diatoms: Trans. Microsc. Soc. London, v. 11, n.s., ser. IX, p. 6379.

1863c. Descriptions of new and rare diatoms: Trans. Microsc. Soc. London, v. 11, n.s., ser. VIII, p. 1322.

1864a. Descriptions of new and rare diatoms; Trans. Microsc. Soc. London, v. 12, n.s., ser. XI, p. 8-17. 1864b. Descriptions of new and rare diatoms: Trans. Microsc. Soc. London, v. 12, n.s., ser. XII, p. 8188.

1864c. Descriptions of new and rare diatoms: Trans. Microsc. Soc. London, v, 12, n.s., ser. XIII, p. 8797.

1865a. Descriptions of new and rare diatoms: Trans. Microsc. Soc. London, v. 13, n.s., ser. XIV, p. 137.

1865b. Descriptions of new and rare diatoms: Trans. Microsc. Soc. London, v. 13, n.s., ser. XV, p. 2437.

1865c. Descriptions of new and rare diatoms: Trans. Microsc. Soc. London, v. 13, n.s., ser. XVI, p. 4360.

1865d. Descriptions of new and rare diatoms: Trans. Microsc. Soc. London, v. 13, n.s., ser. XVII, p. $97-108$.

1866a. Descriptions of new and rare diatoms: Trans. Microsc. Soc. London. v. 14, n.s., ser. XVIII, p. 1-12.

1866b. Descriptions of new and rare diatoms: Trans. Microsc. Soc. London, v. 14, n.s., ser. XIX, p. 7788.

1866c. Descriptions of new and rare diatoms: Trans. Microsc. Soc. London, v. 14, n.s., ser. XX, p. 121130.

Grove, E. and Sturt, F.F.R.M.S., 1886. On a fossil marine diatomaceous deposit from Oamaru, Otago, New Zealand, Part I: J. Quekett Microscop. Club, Ser. 2, v. II, p. 321-332.

1887. On a fossil marine diatomaceous deposit from Oamaru, Otago, New Zealand, Part II: J. Quekett Microscop. Club, Ser. 2, v. III, p. 7-12.

1888. On a fossil marine diatomaceous deposit from Oamaru, Otago, New Zealand, Part III: J. Quekett Microscop. Club, Ser. 2, v. III, p. 63-78.

, 1889. On a fossil marine diatomaceous deposit from Oamaru, Otago, New Zealand; Appendix: J. Quekett Microscop. Club, Ser. 2, v. III, p. 131-148.

Grunow, A., 1862. Die österreichischen Diatomaceen nebst Anschluss einiger neuer Arten von anderen Lokalitäten und einer kritischen Ubersicht der bisher bekannten Gattungen und Arten. Erste Folge. Epithemieae, Meridioneae, Diatomeae, Entopyleae, Surirelleae, Amphipleuareae. Verhandl. der Kaiserlich-Königlichen Zoologischen-botan. Ges. in Wien, v. 12, p. 315-472. 1866. Moler aus Jutland eingesandt von Th. Jensen, analysiert von A. Grunow (über Sceptroneis? n. sp. Grun.): Hedwigia, v. 5, p. 145-146. 1867. Diatomeen auf Sargassum von Honduras, gesammelt von Lindia.-Hedwigia, v. 6, p. 1-8, 17-37. 1878. Einige Bemerkungen über die Diatomeen von P.T. Cleve und Moller: Am. Microsc. J., v. 3, p. 101. 1880. Bemerkung zu J. Brun's "Diatomeenflora der Alper." Bot. Centralblatt, v. 1, p. 248-255, Cassel. 1881. Uber die Arten der Gattung Grammatophora mit Bezug auf die Tafeln 53 and 53B in Van Heurck's synopsis der belgischen Diatomeen: Berl. Botanischen Zentralblatt, v. 7, p. 1-15.

1882. Beiträge zur Kenntnis der Fossilen Diatomeen Osterreich-Ungarns. In von Mojsisovids, E. 
and Neumayer, M., "Beiträge zur Palöontologie Osterreich-Ungarns und des Orients," v. II, p. 136-159. 1884. Diatomeen von Franz Josef-Land: Denkschriften der Kaiserlichen Akademie der Wissenschaften, v. 48 , p. 53-112.

1889. Some critical remarks by Herr A. Grunow on the Oamaru Diatom Papers of Messrs. Grove and Sturt: J. Queckett Microscop. Club, 2nd ser., v. 3, p. 387-391.

Gunter, H. and Ponton, G.M., 1933. Notes on the geology and the occurrence of some diatomaceous earth deposits of Florida: 23rd-24th An. Rep. Florida State Geol. Surv., p. 57-64.

Hajós, M., 1968. Die Diatomeen der Miozänen Ablagerungen des Mátravorlandes: Geologica Hungarica, Ser. Palaeontologica, Fasciculus 37, Budapest, 402 p.

1972. Faciological and stratigraphic importance of the Miocene diatoms in Hungary. In Simonsen, R. (ed.), 2nd Symp. Recent and Fossil Marine Diatoms, London, Beihft. z. Nova Hedwigia, Heft 45, p. 365-390.

1976. Upper Eocene and lower Oligocene Diatomaceae, Archaeomonadaceae, and Silicoflagellatae in southwestern Pacific sediments, DSDP Leg 29. In Hollister, C.D., Craddock, C., et al., Initial Reports of the Deep Sea Drilling Project, Volume 35: Washington (U.S. Government Printing Office), p. 817-884.

Hajós, M. and Stradner, H., 1975. Late Cretaceous Archaeomonadaceae, Diatomaceae, and Silicoflagellatae from the South Pacific Ocean, Deep Sea Drilling Project, Leg 29, Site 275. In Kennett, J.P., Houtz, R.E., et al., Initial Reports of the Deep Sea Drilling Project, Volume 29: Washington (U.S. Government Printing Office), p. 913-1009.

Hanna, G.D., 1927a. The lowest known Tertiary diatoms in California: J. Paleontol., v. I, p. 103-126. 1927b. Cretaceous diatoms from California: Occ. Pap. Calif. Acad. Sci., v. 13, San Francisco, p. 5-48. 1930a. A review of the genus Rouxia: J. Paleontol., v. 4 , p. $179-188$.

1930b. Observations von Lithodesmium cornigerum Brun: J. Paleontol., v. 4, p. 189-191. 1931. Diatoms and silicoflagellates of the Kreyenhagen Shale: Rep. State Mineralog., Calif., p. 187201.

1932. Pliocene diatoms of Wallace County, Kansas: Univ. Kansas Sci. Bull., v. 20, p. 369-394. 1933. Diatoms of the Florida peat deposits: 23rd24th Ann. Rep. Florida State Geol. Surv., p. 68-119. 1934. Additional notes on diatoms from the Cretaceous of California: J. Paleontol., v. 8, p. 352-355. 1936. Notes on localities of fossil diatoms in California: Soc. Trans. de Microscop. Bull., v. 5, p. 109 111.

1970. Fossil diatoms from the Pribilof Islands, Bering Sea, Alaska: Calif. Acad. of Sci. Proc., San Francisco, ser. 4, v. 37, p. 167-234

Hanna, G.D. and Brigger, A.L.. 1964. Some fossil diatoms from Barbados: Occ. Pap., Calif. Acad. Sci., No. 45, p. 27. 1965. A review of Kittonia, a genus of Diatoms: Occ. Papers Calif. Acad. Sci., p. 1-10.

Hanna, G.D. and Grant, W.M., 1926. Expedition to the Revillagigedo Islands, Mexico, in 1925. II. Miocene marine diatoms from Maria Madre Island, Mexico: Proc. Calif. Acad. Sci., ser. 4, v. 15, p. 115-193.

1931. Diatoms of Pyramid Lake, Nevada: Trans. Am. Microscop. Soc., v. 50, p. 281-297.

Hargraves, P.E., 1968. Species composition and distribution of net plankton diatoms in the Pacific sector of the Antarctic Ocean: Thesis, p. 1-170, 1 table.
Harland, W.B., Holland, C.H., House, M.R., Hughes, N.F., Reynolds, A.B., Rudwick, M.J.S., Satterthwaite, G.E., Tarlo, L.B.H., and Willey, E.C. (ed.), 1967. The Fossil Record. A symposium with documentation, 827 p.

Hasle, G.R., 1965. Nitzschia and Fragilariopsis species studied in the light and electron microscopes. III. The genus Fragilariopsis: Skrifter Utgitt av det Norske Videnskaps Acad. i Oslo, I. Mat.-Nat. Klasse. Ny Ser., No. 21,46 p.

1970. Two types of processes in centric diatoms: 1st Symp. Recent, Fossil Marine Diatoms: Bremerhaven, Beihft. z. Nova Hedwigia. Heft 39, p. 55-78.

1972a. Some marine plankton genera of the diatom family Thalassiosiraceae: 2nd Symp. Recent, Fossil Marine Diatoms, London, Beihft. z. Nova Hedwigia, Heft 45 , p. $1-68$.

1972b. The "Mucilage Pore" of pennate diatoms: 2nd Symp. Recent, Fossil Marine Diatoms: London, Beihft. z. Nova Hedwigia, Heft 45, p. 167-194.

Hasle, G.R. and Mendiola, de B.R.E., 1967. The fine structure of some Thalassionema and Thalassiothrix species: Phycologia, v. 6, p. 107-125.

Hayes, D.E., Frakes, L.A., et al., 1975. Initial Reports of the Deep Sea Drilling Project, Volume 28: Washington (U.S. Government Printing Office), p. 211-334.

Hays, J.D. and Berggren, W.A., 1971. Quaternary boundaries and correlations. In Funnel, B.M. and Riedel, W.R. (eds.) The micropaleontology of Oceans: Cambridge Univ. Press, p. 669-69?

Hays, J.D. and Opkyke, N.D., 1967. Antarctic radiolaria, magnetic reversals and climatic change: Science, v. 158 , p. 1001-1011.

Hays, J.D., Lozano, J.A., Shackleton, N.J., and Irving, G., 1976. An 18,000 B.P. reconstruction of the Atlantic and Indian sectors of the Antarctic Ocean: Geol. Soc. Am. Mem.

Heiberg, P.A.C., 1863. Conspectus criticus Diatomacearum Danicarum: Wilh. Priors F $\phi$ rlag, Kjфbenhaven, 135 p.

Heiden, H. and Kolbe, R.W., 1927. Die marinen Diatomeen der Deutschen Südpolarexpedition 1901-1903, v. 8, Bot. Heft 5, p. 447-745. , 1928.

Heirtzler, I.R., Dickson, G.O., Herron, E.M., Pittman, W.C., III, and Le Pichon, X., 1968. Marine magnetic anomalies, geomagnetic field reversals, and motions of the ocean floor and continents: J. Geophys. Res., v. 73, p. 2119-2136.

Hendey, I.N., 1937. The plankton diatoms of the southern seas: Discovery Rep., London, v. 16, p. 151-364. 1964. An introductory account of the smaller algae of British coastal waters, Part V: Bacillariophyceae (Diatoms): Fishery Investigations, Series IV, 317 p. 1969. Pyrgupyxis, a new genus of diatoms from a south Atlantic Eocene core. Occ. Pap. Calif. Acad. Sci., No. 72, San Francisco, p. 1-5. 1970. Muelleriella limbata (Ehrenberg) Van Heurck in Eocene South Atlantic Cores: 1st Symp. Recent Fossil Marine Diatoms, Bremerhaven, Beihft. z. Nova Hedwigia, Heft 39, p. 79-94.

1971. Electron microscope studies and the classification of diatoms. In Funnell, B.M. and Riedel, W.R. (ed.): The Micropaleontology of Oceans, Cambridge, p. 625-631.

1972. Some benthic diatoms from the coast of Cornwall in the neighbourhood of Porthleven: 3rd Symp. Recent, Fossil Marine Diatoms, London, Beihft. z. Nova Hedwigia, Heft 45, p. 291-327.

Hendey, I.N. and Wiseman, D.H., 1953. The significance and diatom content of a deep-sea floor sample from the 
neighbourhood of the greatest oceanic depth: Deep Sea Res., v. 1, p. 47-59.

Hertlein, L.G., 1933. Additions to the Pliocene fauna of Turtle Bay, Lower California, with a note on the Miocene diatomite: J. Paleontol., v. 7, p. 439-411.

Houtz, R. and Davey, F., 1973. Seismic profiles and Sonobuoy measurements in Ross Sea, Antarctica: J. Geophys. Res., v. 78, p. 34-48.

Hustedt, F., 1930. Die Kieselalgen Deutschlands, Osterreichs und der Schweiz mit Beruksichtigung der übrigen Länder Europas sowie der angrenzenden Meeresgebiete. In Rabenhorst, L., Kryptogamenflora von Deutschland, Osterreich und der Schweiz: v. VII, Teil 1, 920 p. 1958. Diatomeen aus der Antarktis und dem Südatlantik: Dtsch. Antarkt. Exped., v. 2, p. 105-191. 1959. Die Kieselalgen Deutschlands, Osterreichs und der Schweiz. 2. Teil, Bremen. In Rabenhorst, L., Kryptogamen flora von Deutschland, Osterreich und der Schweiz: v. 7, Teil 2, p. 737-845.

Ichikawa, W., 1960. On the fossil marine diatoms in the Wakura Beds, Noto Peninsula, Japan: The Sci. Rep. of the Kanazawa University, v. 7, p. 175-214.

Ikebe, N., Takayanagi, J., Chigi, M., and Chenzei, K., 1972. Neogene biostratigraphy and radiometric time scale of Japan. An attempt at internat. correlation: Pacific Geol., No. 4 , p. $39-78$.

Jenkins, O.P., 1931. Stratigraphic significance of the Kreyenhagen Shale: Min. in Calif., Calif. Dept. Nat. Res., Div. Mines, v. 27, p. 141-186.

John, G.R., 1936. The southern species of the genus Euphausia: Discovery Reports, v. 14, p. 193-324.

Johnson, G.L., Hey, R.N., and Lowrie, A., 1973. Marine geology in the environs of Bouvet Island and the South Atlantic triple junction: Marine Geophys. Res., v. 2, p. 23-36.

Jousé, A.P., 1949. Neue Diatomeen und Silicoflagellaten der oberen Kreide aus Tonsanden des Stromgebietes des grossen Aktai (Nordural). (Algae Diatomaceae Aetatis Superne Cretaceae ex Arenis Argillaceis Systematis). Botan. materialy otdela sporovych rastenij botan. instituta Akad. Nauk U.S.S.R., v. 6, p. 65-78.

1951a. Diatomeae aetatis Palaeoceani Ural Septentrionalis. Notulae Systematicae e Sectione Cryptogamica Instituti Botanici Nomine V.L. Komarovii Academiae Scientiarum U.R.S.S., v. 7, p. 24-42.

1951b. Diatomeae et Silicoflagellateae del abis Cretae superne e Montibus Uralensibus Septentrionalibus. Notulae Systematicae e Sectione Cryptogamic Instituti Botanici Nomine V.L. Komarovii, Academiae Scientiarum U.S.S.R., v. 7, p. 42-65.

1955. Neue Diatomeen aus dem Paläogen: Botan. materialy oldela sporovych rastenij botan. instituti Akademija Nauk U.S.S.R., v. 10, p. 81-103.

1957. Diatomowie w Powerchu ostuom sloe osadkow Ochotskogo Morja: Trudi Instituta Okeanologie, Moscow, v. 22, p. 164-220.

1959. Osnovnie etapi razbitija flori morskikh diatomovikh vodoroslei (Diatomeae) na Dalbuem Vostoke $v$ tretichnom i chetvertichnom periodakh. Bot Zhurn. (The main phases in the development of the flora of marine Diatoms in the far eastern seas of the U.S.S.R. at the end of the Tertiary, and during the Quaterny.) Bot. J. Acad. Sci. U.S.S.R., v. 44, p. 44-55.

1961. Diatomeae Marinae Mioceni et Plioceni ex

Oriente Extremo: Notulae Systematicae et Sectione Cryptogamica Instituti Botanici, Nomine V.L. Komarovii Acad. Sci. U.S.S.R., Acad. Nauk USSR, p. 59-70.

1962. Stratigraphische und paläogeologische Untersuchungen im Nordwestteil des Pacific. Acad. Nauk, Moscow, p. 258.
1963. Tip Bacillariophyta Obshchaya chasty. Sistematicheskaya chasty: class Centricae Bkn. Osnovi paleontologi Vodorosli. Moscow, Isclan. Acad. Nauk, U.S.S.R., p.

1965. Species Diatomearum Antarcticae Novae et Minus Cognitae: Novitates Systematicae Plantarum non Vascularium, Acad. Nauk, U.S.S.R., Moscow, p. 3-9. 1966. Diatomeen in Seesedimenten. In Elster, H.-J. and Ohle, W. (ed.): Ergebn. d. Limnologie, Hft. 4, p. 1-32. 1968a. Species Novae Bacillariophytorum in Sedimentis Fundi Oceani Pacifici et Maris Ochotensis Inventae: Novitates Systematicae Plantarum non Vascularium, Acad. Nauk, Moscow, p. 12-21. 1968 b. Old diatoms and diatom rocks of the Pacific basin: Lithology and Mineral Resources, Academy of Sciences of USSR, No. 1, p. 16-33. 1969a. Diatoms in the sediments of Pleistocene and late Pliocene of the Boreal Zone of the Pacific Ocean. Micropaleontology and Organogenous Sedimentation in the Oceans. Publ. Office Nauka, Moscow, p. 5-27. 1969b. Silicoflagellates in bottom sediments of Pleistocene and late Pliocene of the Pacific Ocean: Micropaleontology and Organogenous Sedimentation in the Oceans. Publ. Office Nauka, Moscow, p. 105-114. , 1971a. Species Formaeque Novae Et Curiosae Bacillariophytorum In Sedimentis Fundi Oceani Pacifici. In Novitates Systematicae Plantarum Non Vascularium, T. VIII, Acad. Nauk, U.S.S.R., Moscow, p. 12-18.

1971b. Diatoms in Pleistocene sediments from the northern Pacific Ocean. In Funnell, B.M. and Riedel, W.R. (ed.), The Micropaleontology of Oceans, Cambridge, p. 407-421.

1973. Diatoms in the Oligocene-Miocene Biostratigraphic Zones of the Tropical Areas of the Pacific Ocean: 2nd Symp. Recent Fossil Marine Diatoms, London, Beihft. z. Nova Hedwigia, Heft 45, p. 333-364. 1974. Diatoms in the Oligocene-Miocene biostratigraphic zones of the tropical areas of the Pacific Ocean. In Jousé, A.P. (ed.), Micropaleontology of Oceans and Seas, Acad. Nauk, U.S.S.R., Moscow, p. 34-48.

Jousé, A.P., Koroleva, G.S., and Nagaeva, G.A., 1963. Stratigraphical and paleogeographical investigations in the Indian Ocean section of the South Ocean: Acad. Sci. U.S.S.R. Soviet Geophysical Committee, no. 8, p. 137161.

Jousé, A.P., Kozlova, O.G., and Muhina, V.V., 1971. Distribution of diatoms in the surface layer of sediment from the Pacific Ocean. In Funnell, B.M. and Riedel, W.R. (ed.): The Micropaleontology of Oceans, Cambridge, p. 239-263.

Jousé, A.P. and Muhina, V.V., 1973. The Mesocena elliptica Ehr. Zone in the Pleistocene Sediments of the Pacific: Acad. Nauk U.S.S.R., Okeanologia, v. 13, p. 467-475.

Jousé, A.P. and Petrushevskaya, M.G., 1974. Diatoms and radiolarians in the Core St. 256 "OB" (Southern Ocean) Essay of Biostratigraphic Correlation. In Jousé (ed.), Micropaleontology of Oceans and Seas, Akad. Nauk U.S.S.R., p. 1-13.

Jousé, A.P. and Sheshukova-Poretzkaya, V.S., 1971. Genus novum Riedelia Jousé et Sheshukova-Poretzkaya (Bacillariophyta). Novitates System. Plantarum non Vascular., v. 8, p. 19-25.

Jurilj, A., 1957. Dijatomeje Sarmatskog Mora Okoline Zagreba. In Acta Biologica I, Zagreb, 153 p.

Kanaya, T., 1957. Eocene Diatom Assemblages from the Kellogg and "Sidney" shales, Mt. Diablo Area, California: Sci. Rep. Tohoku University, Sendai, Japan, 2nd ser. (Geol.), v. 28, 124 p.

1959. Miocene Diatom Assemblages from the Onnagawa Formation and their Distribution in the 
Correlative Formations in Northeast Japan: Sci. Rep. Tohoku University, Sendai, Japan, 2nd ser. (Geol.), v. 30, $130 \mathrm{p}$.

, 1971. Some aspects of pre-Quaternary diatoms in the oceans. In Funnell, B.M and Riedel, W. R. (Eds.), The Micropaleontology of Oceans, Cambridge, p. 545-565.

Kanaya, T. and Koizumi, I., 1966. Interpretation of diatom thanatocoenoses from the north Pacific applied to a study of core V 20-130 (studies of a deep-sea core V 20-130. Part IV): Sci. Rep. Tohoku Univ., Sendai, Japan, 2nd ser. (Geol.), v. 37, p. 89-130.

,1970. The progress in the younger Cenozoic diatom biostratigraphy in the northern Circum-Pacific Region: J. Marine Geol., v. 6, p. 47-66.

Kanaya, T., Kobayashi, T., Kitazawa, K., and Sakai, T., 1971. Magnetic and Micropaleontological study of deepsea sediments from the west-central equatorial Pacific: Deep Sea Res., v. 18, p. 1045-1062.

Karsten, G., 1905-1907. Wissenschaftliche Ergebnisse der Deutschen Tiefsee-Expedition auf dem Dampfer "Valdivia" 1898-99, herausgegeben von Karl Chun. Bd. II, Tl. III. G. Karsten: Das Phytoplankton des Antarktischen Meeres nach dem Material der Deutschen TiefseeExpedition 1898-99, S. 1-136, Taf. I-XIX. (1905). Das Phytoplankton des Atlantischen Ozeans nach dem Material der Deutschen Tiefsee-Expedition 1898-99, S. 137-219, Taf. XX-XXXIV (1906). Das indische Phytoplankton nach dem Material der Deutschen TiefseeExpedition 1898-1899, S. 221-548. Taf. XXXV-LIX (1907). Jena.

1928. Abteilung Bacillariophyta (Diatomeae). In Engler, A. and Prantl, K., "Die natürlichen Pflanzenfamilien," Auflage 2, Bd. 2, Peridineae (Dinoflagellatae), Diatomeae (Bacillariophytha), Myxomycetes, p. 105-345.

Kasarina, G.H. and Demidenko, E.L., 1974. Diatom and paleomagnetic zones in the sediments of Core St. 4599 (Indian Ocean). In Jousé, A.P. (ed.), Micropaleontology of Oceans and Seas, Acad. Nauk U.S.S.R., Moscow, p. 7693.

Keany, J. and Kennett, J.P., 1973. Pliocene-early Pleistocene paleoclimatic history recorded in Antarctic-subantarctic deep-sea cores: Deep-Sea Res., v. 19, p. 529-548.

Kennett, J.P., 1970. Pleistocene paleoclimates and foraminiferal biostratigraphy in subantarctic deep-sea cores: Deep-Sea Res., v. 17, p. 125-140.

Kent, D., Opdyke, N.D., and Ewing, M., 1971. Climate change in the North Pacific using ice-rafted detritus as a climatic indicator: Geol. Soc. Am. Bull., v. 82, p. 27412754.

Kitton, F., 1870/71. Diatomaceous deposits from Jutland, Part I. J. Quekett Mikroscop. Club, London, v. 2, p. 99102.

1871. Diatomaceous deposits from Jütland, Part 2. J. Quekett Microscop. Club, London, v. 2, p. 168-171.

Kobayashi, K., Kitazawa, K., Kanaya, T., and Saito, T., 1971. Magnetic and micropaleontological study of deepsea sediments from the west-central equatorial Pacific: Deep Sea Res., v. 18, p. 1045-1062.

Koizumi, I., 1968. Tertiary diatom flora of Oga Peninsula, Akita Prefecture, Northeast Japan: Sci. Rep. Tohoku Univ., 2nd ser. (Geol.), v. 40, p. 171-225.

1972. Marine diatom flora of the Pliocene Tatsunokuchi Formation in Fukushima Prefecture: Proc. Paleont. Soc. Japan Trans., N.S., No. 86, p. 304-359.

, 1973a. The late Cenozoic diatoms of Sites 183-193, Leg 19, Deep Sea Drilling Project: Inst, of Geol. Sci., College of Gen. Education, Osaka University, Toyonaka, Osaka, Japan, p. 805-855. 1973b. Marine diatom flora of the Pliocene Tatsunokuchi Formation in Miyagi Prefecture: Proc. Paleont. Soc. Japan Trans., N.S., No. 79, p. 126-136.

1975. Neogene diatoms from the northwestern Pacific Ocean, Deep Sea Drilling Project. In Larson, R.L., Moberly, R., et al., Initial Reports of the Deep Sea Drilling Project, Volume 32: Washington (U.S. Government Printing Office), p. 779-819.

Kolbe, R.W., 1954. Diatoms from equatorial Pacific cores: Rep. Swedish Deep-Sea Expedition, Göteborg, v. 6, 49 p.

Korenova, E.V., 1969. Palynological investigations of sediment cores from the Mediterranean Sea: Micropaleontology and Organogenous Sedimentation in the Oceans, Publ. Office Nauka, Moscow, p. 267-280.

Korenova, F.R. and Saidova, K.M., 1969. Sediments stratigraphy of the Eastern Mediterranean Sea by benthonic foraminifera: Micropaleontology and Organogenous Sedimentation in the Oceans, Publ. Office Nauka, Moscow, p. 188-199.

Kozlova, O.G., 1964. Diatomaceae of the Indian and Pacific parts of the Antarctic Ocean: Inst. Okeanologii, Acad. Nauk U.S.S.R., Moscow, 168 p.

, 1969. Quantitative distribution and species composition of diatoms and silicoflagellatae in the surface layer of sediments of the Indian Ocean: Micropaleontology and Organogenous Sedimentation in the Oceans, Publ. Office Nauka, Moscow, p. 28-51.

, 1971. The main features of diatom and silicoflagellate distribution in the Indian Ocean. In Funnell, B.M. and Riedel, W.R. (ed.): The Micropaleontology of Oceans. Cambridge, p. 271-275.

Krefft, G., 1958. Antarktische Fische und Fischlarven aus den Planktonfängen: Dtsch. Antarkt. Exped. 1938/39. Wissensch. Ergebn., v. 2, p. 249-256.

Krotov, A.I. and Shibkova, K.G., 1959. Neue Diatomeenarten aus dem Paläogen des Urals: Bot. mat. otd. spor. rast. bot. Inst. A.N. USSR 12, p. 112-129.

, 1961. Complexes of diatomic and silicoflagellate algae in the Upper Cretaceous, Paleogene and Neogene deposits of the eastern slope of the Urals and Transurals: Geological and paleontological materials, mineral resources of the Urals, v. 9, p.

Kruglikova, S.B., 1969. Radiolaria in the core of the Station 4066 (The northern part of the Pacific Ocean): Micropaleontology and Organogenous Sedimentation in the Oceans, Publ. Office Nauka, Moscow, p. 115-126.

Ku, T.-L., Broecker, W.S., and Opdyke, N.P., 1968. Comparison of sedimentation rates measured by paleomagnetic and the ionium methods of age determination: Earth and Planetary Sci. Letters, North-Holland Publ. Company, Amsterdam, v. 4, p. 1-16.

Kützing, F.T., 1833. Synopsis Diatomacearum oder Versuch einer systematischen Zusammenstellung der Diatomeen. Limnaea, v. 8, p. 529-620, Taf. 13-19. Berlin (Sonderabdruck), p. 1-29.

1844. Die Kieselschaligen Bacillarien oder Diatomeen. Nordhausen, 152 p. (1865).

Laporte, L.J. and Lefébure, P., 1929. Diatomées Rares et Curieuses: Paris, v. 1.

1930. Diatomées Rares et Curieuses: Paris, v. 2.

Le Pichon, X. and Hayes, D.E., 1971. Marginal offsets, fracture zones, and the early opening of the South Atlantic: J. Geophys. Res., v. 76, p. 6283-6293.

Leyden, R. and Nunes, G.R., 1974. Diapiric structures offshore Southern Brazil: Trans. 26th Brazilian Congress, p. 45-50.

Leyden, R., Asmus, H., Zembruscki, S., and Bryan, G., 1976. South Atlantic Diapiric structures: Am. Assoc. Petr. Geo. Bull., v. 60, p. 196-212. 
Lisitzin, A.P., 1969. The distribution of the remains of carbonate microorganisms in suspended matter and in the bottom sediments: Micropaleontology and Organogenous Sedimentation in the Oceans, Publ. Office Nauka, Moscow, p. 241-267.

Loeblich, A.R., Loeblich, L.A., Tappan, H., and Loeblich, A.R., Jr., 1968. Annotated index of fossil and Recent silicoflagellates and Ebridians with descriptions and illustrations of validly proposed taxa: Soc. Arm., Inc. Mem. 106, Colorado, 319 p.

Lohman, K.E., 1948. Middle Miocene diatoms from the Hammond Well. Cretaceous and Tertiary Subsurface Geol., Maryland Dept. Mines Geol. Bull., v. 2, p. 151186.

1974. Lower middle Miocene marine diatoms from Trinidad: Verh. Nat. Ges., Basel, p. 1-47.

Long, J.A., Fuge, D.P., Smith, J., 1946. Diatoms of the Moreno Shale: J. Paleont., v. 20, p. 89-118.

Loomis, T.P. and Morgan, W.J., 1973. Sea-floor spreading rate changes in the South Atlantic: Mar. Geophys. Res. (O. Reide Publ. Company, Holland), v. 2, p. 3-9.

Mackintosh, N.A., 1934. Distribution of the nannoplankton in the Atlantic Sector of the Antarctic: Discovery Rept., v. 9 , p. $65-160$.

1946. The Antarctic Convergence and the distribution of surface temperatures in Antarctic waters: Discovery Rept., v. 23, p. 177-212.

1964. Distribution of plankton in relation to the Antarctic Convergence: Proc. Roy. Soc. London, v. 281, p. 21-38.

Makarova, I.V., 1965. Novitates Florae Neogenae Diatomacearum Peninsulae Tasmanj. In Novitates Systematicae, Plantarum non Vascularium, Acad. Nauk, U.S.S.R., Moscow, p. 9-12.

1968. De Positione Systematica Generum Bacillariophytorum Naviculopsis Nik. et Diatomella Grev.: Novitates Systematicae Plantarum non Vascularium, Acad. Nauk, U.S.S.R., Moscow, p. 21-22.

Mann, A., 1907. Report on the diatoms of the Albatros Voyages in the Pacific Ocean, 1888-1904: Contr. from the United States Nat. Herbarium, Washington, v. 10, Part 5, p. $221-419$.

1925. Report of the Canadian Arctic Expedition, 1913-1918, Ottawa, v. 4, Part F: Mar. Diatoms, p. 3-33.

Martini, E., in press. In Talwani, M. Udintsev, G., et al., Initial Reports of the Deep Sea Drilling Project, Volume 38: Washington (U.S. Government Printing Office).

Martini, E. and Worsley, T., 1970. Standard Neogene calcareous nannoplankton zonation: Nature, v. 225, p. 289-290.

McCollum, D.W., 1975. Diatom stratigraphy of the Southern Ocean. In Hayes, D.E., Frakes, L. A., et al., Initial Reports of the Deep Sea Drilling Project, Volume 28: Washington (U.S. Government Printing Office), p. 515-572.

Mills, F., 1934. An Index of the genera and species of the Diatomaceae and their synonyms. 1816-1932, Part XVI, XVII, XVIII

Muhina, V.V., 1969. Biostratigraphy of sediments and some questions of paleogeography of the tropical region of the Pacific and Indian Oceans: Micropaleontology and Organogenous Sedimentation in the Oceans: Publishing Office Nauka, Moscow, p. 52-84.

1971. Problems of diatom and silicoflagellate Quaternary stratigraphy in the equatorial Pacific Ocean. In Funnell, B.M. and Riedel, W. R. (Eds.), The Micropaleontology of Oceans, Cambridge, p. 423-430.

1974. Diatoms in the suspension and surface sedimentary layer of the shelf of South-Western Africa. In Jousé, A.P. (Ed.), Micropaleontology of Oceans and Seas.
Akademia Nauk U.S.S.R., Moscow, p. 94-105.

Müller, C., in press. In Talwani, M. Udintsev, G., et al., Initial Reports of the Deep Sea Drilling Project, Volume 38: Washington (U.S. Government Printing Office).

Okeden, F.C.E., 1858. On the Diatomaceae of South Wales: Quart. J. Microscop. Sci., v. 6, p. 87-94.

Okuno, H., 1952. Atlas of fossil diatoms from Japanese diatomite deposits: Botanical Inst. Kyoto Univ. of Ind. Arts and Textile Fibers, Kamikyoku, Kyoto (Kawakita Printing Co.), 49 p.

Opdyke, N.D., 1972. Paleomagnetism of Deep Sea Cores: Reviews of Geophys. and Space Physics, v. 10, p. 213249.

Opdyke, N.D., Burckle, L.H., and Todd, A., 1974. The extension of the magnetic time scale in sediments of the central Pacific Ocean: Earth and Planetary Sci. Letters, v. 22 , p. $300-306$.

Pantocsek, J., 1886. Beiträge zur Kenntnis der fossilen Bacillarien Ungarns. v. I. Marine Bacillarien, 75 p.

1889. Beiträge zur Kenntnis der fossilen Bacillarien Ungarns. v. II: Brackwasser Bacillarien und Anhang: Analyse der marinen Depôts von Borny, Bremia VagyKürtös in Ungarn. Ananio und Kusnetzk in Russland. $123 \mathrm{p}$.

1892. Beiträge zur Kenntnis der fossilen Bacillarien Ungarns. v. III. Susswasser Bacillarien. Anhang-analysen 15 neuer Depôts von Bulgarien, Japan, Mähren, Russland und Ungarn, Vagy-Tapolcsany, Julius Platzko, 118 p.

Paramonova, N.V., 1964. Species Novae Diatomacearum ex Eoceni Sibiriae occidentalis: Novitates Systematicae Plantarum non Vascularium: Akad. Nauk, Inst. Bot. Nomine V.L. Komarovii, p. 66-68.

1965. Matériaux sur les Diatomées du Paléogène du Nord de la Sibérie occidentale: Trudy VNIGRJ USSR, Paläophyt. Sborn. 239, p. 232-246.

Payne, F.W., 1922. Liostephania and its allies. 30 p., 77 figs.

Peragallo, M., 1921. Botanique. Première Partie: Diatomées d'eau douce. Deuxième Partie: Diatomées d'eau saltée: Deuxième Expédition Antarctique Francaise (1908-1910) Commandée par le Dr. Jean Charcot. Ouvrage Publié sous les Auspices du Ministère de l'instruction Puplique. Masson and Cie, Editeurs, Paris, 98 p.

1897-1908. Diatomées Marines de France et des Districts Maritimes Voisins: Reimpression: Amsterdam (A. Asher and Co.), $491 \mathrm{p}$.

Perch-Nielsen, K., 1975. Late Cretaceous to Pleistocene Silicoflagellates from the southern southwest Pacific, DSDP, Leg 29. In Kennett, J.P., Houtz, R.E., et al., Initial Reports of the Deep Sea Drilling Project, Volume 29: Washington (U.S. Government Printing Office), p. 677722.

Petrushevskaya, M.G., 1969. Spumelline and Nasseline radiolarians in bottom sediments as water-masses indicators. Micropaleontology and Organogenous Sedimentation in the Oceans, Publishing Office Nauka, Moscow, p. 127-152.

Phillips, J.D. and Forsyth, D., 1972. Plate tectonics, paleomagnetism, and the opening of the Atlantic: Geol. Soc. Am. Bull., v. 83, p. 1579-1600.

Prinz, W., 1881. Etudes sur les coupes di Diatomées observées dans les lames minces de la roche de Nyk $\phi$ bing (Jütland): Roy. Microsc. Soc., v. 2, ser. 1, p. 507-509.

Prinz, W. and van Ermengem, E., 1883. Recherches sur la structure de quelques diatomées contenues dans le "Cementstein" du Jütland: Ann. Soc. belge Microscop., v. 8 , p. 7-74.

Pritchard, A., 1842-1852. A history of infusoria, living and fossil arranged according to "Die Infusionstierchen" of C.G. Ehrenberg: Leave out VIII, London, 439 p. 
1861. History of Infusoria, including the Desmidiaceae and Diatomaceae, British and Foreign, 4th ed., London, 40 p.

Proshkina-Lavrenko, A.I., 1949-1951. Diatomovyi analis. Vol. 1, 239 p.; Vol. 2, 238 p.; Vol. 3, 398 p.

1955. Relictae Diatomeae Planctoni E Maris Nigri: Notulae Systematicae e Sectione Cryptogamica Instituti Botanici nomine V.L. Komarovii Academiae Scientiarum URSS. Akademie Nauk, U.S.S.R., v. 10, p. 45-54.

1963. Diatomeen-Algen im Plankton des Asowschen Meeres: Akad. d. Wiss. d. U.S.S.R., Bot. V.L. Komarov-Institut, Moskau-Leningrad, 190 p.

Proshkina-Lavrenko (Ed.), 1974. The Diatoms of the USSR. Fossil and Recent: v. I, Leningrad, 372 p.

Ralfs, I., 1858. Notes on siliceous cell of Diatomaceae: Quart. J. Microscop. Sci., v. 6, p. 14-17.

Ramsay, A.T.S., 1971. Occurrency of Biogenic Siliceous Sediments in the Atlantic Ocean: Nature, v. 233, p. 115117.

Rand, W.W., 1931. Preliminary Report of the Geology of Santa Cruz Island, Santa Barbara County, Calif.: Mining in California, p.

Rattray, J., 1890. A Revision of the Genus Actinocyclus Ehrb: J. Queckett Microsc. Club, Ser. 2, v. 4, p. 137-212.

Reinhold, T., 1937. Fossil Diatoms of the Neogene of Java and their Zonal Distribution. In Verhandelingen van het Geologisch-Mijnbouwkundig Genotschap voor Nederland en Koloniën. Geologische Serie, Deel XII, p. 1-132.

1945. Het voorkomen van Diatomeen-Hondend Palaeocene-Eocene.

Reyment, R.A. and Tait, E.A., 1972-1973. Biostratigraphical dating of the early history of the south Atlantic Ocean: Phil. Trans. Royal Soc. London, ser. B, Biol. Sci., v. 264, p. 55-93.

Riedel, W.R. and Sanfilippo, A., 1970. Radiolaria, Leg 4, DSDP. In Bader, R.E., Gerard, R.D., et al., Initial Reports of the Deep Sea Drilling Project, Volume 4: Washington (U.S. Government Printing Office), p. 503576.

Roper, F.C.S., 1858. Notes on some new species and varieties of British marine diatomaceae: Quart. J. Microscop. Sci., v. VI, p. 17-25.

1859. On the Genus Biddulphia and its affinities. Trans. Microscop. Soc. London, v. 7, p. 1-24.

Ross, R., 1970. The current state of diatom taxonomy at the species level, with special reference to some species of Navicula, Sect. Lyratae: 1st Symp. Recent and Fossil Marine Diatoms, Bremerhaven, Bhft. z. Nova Hedwigia, Hft. 39, p. 1-36.

Ross, R. and Sims, P.A., 1973. Observations on family and generic limits in the Centrales: 2nd Symp. Recent and Fossil Marine Diatoms, London. Bhft. z. Nova Hedwigia, Hft. 45, p. 97-130.

Rubina, N.V. and Drosnes, M.A., 1961. Eocene deposits of the lower Pri.-Ob resolutions and transactions of interdepartmental conference on fishing and definition of stratigraphic schemes. The West Siberia Lowland, Leningrad.

Ruddiman, W.F., 1971. Pleistocene sedimentation in the equatorial Atlantic: stratigraphy and faunal paleoclimatology. Bull. Geol. Soc. Am., v. 82, p. 283-301.

Ryan, W.B.F., Cita, M.B., Rawson, M.D., Burckle, L.H., and Saito, T., 1974. A paleomagnetic assignment of Neogene stage boundaries and the development of isochronous datum planes between the Mediterranean, the Pacific and Indian Oceans in order to investigate the response of the World Ocean to the Mediterranean "Salinity Crisis": a new approach. Rev. Ital. Paleont. Strat., v. 80 , p. $212-257$.
Ryde, J.W., 1962. A study of Annellus californicus Tempère: J. Roy. Microscop. Soc., v. 80, p. 243-246.

Saidova, K.M., 1969. The paleogeography of benthonic foraminifera and stratigraphy of sediments of boreal and tropical regions of Pacific: Micropaleontology and Organogenous Sedimentation in the Oceans, Publishing Office Nauka, Moscow, p. 200-240.

Saito, T., 1969. Late Cenozoic stage boundaries in deep-sea sediments: Geol. Soc. Am. Abstracts for 1969, Part 7, p. 289-290.

Saito, T., Burckle, L.H., and Hays, J.D., 1975. Late Miocene to Pleistocene biostratigraphy of equatorial Pacific sediments. In Saito, T. and Burckle, L.H. (Eds.), Late Neogene Epoch Boundaries (24th Internat. Geol. Congr., Montreal, 1972, Symposium 109), Amer. Mus. Nat. Hist. Micropal. Press, Spec. Publ. 1, p. 6-36.

Sawamura, K., 1963. On the correlation of the Miocene of the Joban, Tomamae coal fields and that of east Hokkaido: Geol. Surv. Japan Bull., v. 14, p. 91-94.

Schmidt, A., et al., 1874-: Atlas der Diatomeen-Kunde: v. 1120 , continued by M. Schmidt, F. Fricke, H. Heiden, O. Müller, and F. Hustedt.

Schrader, H.-J., 1969. Die Pennaten Diatomeen aus dem Obereozän von Oamaru, Neuseeland: Beihft. z. Nova Hedwigia, Heft 28, p. 1-124. 1970. Anlösung und Konservation von Diatomeenschalen beim Absinken am Beispiel des LandsortTiefs in der Ostsee: 1st Symp. Recent Fossil Marine Diatoms, Bremerhaven, Beihft. z. Nova Hedwigia, Heft 39 , p. $191-216$.

1973a. Cenozoic diatoms from the northeast Pacific, Leg 18. In Kulm, L.D., von Huene, R., et al., Initial Reports of the Deep Sea Drilling Project, Volume 18: Washington (U.S. Government Printing Office), p. 673-797.

1973b. Types of raphe structures in the diatoms: 2nd Symp. Recent and Fossil Marine Diatoms, London, Beihft. z. Nova Hedwigia, p. 195-217.

1973c. Proposal for a standardized method of cleaning diatom-bearing deep-sea and land-exposed marine sediments: 2nd Symp. Recent and Fossil Marine Diatoms Proc., London, Nova Hedwigia, Beihefte Nr. 45, p. $403-409$.

1974a. Cenozoic marine planktonic diatom stratigraphy of the tropical Indian Ocean. In Fisher, R.L., Bunce, E.T., et al., Initial Reports of the Deep Sea Drilling Project, Volume 24: Washington (U.S. Government Printing Office), p. 887-967.

1974b. Morphologisch-systemat ische Untersuchungen an Diatomeen. I. Die Gattungen Ostrupia Heiden, Progonia Schrader, Caloneis Cleve. Nova Hedwigia XXII, p. 915-928.

1976. Cenozoic planktonic diatom biostratigraphy of the Southern Pacific Ocean. In Hollister, C.D., Craddock, C., et al., Initial Reports of the Deep Sea Drilling Project, Volume 35: Washington (U.S. Government Printing Office), p. 605-672.

Schrader, H.-J., in preparation. Leg 41.

Schrader, H.-J. and Fenner, J., in press a. Norwegian Sea Cenozoic Diatom Biostratigraphy. In Talwani, M., Udintsev. G., et al., Initial Reports of the Deep Sea Drilling Project, Volume 38.

in press b. Diatoms at DSDP Leg 38, taxonomic references. In Talwani, M., Udintsev, G., et al., Initial Reports of the Deep Sea Drilling Project, Volume 38: Washington (U.S. Government Printing Office).

Schubert, K., 1958. Wale, Robben und Vögel: Deutsche Antarktische Expedition 1938/39. Wissenschaftl. Ergebnisse, v. 2, p. 257-275. 
Schulz, P., 1927. Diatomeen aus nordeutschen Basalttuffen und Tuffgeschieben: Zeitschr. f. Geschiebeforschung, v. 3, p. 66-78, 113-126.

1935. Diatomeen aus senonen Schwammgesteinen der Danziger Bucht. Zugleich ein Beitrag zur Entwicklungsgeschichte der Diatomeen: Bot. Arch., Leipzig, v. 37, p. 383-413.

Shackleton, N.J. and Kennett, J.P., 1975. Paleotemperature history of the Cenozoic and the initiation of Antarctic Glaciation: Oxygen and Carbon isotope analyses in DSDP Sites 277, 279, and 281. In Kennett, J.P., Houtz, R.E., et al., Initial Reports of the Deep Sea Drilling Project, Volume 29: Washington (U.S. Government Printing Office), p. 743-756.

Sheshukova-Poretzkaya, V.S., 1964. Diatomeae mannae novae et rarae e neogeno insulae Sochalen et peninsulae Kamz at ha: Nov. Systematicae Plantarum non Vascularium (Acad. Sci. URSS Inst. Bot. Nom. V.L. Komarovii), p. 69-72.

1967. Neogene marine diatoms of Sakhalin and Kamchatka: Izd. Leningr. Univ., 327 p.

Sheshukova-Poretzkaya, V.S. and Gleser, S.I., 1962. Bacillariophyta, Silicoflagellata and Ebriideae from Maikop series deposits (River Shibik, Krasnodar Region). (Diatomovie vodorosli, silikoflagellatii ebriidei iz maikopsikh otloznenii s.v. Shibik [Krasnodarski Krai]). Uchenie Zapiskilgu, Serij biolog. Nauk (Leningrad Univ.), v. 49 , p. $171-202$

1964. Diatomeae marinae novae e Palegeno Ucraineae: Acad. Nauk U.S.S.R., Novosti sistematiki nizschich rastenij otdel bentii o Hisk, isdatelbstwo Nauka, p. 78-92.

Sheshukova-Poretzkaya, V.S. and Moissejewa, A.I., 1964. Novie i interesnie presnovodnie diatomovie vodorosli iz neogena Zapadnoi sbiri idalnego vosloka (Diatomeae Aquae dulcis novae et curiosae e neogeno sibiriae occidentalis et orientis extremi). Novosti systematiki nizschikh Rastenij, Acad. Nauk U.S.S.R., botanicheskij inst. im. V.L. Komarova (Acad. Sci. U.S.S.R.) Institutum Botanicum Nomine V.L. Komarovii, p. 92-103.

Shibkova, K.G., 1968. Paleogene Bacillariophyta of South Kazakstan. In Jousé, A.P. (ed.), Iskopaemye diatomovye vodorosli U.S.S.R., AN U.S.S.R., sibirskoe ot del., Inst. Geol. Geof., p. 21-26.

Shrubsole, W.H. and Kitton, F., 1881. The diatoms of the London Clay: J. Roy. Microscop. Soc., v. 1, p. 381-387.

Simonsen, R., 1970a. Ideas for a more natural system of the centric diatoms: 1st Symp. Recent, Fossil Marine Diatoms, Bremerhaven, Beihft. z. Nova Hedwigia, Heft 39 , p. $37-54$.

1970b. Nitzschiaceae versus Bacillariaceae: 1st Symp. Recent, Fossil Marine Diatoms, Bremerhaven, Beihft. z. Nova Hedwigia, Heft 39, p. 121-126.

1974. The diatom plankton of the Indian Ocean Expedition of R.V. Meteor 1964-1965: "Meteor" ForschErgebn. Reihe D, v. 19, p. 1-65.

1975. On the pseudonodulus of the centric diatoms, or Hemidiscaceae reconsidered: 3rd Symp. Recent, Fossil Marine Diatoms, Kiel, Beihft. z. Nova Hedwigia, Heft 53, p. 83-98.

Simonsen, R. and Kanaya, T., 1961. Notes on the marine species of the diatom genus Denticula Kütz: Internationale Revue der gesamten Hydrobiologie, v. 46, Hft. 4, p. 498513.

Simonsen, R., Schrader, H.-J., 1974. On the fine structure of the centric diatom Craspedoporus elegans Grove and Sturt: 2nd Symp. Recent, Fossil Marine Diatoms, London, Beihft. z. Nova Hedwigia, Heft 45, p. 147-158.

Smith, W., 1853-1856. A synopsis of the British diatomaceae; with remarks on their structure, function and distribution; and instructions for collecting and preserving specimens. v. 1,89 p; v. 2,107 p.

Stadel, O., 1958a. Die Chaetognathen-Ausbeute: Dtsch. Antarkt. Exp. 1938/39. Wiss. Ergebn., v. 2, p. 208-244. 1958b. Die Salpen: Dtsch. Antarkt. Exp. 1938/39. Wiss. Ergebn., v. 2, p. 199-207.

1958c. Die Decapodenlarven: Dtsch. Antarkt. Exp. $1938 / 39$. Wiss. Ergebn., v. 2, p. 192-198. 1958d. Die biologischen Arbeiten der Deutschen Antarktischen Expedition 1938/39: Dtsch. Antarkt. Exp. 1938/39. Wiss. Ergebn., v. 2, p. 101-102.

Stolley, E., 1899. Uber Diluvialgeschiebe des Londonthons in Schleswig-Holstein und das Alter der Molerformation sowie das baltische Eozän uberhaupt: Archiv Anthropol. Geol. Schleswig-Holstein, v. 3, p. 106-146.

Strelnikova, N.I., 1971. Species Novae Bacillariophytorum e sedimentis cretae posterioris in declivitate orientali partis polaris ec praepolaris montium uralensium: Novitates systematicae Plantarum non Vascularium, v. 8, p. 41-52. 1974. Diatomei pozdnego mela (Late Cretaceous diatoms of western Siberia): Acad. Nauk, U.S.S.R., Roy 8 , p. 202.

Strelnikova, N.I., Koslova, O.G., 1974. Diatoms in the plankton, suspended matter and bottom sediments of the northeastern part of the Pacific. In Jousé, A.P. (ed.), Mikropaleontology of Oceans and Seas: Acad. Nauk, U.S.S.R., Moscow, p. 63-75.

Tempère, J. and Peragallo, H., 1889-1895. Diatomées collection, J. Tempère and $\mathrm{H}$. Peragallo: 8 supplements, $304+62$ pages.

1907-15. Diatomée du Monde Entier, Edition 2, 30 fascicules. Arcachon, Paris(?), France. Fascicule 1: p. 116, (1907); 2-7 p. 17-112, (1908); 8-12, p. 113-208, (1909); $13-16$, p. $209-256,(1910)$; $17-19$, p. $257-304,(1911) ; 20-23$, p. $305-352$, (1912); $24-28,353-448$, (1913); 29-30, p. 449480, (1914); Tables and index, p. 1-68, (1915). Exsiccata Slides 1-1000, (1915).

Theyer, F. and Hammond, S.R., 1974a. Cenozoic magnetic time scale in deep-sea cores; completion of the Neogene: Geology, p. 487-492.

1974b. Paleomagnetic polarity sequence and radiolarian zones Brunhes to polarity epoch 20: Earth Planetary Sci. Lett., v. 22, p. 307-319.

Thompson, C.W. and Murray, F., 1895. Scientific results of the voyage of H.M.S. Challenger during the years 18721876.

Toni, I. B., de, 1891-1894. Sylloge algarum omnium hucusque cognitarum, Vol. II. Bacillarieae. Sectio I, Raphideae, p. 1-490 (1891) Sectio II, Pseudoraphideae, p. 491-817 (1892). Sectio III, Cryptoraphideae, p. 818-1556 (1894). Typis Seminarii, Patavii.

Truan y Luard, A. and Witt, O.N., 1888. Diatomaceen der Polycystinen Kreide von Jérémie in Haiti, Westindia. Berlin: J. Micrograph., Ann., v. 12, p. 162.

Tsumura, K., 1959. Preliminary report on Goniothecium: Bull. Yokohama Municipal Univ. Soc., v. 10, p. 69-83. 1963. Figuraro de kelke da specimeno de Pyxilla kaj aliaj genroj konservitaj de mi. Bull. Yokohama Municipal Univ. Soc., v. 14, p. 68-93.

Ushakova, M.G., 1969. Coccoliths in the suspension and surface sedimentary layer of the Pacific and Indian Oceans: Micropaleontology and Organogenous Sedimentation in the Oceans, Publ. Office Nauka, Moscow, p. 96-104.

Van Ermengem, E., 1885. Discussion sur la structure de quelques Diatomées dans le Cementstein du Jutland etc.: Ann. Soc. belge Microscop., v. 10, p. 79-86.

Van Heurck, H., 1880-1885. Synopsis des Diatomées de Belgique. Atlas, pl. 1-30 (1880); pl. 31-77 (1881); pl. 78-103 (1882); pl. 104-132 (1883); pl. A,B,C (1885). Ducaju \& 


\section{J. FENNER}

Cie, Anvers. Table Alphabetique (Index), J.F. Dieltreus, Anvers, 120 p. (1884), Texte, Mtin., Brouwers \& Co., Anvers, 235 p. (1885).

1893. Types du Synopsis des Diatomées de Belgique. Serie I-XXII. Exsicata. Anvers 1884 et seq. (Slides issued at sporadic intervals). Referat: Botan. Centralbl., v. 33 , p. 323 , etc. $556 \mathrm{p}$.

1896. A Treatise on the Diatomaceae, London,

Van Landingham, S.L., 1967. Paleoecology and microfloristics of Miocene diatomites from the Otis BasinJuntura Region of Harney and Malheur Counties, Oregon: Beihft. zur Nova Hedwigia, Hft. 26, Monroe, Louisiana, p. 1-77.

1967. Catalogue of the fossil and Recent genera and species of diatoms and their synonyms. A revision of F.W. Mills', "An Index to the Genera and Species of the Diatomaceae and their Synonyms": Verlag von J. Cramer, Lehre.

Villwock, W., 1958. Kurze Mitteilung über die Polychaeten. In Dtsch. Antarkt. Exped. 1938/39. Wissenschaftl. Ergebn., v. 2, 3. Lief., Hamburg, p. 245-248.

Vonsen, M. and Hanna, G.D., 1936. Borax Lake, California: Calif. J. Mines and Geology, Rep. 32.

Wallich, G.C., 1858. On Triceratium and some new allied forms with figures of the same: Quart. J. Microscop. Sci., v. 6 , p. $242-253$.

1860. On the siliceous organisms found in the digestive cavities of the Salpae and their relations to the flint nodules of the Chalk Formation: Trans. Microsc. Soc. London, v. 8, n.s., p. 36-55.

Walker-Arnott, G.A., 1858a. On Arachnoidiscus: Quart. J. Microscop. Sci., v. 6, p. 159-165.

1858b. Notes on Arachnoidiscus, Pleurosigma, Amphiprora, Eunotia, and Amphora: Quart. J. Microscop. Sci., v. 6, p. 195-206.

Watkins, N.D. and Richardson, A., 1968. Comments on the relationship between magnetic anomalies, crustal spreading and continental drift. Earth Planetary Sci. Lett., v. 4 , p. $257-264$.
Weisse, J.F., 1854. Mikroskopische Analyse eines organischen Polierschiefers aus dem Gouvernement Simbirsk von Dr. J.F. Weisse: Mélange Biologiques tires du Bulletin de l'Academie Imp. des Sci. de St. Petersburg, v. 2 , p. $237-250$.

Wetzel, O., 1935. Die Mikropaläontologie des Heiligenhafener Kieseltones (Ober-Eozän): Jahresber. niedersächs. geol. Vereinig., v. 27, p. 41-75.

Wieseman, J.D.H. and Hendey, I., 1953. The significance and diatom content of a deep-sea floor sample from the neighbourhood of the greatest oceanic depth: Deep Sea Res., v. 1, p. 47-59.

Williams, D.F., 1976. Late Quaternary fluctuations of the Polar Front and Subtropical Convergence in the Southeast Indian Ocean: Marine Micropaleontol., v. 1, p. 363-395.

Witt, O.N., 1886. Uber den Polierschiefer von Archangelsk: Kurojedowo im Gouvernement Simbirsk, 41 p.

Wilson, J. Tuzo, 1963. Hypothesis of earth's behaviour. Nature, No. 4884 , p. $925-929$.

1965. A new class of faults and their bearing on continental drift: Nature, No. 4995, p. 343-347.

Wornardt, W.W., Jr., 1964. Pleistocene diatoms from Mono and Panamint Lake Basins, California: Occ. Papers Calif. Acad. Sci., No. 46, San Francisco, 27 p.

1967. Miocene and Pliocene marine diatoms from California: Occ. Papers Calif. Acad. Sci., No. 63, San Francisco, $108 \mathrm{p}$. 1974. Correlation of the Neostratotype of the Messinian Stage Capodarso and Pasquasia Sections Based on Diatoms: 2nd Symp. Recent Fossil Marine Diatoms, London, Beihft. z. Nova Hedwigia, Heft 45, p. 391-402.

Wüst, G., 1957. Quantitative Untersuchungen zur Statik und Dynamik des Atlantischen Ozeans. Stromgeschwindigkeiten und Stromengen in den Tiefen des Atlantischen Ozeans: Wiss. Ergeb. Deutsche Atl. Exp. Meteor, 1925-1927, v. 6, 420 p.

Zabelina, E.K., 1969. Diatoms in the sediments of the northern part of the White Sea: Micropaleontology and Organogenous Sedimentation in the Oceans, Publ. Office Nauka, Moscow, p. 85-95. 



\section{PLATE 1 \\ Magnification $1500 \times$}

Figure 1 Hemidiscus cuneiformis Wallich (1860).

Sample 358-2-4, 30-31 cm.

Figure 2 Genus and species indet.

Sample 356-8-1, 51-52 cm.

Figure 3 Hemidiscus karstenii Jousé (1962).

Sample 358-1-1, 30-31 cm.

Figures 4, $5 \quad$ Stictodiscus sp.

4. Sample 356-7-5, 30-31 cm.

5. Sample $356-7-2,30-31 \mathrm{~cm}$.

Figure 6 Coscinodiscus praenitidus Fenner and Schrader (in press, b).

Sample 356-9-2, 30-31 cm.

Figure $7 \quad$ Stictodiscus sp. 1.

Sample 356-6-2, 30-31 cm.

Figure $8 \quad$ Coscinodiscus lentiginosus Janisch (1878). In Schmidt et al. (1874-).

Sample 358-1-3, 30-31 cm.

Figure 9 Coscinodiscus praenitidus Fenner and Schrader (in press, b).

Sample 356-7-6, 30-31 cm.

Figure $10 \quad$ Pseudostictodiscus picus Hanna.

Sample 356-6-2, 30-31 cm.

Figures 11-13 Coscinodiscus lentiginosus Janisch (1878). In Schmidt et al. (1874-).

11. Sample 358-1-1, 30-31 cm.

12. Sample 358-1-2, $30-31 \mathrm{~cm}$.

13. Sample $358-1-3,30-31 \mathrm{~cm}$.

Figure 14 Stictodiscus californicus var. nitida Grove and Sturt (1887).

Sample 356-8-1, $51-52 \mathrm{~cm}$.

Figure 15 Coscinodiscus praenitidus Fenner and Schrader (in press, b).

Sample $356-6-2,30-31 \mathrm{~cm}$. 
PLATE 1

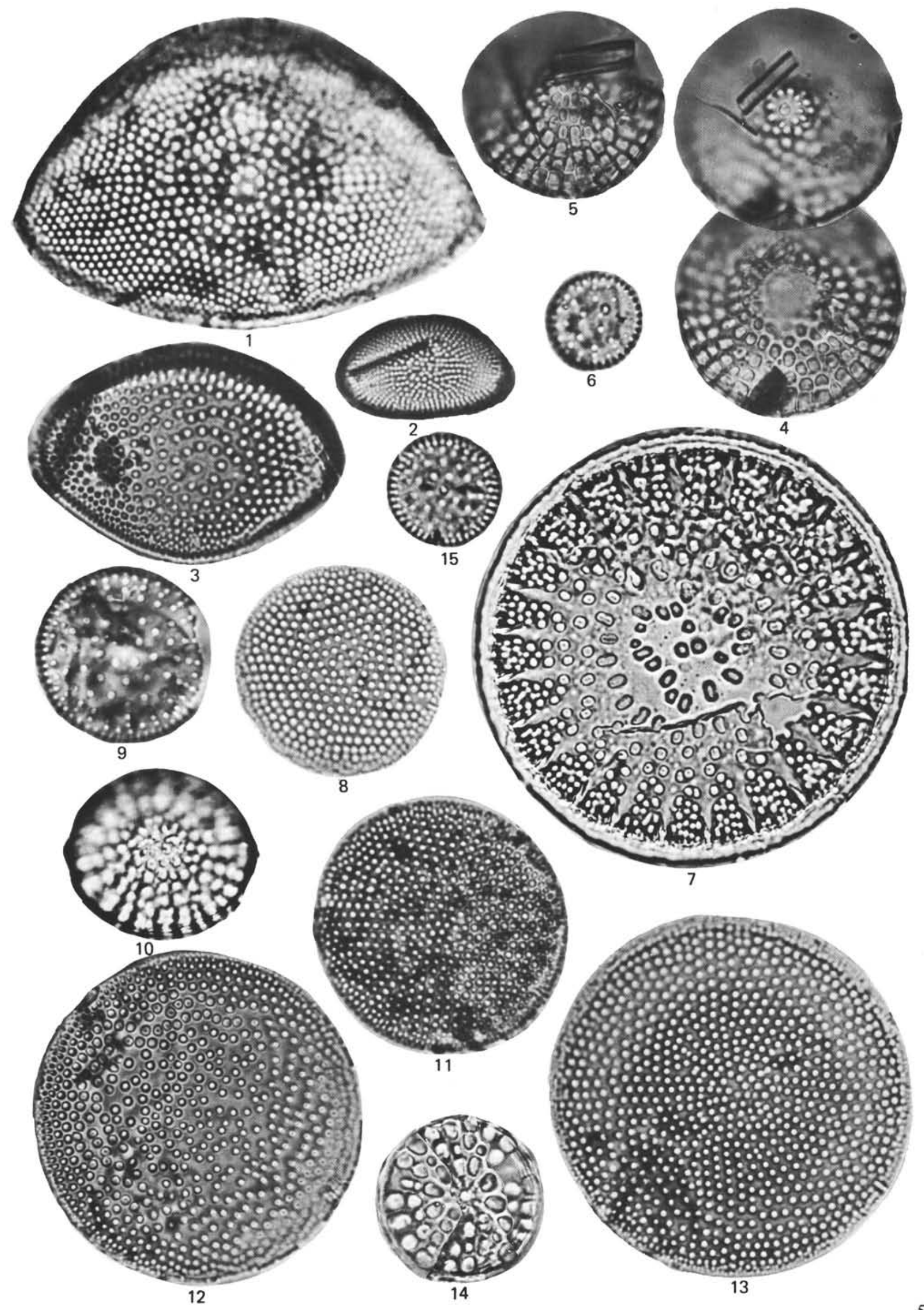


PLATE 2

Magnification $1500 \times$, except Figures 1, 5, 1200×

Figure $1 \quad$ Kozloviella sp.

Sample 354-12-6, 40-41 cm, 1200×.

Figures 2-3 Coscinodiscus bulliens Schmidt (1878).

2. Sample 354-12-3, $49-50 \mathrm{~cm}$.

3. Sample $356-6-3,30-31 \mathrm{~cm}$.

Figure 4 Brightwellia hyperborea Grunow in Van Heurck (1883). Sample 354-12-3, 2-3 cm.

Figure $5 \quad$ Brightwellia coronata (Brightw.) Ralfs in Pritchard (1861). Sample 356-6-4, 30-31 cm. 
PLATE 2
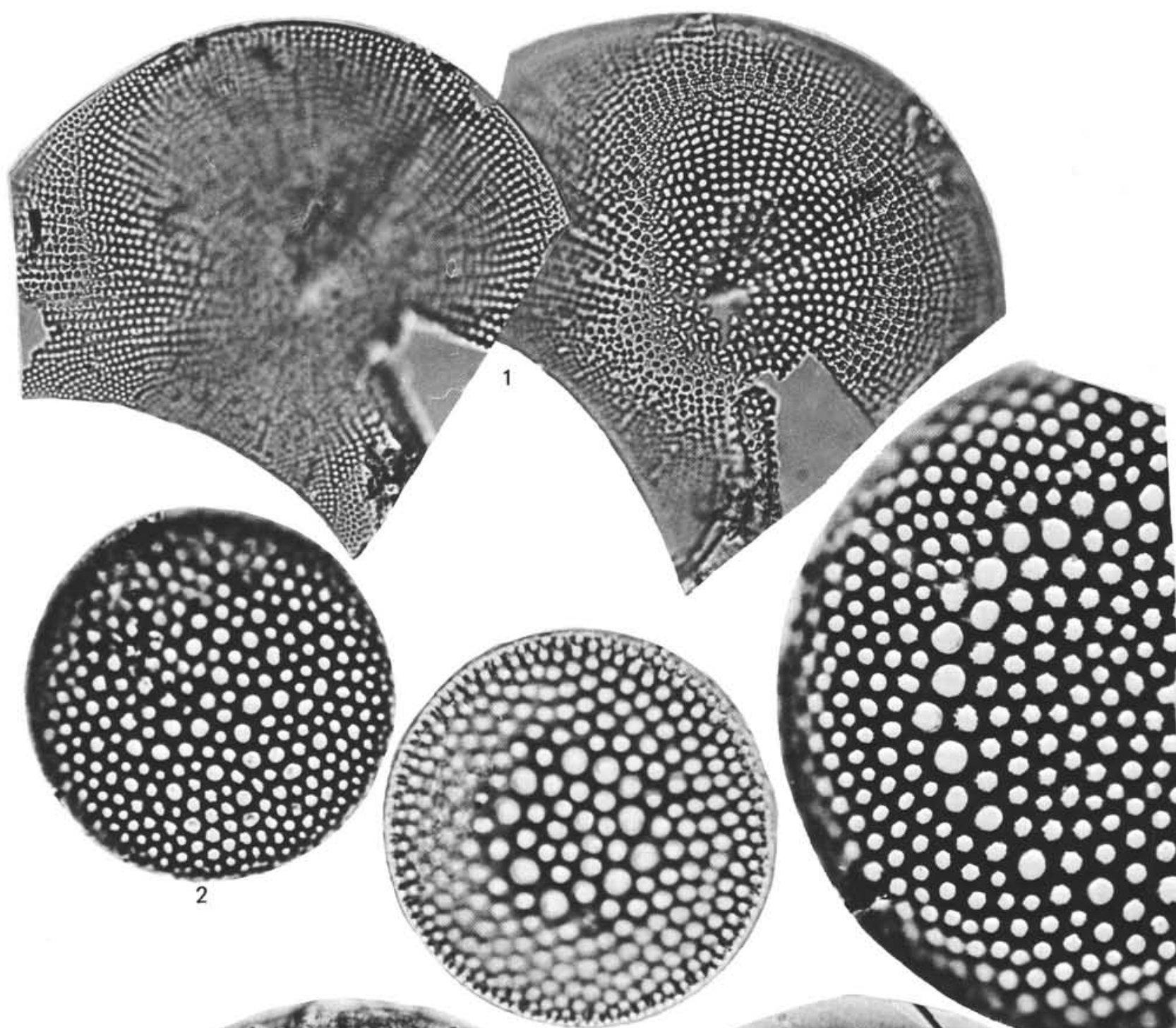

0.0. 000
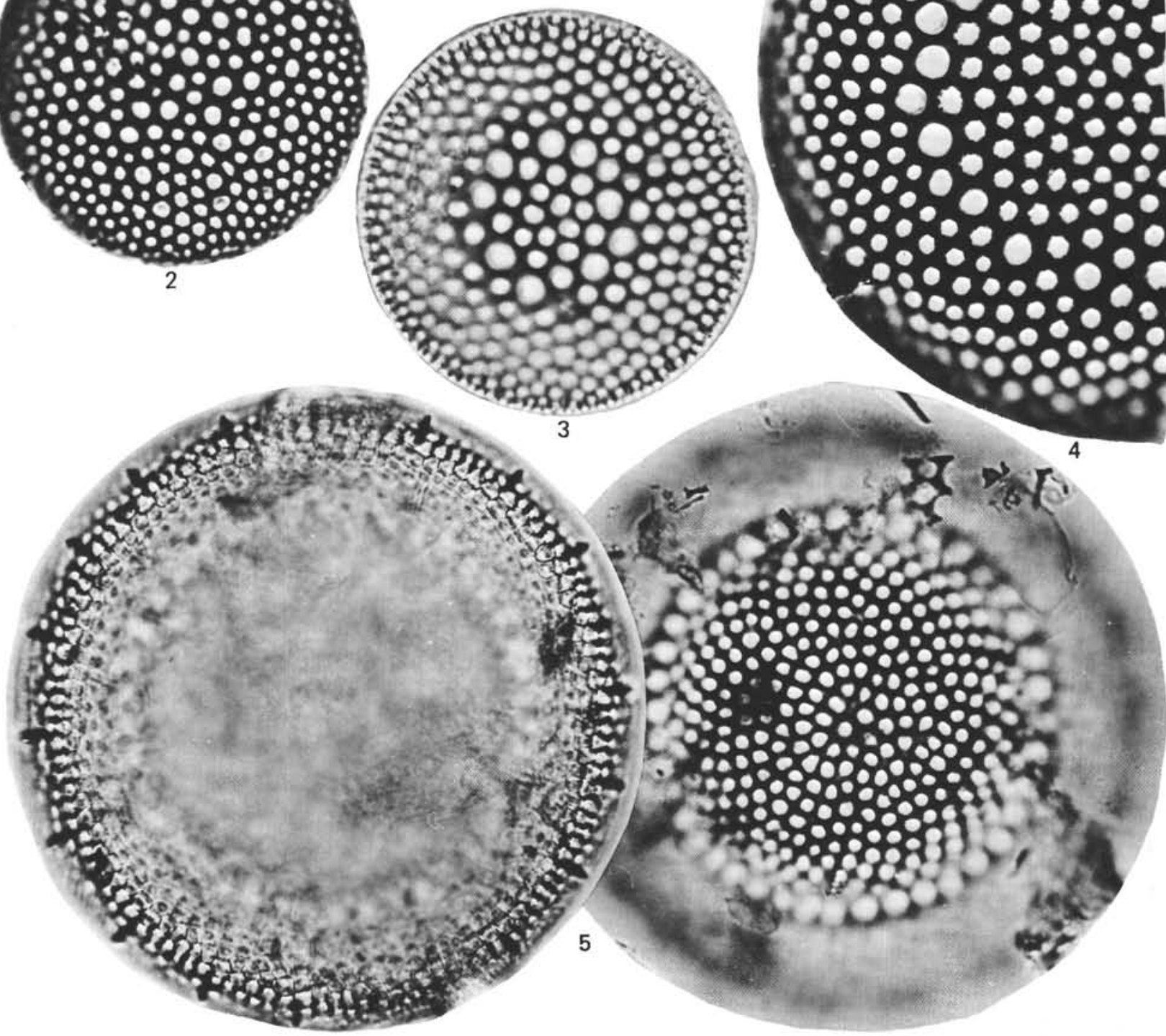

${ }^{4}$ 
PLATE 3

Magnification $1500 \times$, except Figure 1, 750×

Figure $1 \quad$ Brightwellia coronata (Brightw.) Ralfs In Pritchard (1861).

Sample 356-9-2, $30-31 \mathrm{~cm}, 750 \times$.

Figure $2 \quad$ Coscinodiscus sp. 6.

Sample 356-8-2, 30-31 cm.

Figure 3 Cosinodiscus praenitidus Fenner and Schrader (in press).

Sample $356-7-2,30-31 \mathrm{~cm}$.

Figure 4 Glyphodiscus sp.

Sample $356-8-1,51-52 \mathrm{~cm}$.

Figure 5 Stictodiscus californicus var. nitida Grove and Sturt (1887).

Sample 356-9-2, 30-31 cm.

Figure $6 \quad$ Coscinodiscus sp. 7.

Sample 356-7-6, 30-31 cm.

Figures 7-8 Thalassiosira? sp. 1.

7. Sample $354-12-3,2-3 \mathrm{~cm}$.

8. Sample $356-6-3,30-31 \mathrm{~cm}$.

Figure 9 Coscinodiscus sp. 7.

Sample $356-7-5,30-31 \mathrm{~cm}$.

Figure 10 Melosira sulcata (Ehr.) Kützing (1844),

Sample 356-8-1, $51-52 \mathrm{~cm}$. 
PLATE 3
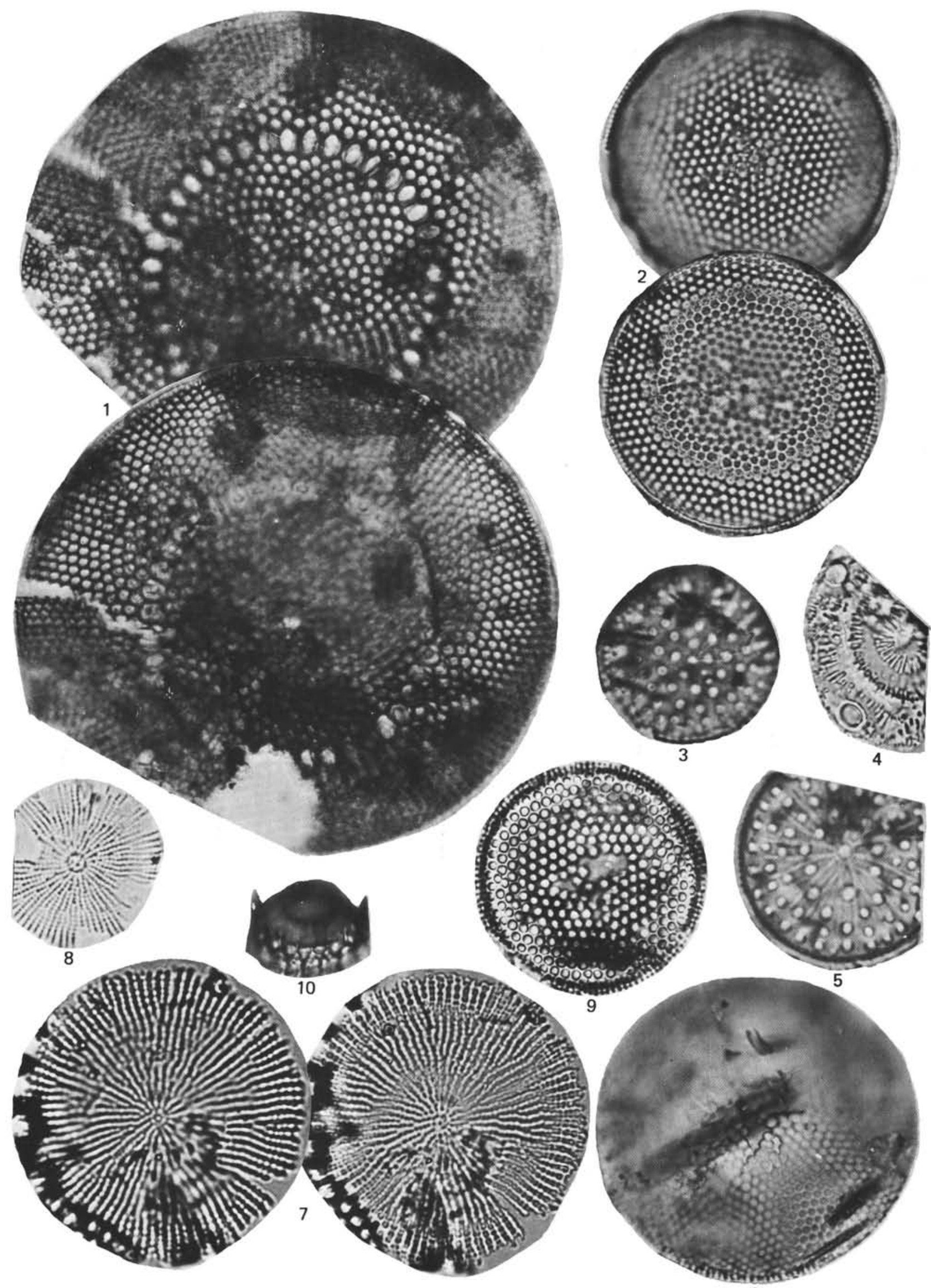
PLATE 4

Magnification $1500 \times$, except Figure 5, 750×

Figures $1-3$ Coscinodiscus demergitus $\mathrm{n}$. $\mathrm{sp}$.

Sample 354-12-1, 49-50 cm; Figure 1, Holotype.

Figure $4 \quad$ Coscinodiscus aff. tabularis (Grunow 1884).

Sample 356-6-3, 30-31 cm.

Figures 5-10 Coscinodiscus oligocenicus Jousé (1973).

5. Sample 354-12-3, 2-3 cm, 750x.

6. Sample $354-12-3,2-3 \mathrm{~cm}$.

7. Sample 354-12-1, $49-50 \mathrm{~cm}$.

8. Sample $354-12-3,2-3 \mathrm{~cm}$.

9. Sample $354-12-2,14-15 \mathrm{~cm}$.

10. Sample $354-12-1,49-50 \mathrm{~cm}$.

Figure $11 \quad$ Genus and species indet. 2.

Sample 356-8-2, 30-31 cm.

Figure 12 Melosira concentrica Schmidt (1887).

Sample 356-8-2, 30-31 cm. 
PLATE 4
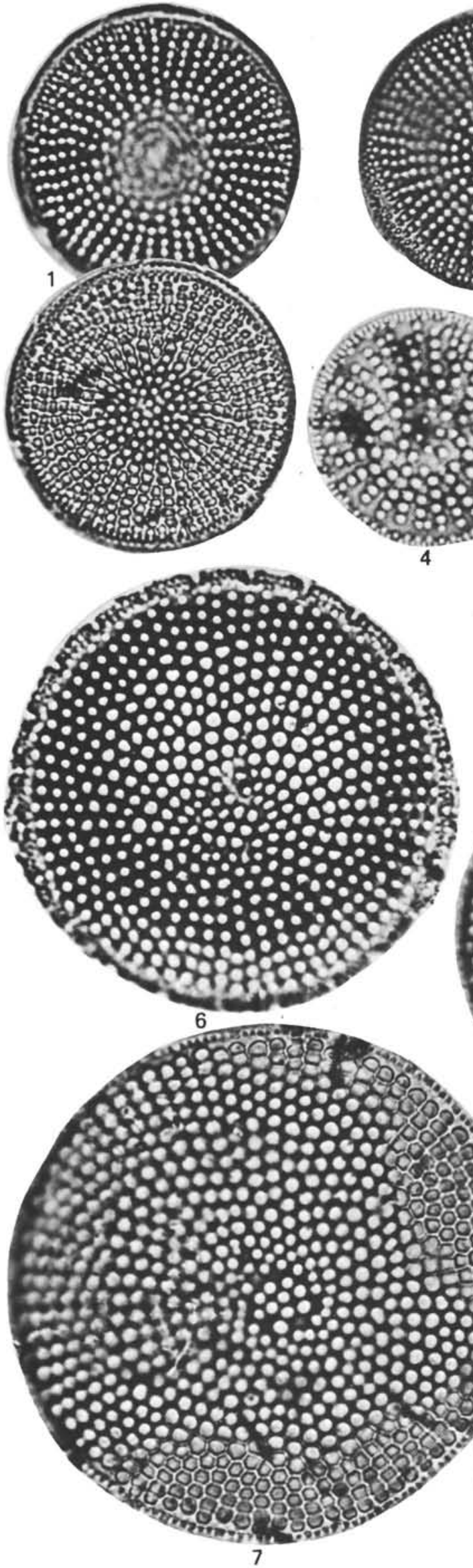

7
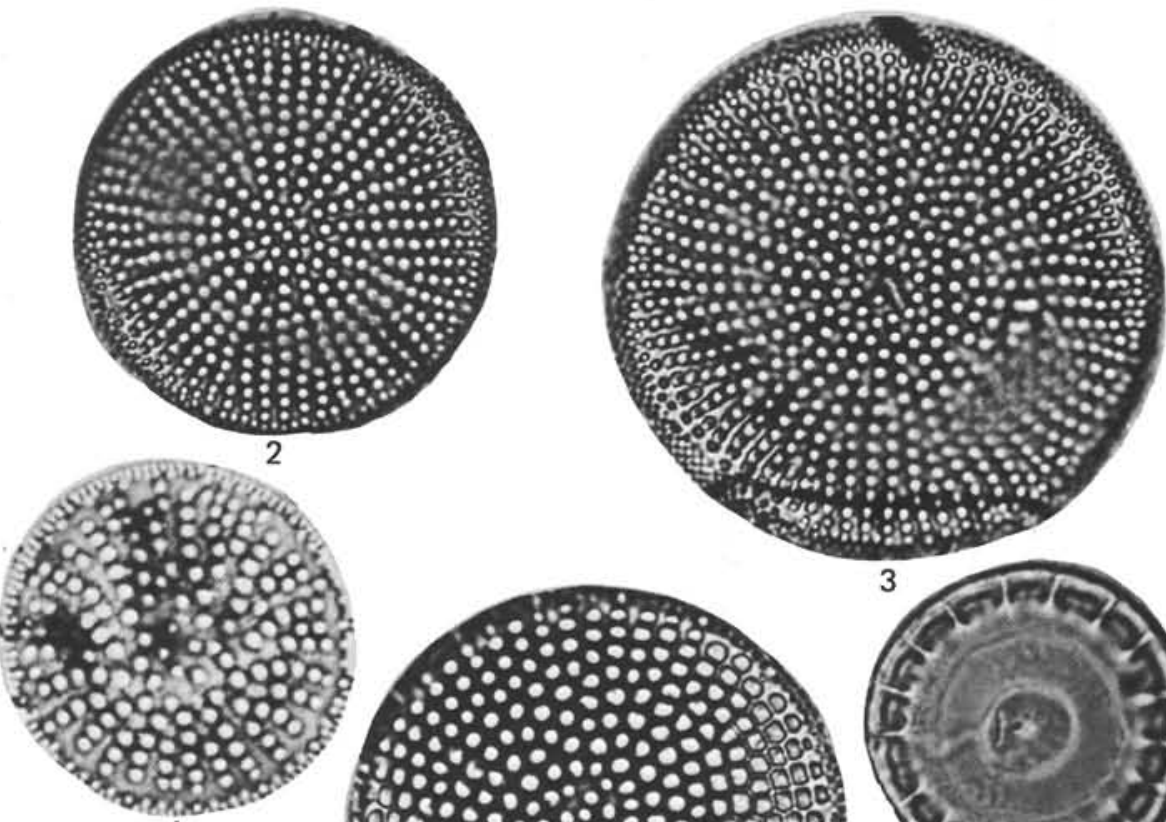

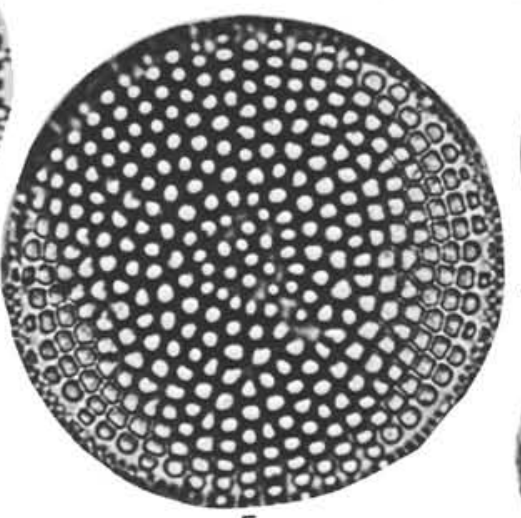

5
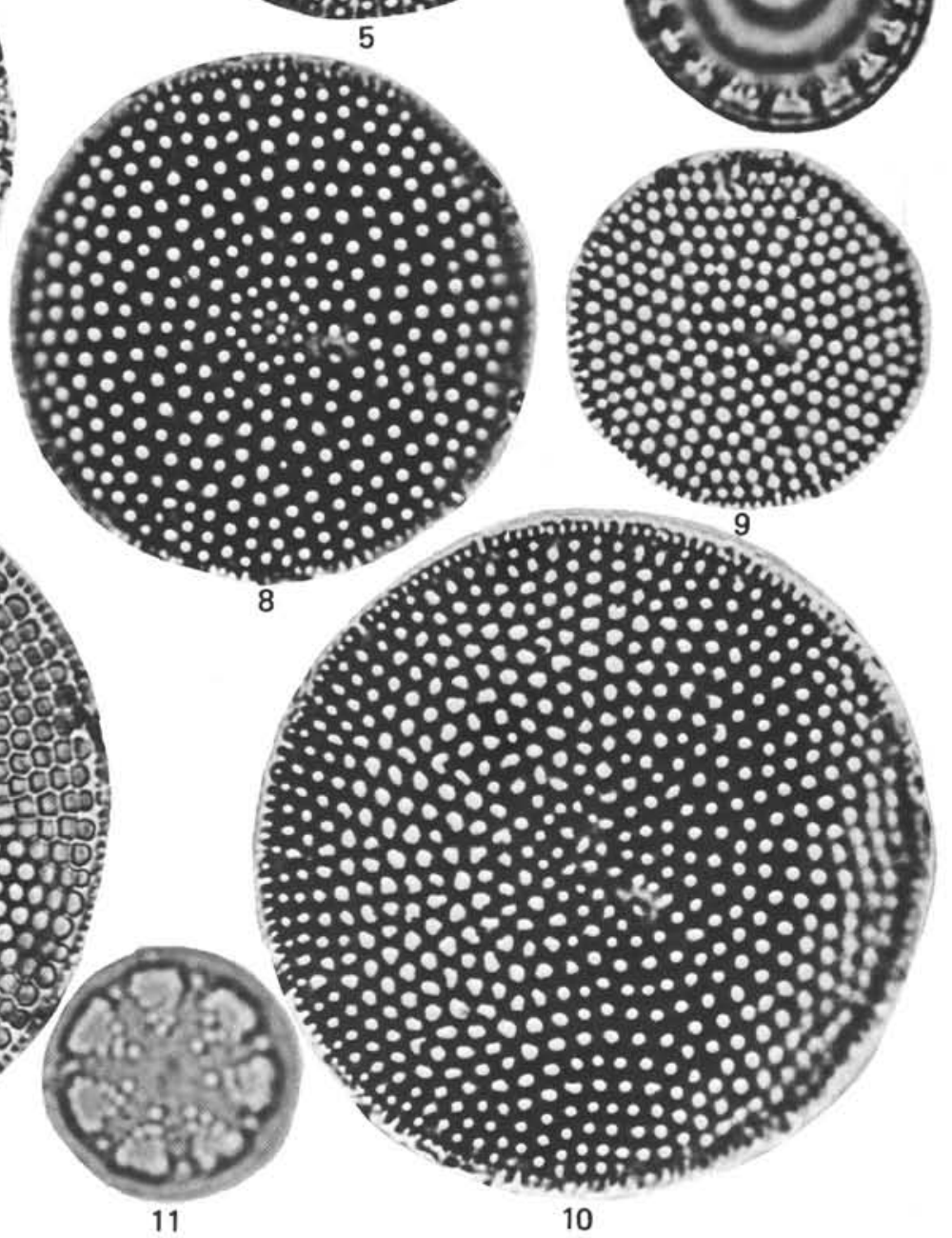


\section{PLATE 5}

Magnification $1500 \times$, except Figures 1,5, 1200×

Figure 1 Thalassiosira eccentrica (Ehr.) Cleve var. leasareolatus Kanaya in Kanaya and Koizumi (1966).

Sample 358-2-4, 30-31 cm, 1200×.

Figure 2 Coscinodiscus sp. 3.

Sample 354-12-3, 2-3 cm.

Figures 3,4 Coscinodiscus sp. 8 .

3. Sample 354-12-6, 40-41 cm.

4. Sample 354-12-5, $82-83 \mathrm{~cm}$.

Figure $5 \quad$ Genus and species indet.

Sample 354-12-1, 49-50 cm, 1200x.

Figure $6 \quad$ Coscinodiscus sp. 4.

Sample 356-9-2, 30-31 cm.

Figure 7 Coscinodiscus vetustissimus Pantocsek (1886).

Sample 354-12-3, 2-3 cm. 

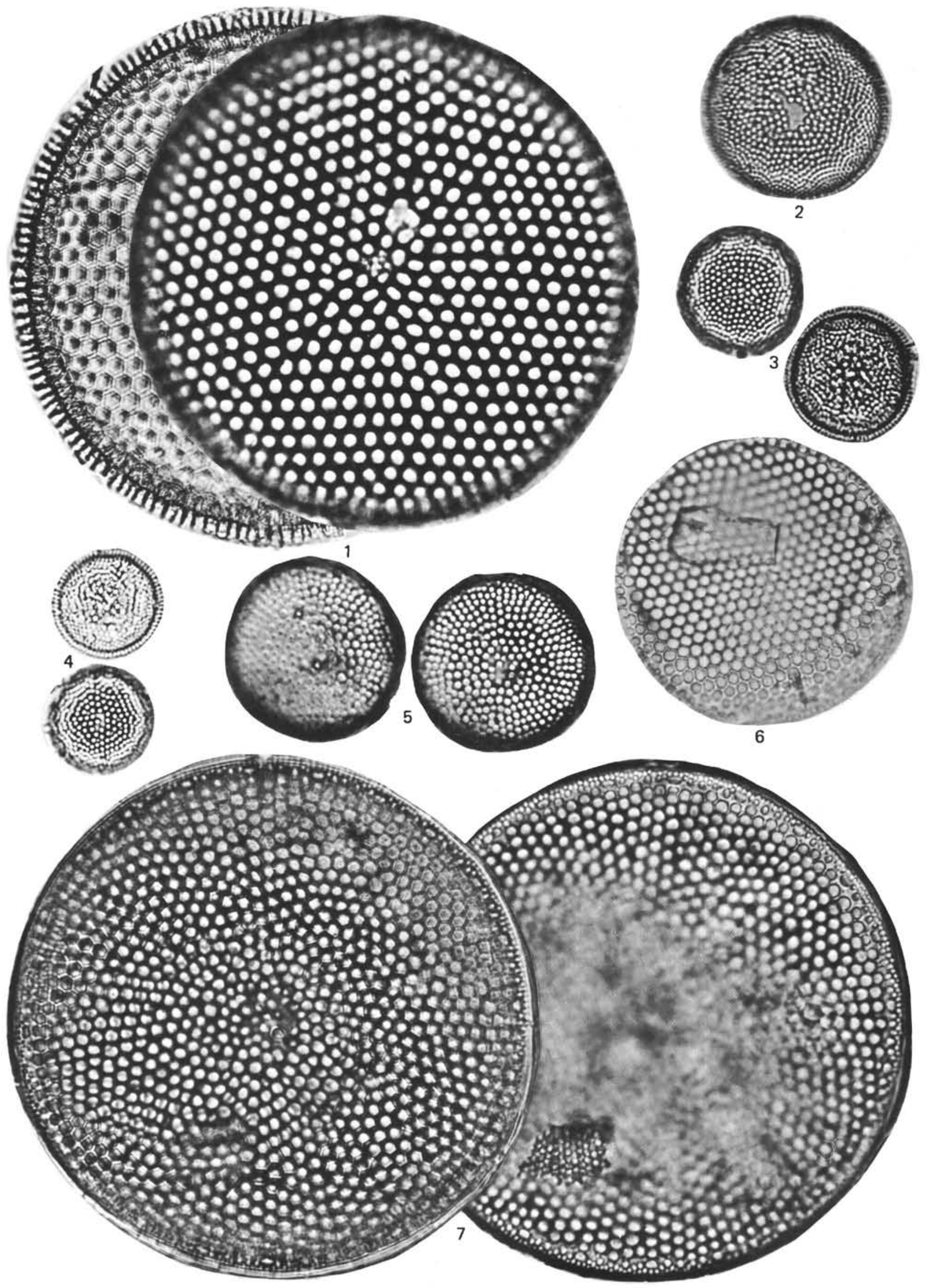


\section{PLATE 6}

Magnification 1500×, except Figures 1,8, 1000×: Figures 2,4, 750×

Figures 1,2 Coscinodiscus sp. 2.

Sample 354-12-3, 2-3 cm: Figure 1, 1000×: Figure 2, $750 \times$.

Figures 3,4 Stephanopyxis inordinata Hajós (1976). Sample 356-9-2, 30-31 cm; Figure 4, 750x.

Figure 5 Coscinodiscus gorbunowii? SheshukovaPoretzkaya (1964).

Sample 354-12-3, 2-3 cm.

Figure 6 Coscinodiscus sp. 5.

Sample 354-12-3, 2-3 cm.

Figures 7,8 Coscinodiscus sp. 1.

7. Sample $354-12-1,49-50 \mathrm{~cm}$.

8. Sample $354-12-2,14-15 \mathrm{~cm}, 1000 \times$.

Figure 9 Actinoptychus undulatus (Bail.) Ralfs in Pritchard (1861).

Sample 356-6-3, 30-31 cm.

Figures 10,11 Melosira sulcata (Ehr.) Kützing (1844).

10. Sample $356-8-1,51-52 \mathrm{~cm}$.

II. Sample 356-6-4, 30-31 cm. 
PLATE 6
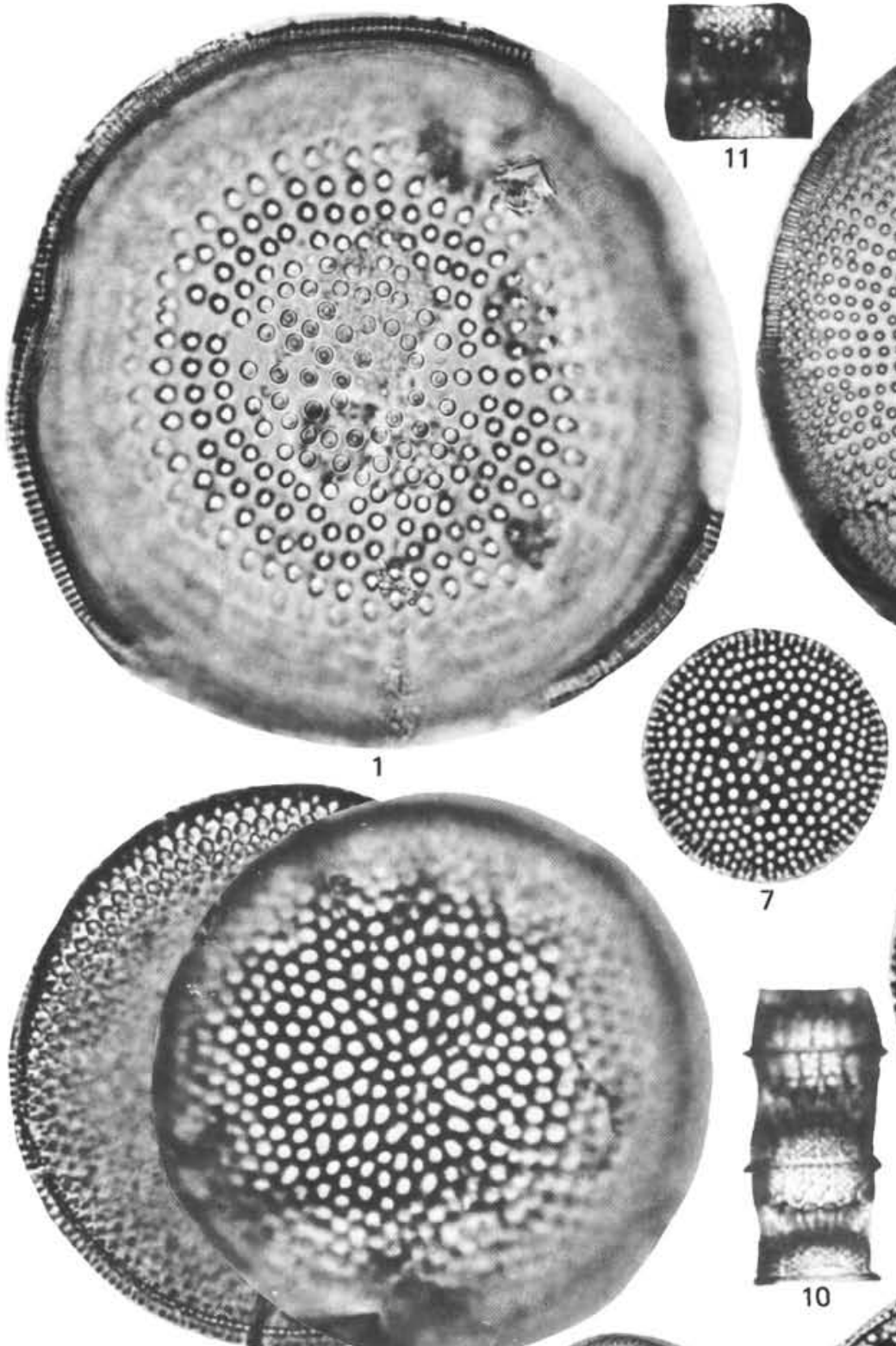

7
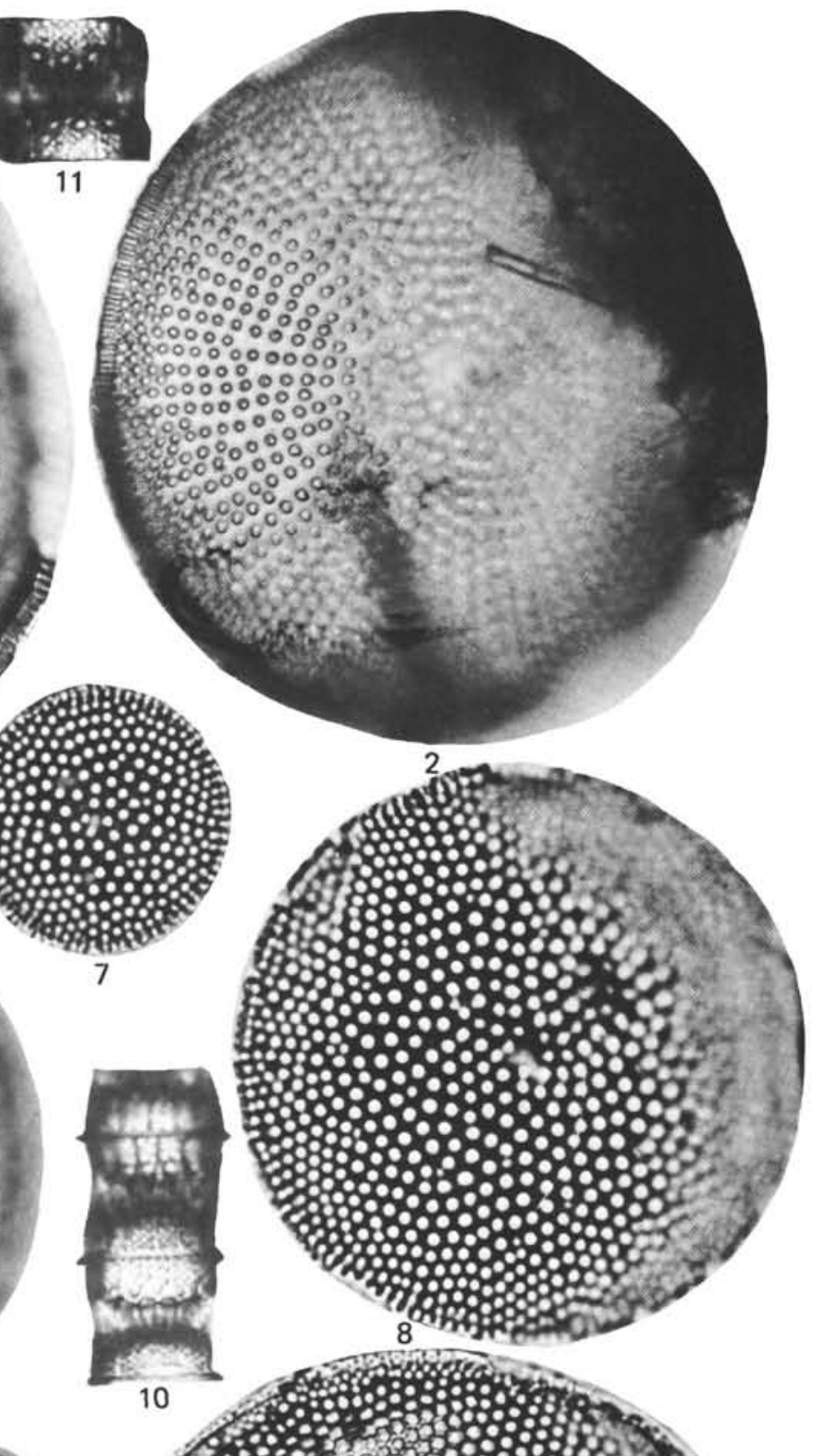

2000
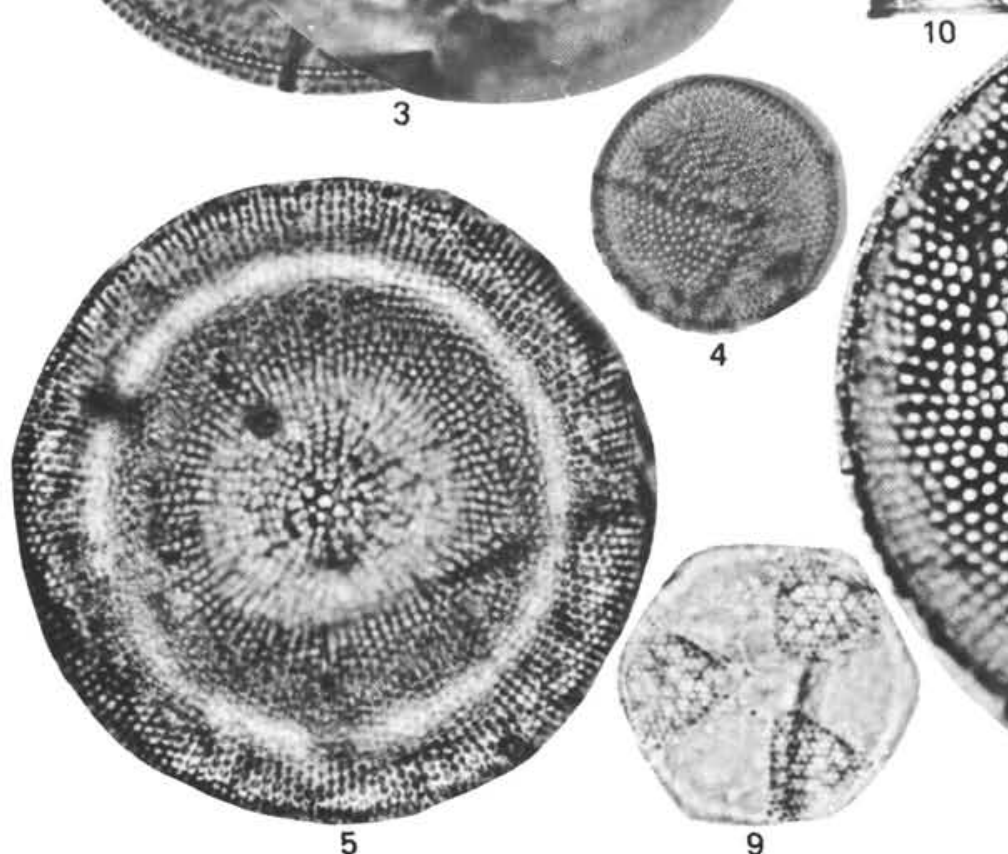

5
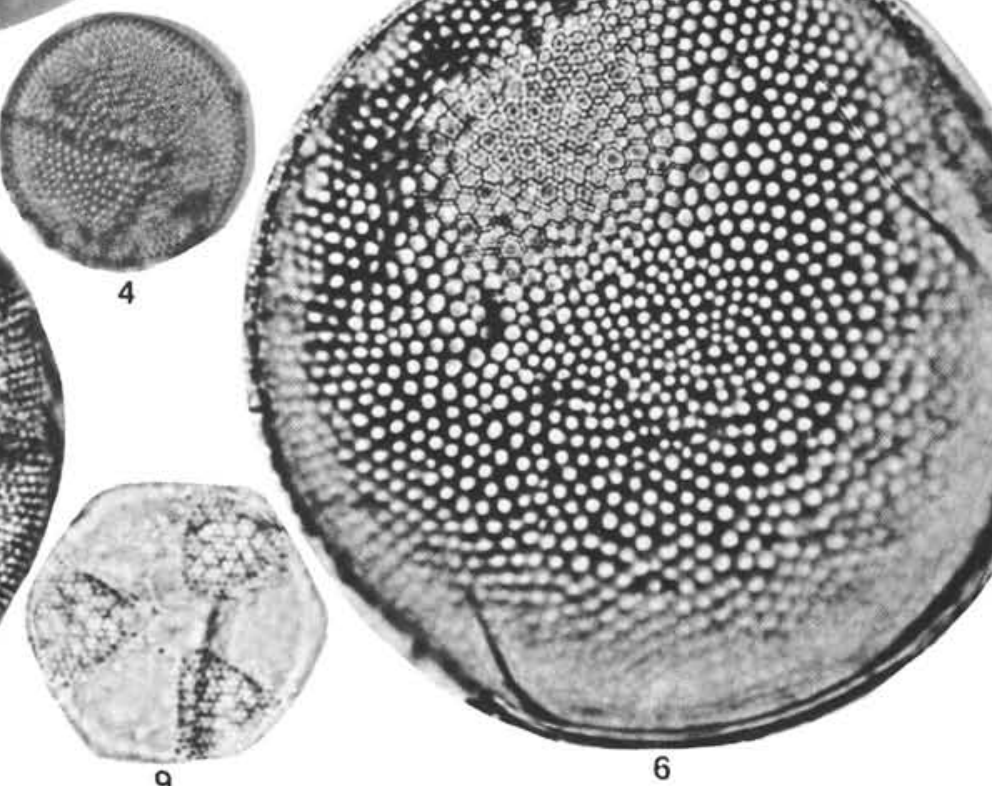

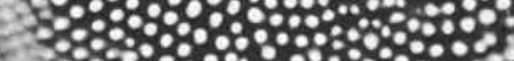
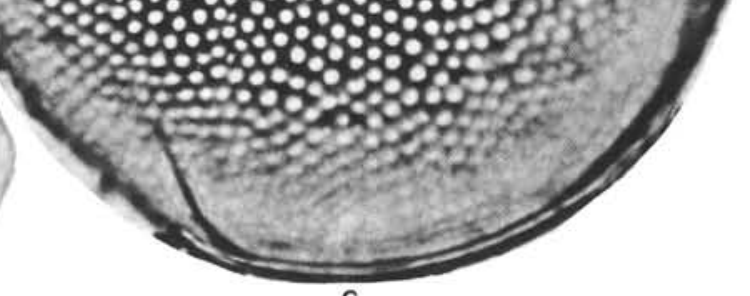

6 


\section{PLATE 7 \\ Magnification $1500 \times$, except Figure 3, $750 \times$}

Figures 1,2 Coscinodiscus heteroporus (working name).

1. Sample 356-7-6, 30-31 cm.

2. Sample $356-6-3,30-31 \mathrm{~cm}$.

Figure 3 Coscinodiscus apiculatus Ehrenberg (1844). Sample 354-12-6, 40-41 cm, 750X.

Figure 4 Coscinodiscus decrescens Grunow (1878).

Sample 354-12-1, 49-50 cm.

Figure $5 \quad$ Coscinodiscus sp.

Sample 356-8-1, 51-52 cm.

Figure 6 Coscinodiscus radiatus Ehrenberg (1839). Sample 354-12-1, 49-50 cm.

Figures 7-9 Melosira sp. 1.

7. Sample $354-12-1,49-50 \mathrm{~cm}$.

8. Sample 356-6-4, 30-31 cm.

9. Sample 356-6-6, 30-31 cm. 
PLATE 7

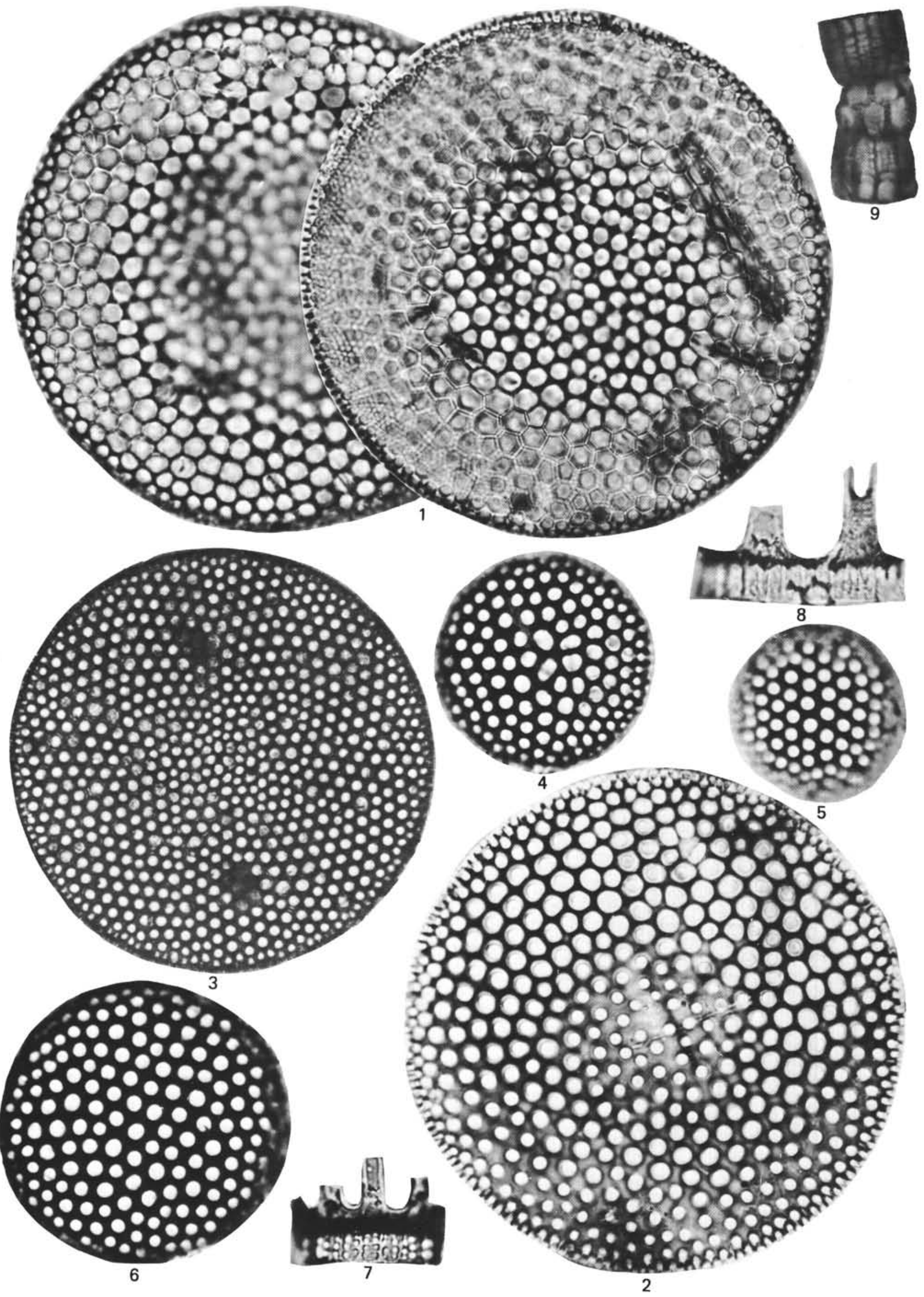




\section{PLATE 8}

Magnification 1500×, except Figure 3, 1200×

Figure 1 Coscinodiscus heteroporus (working name).

Sample 356-8-1, 51-52 cm.

Figure 2 Coscinodiscus aff. radiatus Ehrenberg (1839).

Sample 356-9-2, 30-31 cm.

Figure 3 Coscinodiscus marginatus Ehrenberg (1841).

Sample 354-12-3, 2-3 cm, $\times 1200$.

Figures 4-6 Coscinodiscus subtilis Ehrenberg (1841).

Sample 358-1-4, 90-91 cm.

Figure 7 Coscinodiscus marginatus Ehrenberg (1841).

Sample 354-12-1, 49-50 cm. 
PLATE 8

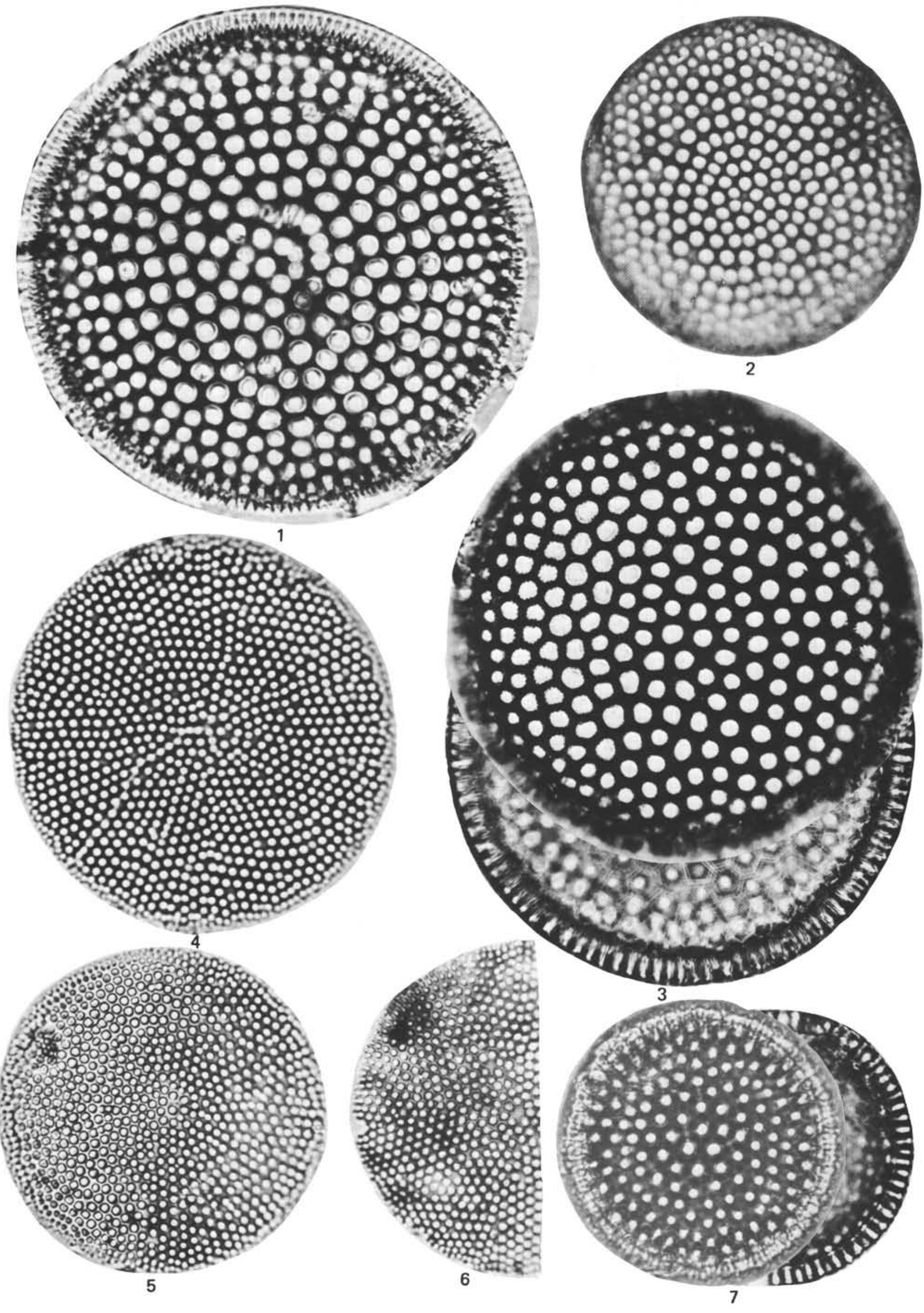




\section{PLATE 9}

Magnification 1500×, except Figures 3,8, 750×; Figure 6, 1200×

Figure 1 Coscinodiscus perforatus Ehrenberg (1844).

Sample $354-12-5,82-83 \mathrm{~cm}$; flat valve.

Figure 2 Pterotheca kittoniana var. kamtschatika Gaponov (1927).

Sample $356-7-2,30-31 \mathrm{~cm}$.

Figure $3 \quad$ Craspedodiscus aff. elegans Ehrenberg (1844).

Sample 356-8-2, 30-31 cm, 750X.

Figure $4 \quad$ Thalassiosira $\mathrm{sp}$.

Sample 356-9-2, 30-31 cm.

Figure 5 Pterotheca kittonia var. kamtschatika Gaponov (1927).

Sample 356-6-4, 30-31 cm.

Figure 6 Coscinodiscus perforatus Ehrenberg (1844).

Sample 354-12-5, 82-83 cm, 1200×; convex valve.

Figures 7,8 Coscinodiscus lentiginosus Janisch (1878) in Schmidt et al., (1874-).

Sample 358-1-2, 30-31 cm; Figure 8, 750×.

Figure 9 Coscinodiscus curvatulus Grunow (1878).

Sample 358-1-3, 30-31 cm. 


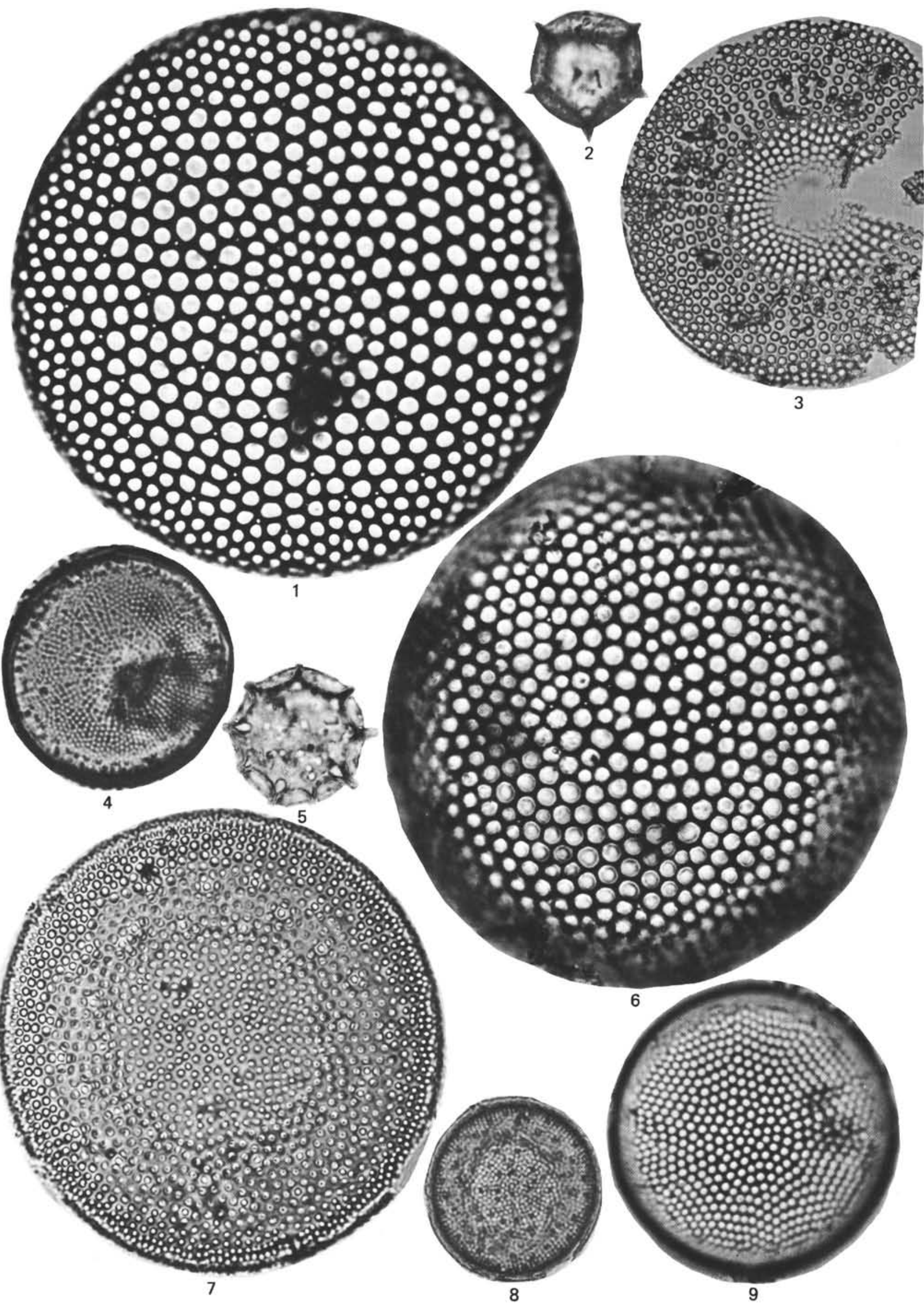


PLATE 10

Magnification 1500×, except Figures 11, 12, 750×;

Figures 13, 14, 1000×;

Figure $1 \quad$ Actinocyclus sp.

Sample 356-9-2, 30-31 cm.

Figures 2,3 Pseudopodosira bella Posnova and Gleser (1964).

2. Sample 356-6-4, 30-31 cm.

3. Sample $356-7-4,32-33 \mathrm{~cm}$.

Figures 4, 5 Pseudopodosira aspéra Jousé.

Sample 356-9-2, 30-31 cm.

Figures 6-8 Pseudopodosira bella Posnova and Gleser (1964).

6. Sample $356-7-6,30-31 \mathrm{~cm}$.

7. Sample 354-12-6, $40-41 \mathrm{~cm}$.

8. Sample 356-9-2, $30-31 \mathrm{~cm}$.

Figure $9 \quad$ Pseudopodosira sp. (badly preserved specimen). Sample 356-6-2, 30-31 cm.

Figure $10 \quad$ Coscinodiscus sellatus Jousé (1973).

Sample 354-12-1, 49-50 cm.

Figures 11,12 Coscinodiscus excavatus Grev. var. tuberosa no. var.

Sample $354-12-3,2-3 \mathrm{~cm}, 750 \times$.

Figures 13,14 Coscinodiscus excavatus Grev. var. semilunaris Grunow (1884) (same specimen).

Sample 354-12-1, 49-50 cm, 1000×. 
PLATE 10

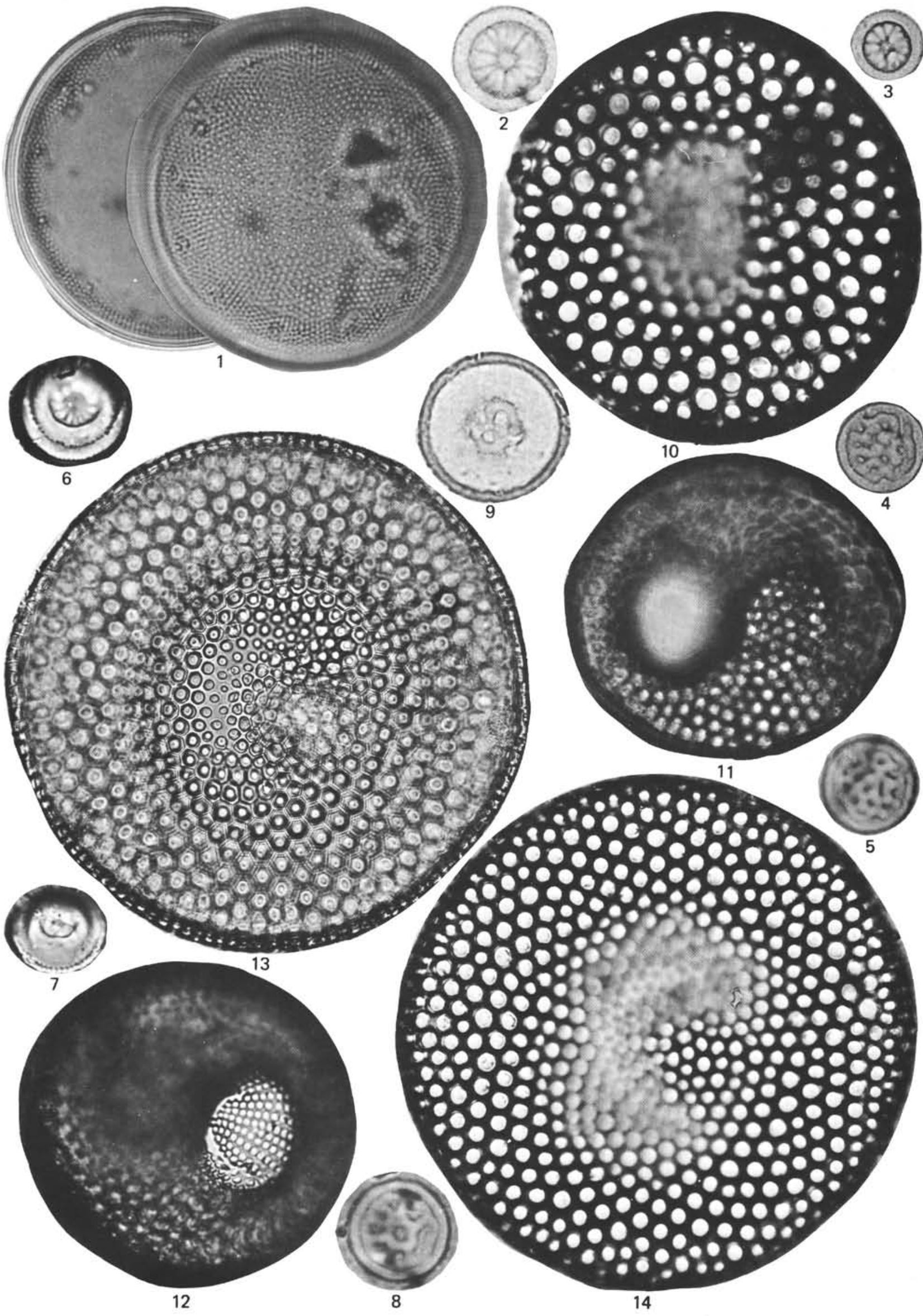




\section{PLATE 11}

Magnification 1500×, except Figures 1, 2, 4, 750×; Figure 3, 1000×

Figures 1-3 Coscinodiscus excavatus Grev. var. tuberosa n. var. 1. Sample 354-12-2, 14-15 cm, 750X.

2. Sample $354-12-5,82-83 \mathrm{~cm}, 750 \times$ (Holotype).

3. Sample $354-12-5,82-83 \mathrm{~cm}, 1000 \times$.

Figure 4 Coscinodiscus excavatus Grev. var. quadriocellata Grunow (1884).

Sample $354-12-5,82-83 \mathrm{~cm}, 750 \times$.

Figure $5 \quad$ Schimperiella antarctica Karsten (1905).

Sample 358-1-2, 30-31 cm.

Figures 6,7 Hyalodiscus elegans Strelnikova (1974).

6. Sample 356-7-2, 30-31 cm.

7. Sample $356-9-2,30-31 \mathrm{~cm}$. 
PLATE 11
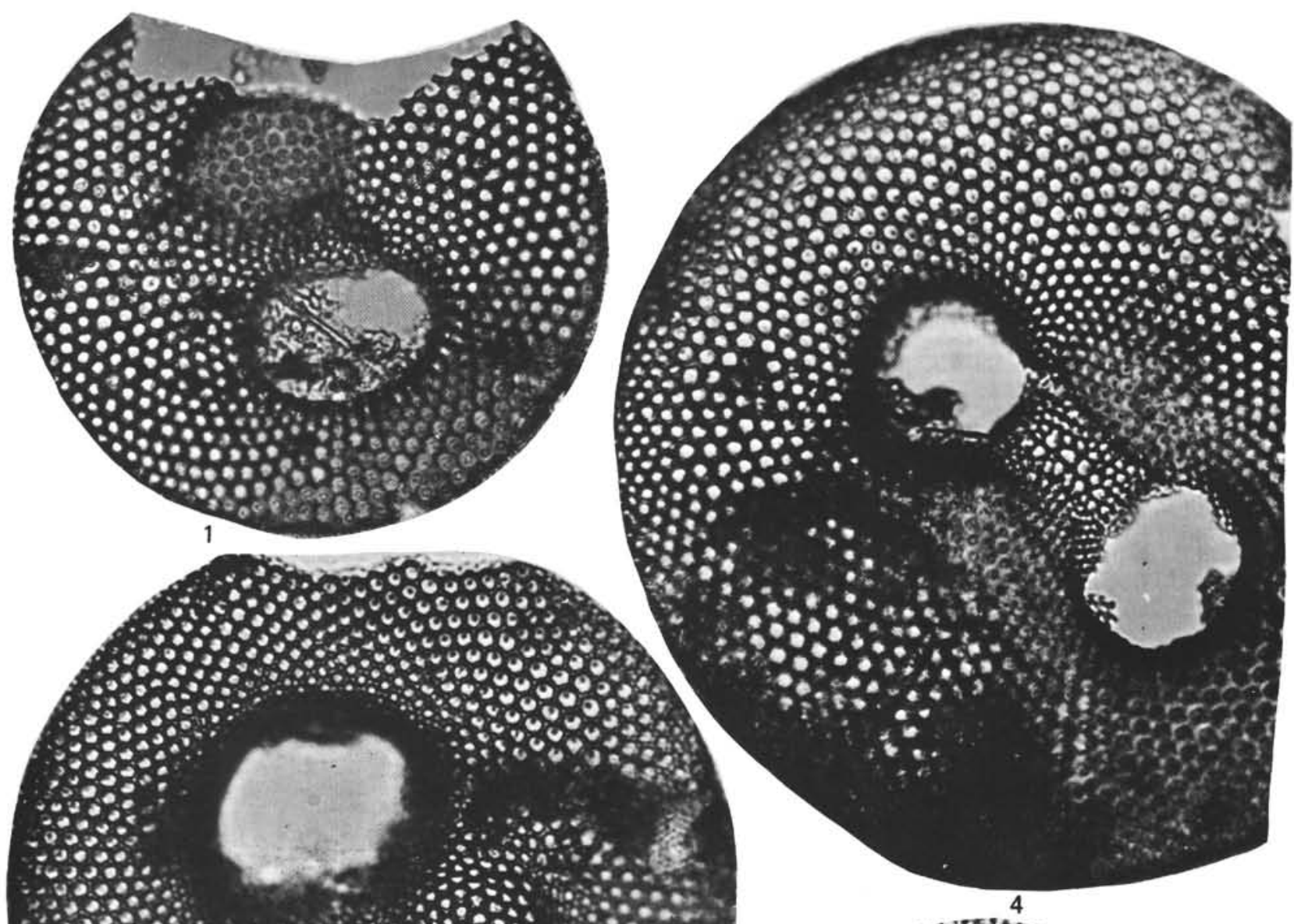
$+3: 3,3,0,400000 \%$

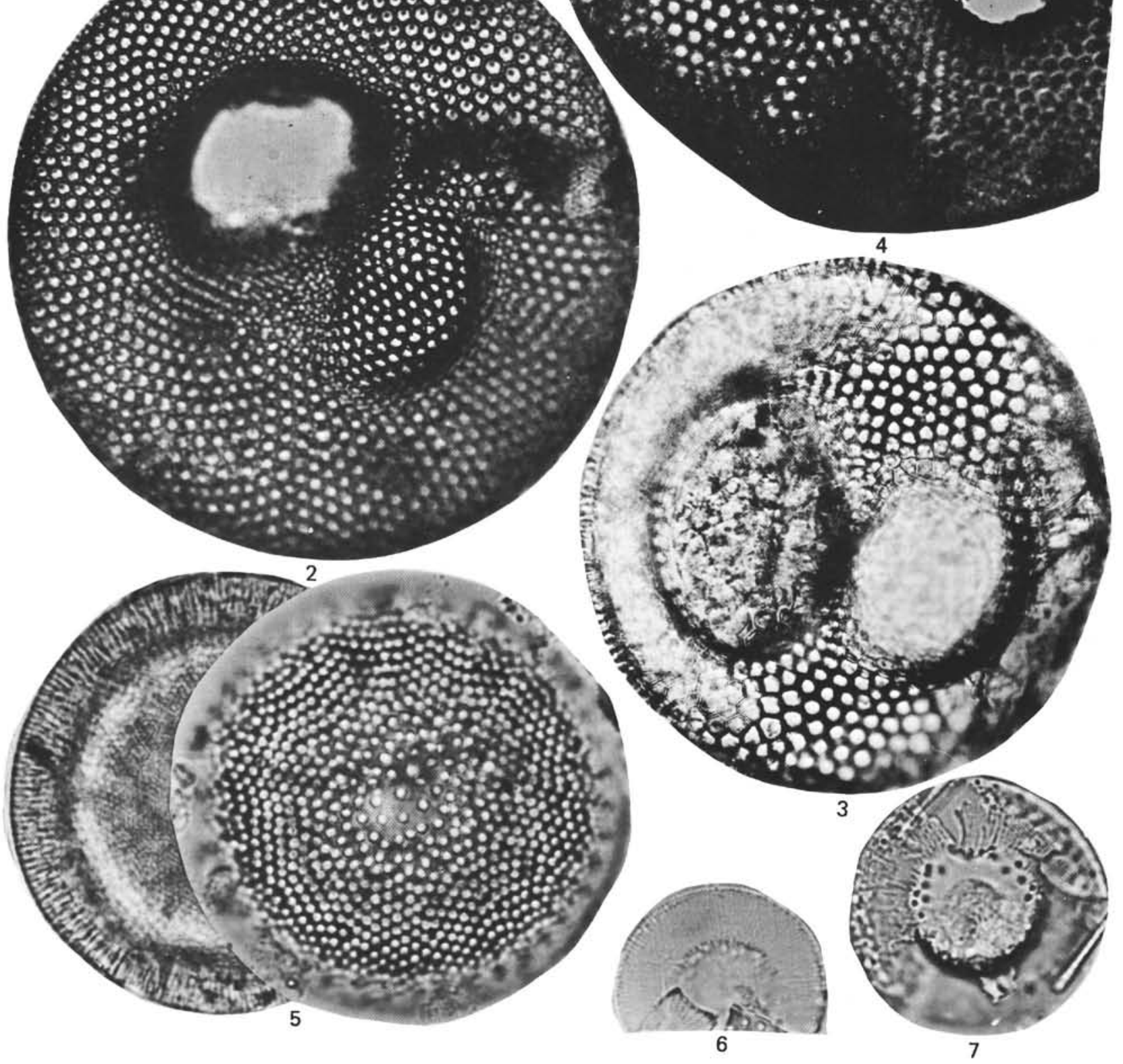




\section{PLATE 12}

Magnification 1500×, except Figure 1, 1200×; Figures 8, 9, 750×

Figure 1 Stephanopyxis superba (Grev.) Grunow (1884). Sample 356-6-6, 30-31 cm, 1200×.

Figure 2 Stephanopyxis punctata Jousé (1955). Sample 356-7-5, 30-31 cm.

Figure 3 Pterotheca $\mathrm{sp}$.

Sample $356-7-5,30-31 \mathrm{~cm}$.

Figure $4 \quad$ Pterotheca sp. 4 Schrader and Fenner (in press, b). Sample 356-9-2, 30-31 cm.

Figures 5,6 Pterotheca gracillima n. sp.

5. Sample 356-7-6, 30-31 cm (Holotype).

6. Sample 356-6-4, 30-31 cm.

Figure 7 Stephanopyxis turris (Grev. and Arn.) Ralfs in Pritchard (1861).

Sample 358-1-3, 30-31 cm.

Figures 8,9 Stephanopyxis turris (Grev. and Arn.) Ralfs in Pritchard (1861) var.

8. Sample $356-6-3,30-31 \mathrm{~cm}, 750 \times$.

9. Sample $356-6-6,30-31 \mathrm{~cm}, 750 \times$.

Figure $10 \quad$ Stephanopyxis grunowii Grove and Sturt (1888). Sample 356-6-2, 30-31 cm.

Figure 11 Stephanopyxis marginata Grunow (1884).

Sample 356-9-2, 30-31 cm.

Figure 12 Stephanopyxis corona (Ehr.) Grunow in Van Heurck (1880-1885).

Sample $356-7-3,30-31 \mathrm{~cm}$.

Figure 13 Stephanopyxis grunowii Grove and Sturt (1888). Sample 356-6-4, 30-31 cm. 
PLATE 12

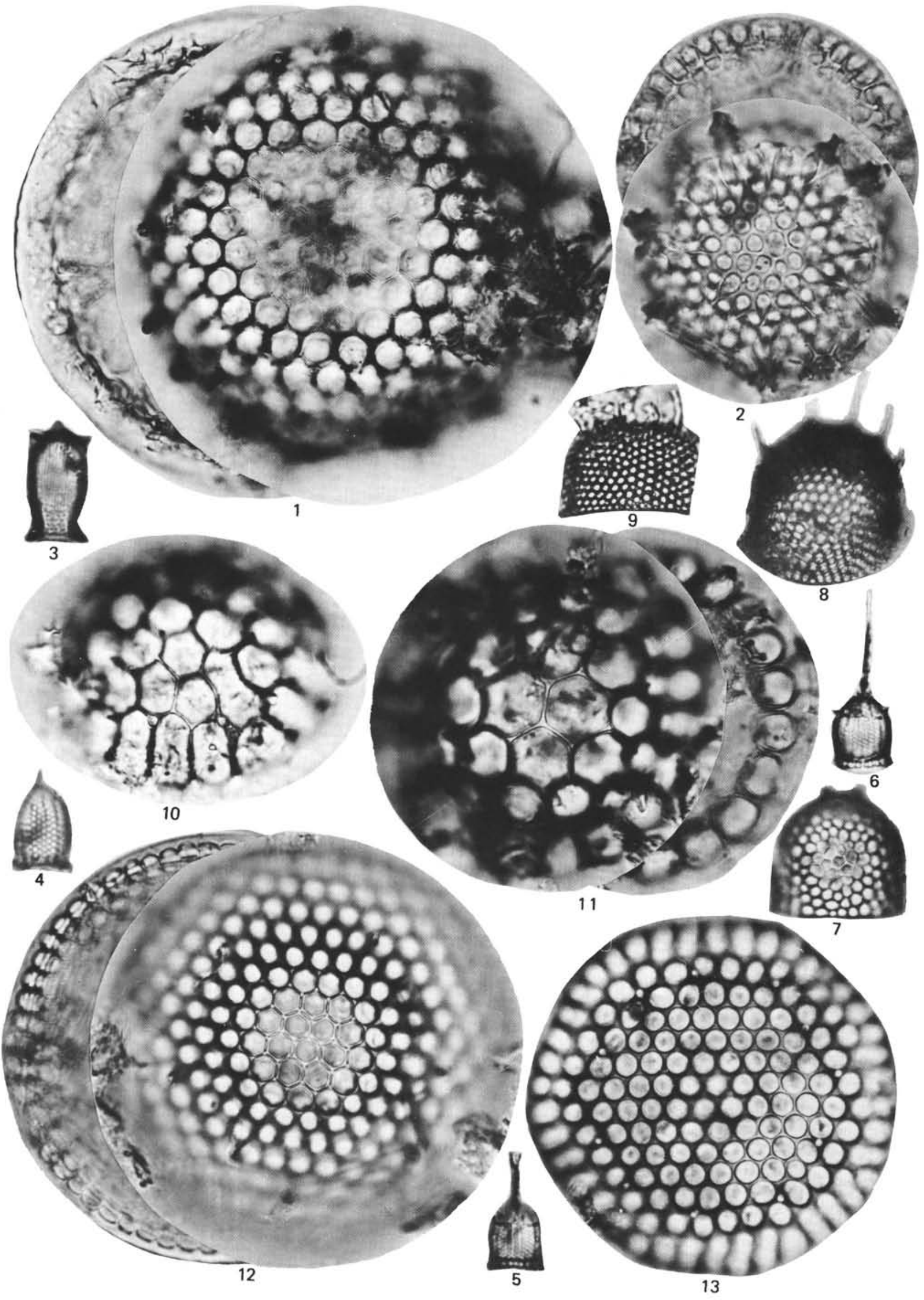




\section{PLATE 13}

Magnification $1500 \times$, except Figures 3, 4, 750×

Figures 1-5 Coscinodiscus superbus Hardmann in Rattray (1890).

1. Sample 354-12-1, 49-50 cm; convex valve.

2. Sample 354-12-2, 14-15 cm; convex valve.

3. Sample $354-12-2,14-15 \mathrm{~cm}, 750 \times$; convex valve.

4. Sample 354-12-3, 2-3 cm, 750×; convex valve.

5. Sample 354-12-1, 49-50 cm; convex valve.

Figure 6 Melosira sulcata (Ehr.) Kützing (1844).

Sample 356-9-2, 30-31 cm.

Figures 7-9 Stephanogonia horridus Schrader in Schrader and Fenner (in press, b).

7. Sample 356-9-2, 30-31 cm.

8. Sample 356-6-2, 30-31 cm.

9. Sample $356-6-2,30-31 \mathrm{~cm}$. 
PLATE 13

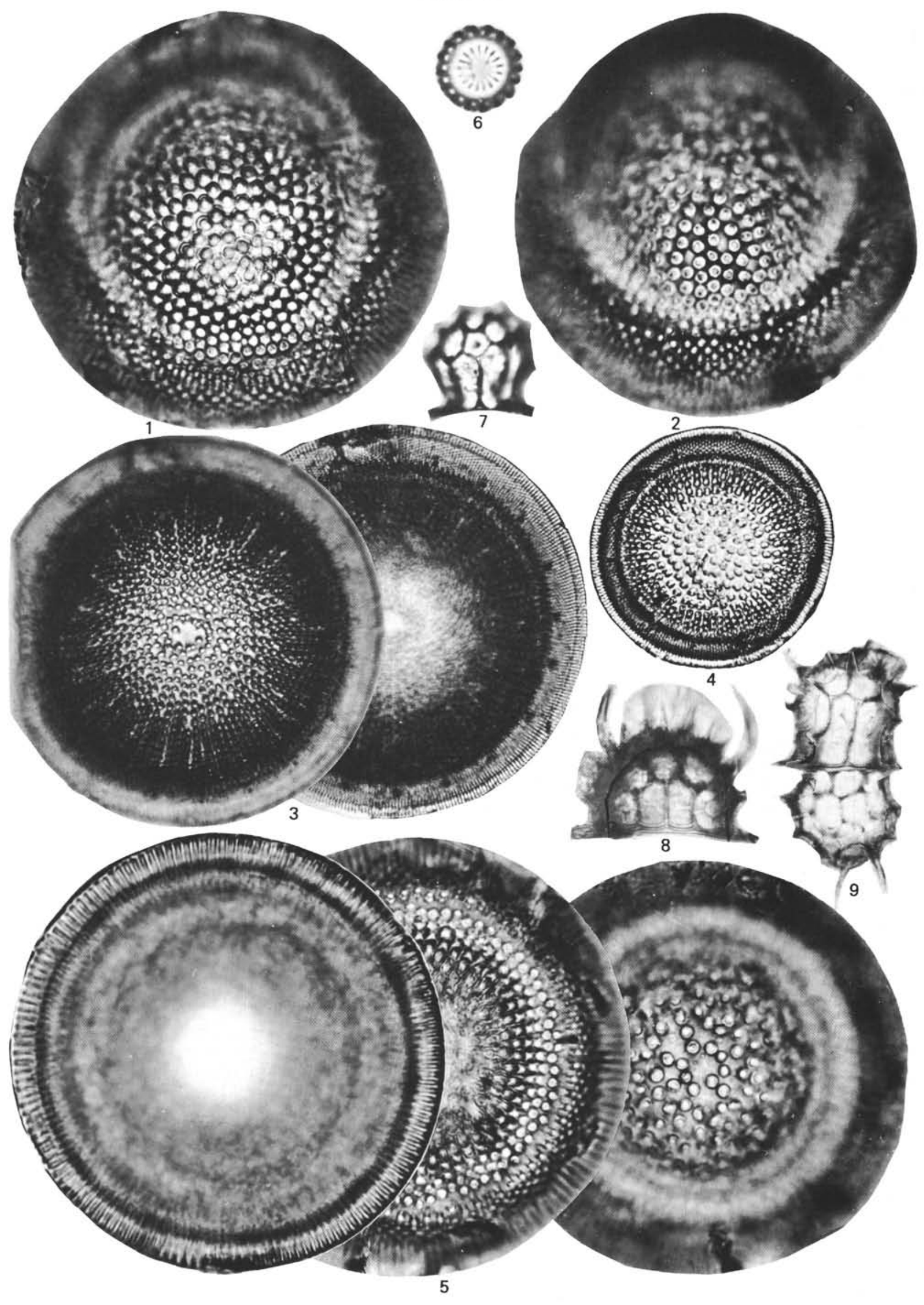


PLATE 14

Magnification 1500×, except Figure 4, 1200X

Figures 1-4 Coscinodiscus superbus Hardmann in Rattray (1890).

1. Sample 354-12-1, 49-50 cm; concave valve.

2. Sample 354-12-3, 2-3 cm; concave valve.

3. Sample 354-12-1, 49-50 cm; concave valve.

4. Sample 354-12-1, 49-50 cm, 1200X; convex valve.

Figure $5 \quad$ Hyalodiscus elegans Strelnikova (1974).

Sample 356-9-2, 30-31 cm; badly preserved specimen.

Figure $6 \quad$ Melosira westii W. Smith (1856),

Sample $356-7-6,30-31 \mathrm{~cm}$; badly preserved specimen.

Figure $7 \quad$ Melosira sulcata (Ehr.) Kützing (1844)

Sample $356-7-2,30-31 \mathrm{~cm}$; badly preserved specimen.

Figure $8 \quad$ Skelettonema stylifera Brun (1891).

Sample 356-6-4, 30-31 cm.

Figure 9 Pseudopyxilla dubia (Grun.) Forti (1909).

Sample 356-6-6, 30-31 cm. 
PLATE 14

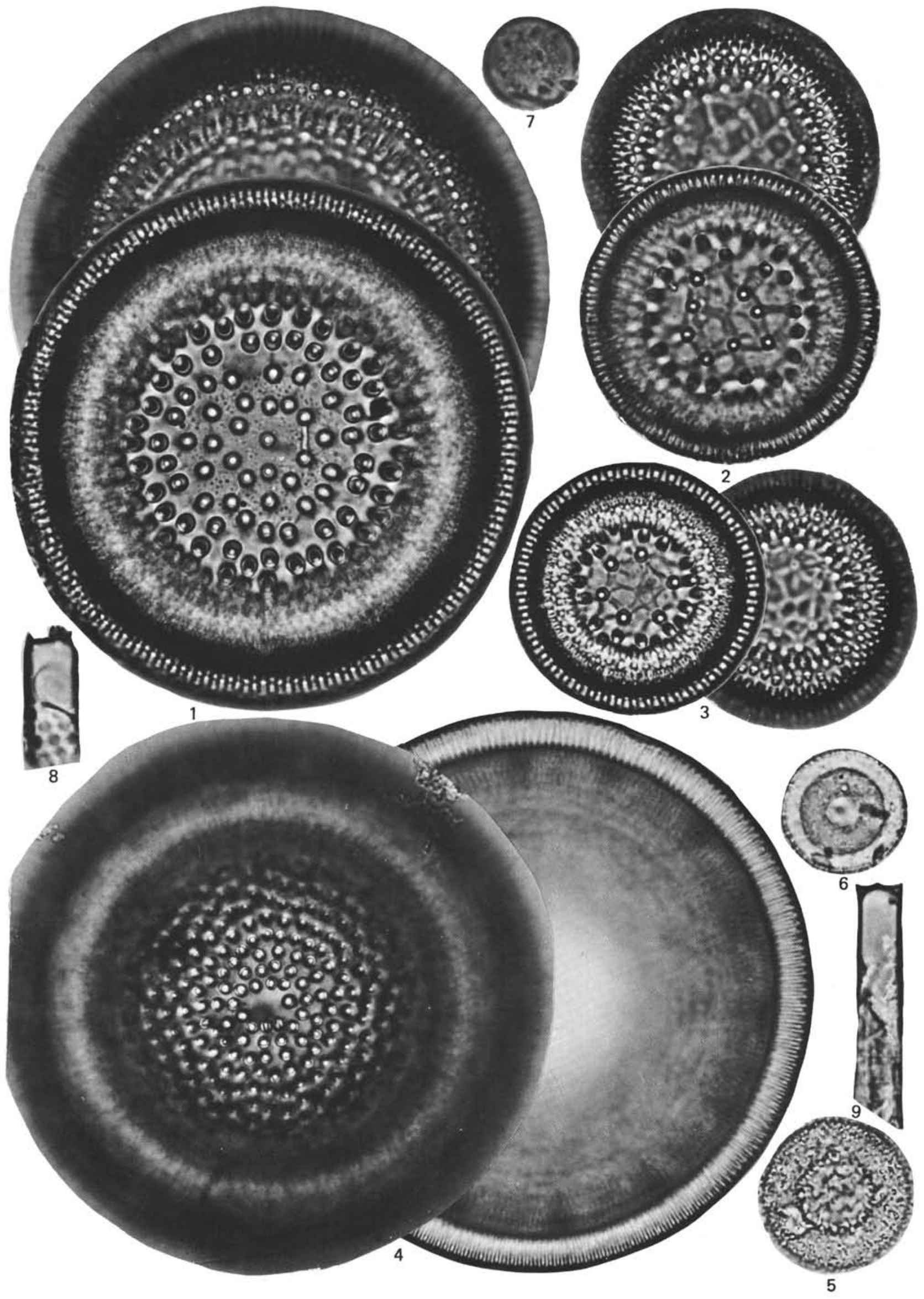


PLATE 15

Magnification $1500 \times$, except Figure 5, 750×

Figure 1 Actinoptychus splendens (Shadb.) Ralfs in Pritchard (1861).

Sample $354-12-5,82-83 \mathrm{~cm}$.

Figures 2, 3 Glyphodiscus dubiosus Hanna and Brigger (1964).

2. Sample $356-6-5,30-31 \mathrm{~cm}$.

3. Sample $354-12-5,82-83 \mathrm{~cm}$.

Figure 4 Actinocyclus ingens Rattray (1890).

Sample 358-2-4, 30-31 cm.

Figure 5 Aulacodiscus sp. 1.

Sample 356-9-2, 30-31 cm, 750×.

Figure $6 \quad$ Stephanogonia reticulata Forti (1913).

Sample 356-9-2, 30-31 cm.

Figures 7,8 Podosira polita Hanna and Grant (1926).

Sample 354-12-3, 2-3 cm.

Figure $9 \quad$ Auliscus sp.

Sample 356-7-3, 30-31 cm.

Figure 10 Stephanogonia reticulata Forti (1913), aberrant form.

Sample 356-9-2, 30-31 cm.

Figure $11 \quad$ Melosira westii W. Smith (1856).

Sample $356-6-4,30-31 \mathrm{~cm}$; badly preserved specimen. 
PLATE 15

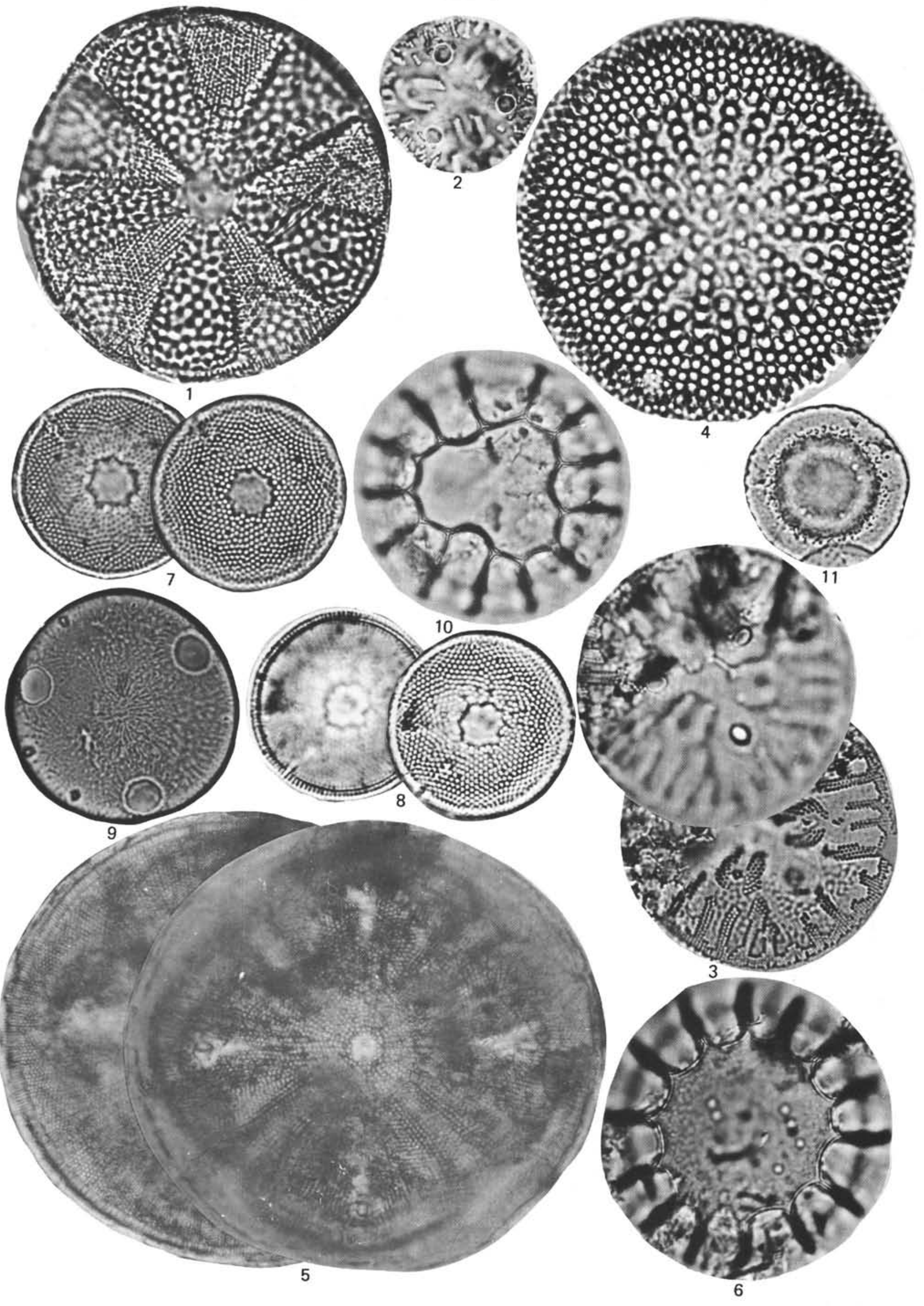




\section{PLATE 16 \\ Magnification 1500X}

Figures 1,2 Actinoptychus intermedius A. Schmidt (1886).

1. Sample 356-6-4, 30-31 cm.

2. Sample $356-7-2,30-31 \mathrm{~cm}$.

Figure 3 Rylandsia sp.

Sample 354-12-1, 49-50 cm.

Figure $4 \quad$ Rylandsia biradiata Greville (1861).

Sample 356-9-2, 30-31 cm.

Figure 5 Asterolampra sp.

Sample 356-6-4, 30-31 cm.

Figure 6 Asterolampra acutiloba Forti in Tempère and Peragallo (1912).

Sample 358-2-4, 30-31 cm.

Figures 7-12 Melosira architecturalis (Brun) (1892).

7. Sample $356-9-2,30-31 \mathrm{~cm}$.

8. Sample 356-6-4, 30-31 cm.

9. Sample 356-9-2, 30-31 cm.

10. Sample $356-6-4,30-31 \mathrm{~cm}$.

11. Sample $356-6-2,30-31 \mathrm{~cm}$.

12. Sample $356-6-2,30-31 \mathrm{~cm}$.

Figures 13-17 Melosira sulcata (Ehr.) Kützing (1844).

13. Sample 356-9-2, $30-31 \mathrm{~cm}$.

14. Sample $356-6-2,30-31 \mathrm{~cm}$.

15. Sample $358-2-4,30-31 \mathrm{~cm}$.

16. Sample $356-9-2,30-31 \mathrm{~cm}$.

17. Sample $356-6-4,30-31 \mathrm{~cm}$.

Figure $18 \quad$ Melosira subornata A. Schmidt (1892).

Sample 356-6-2, 30-31 cm.

Figure 19 Liostephania stage of an unknown species (Hyalodiscus?).

Sample 356-7-6, 30-31 cm. 


\section{PLATE 16}
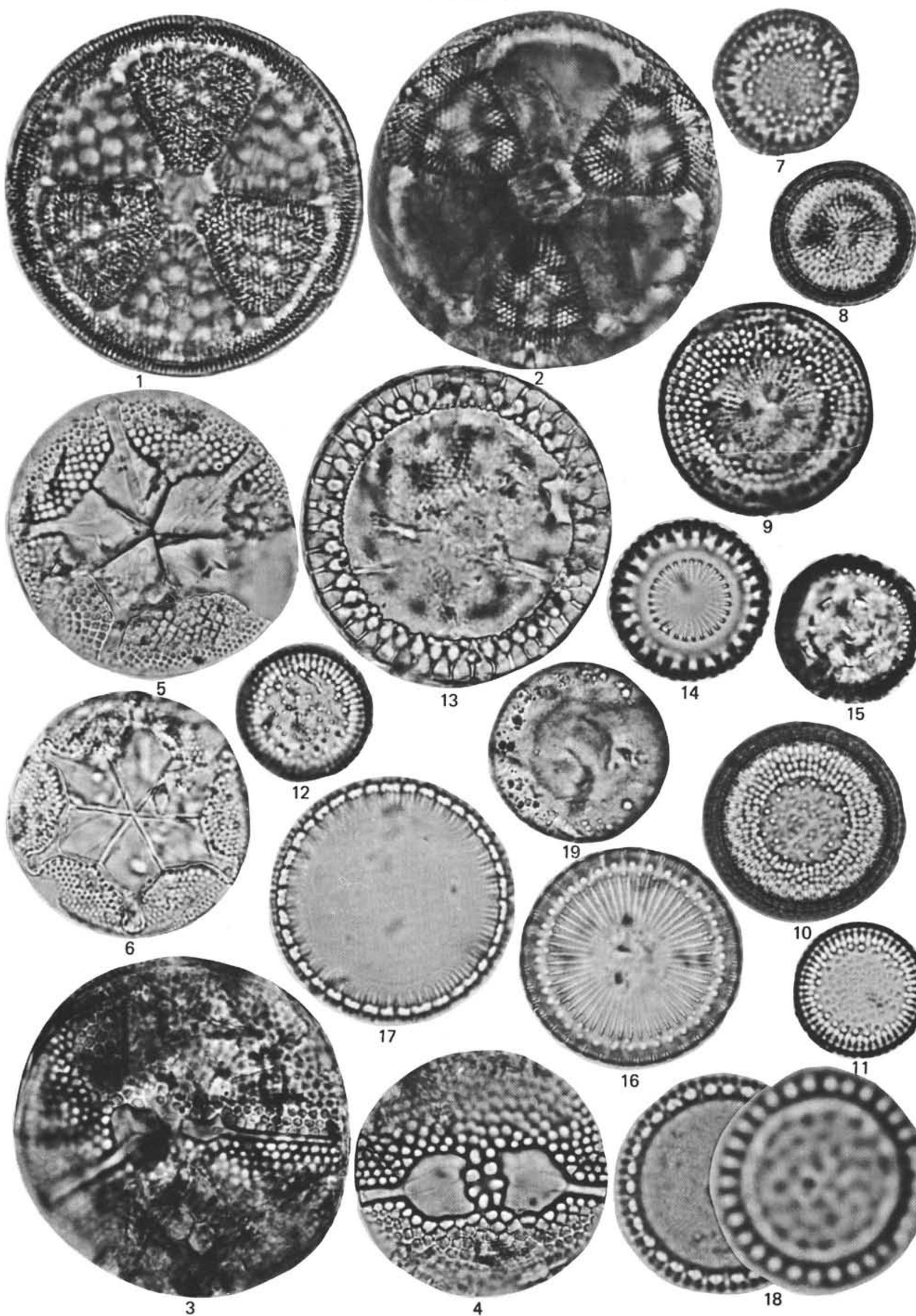

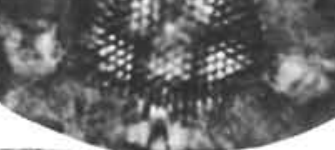
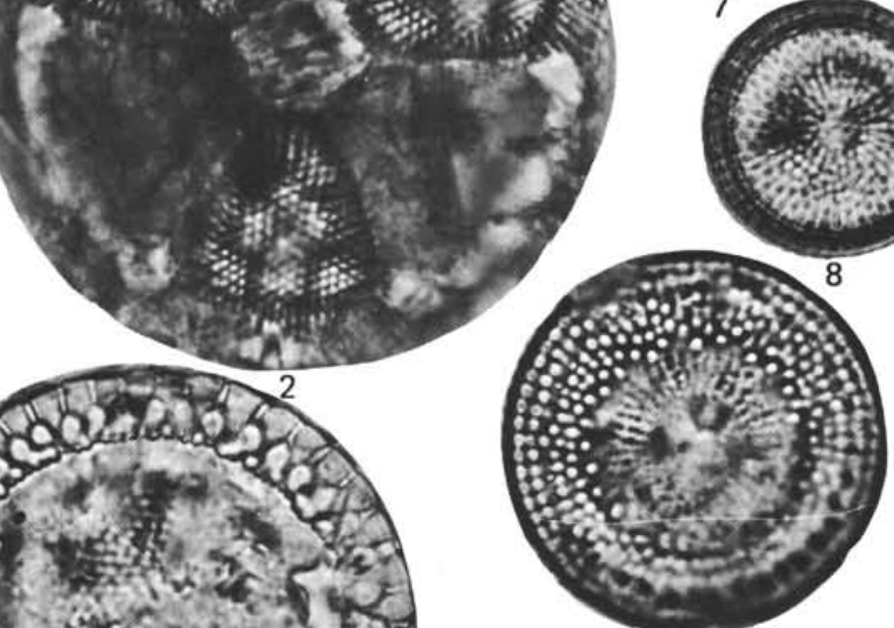


\section{PLATE 17}

Magnification 1500×, except Figure 7, 1000×

Figures 1-6 Pseudopyxilla dubia (Grunow) Forti (1909).

1. Sample 356-6-6, 30-31 cm.

2. Sample $356-9-2,30-31 \mathrm{~cm}$.

3. Sample $356-7-2,30-31 \mathrm{~cm}$.

4. Sample 356-7-2, 30-31 cm.

5. Sample 356-6-6, 30-31 cm.

6. Sample $356-9-2,30-31 \mathrm{~cm}$.

Figure $7 \quad$ Pseudopyxilla sp.

Sample 356-6-2, 30-31 cm, 1000×.

Figures 8-21 Pterotheca aculeifera Grunow (1880).

8. Sample $356-7-5,30-31 \mathrm{~cm}$.

9. Sample $356-9-2,30-31 \mathrm{~cm}$.

10. Sample $356-8-1,51-52 \mathrm{~cm}$.

11. Sample $356-7-4,32-33 \mathrm{~cm}$.

12. Sample $356-7-4,32-33 \mathrm{~cm}$.

13. Sample $356-7-4,32-33 \mathrm{~cm}$.

14. Sample $356-9-2,30-31 \mathrm{~cm}$.

15. Sample 356-6-6, 30-31 cm.

16. Sample 356-9-2, 30-31 cm.

17. Sample $356-7-5,30-31 \mathrm{~cm}$.

18. Sample $356-7-4,32-33 \mathrm{~cm}$.

19. Sample $356-7-2,30-31 \mathrm{~cm}$.

20. Sample $356-6-4,30-31 \mathrm{~cm}$.

21. Sample 356-8-1, $51-52 \mathrm{~cm}$.

Figure 22 Pterotheca uralica Jousé (1949). Sample $356-7-2,30-31 \mathrm{~cm}$.

Figure 23 Pterotheca $\mathrm{sp} .1$.

Sample $356-5-1,30-31 \mathrm{~cm}$.

Figure 24 Asteromphalus aff. robustus Castracane (1875).

Sample 358-1-4, 90-91 cm. 
PLATE 17

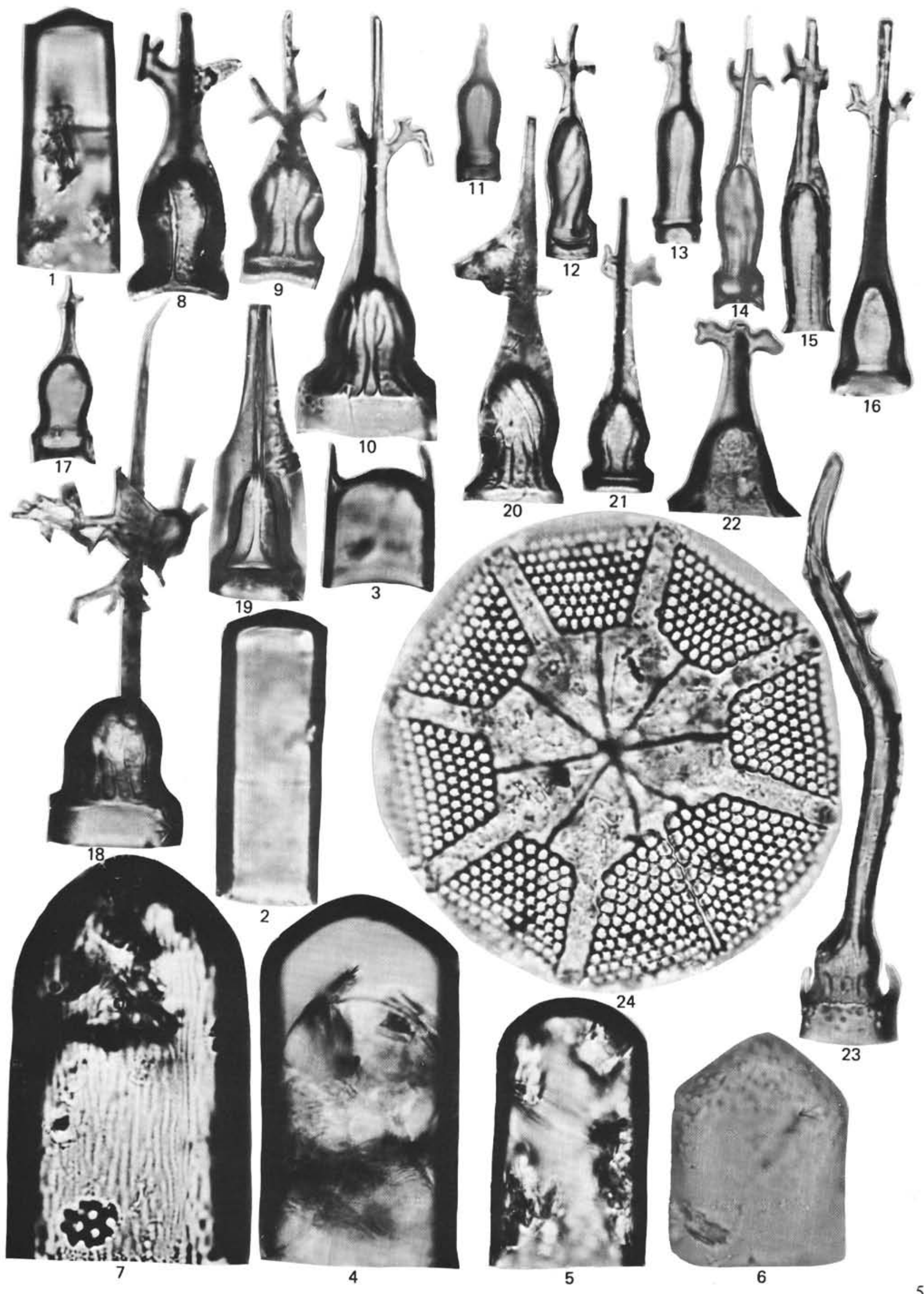


PLATE 18

Magnification 1500×, except Figure 9, 1200×

Figure 1 Liostephania stage of Coscinodiscus tabularis. Sample 356-5-5, 30-31 cm.

Figure 2 Liostephania stage of unknown species. Sample 356-7-3, 30-31 cm.

Figure 3 Asterolampra aff. grevillei (Wallich) Greville (1860).

Sample 354-12-1, 49-50 cm.

Figure $4 \quad$ Liostephania stage of Asterolampra spp. Sample 356-6-4, 30-31 cm.

Figure $5 \quad$ Liostephania stage of Asteromphalus spp. Sample 356-6-2, 30-31 cm.

Figure $6 \quad$ Genus and species indet. Sample 356-6-2, 30-31 cm.

Figure $7 \quad$ Liostephania stage unknown species. Sample 356-9-2, 30-31 cm.

Figure $8 \quad$ Liostephania stage of Asterolampra spp. Sample 356-6-3, 30-31 cm.

Figure 9 Pseudopodosira elegans? Sheshukova-Poretzkaya (1964).

Sample $356-6-3,30-31 \mathrm{~cm}, 1200 \times$.

Figure $10 \quad$ Liostephania stage of Asteromphalus spp. Sample 356-6-4, 30-31 cm.

Figure $11 \quad$ Melosira westii W. Smith (1856). Sample 356-6-2, 30-31 cm.

Figure 12 Liostephania stage of Asterolampra spp. Sample 356-6-5, 30-31 cm.

Figure 13 Liostephania stage of Asteromphalus spp. Sample 356-6-5, 30-31 cm. 
PLATE 18

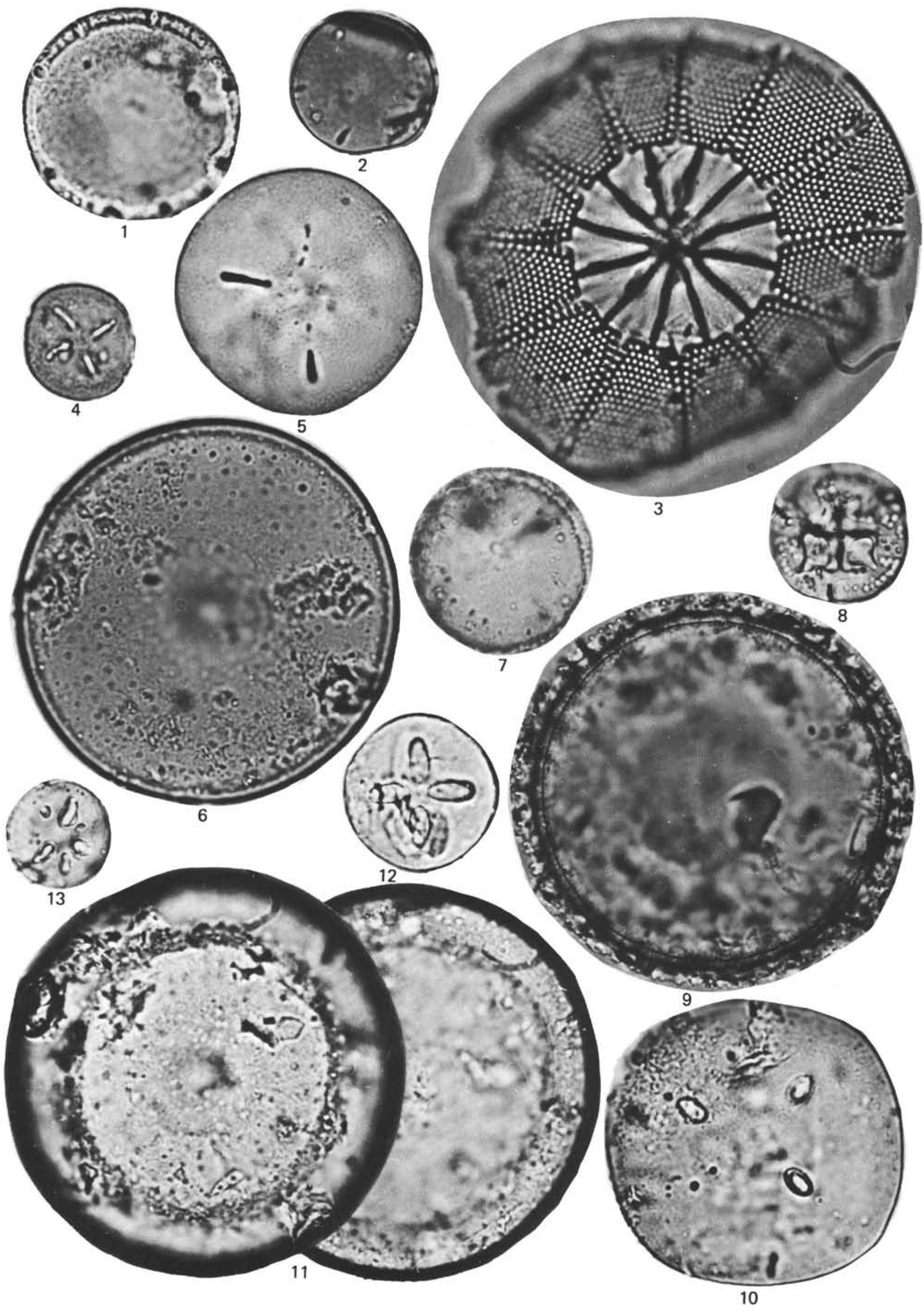




\section{PLATE 19}

Figures 1-3 Pyrgupyxis gracilis (Tempère and Forti) Hendey (1969).

1. Sample 356-6-4, 30-31 cm, $1500 \times$.

2. Sample 356-6-6, 30-31 cm, 1000X.

3. Sample $356-6-2,30-31 \mathrm{~cm}, 1000 \times$.

Figures 4-7 Pyrgupyxis gracilis var. saratoviana (Pantocsek) Hendey (1969).

4. Sample 356-6-2, 30-31 cm, 1000X.

5. Sample 356-6-2, 30-31 cm, 1000X.

6. Sample $356-7-5,30-31 \mathrm{~cm}, 1000 \times$.

7. Sample $356-6-2,30-31 \mathrm{~cm}, 1200 \times$.

Figure 8 Pyrgupyxis prolongata (Brun) Hendey (1969).

Sample $356-7-5,30-31 \mathrm{~cm}, 1200 \times$ (mounted).

Figure $9 \quad$ Pyrgupyxis sp.

Sample $356-6-3,30-31 \mathrm{~cm}, 750 \times$.

Figure $10 \quad$ Thalassionema nitzschioides Grunow var. parva Heiden in Heiden and Kolbe (1928).

Sample $358-2-4,30-31 \mathrm{~cm}, 1500 \times$.

Figure 11 Pyrgupyxis johnsoniana (Forti) Hendev (1969). Sample 356-6-2, 30-31 cm, 1000X.

Figures 12, 13 Pyrgupyxis gracilis (Temp. and Forti) Hendey var. buccinalis Forti (1909).

12. Sample $356-6-2,30-31 \mathrm{~cm}, 1500 \times$.

13. Sample $356-6-6,30-31 \mathrm{~cm}, 1000 \times$.

Figures 14-16 Pyrgupyxis sp. 1.

14. Sample $356-6-3,30-31 \mathrm{~cm}, 1500 \times$.

15,16 . Sample $356-6-2,30-31 \mathrm{~cm}, 1500 \times$ (same specimen).

Figure $17 \quad$ Pyrgupyxis sp. 2

Sample 356-6-4, 30-31 cm, 1500×.

Figure 18 Pyrgupyxis gracilis (Temp. and Forti) Hendey var. buccinalis Forti (1909).

Sample 356-6-5, 30-31 cm, 1000x. 
PLATE 19

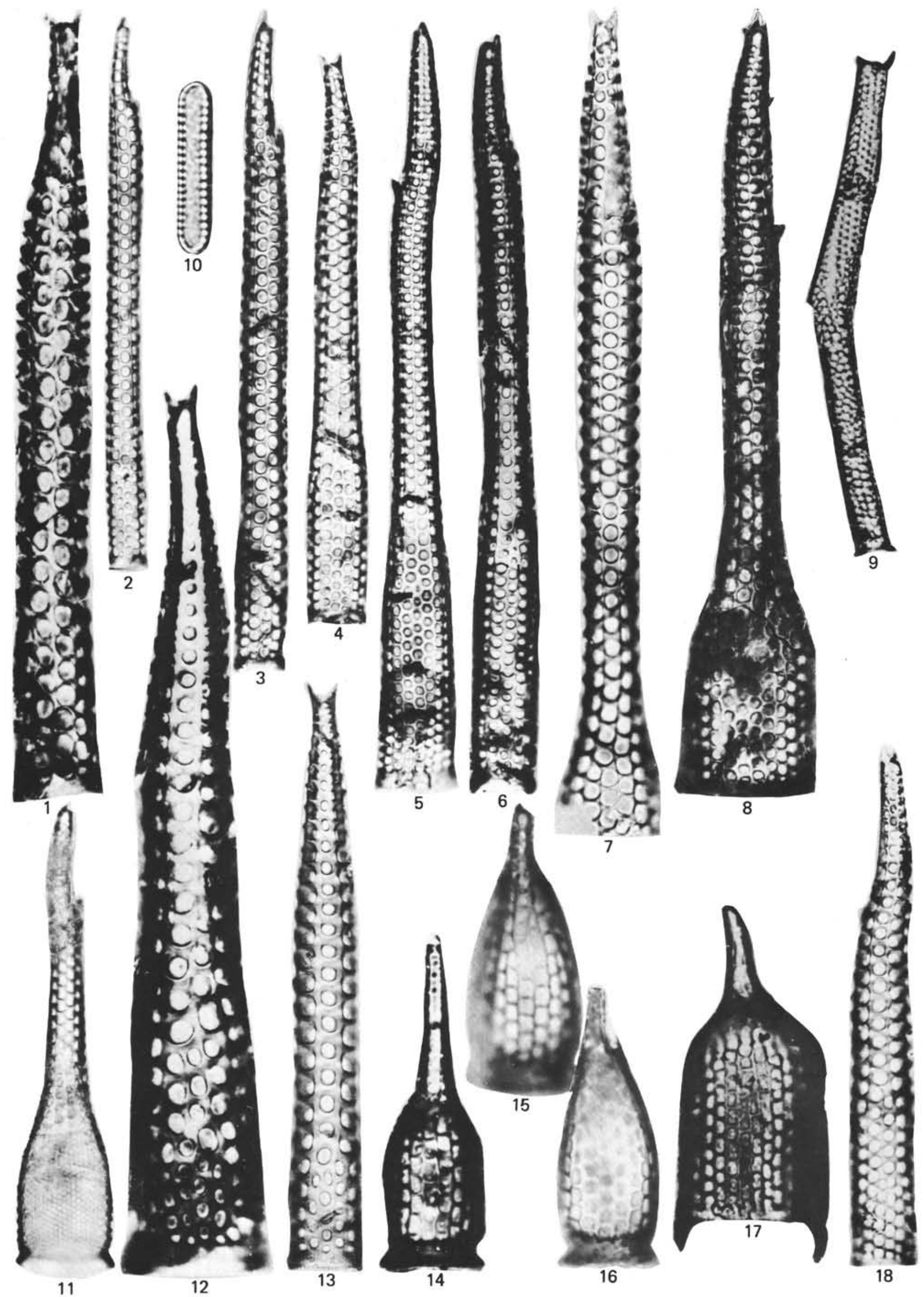


PLATE 20

Magnification 1500×, except Figures 2,3, 1200×

Figure $1 \quad$ Pyrgupyxis johnsoniana (Forti) Hendey (1969) Sample 356-7-4, 32-33 cm.

Figures 2, 3 Pyrgupyxis caput-avis (Brun) Hendey (1969). Sample 356-6-2, $30-31 \mathrm{~cm}, 1200 \times$.

Figure 4 Hemiaulus echinulatus? Jousé (1949).

Sample 356-6-4, 30-31 cm.

Figure 5 Hemiaulus exiguus Greville (1865).

Sample 356-7-4, 32-33 cm.

Figure 6 Hemiaulus sp. (a).

Sample 356-6-3, 30-31 cm.

Figure 7 Thalassionema hirosakiensis (Kanaya) Schrader (1973).

Sample 358-1-6, 30-31 cm.

Figure $8 \quad$ Thalassionema nitzschioides Grunow var. parva Heiden in Heiden and Kolbe (1928).

Sample 358-2-4, 30-31 cm.

Figure $9 \quad$ Rhizosolenia sp. 1.

Sample 356-7-5, 30-31 cm.

Figures 10,11 Rhizosolenia hebetata var. subacuta Grunow (1884).

10. Sample 358-1-4, 90-91 cm.

11. Sample $358-2-4,30-31 \mathrm{~cm}$.

Figure 12 Rhizosolenia sp. e Koizumi (1973).

Sample 356-6-4, 30-31 cm.

Figure $13 \quad$ Rhizosolenia sp.

Sample 358-2-2, 30-31 cm.

Figure $14 \quad$ Monobranchia sp.

Sample 356-8-1, $51-52 \mathrm{~cm}$.

Figure $15 \quad$ Monobranchia simplex Schrader in Schrader and Fenner (in press).

Sample $356-6-4,30-31 \mathrm{~cm}$.

Figure $16 \quad$ Monobranchia unicornuta (Brun) Schrader and Fenner (in press).

Sample 356-6-6, 30-31 cm.

Figure 17 Pyrgupyxis caput-avis (Brun) Hendey var. gracilis Tempere in Forti (1909).

Sample 356-9-2, 30-31 cm.

Figure 18 Pyrgupyxis johnsoniana (Forti) Hendey (1969) var. Sample 356-6-4, 30-31 cm.

Figure $19 \quad$ Monobranchia sp. 1.

Sample $356-7-5,30-31 \mathrm{~cm}$. 
PLATE 20

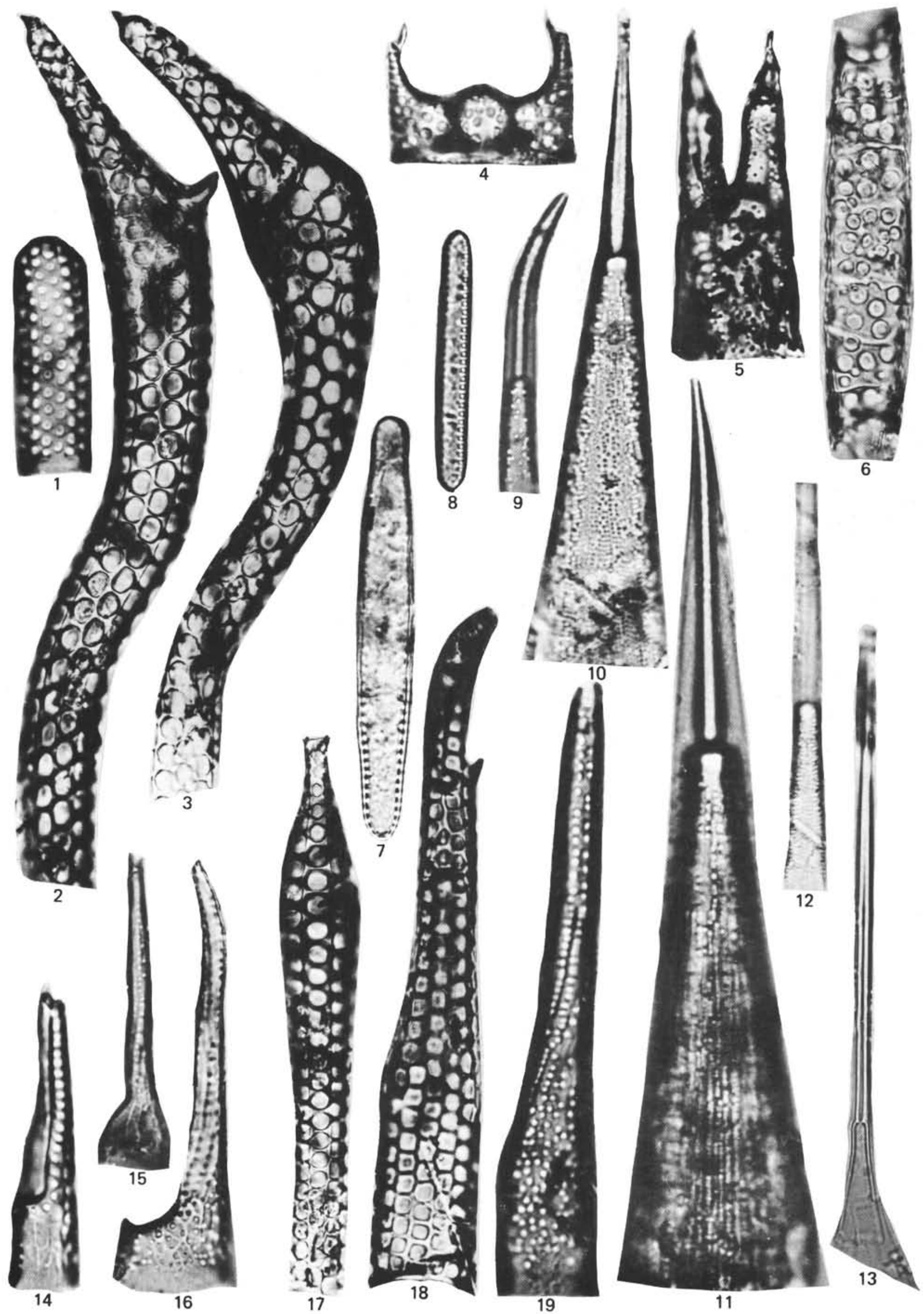


PLATE 21

Magnification $1500 \times$

Figure 1

Hemiaulus bipons (Ehrb.?) Grunow in Van Heurck (1896).

Sample 354-12-3, 2-3 cm.

Figure 2 Hemiaulus proteus? Heiberg (1863).

Sample 356-6-3, 30-31 cm.

Figures 3,4 Hemiaulus proteus Heiberg (1863).

Sample 356-6-3, 30-31 cm; Figure 4 mounted.

Figure 5 Hemiaulus sp.

Sample 356-9-2, 30-31 cm.

Figures 6-8 Hemiaulus weissii Grunow (1884).

6. Sample 356-6-2, 30-31 cm.

7. Sample $356-6-2,30-31 \mathrm{~cm}$.

8. Sample $356-9-2,30-31 \mathrm{~cm}$.

Figure 9 Hemiaulus weissii? Grunow (1884). Sample 356-6-6, 30-31 cm.

Figure 10 Hemiaulus weissii Grunow (1884).

Sample 356-6-4, 30-31 cm.

Figure 11 Hemiaulus ploymorphus Grunow (1884). FastigataType, working name).

Sample 356-7-5, 30-31 cm.

Figure $12 \quad$ Hemiaulus sp. 7.

Sample 356-7-6, 30-31 cm.

Figures 13, 14 Hemiaulus polycystinorum Ehrenberg (1854)

13. Sample $356-6-6,30-31 \mathrm{~cm}$.

14. Sample 356-6-2, 30-31 cm.

Figure $15 \quad$ Hemiaulus aff. weissii Grunow (1884).

Sample 356-6-4, 30-31 cm.

Figures 16, 17 Hemiaulus aff. hostilis Heiberg (1863).

Sample 356-6-2, 30-31 cm. 
PLATE 21
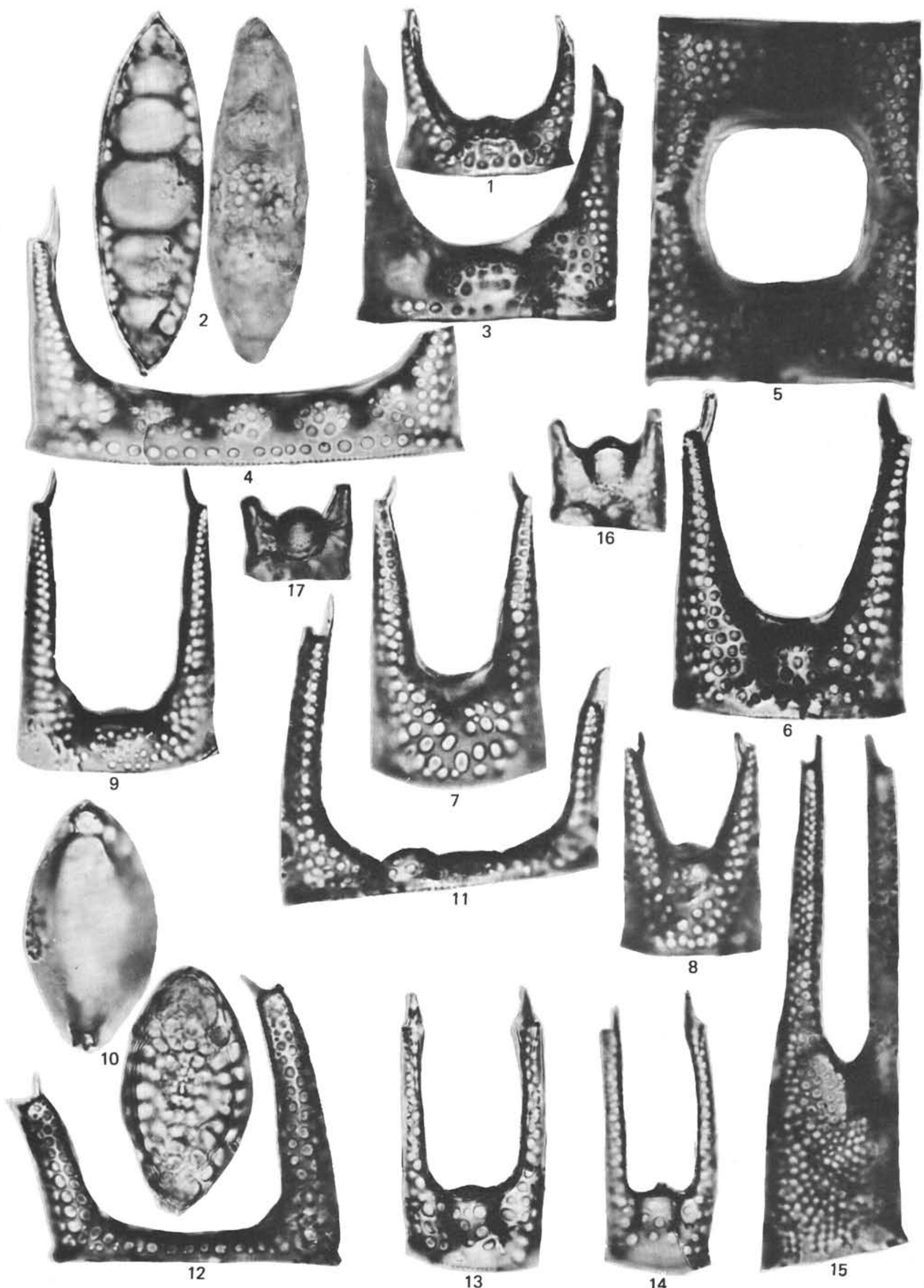


\section{PLATE 22 \\ Magnification $1500 \times$, except Figure 11, 1200×}

Figures 1-3 Pseudorocella barbadensis Deflandre (1938).

1. Sample 356-6-2, 30-31 cm.

2. Sample 354-12-6, $40-41 \mathrm{~cm}$.

3. Sample $356-6-5,30-31 \mathrm{~cm}$.

Figures 4, 5 Hemiaulus polycystinorum Ehrenberg (1854).

4. Sample 356-6-4, 30-31 cm (mounted).

5. Sample $356-6-3,30-31 \mathrm{~cm}$ (mounted).

Figure 6 Hemiaulus mucronatus Greville (1865).

Sample 356-6-2, 30-31 cm.

Figures 7-10 Hemiaulus polycystinorum Ehrenberg (1854).

7. Sample 356-6-3, 30-31 cm.

8. Sample $356-6-4,30-31 \mathrm{~cm}$.

9. Sample $356-6-4,30-31 \mathrm{~cm}$.

10. Sample $354-12-1,49-50 \mathrm{~cm}$.

Figures 11, 12 Hemiaulus crenatus Greville (1865).

11. Sample $356-7-1,30-31 \mathrm{~cm}, 1200 \times$.

12. Sample $356-6-4,30-31 \mathrm{~cm}$.

Figure 13 Hemiaulus polymorphus Grunow (1884) (Fastigata-type, working name).

Sample 356-6-5, 30-31 cm.

Figures 14-16 Hemiaulus polycystinorum Ehrenberg var. dissona n. var.

14. Sample $356-6-3,30-31 \mathrm{~cm}$.

15. Sample $356-6-2,30-31 \mathrm{~cm}$ (mounted); Holotype.

16. Sample $356-6-3,30-31 \mathrm{~cm}$. 
PLATE 22
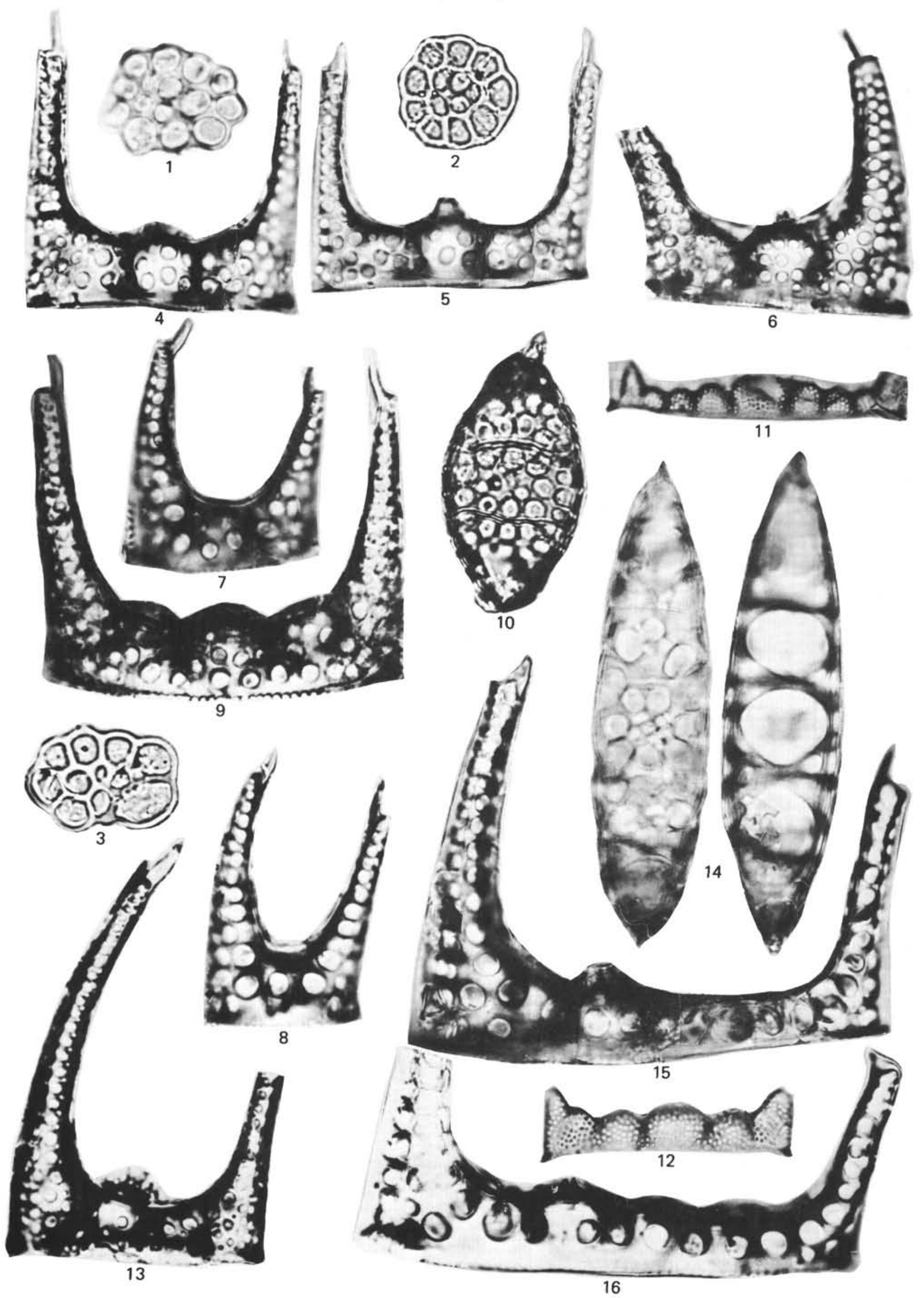
PLATE 23

Magnification $1500 \times$

Figures 1-4 Hemiaulus polycystinorum Ehrenberg (1854).

1. Sample 356-6-2, 30-31 cm.

2. Sample 356-9-2, 30-31 cm.

3. Sample 356-6-6, 30-31 cm.

4. Sample $356-6-5,30-31 \mathrm{~cm}$.

Figures 5-9 Hemiaulus polycystinorum Ehrenberg var. mesolepta Grunow (1884).

5. Sample 356-7-6, 30-31 cm.

6. Sample $356-7-6,30-31 \mathrm{~cm}$.

7. Sample $356-9-2,30-31 \mathrm{~cm}$.

8. Sample $356-6-3,30-31 \mathrm{~cm}$.

9. Sample $356-6-4,30-31 \mathrm{~cm}$.

Figure 10 Hemiaulus polymorphus Grunow (1884) fastigatatype, (working name).

Sample 356-6-2, 30-31 cm.

Figure 11 Hemiaulus polymorphus Grunow (1884). Sample 354-12-2, 14-15 cm.

Figure 12 Hemiaulus sp. 1.

Sample 356-7-3, 30-31 cm.

Figures 13-16 Pseudorocella barbadensis Deflandre (1938).

13. Sample 356-6-2, 30-31 cm.

14. Sample $356-7-5,30-31 \mathrm{~cm}$.

15. Sample 356-6-2, 30-31 cm.

16. Sample $356-6-2,30-31 \mathrm{~cm}$. 
PLATE 23
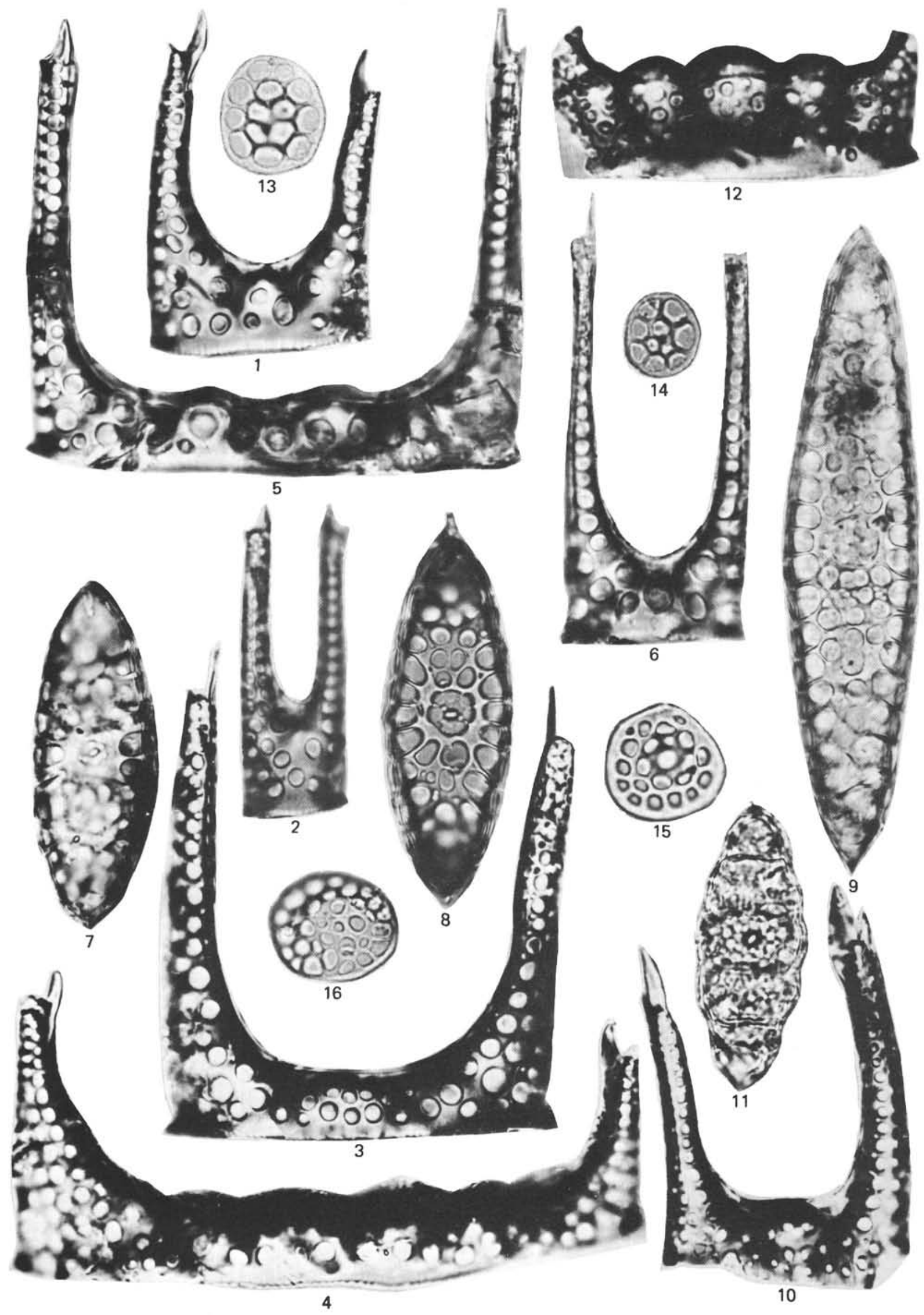


\section{PLATE 24}

Magnification $1500 \times$, except Figures 11, 18, 1000×

Figures 1-5 Xanthiopyxis structuralis $\mathrm{n} . \mathrm{sp}$.

1. Sample 356-8-1, $51-52 \mathrm{~cm}$.

2. Sample 356-6-6, 30-31 cm.

3. Sample 356-8-1, 51-52 cm, (Holotype).

4. Sample $356-9-2,30-31 \mathrm{~cm}$.

5. Sample $354-12-4,13-14 \mathrm{~cm}$.

Figure $6 \quad$ Hemiaulus sp. 3.

Sample 356-6-4, 30-31 cm.

Figure 7 Hemiaulus polycystinorum Ehrenberg var. mesolepta Grunow (1884).

Sample 356-6-3, 30-31 cm.

Figure $8 \quad$ Hemiaulus subacutus Grunow (1884).

Sample 354-12-1, 49-50 cm.

Figure $9 \quad$ Hemiaulus sp. 7.

Sample 356-7-4, 32-33 cm.

Figure $10 \quad$ Hemiaulus sp.

Sample 356-9-2, 30-31 cm.

Figure 11 Riedelia longicornis (Greville) Schrader and Fenner (in press).

Sample 356-6-4, 30-31 cm, 1000×.

Figure $12 \quad$ Hemiaulus sp. 6.

Sample 356-7-2, 30-31 cm.

Figure 13 Hemiaulus mucronatus Greville (1865).

Sample 356-9-2, 30-31 cm.

Figure $14 \quad$ Hemiaulus subacutus Grunow (1884).

Sample 354-12-1, 49-50 cm.

Figure $15 \quad$ Hemiaulus altus Hajós (1975).

Sample 356-7-6, 30-31 cm.

Figures 16, 17 Trinacria pileolus (Ehrenberg) Grunow (1884).

Sample 356-9-2, 30-31 cm; lateral view.

Figure 18 Riedelia longicornis (Greville) Schrader and Fenner (in press, b).

Sample 356-6-2, 30-31 cm, 1000X. 
PLATE 24
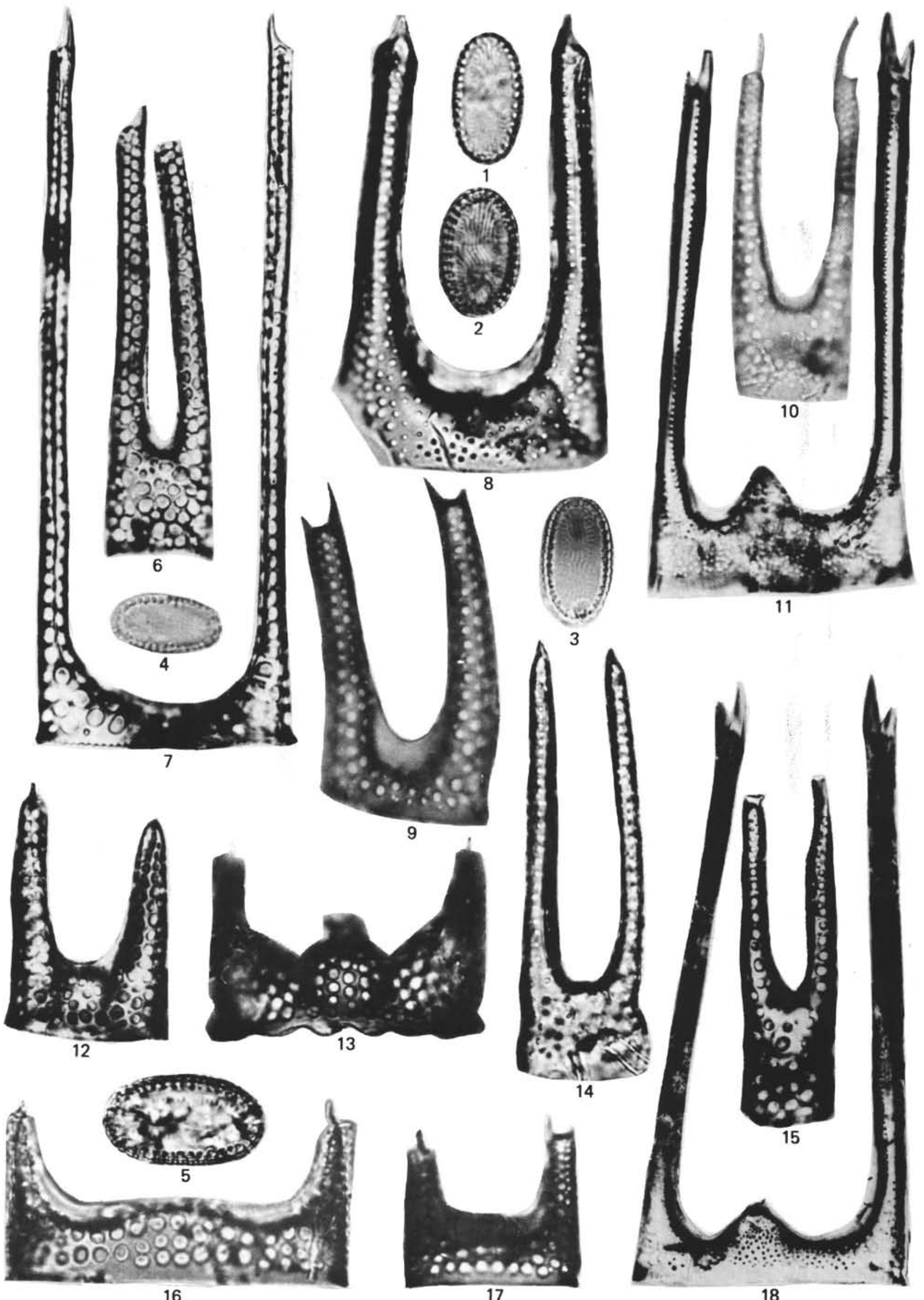
PLATE 25

Magnification $1500 \times$, except Figures 1, 11, 1200×

Figure 1 Genus and species indet. (A) Gombos (in press). Sample $356-7-4,30-31 \mathrm{~cm}, 1200 \times$.

Figure 2 Riedelia tenuicornis (Greville) Schrader and Fenner (in press, b).

Sample 356-7-6, 30-31 cm.

Figure 3 Riedelia altar (Brun) Schrader and Fenner (in press, b).

Sample $356-8-1,51-52 \mathrm{~cm}$.

Figure 4 Genus and species indet. (A) Gombos (in press, b). Sample 356-9-2, 30-31 cm.

Figure $5 \quad$ Hemiaulus sp. 2.

Sample 356-8-1, 51-52 cm.

Figure 6 Hemiaulus incisus Hajós (1976).

Sample 356-9-2, 30-31 cm.

Figure $7 \quad$ Genus and species indet.

Sample 356-8-1, 51-52 cm.

Figure 8 Hemiaulus incisus Hajós (1976).

Sample 356-9-2, 30-31 cm.

Figure 9 Riedelia tenuicornis (Greville) Schrader and Fenner (in press, b).

Sample $356-6-4,30-31 \mathrm{~cm}$.

Figure 10 Genus and species indet. (A) Gombos (in press). Sample $356-7-4,32-33 \mathrm{~cm}$.

Figure 11 Riedelia claviger (A. Schmidt) Schrader and Fenner (in press, b).

Sample $356-6-2,30-31 \mathrm{~cm}, 1200 \times$.

Figure 12 Hemiaulus klushnikovii Gleser in SheshukovaPoretzkaya and Gleser (1964).

Sample 356-7-6, 30-31 cm.

Figure 13 Riedelia altar (Brun) Schrader and Fenner (in press, b).

Sample $356-9-2,30-31 \mathrm{~cm}$.

Figures 14,15 Hemiaulus klushnikovii Gleser in SheshukovaPoretzkaya and Gleser (1964).

14. Sample $356-8-2,30-31 \mathrm{~cm}$.

15. Sample 356-7-3, 30-31 cm. 
PLATE 25

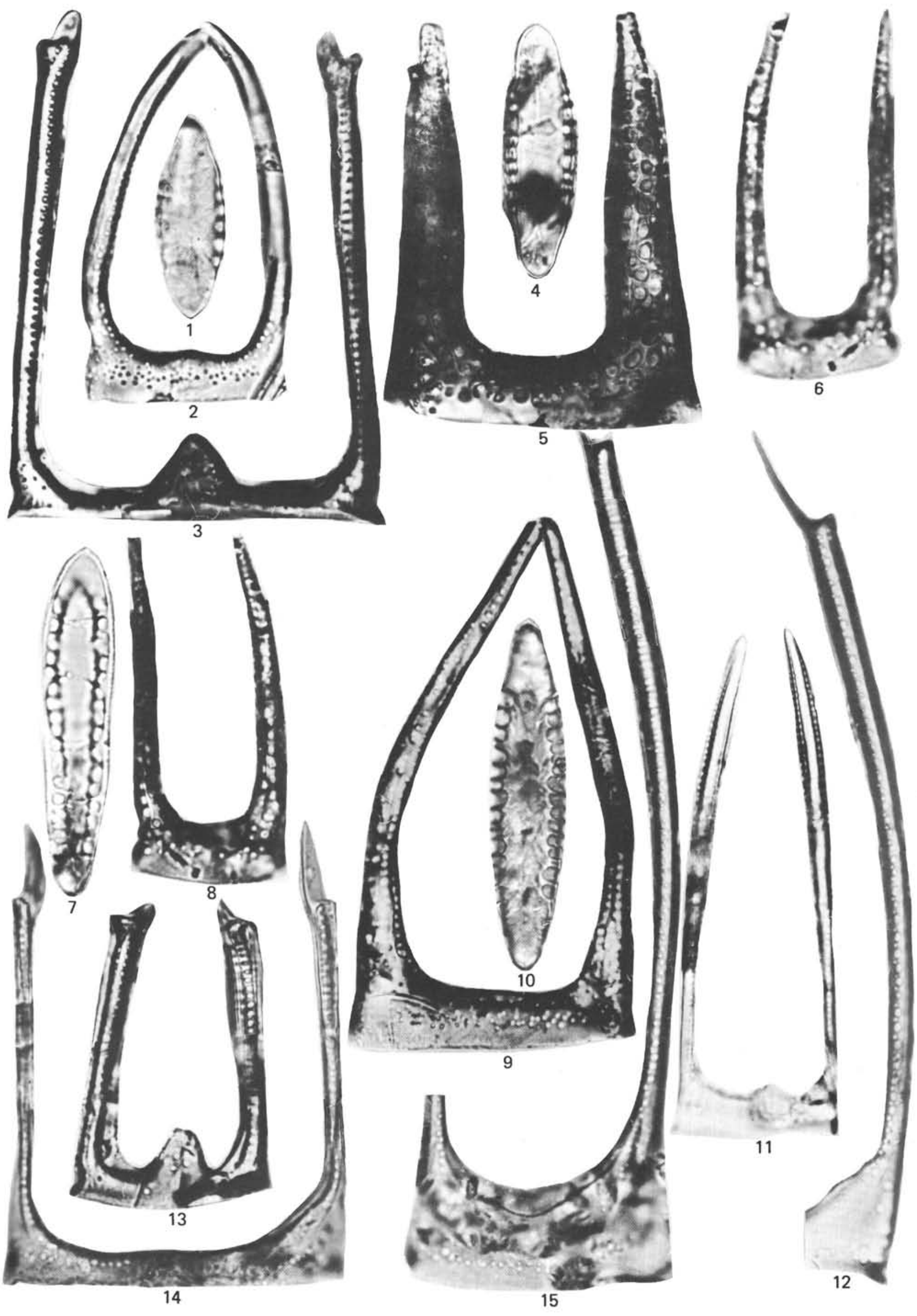


PLATE 26

Magnification 1500×, except figures 12,18, 1000×

Figures 1,2 Riedelia alata (Greville) Schrader and Fenner (in press).

1. Sample 356-6-6, 30-31 cm.

2. Sample $356-6-2,30-31 \mathrm{~cm}$, (mounted).

Figures 3-5 Riedelia sublevata $\mathrm{n}$. sp.

3. Sample 356-6-2, 30-31 cm.

4. Sample $356-6-5,30-31 \mathrm{~cm}$, (mounted).

5. Sample 356-6-6, 30-31 cm, (mounted); Holotype.

Figure 6 Pseudorutilaria monomembranacea Schrader in Schrader and Fenner (in press, b).

Sample 356-6-4, 30-31 cm.

Figure $7 \quad$ Goniothecium odontella Ehrenberg (1844).

Sample 356-7-2, 30-31 cm.

Figure 8 Pseudorutilaria monomembranacea Schrader in Schrader and Fenner (in press, b).

Sample 356-6-6, 30-31 cm.

Figure $9 \quad$ Ploiaria petasiformis Pantocsek (1889).

Sample 356-6-2, 30-31 cm.

Figure $10 \quad$ Riedelia $\mathrm{sp} .1$.

Sample 356-9-2, 30-31 cm.

Figure 11 Hemiaulus weissflogii Pantocsek (1889).

Sample 356-8-1, 51-52 cm.

Figure 12 Riedelia borealis Sheshukova-Poretzkaya (1971).

Sample 356-6-2, 30-31 cm, 1000x.

Figures 13,14 Campylosira sp.

13. Sample $354-12-6,40-41 \mathrm{~cm}$.

14. Sample $356-8-1,51-52 \mathrm{~cm}$.

Figure $15 \quad$ Riedelia sublevata n. $\mathrm{np}$.

Sample 356-6-2, 30-31 cm.

Figure $16 \quad$ Sceptroneis pesplanus Schrader and Fenner (in press, b).

Sample 356-6-6, 30-31 cm.

Figure 17 Hemiaulus? stabilus n. sp.

Sample 356-6-2, 30-31 cm; (Holotype).

Figure $18 \quad$ Riedelia borealis Sheshukova-Poretzkaya (1971).

Sample 356-6-6, 30-31 cm, 1000×. 
PLATE 26
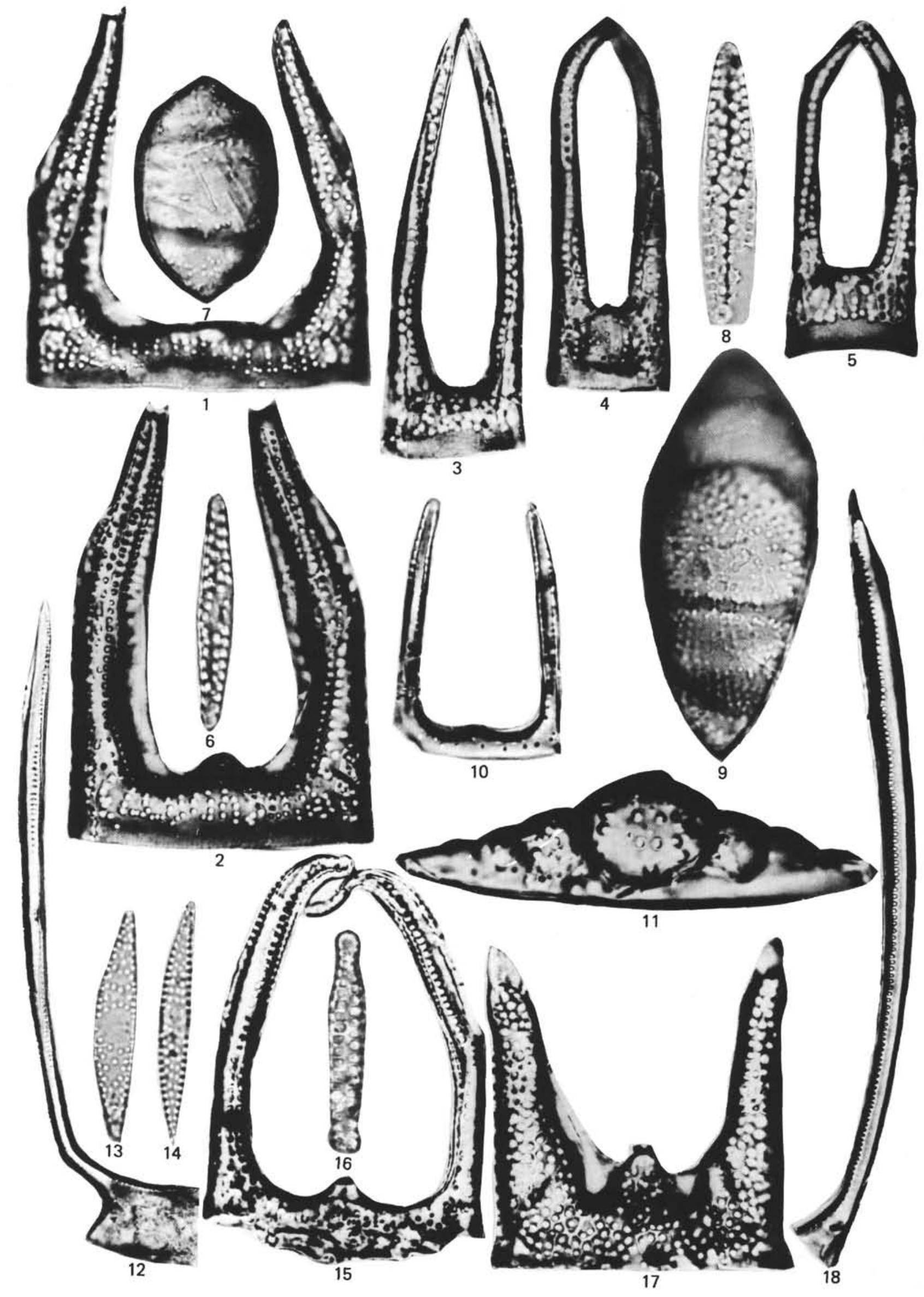


\section{PLATE 27}

Magnification $1500 \times$

Figure $1 \quad$ Goniothecium odontella Ehrenberg (1844). Sample 356-7-4, 32-33 cm.

Figure 2 Trinacria subcapitata (Greville) Grunow (1884). Sample 354-12-3, 2-3 cm.

Figures 3-5 Eunotogramma weissii Ehrenberg var. producta Grove and Sturt (1887).

3. Sample $356-7-4,32-33 \mathrm{~cm}$.

4. Sample $356-7-5,30-31 \mathrm{~cm}$.

5. Sample $356-7-3,30-31 \mathrm{~cm}$.

Figure $6 \quad$ Triceratium delicatum Greville (1861).

Sample 356-6-4, 30-31 cm.

Figures 7,8 Trinacria subcapitata (Greville) Grunow (1884).

7. Sample $354-12-3,2-3 \mathrm{~cm}$.

8. Sample $354-12-1,49-50 \mathrm{~cm}$.

Figures 9-11 Trinacria excavata Heiberg forma tetragona A. Schmidt (1888).

9. Sample 356-8-2, 30-31 cm.

10. Sample 356-6-3, 30-31 cm.

11. Sample 356-6-4, 30-31 cm.

Figures 12-15 Eucampia balaustium Castracane (1886).

12. Sample $358-1-3,30-31 \mathrm{~cm}$.

13. Sample $358-1-3,30-31 \mathrm{~cm}$.

14. Sample 358-1-4, $90-91 \mathrm{~cm}$.

15. Sample 358-1-4, $90-91 \mathrm{~cm}$.

Figure $16 \quad$ Sceptroneis pesplanus Schrader and Fenner (in press, b).

Sample 356-7-3, 30-31 cm. 
PLATE 27

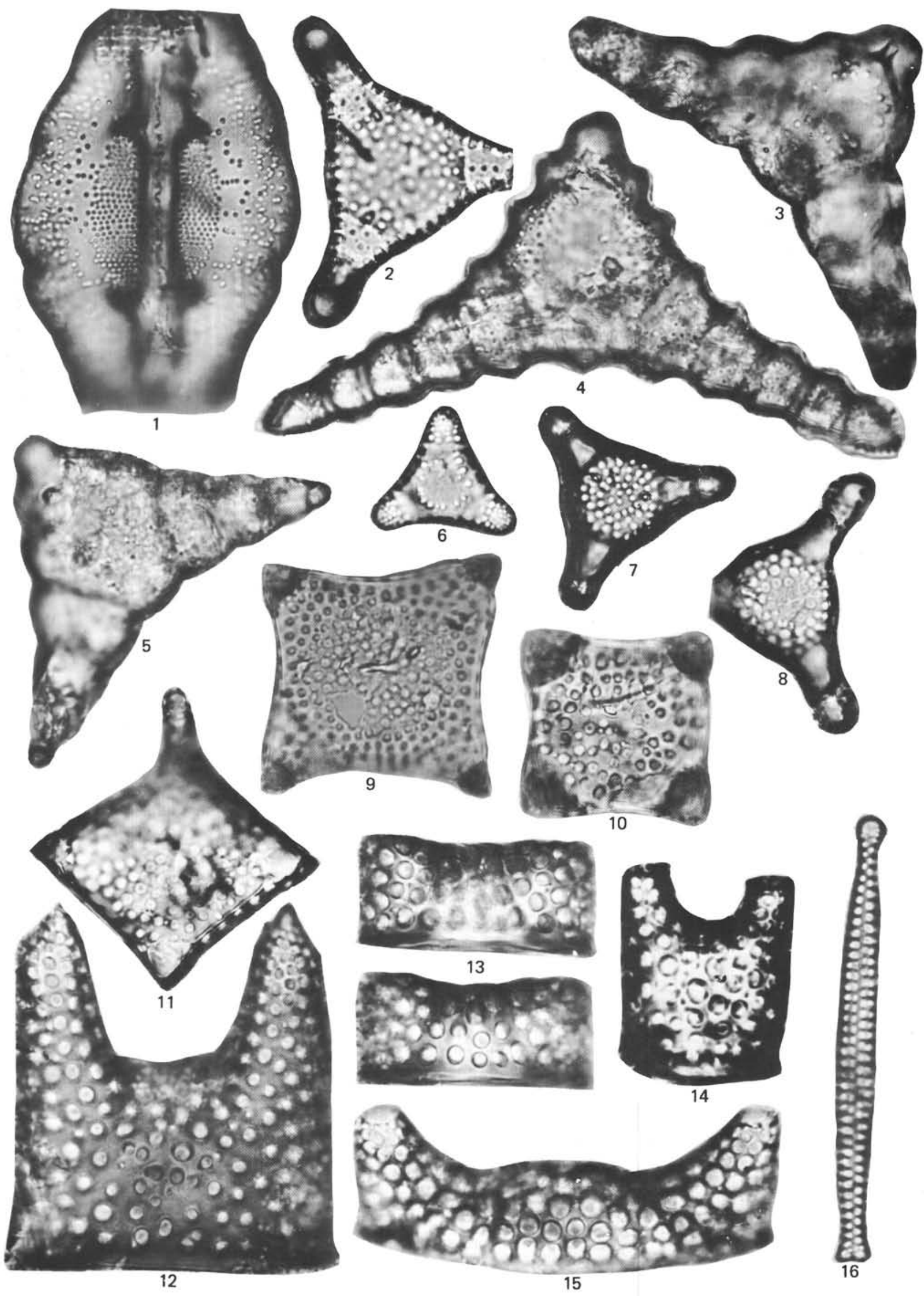


PLATE 28

Magnification 1500×, except Figure 1, 1000×

Figures 1, 2 Triceratium groningensis Reinhold (1937).

1. Sample 356-9-2, 30-31 cm, 1000×.

2. Sample $354-12-1,49-50 \mathrm{~cm}$.

Figures 3,4 Pseudodimerogramma sp. 1. Sample 354-12-3, 2-3 cm.

Figure $5 \quad$ Triceratium sp.

Sample 358-2-2, 30-31 cm.

Figure $6 \quad$ Stictodiscus parallelus (Ehrenberg) Grove and Sturt (1887).

Sample 356-8-1, 51-52 cm.

Figure $7 \quad$ Triceratium condecorum Brightwell (1853).

Sample 354-12-5, 82-83 cm.

Figure 8 Triceratium seychellense Grunow Van Heurck (1883).

Sample 356-6-3, 30-31 cm.

Figures 9, $10 \quad$ Pseudodimerogramma sp. 1.

Sample 354-12-3, 2-3 cm.

Figure 11 Triceratium sp. 1.

Sample 356-6-3, 30-31 cm. 
PLATE 28

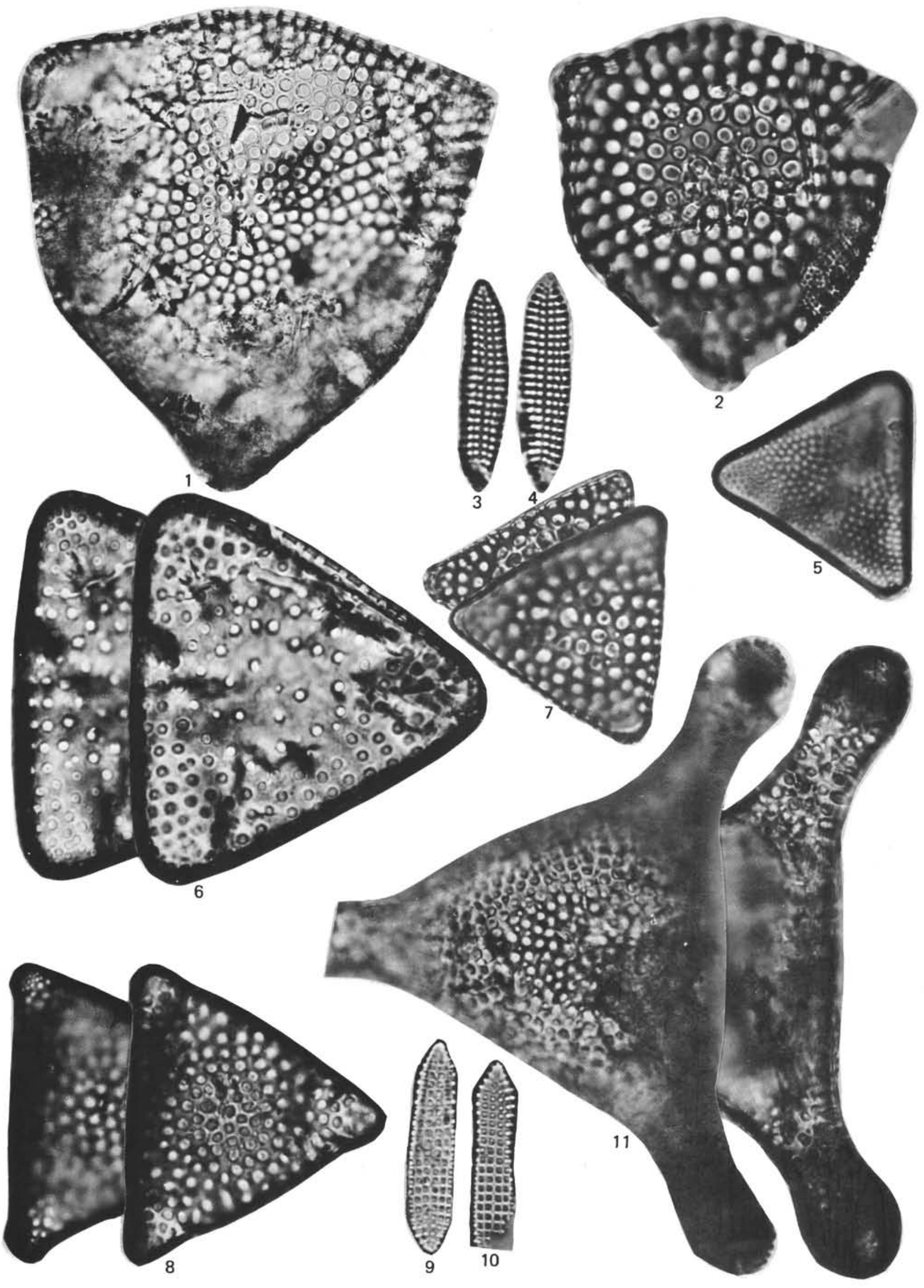


PLATE 29

Magnification $1500 \times$, except Figure 2, 750×

Figure 1 Triceratium condecorum Brightwell (1853). Sample 356-6-4, 30-31 cm.

Figure 2 Trinacria simulacrum Grove and Sturt (1887). Sample $356-7-5,30-31 \mathrm{~cm}, 750 \times$.

Figure 3 Raphoneis sp. 1. Sample 356-6-4, 30-31 cm.

Figure $4 \quad$ Sceptroneis sp. 1. Sample 354-12-6, 40-41 cm.

Figure 5 Triceratium indefinitum (Jousé) Strelnikova (1974). Sample 356-6-6, 30-31 cm.

Figure $6 \quad$ Raphoneis angustata Pantocsek (1886). Sample 354-12-3, 2-3 cm.

Figure 7 Triceratium indefinitum (Jousé) Strelnikova (1974). Sample 356-6-5, 30-31 cm.

Figure $8 \quad$ Eunotogramma productum Grunow in Van Heurck (1883).

Sample 356-6-2, 30-31 cm.

Figure 9 Triceratium castelliferum Grunow in Schmidt et al. (1874-).

Sample 356-9-2, 30-31 cm. 
PLATE 29

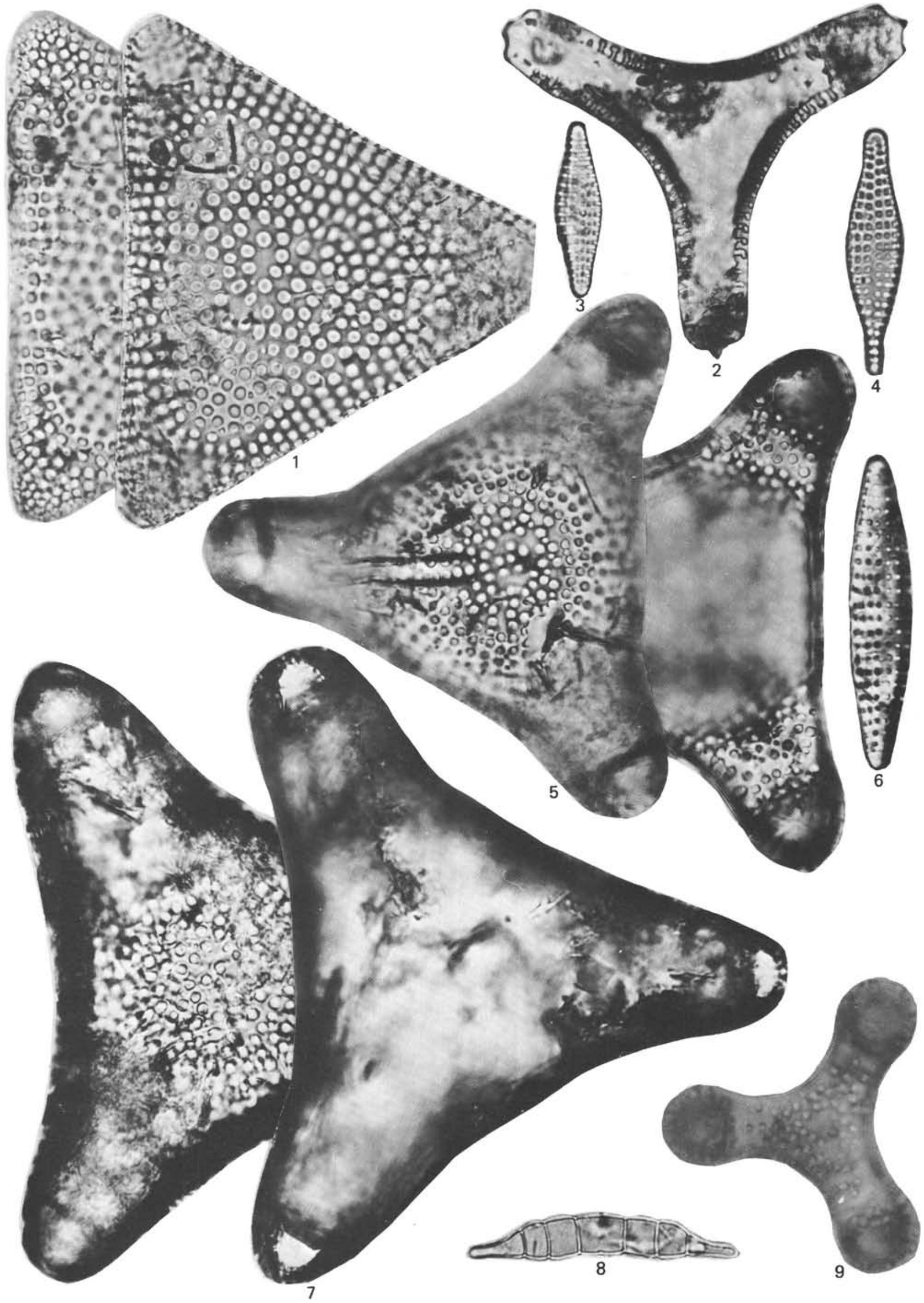


PLATE 30

Magnification $1500 \times$

Figures 1-11 Triceratium schulzii Jousé (1949).

1. Sample 356-8-1, 51-52 cm.

2. Sample $356-6-5,30-31 \mathrm{~cm}$.

3. Sample 356-9-2, 30-31 cm.

4. Sample 356-9-2, 30-31 cm.

5. Sample $356-9-2,30-31 \mathrm{~cm}$.

6. Sample $356-7-5,30-31 \mathrm{~cm}$.

7. Sample 356-9-2, 30-31 cm.

8. Sample $356-9-2,30-31 \mathrm{~cm}$.

9. Sample 356-9-2, 30-31 cm.

10. Sample $356-9-2,30-31 \mathrm{~cm}$.

11. Sample 356-6-3, 30-31 cm.

Figures 12-14 Triceratium barbadense Greville (1861).

12. Sample 356-7-3, 30-31 cm.

13. Sample $356-7-5,30-31 \mathrm{~cm}$.

14. Sample $356-7-4,30-31 \mathrm{~cm}$.

Figures 15-20 Triceratium schulzii Jousé var. quadrilobata $\mathrm{n}$. var.

15. Sample $356-9-2,30-31 \mathrm{~cm}$.

16. Sample $356-9-2,30-31 \mathrm{~cm}$.

17. Sample $356-8-1,51-52 \mathrm{~cm}$.

18. Sample 356-8-1, $51-52 \mathrm{~cm}$.

19. Sample $356-9-2,30-31 \mathrm{~cm}$. (Holotype).

20. Sample $356-9-2,30-31 \mathrm{~cm}$.

Figures 21, 22 Triceratium inconspicuum Greville (1861).

21. Sample 356-6-2, 30-31 cm.

22. Sample $356-6-5,30-31 \mathrm{~cm}$.

Figures 23-26 Triceratium inconspicuum Greville var. trilobata $\mathrm{n}$. var.

23. Sample 356-6-2, 30-31 cm.

24. Sample $356-6-4,30-31 \mathrm{~cm}$.

25. Sample 356-7-6, 30-31 cm (Holotype).

26. Sample $356-7-6,30-31 \mathrm{~cm}$.

Figures 27-31 Triceratium brachiatum Brightwell (1856).

27. Sample 356-7-2, 30-31 cm.

28. Sample $356-9-2,30-31 \mathrm{~cm}$.

29. Sample $356-9-2,30-31 \mathrm{~cm}$.

30. Sample $356-7-2,30-31 \mathrm{~cm}$.

31. Sample 356-6-2, 30-31 cm. 
PLATE 30

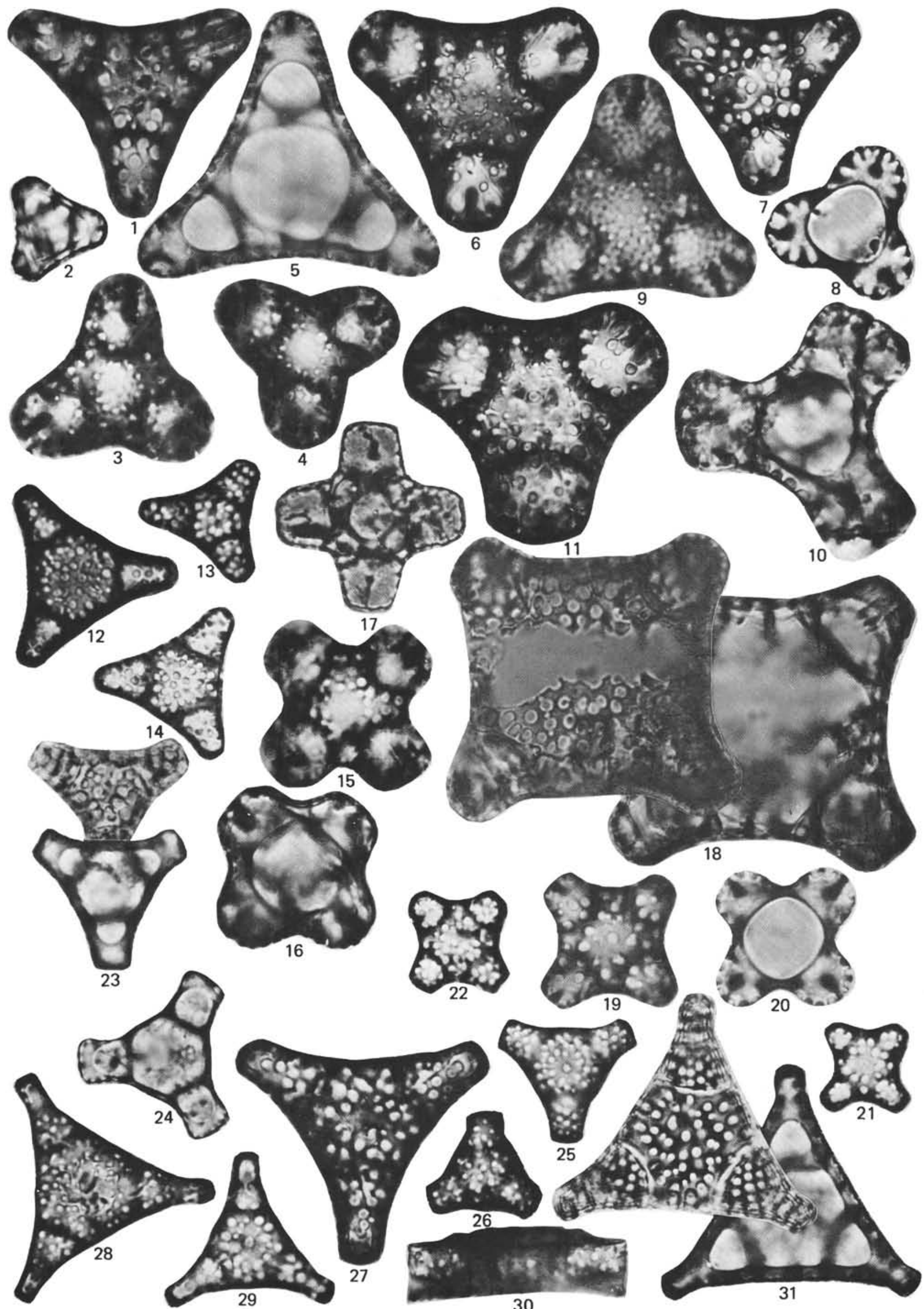




\section{PLATE 31}

Magnification 1500×, except Figures 2, 750×; 10, 1000×; 6,11,12, $1200 \times$

Figure 1 Triceratium acutangulum Strelnikova (1974). Sample 356-8-1, 51-52 cm.

Figure 2 Trinacria simulacrum Grove et Sturt (1887). Sample 356-9-2, 30-31 cm, 750X.

Figures 3-5 Biddulphia tridens Ehrenberg (1840). Sample 356-9-2, 30-31 cm.

Figure $6 \quad$ Peponia sp. 1. Sample 356-6-3, 30-31 cm, 1200×.

Figure $7 \quad$ Eunotogramma variabile Grunow in Van Heurck (1883).

Sample 356-9-2, 30-31 cm.

Figures 8-10 Sceptroneis ligulatus n. sp.

8. Sample 356-6-2, 30-31 cm.

9. Sample $356-7-5,30-31 \mathrm{~cm}$, (mounted).

10. Sample 356-6-6, 30-31 cm, 1000×; (Holotype).

Figures 11, 12 Biddulphia tridens Ehrenberg (1840).

Sample 356-8-1, 51-52 cm, 1200× (same specimen).

Figures 13,14 Hemiaulus ornithocephalus Greville var. A. Schmidt (1889).

Sample 356-7-6, 30-31 cm (same specimen).

Figures 15, 16 Eunotogramma variabile Grunow in Van Heurck (1883).

15. Sample $356-7-6,30-31 \mathrm{~cm}$.

16. Sample 356-6-6, 30-31 cm. 
PLATE 31

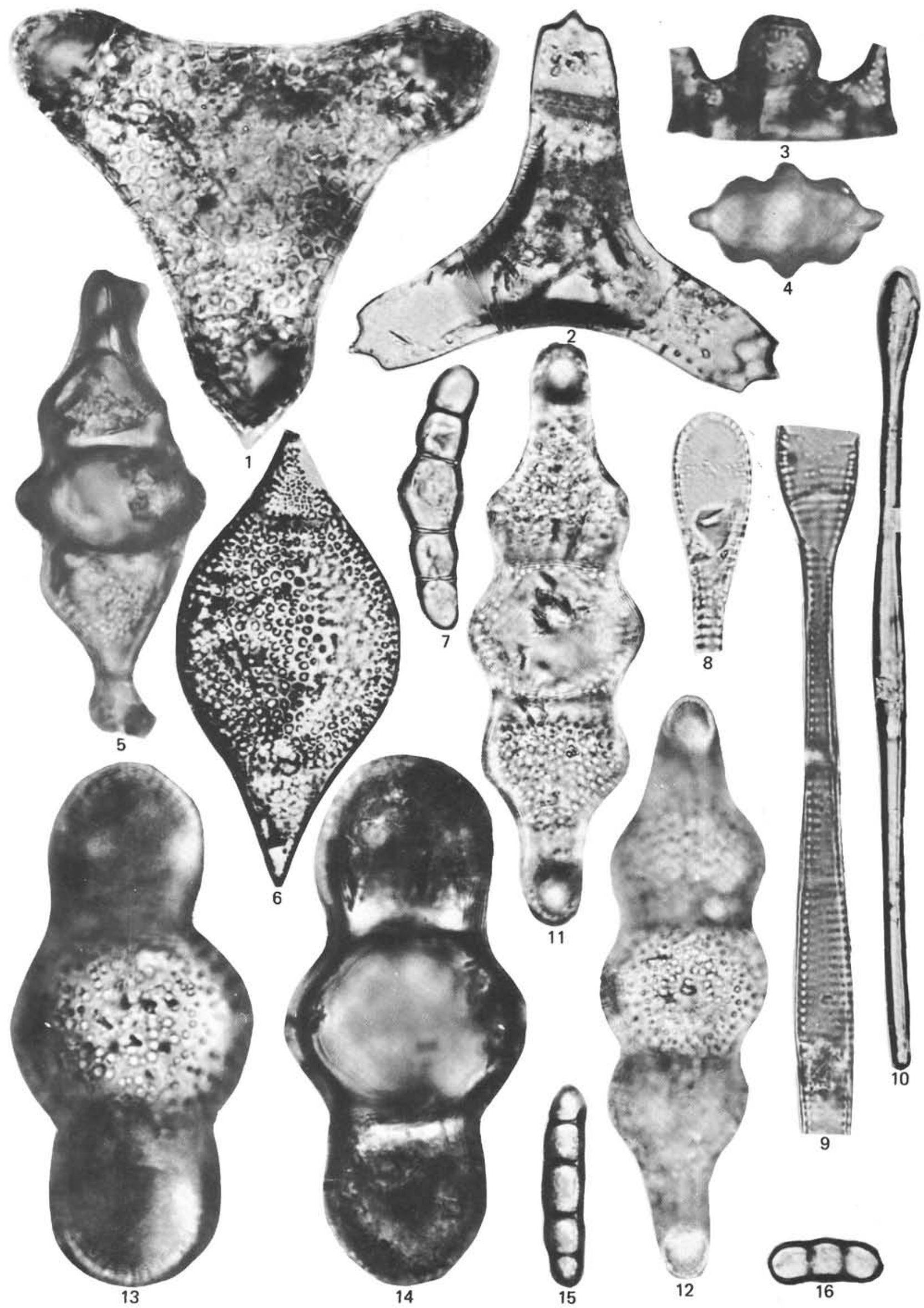


PLATE 32

Magnification $1500 \times$, except Figure 8, 1200×

Figure 1

Figures 2-5

Figure 6

Figure 7

Figure 8

Figure 9

Figure 10

Figure 11

Figure 12

Figure 13

Figure 14

Figure 15

Figure 16
Biddulphia weissflogii Janisch in Van Heurck (1884).

Sample 356-6-3, 30-31 cm.

Cymatosira sp. 1.

2. Sample 356-6-6, 30-31 cm.

3. Sample 356-6-4, 30-31 cm.

4. Sample 356-6-4, 30-31 cm.

5. Sample 354-12-2, 14-15 cm.

Rutilariopsis sp.

Sample 356-6-2, 30-31 cm.

Cymatonitzschia aff. marina (Lewis) Simonsen (1974).

Sample 358-1-3, 30-31 cm.

Sceptroneis tenue Schrader and Fenner (in press, b).

Sample 356-6-3, 30-31 cm, 1200x.

Baxteria formosa Brun (1896).

Sample 356-9-2, 30-31 cm.

Cymatosira sp. 2.

Sample 356-7-5, 30-31 cm.

Cymatosira aff. debyi Tempère and Brun (1889).

Sample 356-6-4, 30-31 cm.

Genus et species indet. Sample 356-9-2, 30-31 cm.

Cymatosira sp. 4.

Sample 356-6-2, 30-31 cm.

Cymatosira sp. 3.

Sample 356-6-2, 30-31 cm.

Rutilariopsis sp.

Sample 356-6-3, 30-31 cm.

Rutilariopsis sp. 1.

Sample 356-6-3, 30-31 cm.
Figure $17 \quad$ Cymatosira sp. 4.

Sample 356-6-5, 30-31 cm.

Figure $18 \quad$ Cymatosira sp. 5.

Sample 356-6-3, 30-31 cm.

Figure 19 Rutilariopsis? sp.

Sample 356-6-4, 30-31 cm.

Figure 20 Kisseleviella aff. carina SheshukovaPoretzkaya (1962).

Sample 356-6-3, 30-31 cm.

Figure 21 Denticula hustedtii Simonsen and Kanaya (1961).

Sample 358-2-4, 30-31 cm.

Figures 22,23 Nitzschia aff. miocenica Burckle (1972).

22. Sample 358-2-4, 30-31 cm.

23. Sample $358-2-1,30-31 \mathrm{~cm}$.

Figure $24 \quad$ Nitzschia sp. 2.

Sample 358-1-1, 30-31 cm.

Figure $25 \quad$ Nitzschia sp. 1.

Sample 358-1-3, 30-31 cm.

Figure $26 \quad$ Nitzschia sp.

Sample 358-2-4, $30-31 \mathrm{~cm}$.

Figures 27-29 Nitzschia panduraeformis Gregory (1857).

27. Sample $358-1-1,30-31 \mathrm{~cm}$.

28 , 29. Sample $358-1-3,30-31 \mathrm{~cm}$, (same specimen).

Figures 30,31 Rutilariopsis ventricosa (Brun) n. comb.

Sample 356-6-6, 30-31 cm, (same specimen). 
PLATE 32

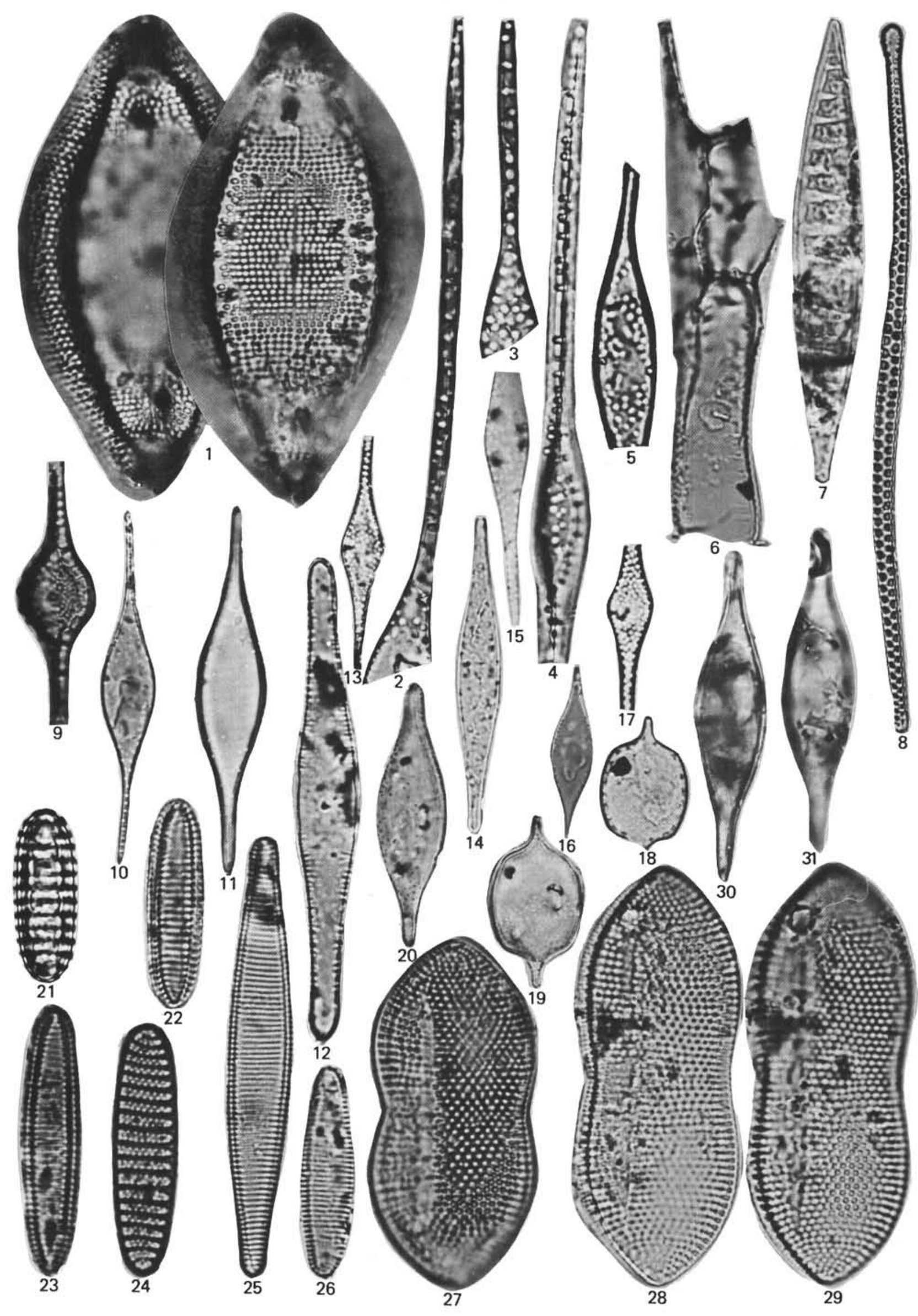


PLATE 33

Magnification 1500×, except Figures 16,17, 1000×;

Figure 21, 1200X

Figure $1 \quad$ Rouxia sp. 1.

Sample 358-1-6, 30-31 cm.

Figure $2 \quad$ Navicula sp. 2.

Sample 356-6-2, 30-31 cm.

Figure 3 Diploneis sp.

Sample 354-12-1, 49-50 cm.

Figure 4 Campyloneis grevillei (Wm. Smith) Grunow (1867).

Sample 354-12-1, 49-50 cm.

Figure 5 Thalassionema nitzschioides Grunow var. parva Heiden in Heiden et Kolbe (1928).

Sample 358-1-4, 90-91 cm.

Figure $6 \quad$ Navicula sp. 1.

Sample 356-6-5, 30-31 cm.

Figure 7 Eunotogramma variabile Grunow in Van Heurck (1883).

Sample 356-6-6, 30-31 cm.

Figure $8 \quad$ Genus and species indet.

Sample 356-9-2, 30-31 cm.

Figure 9 Archaemonadaceae, genus and species indet. (1). Sample 356-9-2, 30-31 cm.

Figure 10 Archaemonadaceae, genus and species indet. (d) Schrader and Fenner (in press, b).

Sample 356-7-6, 30-31 cm.

Figure 11 Archaemonadaceae, genus and species indet. (f) Schrader and Fenner (in press, b).

Sample 356-7-6, 30-31 cm.

Figure 12 Archaemonadaceae, genus and species indet. (e) Schrader and Fenner (in press, b).

Sample 356-6-4, 30-31 cm.

Figures 13, 14 Mastogloia splendida (Greg.) Cleve and Möller (1879).

13. Sample $354-12-5,82-83 \mathrm{~cm}$.

14. Sample $354-12-2,14-15 \mathrm{~cm}$.

Figures 15-20 Thalassiothrix longissima Cleve and Grunow (1880).

15. Sample $358-2-4,30-31 \mathrm{~cm}$.

16. Sample $358-1-5,30-31 \mathrm{~cm}, 1000 \times$.

17. Sample $358-1-6,30-31 \mathrm{~cm}, 1000 \times$.

18. Sample $358-1-4,90-91 \mathrm{~cm}$.

19. Sample $358-1-1,30-31 \mathrm{~cm}$.

20. Sample $358-2-2,30-31 \mathrm{~cm}$.

Figures 21, 22 Thalassionema robusta Schrader (1973).

21. Sample 358-1-4, 90-91 cm, $1200 \times$.

22. Sample $358-1-6,30-31 \mathrm{~cm}$.

Figure 23 Synedra miocenica Schrader (1976).

Sample 354-12-1, 49-50 cm. 


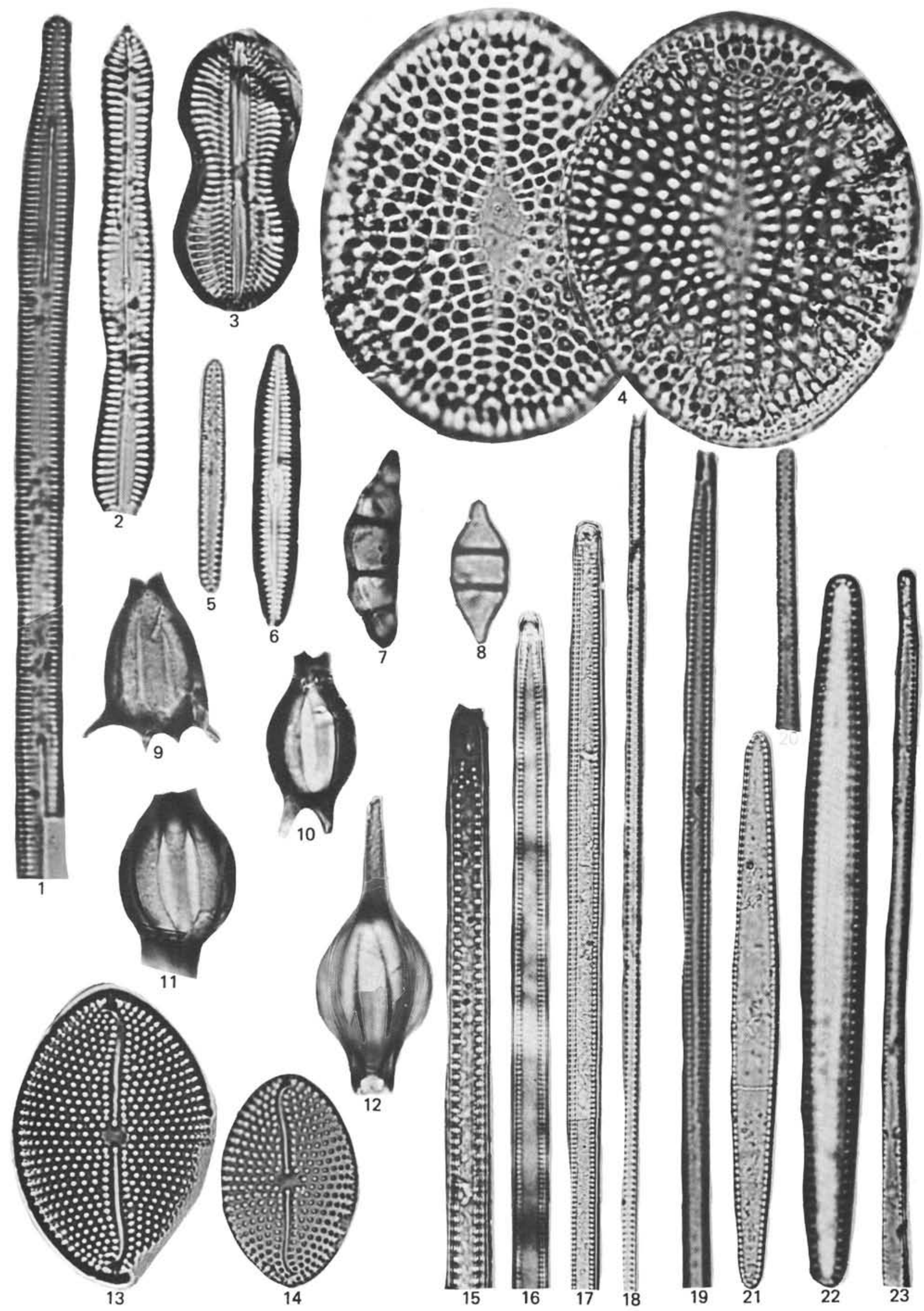


PLATE 34

Magnification 1500×, except Figure 31, 1200×

Figures 1,2 Cladogramma? cebuense Grunow in Van Heurck (1882).

1. Sample 356-8-2, 30-31 cm.

2. Sample 356-8-1, 51-52 cm.

Figures 3-5 Ceratophora sp. (1).

3. Sample 356-6-4, 30-31 cm.

4. Sample 356-6-2, 30-31 cm.

5. Sample 356-6-2, 30-31 cm.

Figure 6 Ceratophora sp. (2). Sample $356-6-4,30-31 \mathrm{~cm}$.

Figure 7 Chaetoceros sp. Sample 356-6-2, 30-31 cm.

Figure $8 \quad$ Chaetoceros sp. 1. Sample 356-8-2, 30-31 cm.

Figure 9 Chaetoceros sp. 2. Sample 356-8-1, $51-52 \mathrm{~cm}$.

Figure $10 \quad$ Chaetoceros sp. Sample 358-1-3, 30-31 cm.

Figure 11 Xanthiopyxis sp. B. Wornardt (1967). Sample 356-6-5, 30-31 cm.

Figure 12 Xanthiopyxis sp. 1 Hajós in Hajós and Stradner (1975). Sample 354-12-2, 14-15 cm.

Figures 13, 14 Xanthiopyxis sp. A Wornardt (1967).

13. Sample $356-7-2,30-31 \mathrm{~cm}$.

14. Sample $356-7-6,30-31 \mathrm{~cm}$.

Figure $15 \quad$ Xanthiopyxis umbonata Greville (1886). Sample 356-9-2, 30-31 cm.

Figures 16-18 Genus and species indet. (1).

16. Sample $354-12-5,82-83 \mathrm{~cm}$.

17. Sample $354-12-3,2-3 \mathrm{~cm}$.

18. Sample $354-12-5,82-83 \mathrm{~cm}$.

Figure 19 Genus and species indet. (4). Sample 356-8-1, 51-52 cm.

Figures 20,21 Dicladia sp. 2 Kanaya (1957).

20. Sample 356-9-2, 30-31 cm.

21. Sample $356-7-3,30-31 \mathrm{~cm}$.

Figure 22 Dicladia sp. I Kanaya (1957). Sample 356-6-5, 30-31 cm.

Figure 23 Resting spore. Sample 354-12-6, 137-138 cm.

Figures 24, 25 Liradiscus ovalis Greville (1865).

24. Sample 356-7-6, 30-31 cm.

25. Sample 356-6-4, 30-31 cm cm.

Figure $26 \quad$ Chaetoceros spore (a). Sample 356-7-4, 30-31 cm.

Figure 27 Resting spore. Sample 356-6-2, 30-31 cm.

Figure 28 Resting spore. Sample 356-6-2, 30-31 cm.

Figure 29 Chaetoceros spore. Sample 356-7-6, 30-31 cm.

Figure $30 \quad$ Chaetoceros spore (b). Sample $354-12-5,82-83 \mathrm{~cm}$.

Figure 31 Genus and species indet. Sample $356-9-2,30-31 \mathrm{~cm}, 1200 \times$.

Figure 32 Resting spore. Sample 356-9-2, 30-31 cm.

Figure 33 Resting spore (1). Sample 356-8-1, 51-52 cm.

Figure 34 Stephanogonia striolata Pantocsek (1889). Sample 356-6-2, 30-31 cm. 
PLATE 34

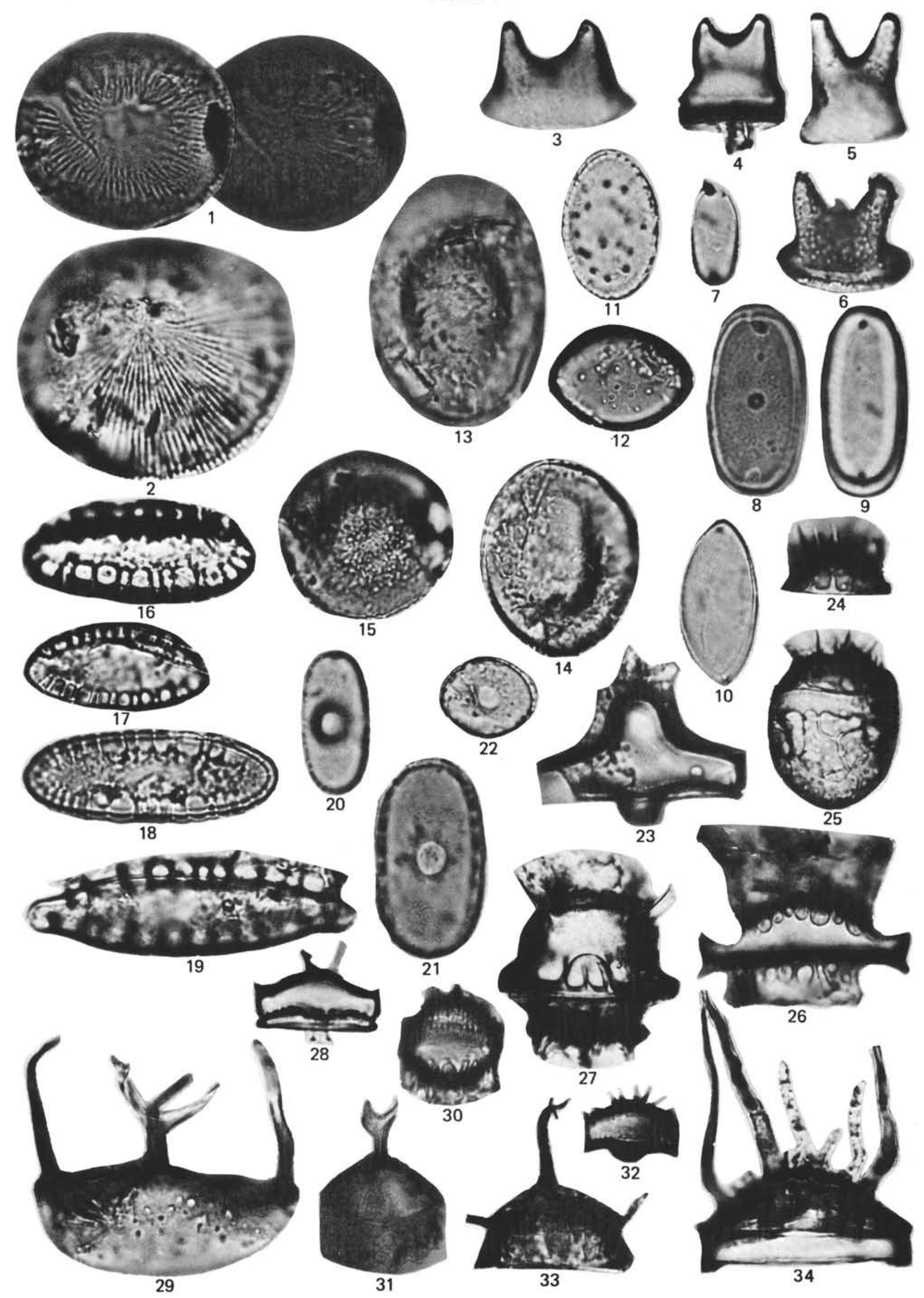


PLATE 35

Magnification $1500 \times$

Figure 1 Dicladia sp. 2 Kanaya (1957).

Sample 356-6-3, 30-31 cm.

Figures 2, $3 \quad$ Xanthiopyxis sp. 2.

2. Sample 356-6-4, 30-31 cm.

3. Sample $356-6-3,30-31 \mathrm{~cm}$.

Figures 4,5 Xanthiopyxis diaphana Forti (1910).

Sample 356-6-4, 30-31 cm.

Figure $6 \quad$ Xanthiopyxis sp. 1.

Sample 358-1-3, 30-31 cm.

Figures 7,8 Xanthiopyxis hirsuta Hanna et Grant (1926).

7. Sample 356-8-1, 51-52 cm.

8. Sample $356-9-2,30-31 \mathrm{~cm}$.

Figure 9 Xanthiopyxis oblonga Ehrenberg (1844).

Sample 354-12-2, 14-15 cm.

Figures 10-14 Xanthiopyxis sp. 3.

10. Sample $356-7-2,30-31 \mathrm{~cm}$.

11. Sample $356-7-3,30-31 \mathrm{~cm}$.

12. Sample 356-6-3, 30-31 cm.

13. Sample 356-6-2, 30-31 cm.

14. Sample $356-6-2,30-31 \mathrm{~cm}$.

Figures 15, 16 Xanthiopyxis sp. C Wornardt (1967).

15. Sample $356-8-1,51-52 \mathrm{~cm}$.

16. Sample $358-2-4,30-31 \mathrm{~cm}$.

Figure 17 Xanthiopyxis sp.

Sample 356-6-2, 30-31 cm.

Figure 18 Xanthiopyxis oblonga? Ehrenberg (1844).

Sample 356-6-3, 30-31 cm.

Figure $19 \quad$ Xanthiopyxis sp. 4.

Sample 354-12-2, 14-15 cm.

Figures 20-22 Xanthiopyxis ovalis Lohmann (1938).

20. Sample 356-7-6, 30-31 cm.

21. Sample 356-7-6, 30-31 cm.

22. Sample $354-12-2,14-15 \mathrm{~cm}$.

Figures 23, 24 Liradiscus bipolaris Lohmann (1938).

Sample 354-12-2, 14-15 cm.

Figures 25, 26 Xanthiopyxis acrolopha Forti (1912).

25. Sample 354-12-2, $14-15 \mathrm{~cm}$.

26. Sample $354-12-1,49-50 \mathrm{~cm}$. 
PLATE 35

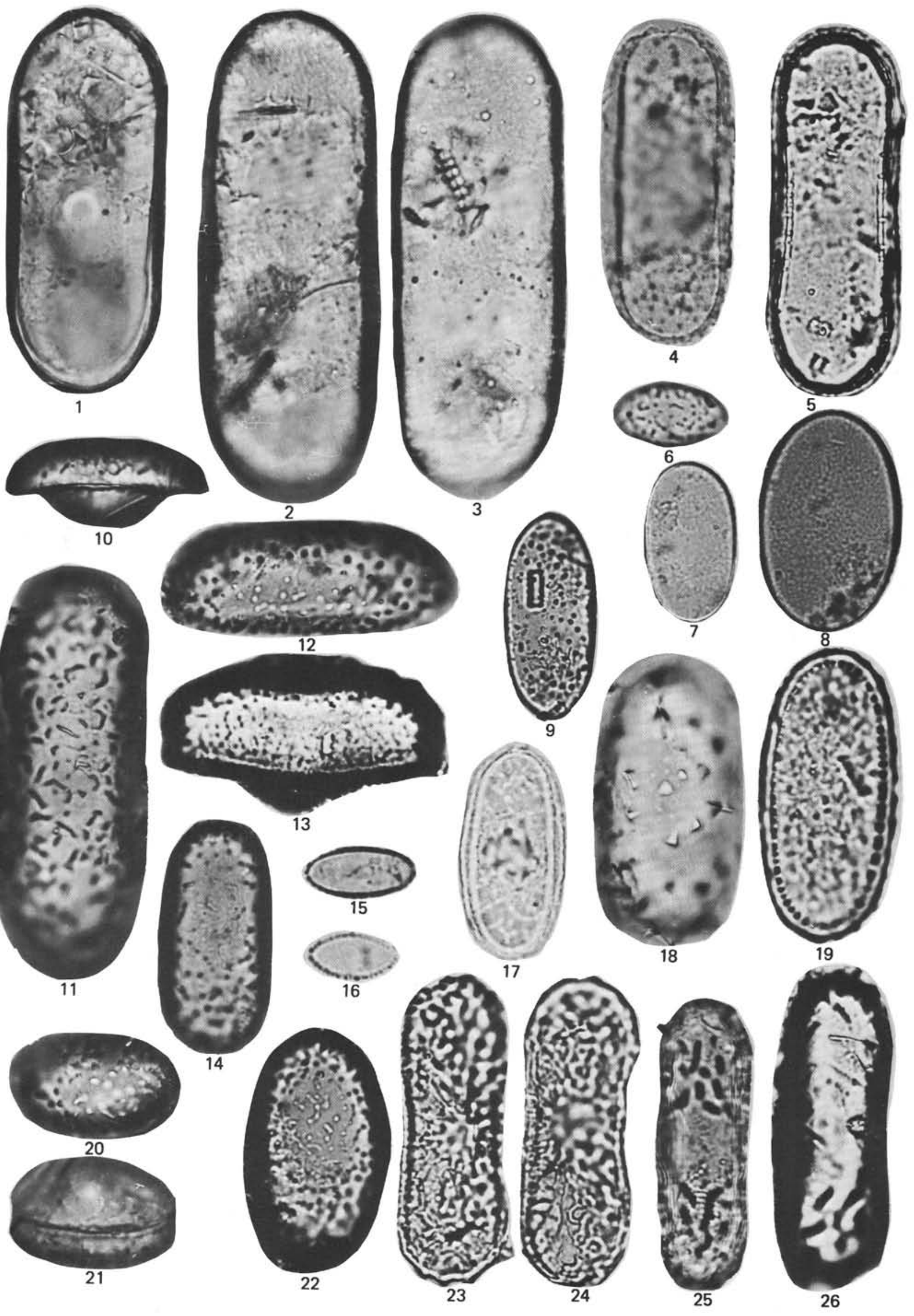


PLATE 36

Magnification $1500 \times$.

Figures 1, 2 Xanthiopyxis hystrix Forti (1913).

Sample 354-12-3, 2-3 cm (same specimen).

Figures 3, $4 \quad$ Xanthiopyxis sp. 4.

3. Sample 356-7-2, 30-31 cm.

4. Sample $356-6-4,30-31 \mathrm{~cm}$.

Figures 5,6 Xanthiopyxis sp. 5.

Sample 356-7-6, 30-31 cm (same specimen).

Figures 7, 8 Chaetoceros panduraeformis (Pantocsek) Gombos (in press).

7. Sample 356-7-6, 30-31 cm.

8. Sample 356-6-4, 30-31 cm.

Figures 9, 10 Xanthiopyxis sp. B Wornardt (1967).

9. Sample $356-7-5,30-31 \mathrm{~cm}$.

10. Sample $356-7-4,32-33 \mathrm{~cm}$.

Figure $11 \quad$ Xanthiopyxis sp. 3?

Sample 356-6-3, 30-31 cm.

Figure 12 Chaetoceros panduraeformis (Pantocsek) Gombos (in press).

Sample 356-9-2, 30-31 cm.

Figure 13 Genus and species indet.

Sample 356-7-4, 32-33 cm.

Figures 14-16 Genus and species indet. (6) Schrader and Fenner (in press b).

14. Sample 356-6-6, 30-31 cm.

15. Sample 356-6-4, 30-31 cm.

16. Sample $356-7-4,32-33 \mathrm{~cm}$. 
PLATE 36
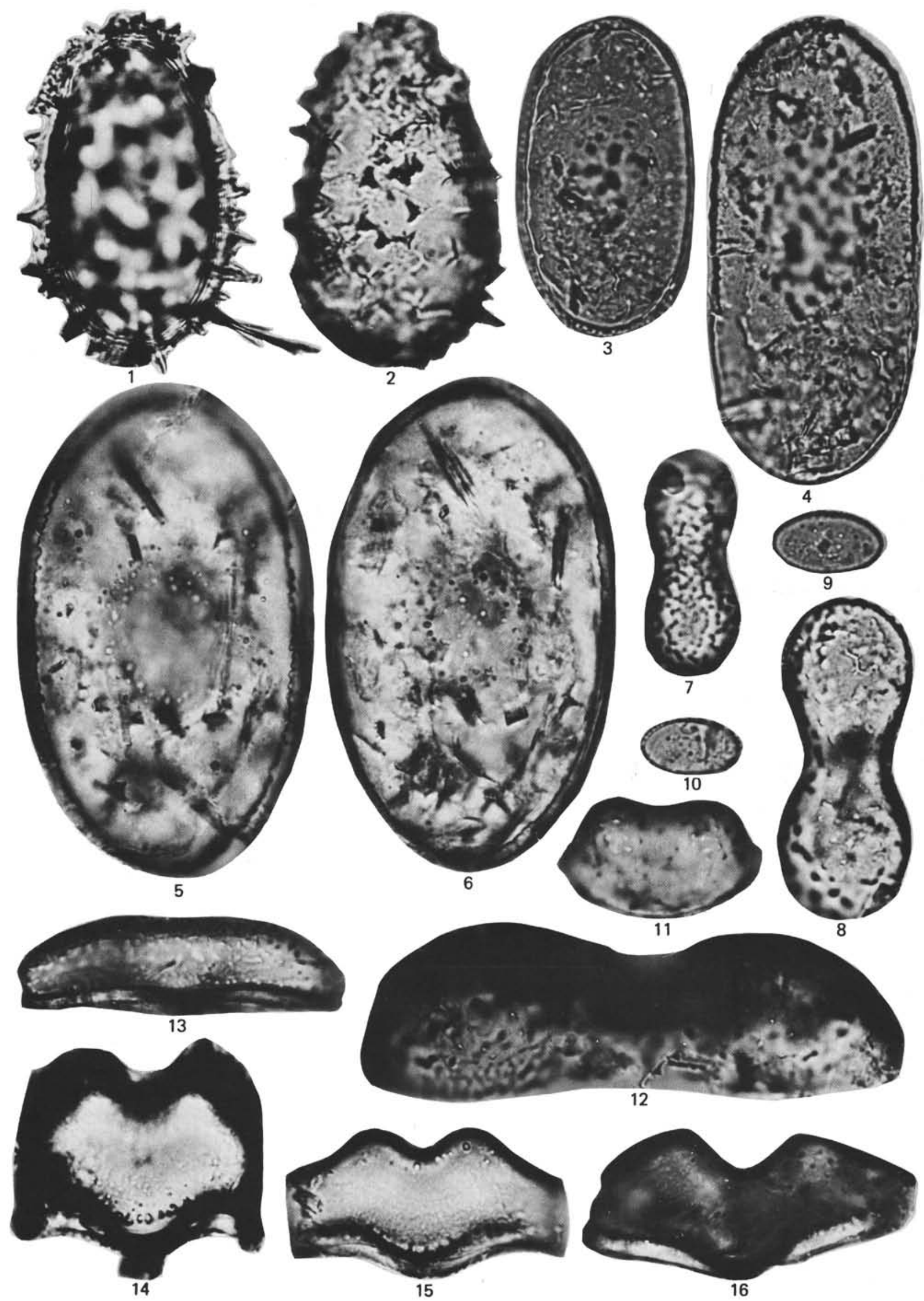


\section{PLATE 37}

Magnification 1500×, except Figures 6, 16: 750X;

Figure 19: 1200×; Figure 20: 1000×.

Figures 1,2 Xanthiopyxis globosa Ehrenberg (1844).

1. Sample $356-6-2,30-31 \mathrm{~cm}$.

2. Sample 354-12-6, 137-138 cm.

Figure 3 Triceratium schulzii? Jousé (1949).

Sample 356-9-2, 30-31 cm.

Figure $4 \quad$ Resting spore.

Sample 356-6-6, 30-31 cm.

Figure $5 \quad$ Resting spore.

Sample 356-6-2, 30-31 cm.

Figure $6 \quad$ Craspedodiscus aff. elegans Ehrenberg (1844).

Sample 356-8-1, 51-52 cm, 750X.

Figure $7 \quad$ Riedelia $\mathrm{sp}$

Sample 356-9-2, 30-31 cm.

Figure $8 \quad$ Chaetoceros spore (3).

Sample 356-7-4, $32-33 \mathrm{~cm}$.

Figure $9 \quad$ Resting spore.

Sample 356-9-2, 30-31 cm.

Figures 10,11 Stephanopyxis reticulata Long, Fuge and Smith (1946).

10. Sample 356-7-6, 30-31 cm.

11. Sample $354-12-6,40-41 \mathrm{~cm}$.

Figure $12 \quad$ Liradiscus sp. 1.

Sample 358-1-5, 30-31 cm.

Figures 13,14 Xanthiopyxis sp. (b).

13. Sample $354-12-2,14-15 \mathrm{~cm}$.

14. Sample $356-8-1,51-52 \mathrm{~cm}$.

Figure 15 Hemiaulus sp. 5.

Sample 356-9-2, 30-31 cm.

Figure 16 Coscinodiscus excavatus Greville var. quadriocellata Grunow (1884).

Sample 354-12-3, 2-3 cm, $750 \times$.

Figure 17 Riedelia claviger (A. Schmidt) Schrader and Fenner (in press).

Sample 356-7-5, $30-31 \mathrm{~cm}$.

Figure 18 Pyrgupyxis johnsoniana (Forti) Hendey (1969). Sample 356-7-4, 32-33 cm.

Figures 19, 20 Pyrgupyxis gracilis (Tempère and Forti) Hendey var. saratoviana (Pantocsek) Hendey (1969).

19. Sample 356-9-2, 30-31 cm, 1200x.

20. Sample $356-7-4,32-33 \mathrm{~cm}, 1000 \times$. 
PLATE 37

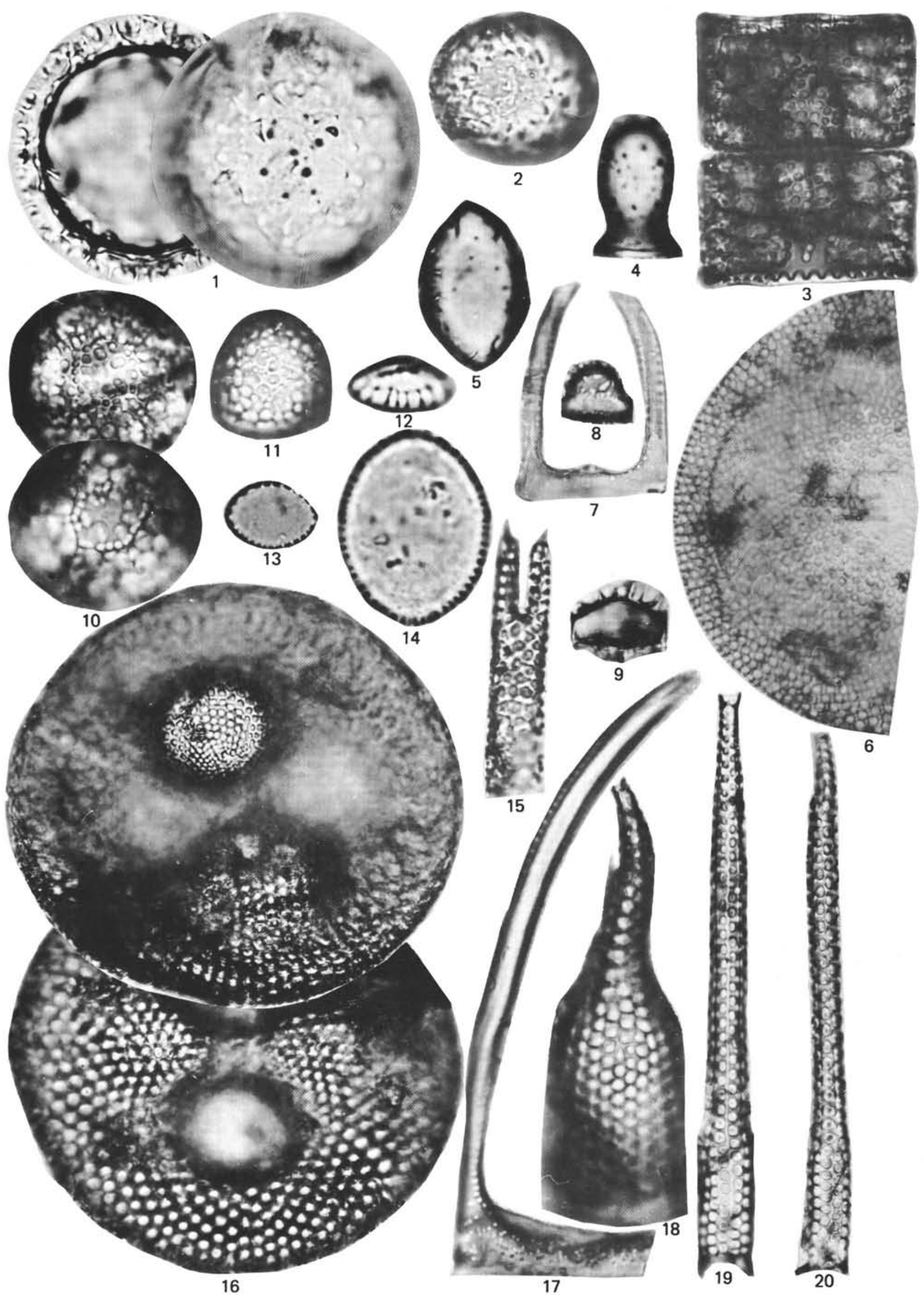


This table replaces Table 2 in Chapter 13 of Volume 39.

TABLE 2

Mineralogic Composition of Bottom Sediments From Leg 39 (light-mineral content, in per cent of fraction 0.1-0.05 mm)

\begin{tabular}{|c|c|c|c|c|c|c|c|c|c|c|c|c|c|c|}
\hline Hole & Core & Section & $\begin{array}{c}\text { Interval } \\
(\mathrm{cm})\end{array}$ & 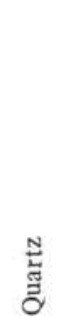 & 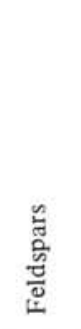 & 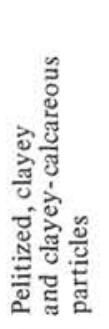 & 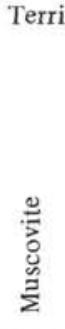 & 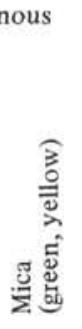 & 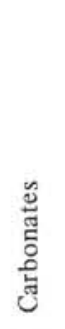 & 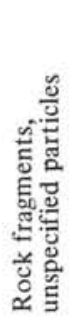 & Total & 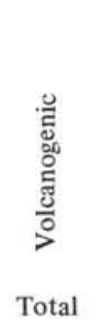 & 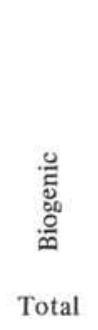 & 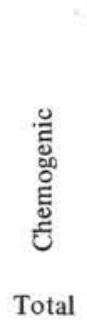 \\
\hline \multirow[t]{4}{*}{353} & 2 & 1 & $120-122$ & 4.8 & 4.4 & - & 6.9 & 8.2 & - & - & 24.3 & - & 75.4 & - \\
\hline & 3 & 2 & $4-5$ & 43.3 & 43.6 & 12.0 & - & 0.4 & - & - & 99.3 & - & 0.4 & 0.4 \\
\hline & 3 & 2 & $70-72$ & 50.4 & 42.9 & 6.4 & - & - & - & - & 99.7 & - & - & - \\
\hline & $\begin{array}{l}3 \\
3\end{array}$ & 2 & $130-132$ & 41.4 & 47.0 & 10.8 & - & 0.7 & - & - & 99.9 & - & 0.3 & - \\
\hline \multirow{2}{*}{$353 \mathrm{~A}$} & $\begin{array}{l}3 \\
1\end{array}$ & 2 & $145-147$ & 56.9 & 30.4 & 6.2 & - & 1.8 & - & - & 95.3 & - & 4.0 & - \\
\hline & $\begin{array}{l}1 \\
1\end{array}$ & 1 & $62-64$ & 53.4 & 28.0 & 9.8 & - & 0.7 & 0.5 & 0.7 & 93.1 & 0.8 & 6.2 & - \\
\hline \multirow{8}{*}{354} & 1 & $\frac{2}{2}$ & $\underset{55}{120-122}$ & $\begin{array}{r}26.2 \\
0.3\end{array}$ & 8.6 & 53.4 & - & - & - & - & 88.2 & - & 11.8 & - \\
\hline & 2 & 2 & $\begin{array}{l}55 \\
\mathrm{CC}\end{array}$ & 0.3 & $\overline{-}$ & $\overline{8.4}$ & $\bar{z}$ & $\overline{-}$ & - & $\overline{0.4}$ & $\begin{array}{l}0.3 \\
8.8\end{array}$ & $\bar{z}$ & $\begin{array}{l}99.7 \\
91.3\end{array}$ & \\
\hline & 3 & 2 & 120 & - & - & $\stackrel{0.4}{-}$ & - & - & - & - & 0.0 & - & 100.0 & $\overline{-}$ \\
\hline & 4 & 3 & 100 & - & - & - & - & - & - & - & - & - & 99.7 & $\overline{0.3}$ \\
\hline & 4 & 6 & 110 & - & - & 0.2 & - & - & - & - & 0.2 & - & 99.7 & - \\
\hline & 5 & 1 & $71-73$ & 0.3 & - & - & - & - & - & - & 0.3 & - & 99.7 & - \\
\hline & 6 & 3 & 104 & - & - & - & - & - & - & - & - & - & 100.0 & - \\
\hline & 7 & 4 & 137 & - & - & - & - & - & - & - & $\overline{-}$ & - & 100.0 & - \\
\hline \multirow[t]{4}{*}{355} & 1 & 4 & 73-75 & 5.7 & 54.4 & 3.9 & 0.4 & 3.5 & - & - & 67.9 & 0.9 & 29.5 & 1.7 \\
\hline & 1 & 5 & $60-62$ & 54.0 & 19.1 & 7.5 & 0.6 & $=$ & - & - & 81.2 & - & 18.2 & 0.6 \\
\hline & 1 & 6 & $80-82$ & 19.1 & 10.6 & 37.6 & 1.7 & 5.0 & 0.6 & - & 74.6 & 0.6 & 24.7 & - \\
\hline & 9 & 2 & $97-99$ & 0.3 & - & 89.5 & - & 0.3 & - & - & 90.1 & - & 8.3 & 1.3 \\
\hline \multirow{16}{*}{356} & 2 & 1 & $111-113$ & 0.7 & - & - & - & - & - & - & 0.7 & - & 99.3 & - \\
\hline & 3 & 2 & $15-17$ & 0.3 & 0.3 & 0.3 & - & - & - & - & 0.9 & - & 99.1 & - \\
\hline & 4 & 3 & $15-17$ & 0.3 & - & - & - & - & - & - & 0.3 & - & 99.7 & - \\
\hline & 5 & 4 & $50-53$ & 0.7 & 0.3 & 6.6 & 0.3 & 0.7 & - & - & 8.6 & - & 91.3 & - \\
\hline & 6 & 4 & $100-103$ & 0.3 & 0.6 & 8.6 & 0.3 & 0.3 & - & - & 10.1 & - & 89.6 & - \\
\hline & 7 & 4 & $40-43$ & 0.3 & - & 0.6 & - & 0.6 & - & - & 1.5 & - & 98.4 & - \\
\hline & 8 & 2 & $50-53$ & 0.3 & - & 19.9 & - & 0.7 & - & - & 20.9 & - & 78.9 & - \\
\hline & 9 & 2 & $108-110$ & - & - & 20.0 & - & - & - & - & 20.0 & - & 80.0 & - \\
\hline & 10 & 4 & $104-106$ & 1.6 & 1.6 & 5.5 & - & - & - & - & 8.7 & - & 90.9 & 0.3 \\
\hline & 11 & 2 & $13-17$ & - & 0.3 & 4.6 & - & - & - & - & 4.9 & - & 95.1 & - \\
\hline & 17 & 4 & $40-43$ & 0.9 & 1.5 & - & -. & - & - & - & 2.4 & - & 97.4 & 0.3 \\
\hline & 26 & 2 & $9-11$ & 0.6 & 0.3 & 0.3 & - & 1.0 & - & - & 2.2 & - & 97.7 & - \\
\hline & 29 & 2 & $100-102$ & 0.3 & - & 2.0 & - & - & - & - & 2.3 & - & 97.7 & - \\
\hline & 29 & 6 & $22-24$ & 1.0 & 1.6 & 0.3 & 1.3 & 1.0 & - & - & 5.2 & - & 94.7 & - \\
\hline & 31 & 5 & $87-89$ & 0.3 & 0.6 & 0.3 & 0.5 & - & - & - & 1.7 & - & 98.3 & - \\
\hline & 33 & 2 & $98-100$ & 1.6 & 1.2 & - & - & 0.3 & - & 0.6 & 3.7 & - & 93.8 & 2.3 \\
\hline \multirow{2}{*}{$356 \mathrm{~A}$} & 1 & 4 & $68-70$ & 2.2 & 0.6 & 0.3 & - & 0.6 & - & - & 3.7 & - & 96.1 & - \\
\hline & 2 & 5 & $40-42$ & 0.9 & - & - & - & - & - & - & 0.9 & - & 99.1 & - \\
\hline 357 & 1 & 2 & $123-126$ & 0.3 & - & - & - & - & - & - & 0.3 & - & 99.7 & - \\
\hline & 6 & 5 & $64-67$ & - & - & - & - & - & - & - & - & - & 100.0 & - \\
\hline & 8 & 4 & $50-53$ & - & - & - & - & - & - & - & - & - & 100.0 & - \\
\hline & 9 & 3 & $70-73$ & - & - & - & - & - & - & - & - & - & 100.0 & - \\
\hline & 13 & 5 & $84-87$ & - & - & 0.3 & - & - & - & - & 0.3 & - & 99.7 & - \\
\hline & 40 & 4 & $45-46$ & - & - & 88.1 & - & - & - & - & 88.1 & - & 12.0 & - \\
\hline & 41 & 2 & $79-80$ & - & - & 97.6 & 0.3 & - & - & - & 97.9 & - & 2.0 & - \\
\hline & 51 & 6 & $125-126$ & 0.7 & - & 83.2 & - & 0.3 & - & - & 84.2 & - & 13.9 & 2.0 \\
\hline 358 & 1 & 3 & $79-80$ & 3.1 & 0.3 & 50.0 & - & 1.0 & - & - & 54.4 & 7.6 & 37.8 & - \\
\hline & 3 & 2 & $75-77$ & 0.7 & 0.6 & 91.4 & - & 1.7 & - & - & 94.4 & 1.5 & 3.8 & 0.3 \\
\hline & 3 & 5 & $75-77$ & 1.0 & 5.0 & 32.8 & 0.3 & - & - & - & 39.1 & 0.7 & 60.2 & - \\
\hline & 4 & 1 & $108-110$ & 0.6 & - & 25.4 & 0.3 & 0.3 & - & - & 26.6 & 55.2 & 18.0 & - \\
\hline & 5 & 2 & $75-77$ & - & 0.4 & 50.9 & - & - & - & - & 51.3 & 17.3 & 31.4 & - \\
\hline & 6 & 2 & $124-126$ & 0.4 & - & 64.6 & - & - & - & - & 65.0 & 0.7 & 33.9 & 0.4 \\
\hline & 7 & 1 & $63-65$ & 0.4 & - & 35.0 & - & 0.8 & - & - & 36.2 & 1.4 & 62.6 & - \\
\hline & 8 & 1 & $121-123$ & 0.9 & 0.9 & 89.3 & 0.3 & 0.9 & - & - & 92.3 & 1.2 & 5.8 & 0.6 \\
\hline & 9 & 2 & $62-64$ & 1.0 & 0.6 & 79.5 & 0.3 & - & - & - & 81.4 & 0.3 & 16.5 & 1.6 \\
\hline & 10 & 3 & $72-74$ & 0.8 & 0.4 & 84.5 & 0.4 & - & - & - & 86.1 & - & 13.6 & 0.4 \\
\hline & 11 & 3 & $7-9$ & 0.3 & 0.7 & 1.7 & - & - & - & 1.0 & 3.7 & 0.3 & 95.9 & - \\
\hline & 11 & 4 & $91-93$ & 0.3 & - & - & - & - & - & - & 0.3 & - & 99.3 & 0.3 \\
\hline & 12 & 3 & $73-75$ & 0.4 & 0.7 & - & - & - & - & - & 1.1 & 0.4 & 98.6 & - \\
\hline & 12 & 4 & $63-65$ & 0.7 & 0.4 & 43.9 & - & 0.4 & - & - & 45.4 & - & 22.7 & 32.0 \\
\hline & 13 & 1 & $107-109$ & 0.4 & 0.3 & 82.6 & - & - & - & - & 83.3 & - & 15.4 & 1.0 \\
\hline & 14 & 2 & $136-138$ & - & - & 31.8 & - & - & - & 0.7 & 32.5 & - & 67.7 & - \\
\hline & 15 & 1 & $67-69$ & 6.5 & 0.6 & 71.3 & 1.0 & 0.6 & - & 7.5 & 87.5 & 0.4 & 8.9 & 3.0 \\
\hline & 16 & 2 & $99-101$ & 2.0 & 1.0 & 83.2 & - & 1.3 & - & 0.3 & 87.8 & - & 3.0 & 9.0 \\
\hline 359 & 1 & 3 & $52-54$ & - & - & - & - & - & - & - & - & - & 100.0 & - \\
\hline & 2 & 6 & $100-102$ & 1.7 & 1.0 & 11.4 & - & 0.7 & 0.3 & - & 15.4 & 0.3 & 84.0 & 0.7 \\
\hline & 3 & 1 & $94-96$ & 2.3 & 3.0 & 17.0 & - & - & - & 0.8 & 23.1 & 16.6 & 60.0 & 0.4 \\
\hline & 3 & 3 & $119-121$ & 1.0 & 9.1 & 55.4 & - & - & - & - & 65.5 & 26.0 & 8.4 & - \\
\hline & 3 & 4 & $43-45$ & 2.4 & 7.1 & 3.0 & - & 0.3 & - & - & 12.8 & 25.3 & 61.3 & 0.7 \\
\hline & 3 & 4 & $68-70$ & 0.3 & 13.6 & 13.9 & - & 3.0 & - & - & 30.8 & 66.2 & 3.0 & - \\
\hline & 3 & 5 & $79-81$ & 1.7 & 6.3 & 9.0 & - & 1.0 & - & - & 18.0 & 6.0 & 75.6 & 0.3 \\
\hline $359 \mathrm{~A}$ & 1 & 4 & $29-31$ & 0.3 & - & - & - & - & - & - & 0.3 & - & 99.7 & - \\
\hline & 2 & 5 & $111-113$ & - & - & - & - & - & - & - & - & - & 100.0 & - \\
\hline
\end{tabular}

